Andrews University

Digital Commons @ Andrews University

1988

\title{
Orthodoxy And Heresy In Hans Küng: An Analysis And Critique Of His Criteria And Norms Of Christian Truth And Error
}

C Enrique Espinosa

Andrews University

Follow this and additional works at: https://digitalcommons.andrews.edu/dissertations

Part of the Catholic Studies Commons, Christianity Commons, and the Religious Thought, Theology and Philosophy of Religion Commons

\section{Recommended Citation}

Espinosa, C Enrique, "Orthodoxy And Heresy In Hans Küng: An Analysis And Critique Of His Criteria And Norms Of Christian Truth And Error" (1988). Dissertations. 46.

https://digitalcommons.andrews.edu/dissertations/46

https://dx.doi.org/10.32597/dissertations/46

This Dissertation is brought to you for free and open access by the Graduate Research at Digital Commons @ Andrews University. It has been accepted for inclusion in Dissertations by an authorized administrator of Digital Commons@ Andrews University. For more information, please contact repository@andrews.edu. 


\section{INFORMATION TO USERS}

The most advanced technology has been used to photograph and reproduce this manuscript from the microfilm master. UMI films the text directly from the original or copy submitted. Thus, some thesis and dissertation copies are in typewriter face, while others may be from any type of computer printer.

The quality of this reproduction is dependent upon the quality of the copy silbmitted. Broken or indistinct print, colored or poor quality illustrations and photographs, print bleedthrough, substandard margins, and improper alignment can adversely affect reproduction.

In the unlikely event that the author did not send UMI a complete manuscript and there are missing pages, these will be noted. Also, if unauthorized copyright material had to be removed, a note will indicate the deletion.

Oversize materials (e.g., maps, drawings, charts) are reproduced by sectioning the original, beginning at the upiser left-hand corner and continuing from left to right in equal sections with small overlaps. Each original is also photographed in one exposure and is included in reduced form at the back of the book. These are also available as one exposure on a stancard $35 \mathrm{~mm}$ slide or as a $17^{\prime \prime} \times 23^{\prime \prime}$ black and white photographic print foi an additional charge.

Photographs included in the original manuscript nave been reproduced xerographically in this copy. Higher quality $6^{\prime \prime} \times 9^{\prime \prime}$ black and white photographic prints are available for any photographs or illustrations appearing in this copy for an additional charge. Contact UMI directly to order.

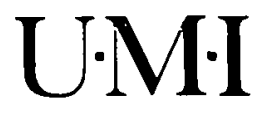

University Microfims Iriternatıonal

A Bell \& Howell Information Company

300 North Zeeb Road. Ann Arbor. MI 48106-1346 USA

$313 / 761-4700 \quad 800,521.0600$ 
Order Number 8919898

Orthodoxy and heresy in Hans Küng: An analysis and critique of his criteria and norms of Christian trutî̀ and error

Espinosa. Carlos Enrique, Ph.D.

Andrews University, 1988

Copyright (C)1988 by Espinosa, Carlos Enrique. All rights reserved.

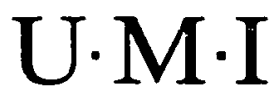

300 N. Zceb Rd.

Ann Asbor, MI 48106 


\author{
Andrews University \\ Seventh-day Adventist Theological Seminary
}

\begin{abstract}
ORTHODOXY AND HERESY IN HANS KUTNG:
AN ANALYSIS AND CRITIQUE OF HIS

CRITERIA AND NORMS OF CHRISTIAN

TRUTH AND ERROR
\end{abstract}

\author{
A Dissertation \\ Presented in Partial Fulfillment \\ of the Requirements for the Degree \\ Doctor of Philosophy
}

by

C. Enrique Espinosa

February 1988

Reproduced with permission of the copyright owner. Further reproduction prohibited without permission. 


\section{ORTHODOXY AND HERESY IN HANS KÜNG: \\ AN ANALYSIS AND CRITIQUE OF HIS CRITERIA AND NORMS OF CHRISTIAN TRUTH AND ERROR}

A dissertation

presented in partial fulfillment

of the requirements for the degree

Doctor of Philosophy

\section{by}

C. Enrique Espinosa

\PPROVAL BY THE COMMITTEE:
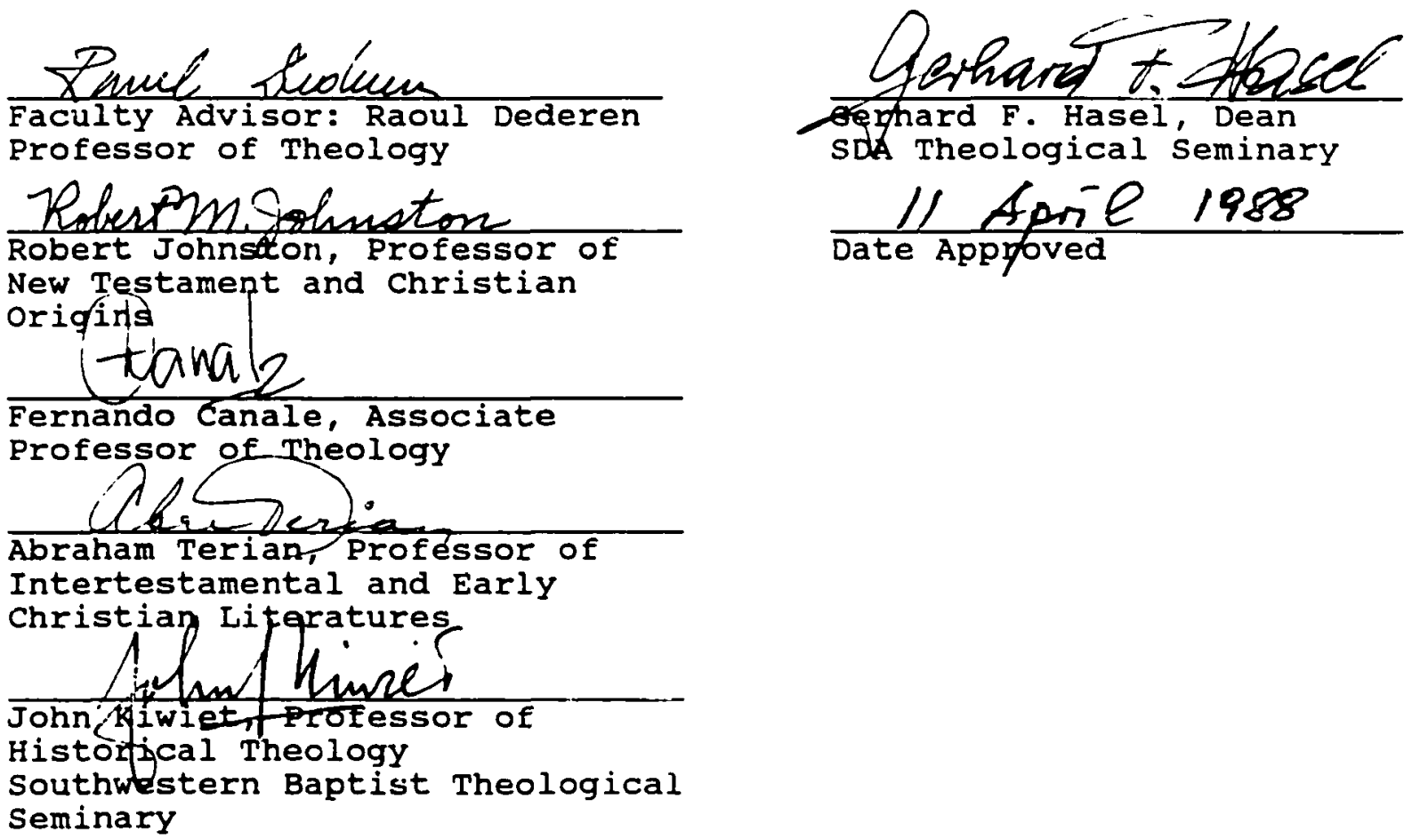

Reproduced with permission of the copyright owner. Further reproduction prohibited without permission. 
(C) Copyright by C. Enrique Espinosa 1988

.11l Rights Reservel

Reproduced with permission of the copyright owner. Further reproduction prohibited without permission. 


\section{ABSTRACT \\ ORTHODOXY AND HERESY IN HANS KÜNG: AN ANALYSIS AND CRITIQUE OF HIS CRITERIA AND NORMS OF CHRISTIAN TRUTH AND ERROR}

by

C. Enrique Espinosa

Chairman: Raoul Dederen

Reproduced with permission of the copyright owner. Further reproduction prohibited without permission. 


\author{
ABSTRACT OF GRADUATE STUDENT RESEARCH \\ Dissertation \\ Andrews University \\ Seventh-day Adventist Theological Seminary
}

\begin{abstract}
Title: ORTHODOXY AND LIERESY IN HANS KÜNG: AN ANALYSIS AND CRITIQUE OF HIS CRITERIA AND NORMS OF CHRISTIAN TRUTH AND ERROR

Name of researcher: C. Enrique Espinosa

Name and degree of faculty adviser: Raoul Dederen, Dr. es Sc.Morales Date completed: February 1988.
\end{abstract}

This investigation deals with the concepts of orthodoxy and heresy in the thought of the Swiss theologian Hans Küng.

Chapter I sketches the broad outlines of the development of Christian orthodoxy and, by implication, of the heresy which opposed it, státiing with the New Testament times. The most relevant elements constituting the structure of the orthodoxy-heresy antithesis ara identified, described, and analyzed. The attention is thus focused on the traditional and modern principles, criteria, norms, and theological issues which have interplayed in the church's efforts to understand the Christian message correctly. Chapter II shows that the pastoral concerns which constitute King's theological starting point originated during the years of his 1 
priestly formation in Rome. These concerns are his interest in contributing to the ecumenical understanding among all Christian traditions and his preoccupation for proclaiming the gospel in terms both intelligible and relevant to modern humankind. Some important shifts in the development of Küng's theology and his hermeneutical principies ace described as wel?.

Chapter II endeavors to describe and analyze Küng's understanding of the principles, criteria, and norms of classical orthodoxy. It presents the manner in which the Swiss theologian stresses the normativity of the original deposit of faith over against the sub-apostolic traditions and magisterial pronouncements of the church. Küng's concept of heresy as a selection from the totality of revelation is addressed at the end of the chapter.

Chapter IV deals with the modern criteria and norms of orthodoxy. Küng's dynamic, dialectical, and historical concept of truth as such is described and analyzed. In this context, his $\because$ lews on the fallibility of huran propositions are also addressed. Küng's theory of the changes of paradigm in theology is briefly enunciated. This theory explains how the revolutionary changes in the basic assumptions and in the world-view of one paradigm originate a crisis which entails the replacement of the old paradigm by the new, thus turning past orthedoxies obsolete.

This study ends, in chapter $V$, with a critical appraisal of Küng's model of orthodoxy-heresy. It is concluded that his decisive norm of Christian truth is the modern scientifir-historicist horizon of understanding. As for the gospel of Jesus Christ, whicil Küng 
claims is his ultimate criterion and norm of Christian truth, it is considered, rather, as the center of the theologian's personal faith. Finally, some of the contributlons of küng to the undetstanding of orthodoxy-heresy are mentioned, 35 well as the inner censions of his model. 
To Lilian, my baloved wife, and to our son Andrés 
TABLE OF CONTENTS

LIST OF ABBREVIATIONS . . . . . . . . . . . . . . . . . . vii

ACKNOWLEDGMENTS . . . . . . . . . . . . . . . . . . . . . $\mathbf{x}$

INTRODUCTION . . . . . . . . . . . . . . . . . . . . . . . . . . . . . . 1

Chapter

I. BACKGROUND TO THE QUERY . . . . . . . . . . . . . . . . . 18

Introductory Considerations . . . . . . . . . . . . 18

The Components of the Orthodoxy-Heresy Antithesis: Principles, Criteria, Norms, and Issues . . . . 19

Basic Constants in the Orthodoxy-Heresy Antithesis... . . . . . . . . . . . . . . 22

Orthodoxy and Heresy in the Ante-Nicene Church . . . 28

The Principle of Authcrity and the Revelational

Criterion of Orthodoxy . . . . . . . . . . . . 31

The teach: ig of the ano:tles as a norm of orthodoxy . . . . . . . . . . . . . . . . . 38

The New Testament Canon as a norm of orthocioxy . . . . . . . . . . . . . . . . 43

The Principle of Tradition and the Ecclesiastical Criterion of Orthodoxy . . . . . 50

Oral tradition as norm or orthodoxy . . . . . . 55

The pronouncements of the Magisterium as a norm of orthodoxy ............ . . 59

Orthodoxy and Heresy in the Post-Nicene

and Medieval Church . . . . . . . . . . . . . . . 64

The Issue of the Unity of the Church and Its Doctrine . . . . . . . . . . . . . . . 65

The Emergence of the Issue of Infallibility . . . 69

Orthodoxy and Heresy at the Time of the Protestant

Reformation and After . . . . . . . . . . . . . . 74

Infallibility and the Truth of the Christian Doctrine . . . . . . . . . . . . . . 77

ine Catholic and the Protestant 78

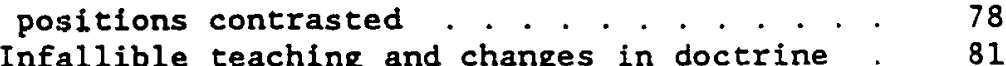

The Issue of Continuity and Change

in Christian Doctrine . . . . . . . . . . . . . 84

Orthodoxy-Heresy and the New Hermeneutical

Criterion . . . . . . . . . . . . . . . . . . 96

The historical way of thinking as a norm of orthodoxy............. . 102

iv 
Orthodoxy and heresy: the present state of the question . . . . . . . . . . 108

Summary and Conclusion . . . . . . . . . . . . . . 111

II. HANS KÜNG, THE THEOLOGIAN . . . . . . . . . . . . . . . 116

Küng's Pastoral Vocation . . . . . . . . . . . . . 118

Küng': Pastoral and Theological Concerns . . . . . . 121

The Starting Point of Küng's Theology . . . . . . . 124

At the Core of Küng Pastoral and

Theological Concerns.. . . . . . . . . . . . 127

Issues of a disciplinary nature . . . . . . . . . 128

Issues of a theological nature......... . . 130

Some Important Shifts in Küng's Theology . . . . . . 135

From intra-church themes to general ones... . . 136

A change in his view of the Scriptures. . . . . . 137

A change of theological perspective . . . . . . . 141

The motivations of Küng's shifts... . . . . . . 143

Küng's Hermeneutical Principles . . . . . . . . . . 146

III. THE CRITERIA AND NORMS OF CLASSICAL ORTHODOXY . . . . 153

Part One: On the Principles and Norms Related to the Revelational Criterion of Orthodoxy-Heresy . . 156

Küng's Understanding of the Principle

of Authority . . . . . . . . . . . . . . . . . . 157

The critique of the Roman Catholic model

of authorsty. . . . . . . . . . . . . . . 157

Küng's critique in historical context: The early years up to 1962 . . . . . . . . . . . . 165

Kün's critique at the time of Vatican II and after . . . . . . . . . . . . . . . 172

Revelation as a Criterion of Orthodoxy . . . . . . 178

The Teaching of the Apostles as a Norm of Orthodoxy. . . . . . . . . . . . . . . . . . 184

The Canon of the New Testament as a Norm of Orthodoxy . . . . . . . . . . . . . . . . . . 188

Part Two: On the Principles, Norms and Issues

Related to the Ecclesiastical Criterion

of Orthodoxy-Horesy . . . . . . . . . . . . . . . 201

The Principle of Succession-'iradition . . . . . . 204

The original point of reference for

Christian tradition . . . . . . . . . . . . 209

The historical dynamism of Christian tradition . 210

The issue of continuity-and-change

in Christian doctrine . . . . . . . . . . . . 212

The Normativity of the Magisterium's

Pronouncements................. . 217

The ::elationship theologians-Magisterium . . . . 224

Differing views on apostolic succession . . . . 228

The Unity of the Doctrines of the Church . . . . . 235

The Roman Catholic position on heresy . . . . . 237 
Küng's concept of heresy . . . . . . . . . . . . 239

Summary and Conclusion. . . . . . . . . . . . . 248

IV. MODERN CRITERIA AND NORMS OF ORTHODOXY . . . . . . . . 257

Part One: On the Issues of Truth and Infallibility . 259

Main Philosophical Theories of Truth. . . . . . . 261

The correspondence theory . . . . . . . . . . 262

The coherence theory . . . . . . . . . . . . . 265

Two Dimensions of Truth . . . . . . . . . . . . . 257

Truth in the Scriptures . . . . . . . . . . . . 269

Küng's Concept of Truth and Infallibility . . . . 274

Truth as a quality of being: The personal

dimension of truth ............... . 276

Truth as propositional: The cognitive

dimension of truth . . . . . . . . . . . . . 281

Truth is dynamic: The fallibility

of propositions . . . . . . . . . . . . . . . 289

Truth lies in the total not in particulars.. . 298

Truth is historically relative. . . . . . . . . 300

Truth is dialectical . . . . . . . . . . . . 305

The complexity and unity of truth and tciitey. 309

Part Two: On Christian Truth in a New Paradigm . . 315

Truth, God, and Revelation . . . . . . . . . . . 317

The modern understanding of God . . . . . . . . 318

The Hellenistic and the modern historicist

views compared... . . . . . . . . . . 323

The rature of revelation. . . . . . . . . . . . 335

"Paradj gmenwechsel" in Theology . . . . . . . . . 339

Paradigm-change in the natural sciences . . . . 342

ineology and changes in the world-picture . . 347

V. SUMMARY, CRITIQUE, AND CONCLUSION . . . . . . . . . . 358

The Structure of the Orthodoxy-Herasy Antithesis. . 359

Küng's Criteria and Norms of Christian Truth:

A Review . . . . . . . . . . . . . . . . . . . . 369

The Traditional Criteria and Norms of orthodoxy . 373

The Criterion and the Norm of Truth in

a Modern Perspective... . . . . . . . . . . . 380

Küng's Criteria and Norms of Christian Truth:

A Cri que . . . . . . . . . . . . . . . . 388

Selective? An Inquiry . . . . . . . . . . . . . . 391

The Changes of Paradigm in Theology:

An Assessment . . . . . . . . . . . . . . . . . 405

Küng's Most Relevant Contributions to the

Understanding of Orthodoxy-heresy. . . . . . . . 417

Final Considerations . . . . . . . . . . . . . . . 421

SELECTED BIBLIOGRAPHY . . . . . . . . . . . . . . . . . . . . 429

$\mathbf{v i}$ 


\section{ABBREVIATIONS}

\begin{tabular}{|c|c|c|}
\hline AmER & -- & American Evangelicai Review \\
\hline ANF & -- & Ante-Nicene Fathers \\
\hline BDT & $\cdots$ & Daker's victionary of Theology \\
\hline Cathenc & -- & The Catholic Encyclopedia \\
\hline$\underline{\mathrm{CCL}}, 1963$ & $\cdots$ & Code of Canon Law, ed. 1963 \\
\hline CCL, 1983 & -- & Code of Canon Law, ed. 1983 \\
\hline CDF & $\cdots$ & Congregation for the Doctrine of the Faith \\
\hline ChOR & $\cdots$ & The Church Quarterly Review \\
\hline$\underline{\mathrm{CC}}$ & - & Christian Century \\
\hline Denz. & $-\cdot$ & Heinrich Denzinger, Enchiridion Symbolorum \\
\hline DSD & -- & Dictionnaire de spiritualité \\
\hline DTheol & -- & Dictionary of Theology \\
\hline ERel & -- & The Encyclopedia of Relizion \\
\hline Greg & $\cdots$ & Gregorianum \\
\hline HTR & -- & Harvard Theological Review \\
\hline HerdCor & - & Herder Correspondence \\
\hline HompastR & $\cdots$ & Homiletical and Pastoral Review \\
\hline IDB & $\cdots$ & The Interpreter's Dictionary of the Bible \\
\hline Int & $\cdots$ & Interpretation \\
\hline ITO & -- & Irish Theological Quarterly \\
\hline JEVTS & $\cdots$ & Journal of the Evangelical Theological Society \\
\hline JRel & $\cdots$ & The Journal of Religion \\
\hline
\end{tabular}

vii 


\begin{tabular}{|c|c|c|}
\hline KerDo & $\cdots$ & Kerygma und Dogma \\
\hline LCC & -- & Library of Christian Classics \\
\hline LIK & $-\cdot$ & Lexikon für Theologie und kirche \\
\hline NCathEnc & -- & New Catholic Encyclopedia \\
\hline NIDNTT & -- & New International Dictionary of New Testament \\
\hline NSchHerERK & $\cdots$ & $\begin{array}{l}\text { Theology } \\
\text { New Schaff-Herzog Encyclopedia of Religious } \\
\text { Knowledge }\end{array}$ \\
\hline QED & $\cdots$ & The Oxford English Dictionary \\
\hline$\underline{\mathrm{PG}}$ & $-\cdot$ & $\begin{array}{l}\text { J.-P. Migne, Patrologiae cursus completus. Series } \\
\text { graeca }\end{array}$ \\
\hline$\underline{\text { PL }}$ & -- & $\begin{array}{l}\text { J.-P. Migne, Patrologiae cursus completus. Series } \\
\text { latina }\end{array}$ \\
\hline Popesp & $\cdots$ & The Pope Speaks: The Church Documents Quarterly \\
\hline$\underline{\text { RelsRev }}$ & $\cdots$ & Religious Studies Review \\
\hline RevScRel & $\cdots$ & Revue des sclences religieuses \\
\hline RevExp & $\cdots$ & Review and Expositor \\
\hline RivstoChIt & $\cdots$ & Rivista di storla della Chiesa in Iralia \\
\hline$\underline{\text { SJT }}$ & $-\cdot$ & Scotish journal of Theology \\
\hline$\underline{\text { SM }}$ & $-\cdot$ & Sacramentum Mundi \\
\hline$\underline{\text { setzt }}$ & $-\cdot$ & Stimmen der zeit \\
\hline TDNT & $\cdots$ & Theulogical Dictionafy of the New Testament \\
\hline IDOT & $\cdots$ & Theological Dictionary of the 01d Testament \\
\hline IO & $\cdots$ & Theologische Ousctalschrift \\
\hline$\underline{\text { TS }}$ & $-\cdot$ & Theological Studies \\
\hline ISFBul & -- & ISF Bulletin \\
\hline
\end{tabular}

viii 
- Texte und Untersuchungen zur Geschichte der altchristlichen Literatur

VerDom $\quad \cdots \quad$ Verbum Domini

Wị

-. Hermann Häring and Karl-Josef Kuschel, Hans Küng: His Work and His Way

ZKKG -. Zeitschrift für Kirchengeschichte 


\section{ACKNOWLEDGMENTS}

It is well known to all those who have written a dectoral dissertation that the latter is the end-product of a long process of academic training. As in all processes, also in the education of a person the starting point is of key importance. For this reason, my first words of gratitude go to my teachers of the elementary and high schools in Chile. To them and to the generations of educators in that developing nation who have made possible for her to have a system of education comparable in quality to the so-called first world, my sincere recognizement. My thanks also go to my instructors, at undergraduate and graduate levels, of the School of Theology at the Instituto Profesional Adventista de Chile, and of the Latin American Seventh-day Adventist Theological Seminary. During my doctoral studies at Andrews University in Berrien Springs, Michigan, many individuals, too many indeed to mention all by name, have contributed to my work. I appreciate the helping hand in matters linguistic of my colleagues Werner Dullinger, Daniel Heinz, Bruce Norman, Ray Roennfeldt, and Michael Walter. Special thanks go to Ms. Doris Helm, Dr. Marley Soper, and Ms. Rebecca Twomley of the James White Library at Andrews University for the way in which they facilisated my research. Ms. Joyce Jones deserves also my gratitude for her editorial help and proofreading. Two professors of the Seventh-day Adventist Theological Seminary at Andrews University, besides the members of my doctoral committee, 
provided me with helpful insights through their lectures and seminars: to Drs. Fritz Guy and Miroslav Kis I express my gratitude. I an particularly grateful to the three members of $\bar{u}$ ü disseitation committee: to Dr. Robert if. Johnston who stimulated my reflection through his timely criticism and important suggestions especially on the section dealing with early Christianity; to Dr. Fernando Canale who provided valuable orientation and who spent long hours patiently discussing with me, especially those aspects related with the logicai and philosophical dimensions involved in the research; and to Dr. Raoul Dederen, the chairman of my committee, in whose office the project took shape and came to its final form. To Dr. Dederen I express my deep graticude for his wise advice and guidance, for his time-consuming work of assistance and scholarly criticism as well as for his words of encouragement in difficult moments, for his patience with my shortcomings, and for his Christian friendship.

I am indebted to the Instituto Profesional Adventista de Chile (known in the U.S. as Chile Union College) and the South American Division of the Seventh-day Adventist Church which provided the financial support for my doctoral training.

I have no words to express my gratitude to my wife who helped me and supported my work in many ways while she was herself studying toward her master's degree in Biblical and Ancient Languages. Also to my son Andres for the time which I should have spent with him and that I spent rather at the Library, and to my mother, who left her beloved Chile for two years and sacrificed her emotional and physical health in order to help us to take care of $\mathbf{x i}$ 


\begin{abstract}
Andrés, her grandson, who came to the U.S. being a baby of months. Finally, but above all things. I express my gratitude to God my Father and to Jesus Christ my Redeemer, for without their power and grace nothing would exist and nothing would be accomplished.
\end{abstract}




\section{INTRODUCTION}

The right to dissent ${ }^{1}$ in ideological, non-scientrític crrcies has been a controversial issue in the past and continues to be so today. tri.1: some political systems, for instance, accept dissent as a normal and even conventent feature of any social group, others regard it as subversive. The issue of this dissertation falls in the field of religion and, more specifically, of theology. ${ }^{2}$ Titerefore, its interest is in theological dissent.

Theological dissent must be distinguished from religious dissidence. 3 The term "cissent" may express either withholding of agreement or open disagreement, whereas "dissider:ce" suggests strong dissatisfaction as well as a determined opposilion. ${ }^{4}$ Thus, the soncern of this dissertation with theological dissent means that I

$1_{\text {To dissent means basically to disagree. Dictionaries }}$ explain that to dissent is to differ in sentiment or opinion. especially from the mafority (see, for instance, The Random House Dictionary of the English Language; Webster's New World Dictionary; and Encyclopaedia Britannica).

${ }^{2}$ As a basic differentiation between religion and theology, I must underline the intellectual nature of the latter over against the existential character of religion. Religion has to do with the way in which our total life is conducted in relation to the Supreme Being (it has to do with "how" we live), while theology provides the doctrinal basis for religious life (it has to do with "what" we belifve).

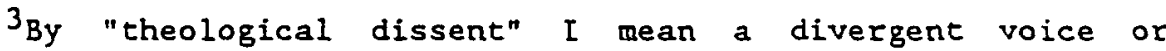
different opinion regarding the approved position of the church on a particular issue or doctrine.

${ }^{4}$ So most dict ionaries. 
do not deal with the problem posed by those Christians who develop a stubborn opposition to the churchl--which usually involves both a feeling and an attitude of enmity toward it--bui with the problem posed by those who think critically and voice their doubts and objections to some speciflc views of the majority in the church ${ }^{2}-a^{-a n}$ attitude which usually responds to the dissenter's concern for improving the understanding of the church for Christian truth. Dissenters are regarded as heretics ${ }^{3}$ when they question the officially defined teaching of the chirch.

The distinction between rruth and error in Christian doctrine is the issue which stands behind the orthodoxy-heresy antithesis. Moreover, the observation that in their doctrinal corilsuvessies linroughout church history all parties have tended to consider their own position as the true one while deeming the view of others as false, points to an issue that is at the very core of

$1_{\text {Here }}$ and in the rest of this Introduction $I$ am using the term "church" in iss wider meaning of the community of Christian believers with no particular denomination or ecclesiastical rank in mind.

2It cannot be said that those who think critically are always "liberals" countered by a more conservative majority or by conservative authortties. Sometimes "conservatives" dissent from a comparatively progressive majority whose position is endorsed by the church's teaching authority. The position of bishop Marcel Lefebvre may be considered an example of a conservative dissenter among Roman Catholics.

${ }^{3}$ For a definition of heresy and the heretic, see below, FP. 28-30, especially p. 29, n. 1. For the understanding of heresy from a Roman Cathollc perspective, see below, pp. 237-38. As a basic working definition, the heretic can be considered as the individual who, claiming to be right in his doctrinal position and wishing to remain in the community of faith, holds false belief in the eyes of the teaching authority of the church. 
the orthodoxy-heresy antithesis. In this context, the problem arises as to the cricerion (or criteria) by which each party defines the truth of its position, a problem which deserves special attention in this research.

Further consideration of the issue of theological dissent indicates that it is appreciated today among Christians from at least two different perspectives. Those who either on a historical or ideological basis hold that doctrinal pluralism is of the essence of Christianity affirm chat dissen= is nos only legitimate but natural. Some go so far as to hold that heresy is today an inappropriate concept. ${ }^{1}$ According to this view, what we have, rather than false teachings, are merely different approaches to the message of the church. ${ }^{2}$ on the sther hand, those who stress the need to take serfously the confession of their churches do not merely believe that heretics still exist, they also hold that heretics must be disciplined. ${ }^{3}$ For them heresy is a relevant category.

lFor instance, Walter Bauer in his orthodoxy and Heresy in Earliest Christlanity, ed. Robert A. Kraft and Gerhard Krodel, with appendices by Georg Stre-ker. trans. by a team from the Philadelphia Seminar on Christian Origins (Philadelphia: Fortress Press, 1971); and John Macquarrie, Thinking About God (New York: Harper and Row, 1975), P. 44 .

2 This moves Vittorio Messori, a Roman Catholic author, to remark that notions such as "heresy" and "heretic" sound so strange to cur modern ears that "they must be placed in quotation marks. When they are pronounced or written, one feels that one has been transported to times long past" (see Joseph Cardinal Ratzinger with Vittorio Messori, The Ratzinger Report: An Exclusive Interview on the State of the Church, trans. Salvator Attanasio and Graham Harrison [San Francisco: Ignatius Press, 1985], p. 24).

${ }^{3}$ See, for instance, Ratzinger and Messori, Ratzinger Report. p. 24; and I. Howard Marshall, "Orthodoxy and Heresy in Earlier Christianity," Themelios 2 (1976): 14 . 


\section{Importance of the Issue}

The controversy between a pluralist and a confessional view of Christian truth just hinted at is an issue of current theological interest. 1 Furthermore, doctrine and the search for Christian truth have occupied, undenfably, a signiflcant place in the history of theology and the church. In spite of the stress currently laid in some quarters upon orthopra::s over against c: thodoxy, ${ }^{2}$ that is still so in the life of the contemporary church.

Granted, there is the tendency in contemporary Christianity to regard divine zevelation as a matter of God's initiative by which

lFor a recent and relevant discussion of this issue, see Johann-Baptist Metz and Edward Schillebeeckx, eds.. Orthodoxy and heterodoxy, Concilitm 192 (Edinburgh: T. \& T. Clark, 1987).

2 There has been a growing consensus among Christians that what men and women need most in the 1980's is not so much a knowledge of a consistently formulated doctrinal system as the interior peace that results from a personal relationship with God. Hence it is often emphasized that the purpose of the Christians' witness and their task in the world is primarily to bring man back to God as a Person, and, as a result, to reconcile human beings with one another. The fact is underlined that at the core of Christianity is Jesus Chilst himself rather than a system of doctrinal statements, a specific world-view, or a fundamental proposition. This emphasis Einds ics roots in those theologians of the nineteencin and twentieth centuries who turned to the inner religious experience of the believer as "the point of insertion of God's revelatory activity" generally denying the existence of such things as revealed doctrines (see Avery Dulles, Models of Revelation [Garden City, New York: Image Books, 1985!, p. 69). So Schleiermacher thought that whatever value is to be found in dcctrine arises from the fact that religious emotions spontaneously break forth into speech, which symbolically communicates the inner affections if the speaker (Friederich Schleiermacher, The Christian Faith (New York: Harper Torchbooks, 1963], 1:77). Auguste Sabatier, for his part, held that faith cannot without deformation of its biblical sense become "an intellectual adherence to an historical testimony or to a doctrinal formula" (Outlines of a Philosophy of Religion Based on Psychology and History, trans. T. A. Seed [London: Hodder and Stoughton, 1902]. p. 46). 
He reveals himself rather than communicates propositional doctrines. Still, even the champion of non-propositional revelation, Emil Brunner, recognized that "faith cannot exist apart from sound doctrine." I Similarly, from a modern Roman Catholic perspective, Avery Dulles observes that in Roman Catholicism the church is seen as ministering in the name of Christ to the human hunger for truth in such a way that Christian doctrine must be regarded as "a constitutive feature of the Church as it carries out its mission." 2

Hence, while many Christians acknowledge that an exaggerated emphasis on doctrine and orthodcxy may have been responsible for much of the spiritual poverty and some of the persecutions which have characterlzed certain perlods of church history, they also recognize that sound teaching is indispensable to core to an appropriate comprehension of God's character, actions, and plans. Such a knowledge is Important because it allows those who worship God to relate to Him in a more meaningful manner.

\section{The Meaning of "Orthodoxy"}

The term orthodoxy has long been ambiguous. From its initial meaning of "right belief" or "right doctrine," 3 it has

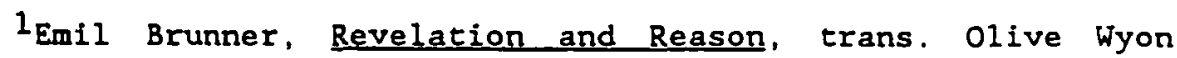
(Philadelphia: Westminster Press, 1946), p. 420.

2Dulles, Models of Revelation, p. 226. Dulles points out that due to the necessity to explain and set proper limits to the kinds of significance of Christian symbols, doctrine is indispensable. Thus, notes he, "without doctrines we could hardly find in the Cross of Christ the manifestation of divine grace and redemption" (ibid., p. 143).

${ }^{3}$ Rudolf Bultmann, Theology of the New Testament, 2 vols., trans. Kendrick Grobel (New York: Charles Scribner's Sons, 1955), 
evolved to be uncerstood in more recent centuries as "that form of Christianity which won the support of the overwhelming majority of Christians," 1 i.e., the form of Christianicy which had developed by the end of the fourth century A.D. and which Robert A. Kraft calls "classical Christian orthodoxy." 2

The evolution of the concept of orthodoxy, from its simple meaning of truth to its equation with the adjectives "approved" and "official," corresponds to a certain extent with the historical development of the Christian church and its theology. Still, this evolution has not prevented the word orthodoxy to carry in our time a twofold connotation expressing the two mentioned meanings. The term conveys primarily the meaning of "truth" for the Christian community when the latter is actively engaged in the process of defining correct doctrine. When a particular position has been reached, however, the accorded view acquires with the passing of time a certain historical fixity which is characteristic of the status of orthodoxy. Understood in this sense, orthodoxy means "the approved tesching of the church."

Looking at the issue from another perspactive, it might be observed that for those who stand on the side of orthodoxy, the term

2:135-137. Hereafter referred to as Bultmann, Theology.

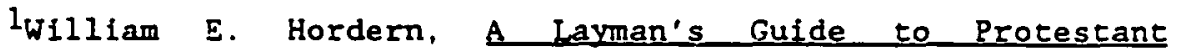
Theology, rev. ed. (New York: Macmillan Publishing Co., 1968), p. 1.

${ }^{2}$ Robert A. Kraft, "The Development of the Concept of 'Orthodoxy' in Early Christianity," in Gerald F. Hawthorne, ed., current Issues in Biblical and Patristic Interpretation. Studies in Honor of Merril $C$. Tenney Presented by His Former students (Grand Rapids, Michigan: William B. Eerdmans Publishing Company, 1975), p. 47. Hereafter referred to as Kraft, "The Development." 
is identified with "the truth," while dissenters tend to identify it with "the establishment," thus almost becoming a pejorative epithet. 1

This dichotomy points to the historical and theological aspects of orthodoxy. Historically, it may be described as "the opinion of the winners" and may be identified with "classical orthodoxy"2 or with whatever theological view has gained the official approval of a particular denomination. Theologically, the concern for being orthodox has to do with the preoccupation for continuous growth while seeking to persevere in the Christian truth, ${ }^{3}$ which may lead one to dissent from a particular historical position regarded as orthodox. One of the major tasks of theology,

${ }^{1}$ Cf. Robert Morris Johnston, "Ortheduxy and $H e=:=; ;$ in the Btblical Period: Some Reflections on an Elısive Category," a paper presented at the San Francisco Meeting of the Andrews Society for Religlous Research, December 1981, p. 3. This manuscript can be found in the arc!ilves of the Seventh-day Adventist Heritage Center, James White Library at Andrews University, Berrien Springs, Michigan.

2Orthodoxy understood in this sen:ie is what Robert A. Kraft calls "classical Christian orthodoxy," 1.2. , the type of Christianity which became mainstream by the year 400 A.D., after having gained the support of the Roman empire (Kraft, "Development," $p$. 47).

${ }^{3}$ Hans Küng himself has dealt vith this ambiguity of the orthodoxy-heresy antithesis. He is addressing the historical dimension of the problem when he acknowledges that "everything that was written cuncerning the history of the first heresies was written from the point of view of the winners, therefore, thinicing in their own justification" (Küng, Menschwerdung Gotres Eine Einfurung in Herels theologisches Denken als Prolezomena zu einer kunftigen Christologie [Fribourg: Herder, 1970], P. 612; hereafter referred to as Küng, Menschwerdung). On the othe: hand, he addresses the rheological aspect involved in the issue when he expresses his belief that it was important for the final result of the discussion to discern who represented the o:iginal Christian dostrine (ibid.). 
therefore, consists in ascertaining the extent to which the historical development of Christian theology is sound when compared with a given norm of truth. The determination of such a norm--even the discussion whether an objective norm exists at all-.is another theological issue related to the orthodoxy-heresy antithesis, perhaps the most cardinal of all.

Other nuances must be mentionad here which further complicate the issue of orthodoxy-heresy. Orthodoxy has also come to be understood in a general sense as "conformity with the prevailing doctrines of the Church," thus implying that a particular belief "may be orthodox at one time and heterodox at another."1 Furthermore, since tiue divisions of the church have given rise to as many orthodoxies as there are Christian denominaticns, the ambigulty of the term can be easily perceived.

\section{The Case of Hans Küng}

The case of Professor Hans Küng--undoubtedly one of the most prominent contemporary theologlans ${ }^{2}$-seems most relevant for the purpose of studying the problem of theological dissent from a contemporary perspective. ${ }^{3}$ One of the most controversial figures of $8: 277$.

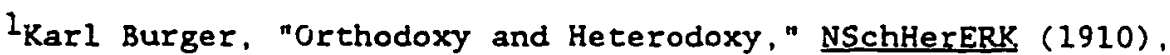

${ }^{2}$ For biographical daza on küng, and a descripticn of the main traits of his theology, see below, chapter 2.

"In the "Editorial" of Concilium 158, Hans Küng and Jürgen Moltmann declare: "Concillum is not in love with dissent and does not seek to propagate it for its own sake. But this journal does seek to ensure that in the Church today divergent voices and movements find a hearing" (see Hans Küng and Jürgen Moltmann, eds., The Right to Dissent, Conclilum 158 [Edinburgh: T. \& $T$. Clark, 
post-Vatican II Roman Catholicism, 1 the Swiss theologian had been regarded by many within his church as somehow on the fringes of orthodoxy if not actually already heretical ${ }^{2}$ some time before the Vatican deprived him of his canonical mission ${ }^{3}$ in mid-December 1979,4 though he regarded himself as an authentic son of the Roman Catholic Church. 5 Even though his ecumenical spirtt has continued

1982]. p. vil; emphasis in the originaij.

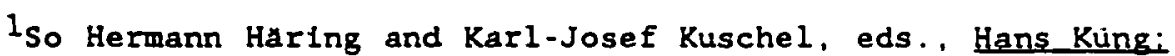
His Work and His Way, trans. Robert Nowell (Garden City, New York: Image Books, 1980), P. 7. Quoted herceforward as WEW.

${ }^{2}$ Cf. Robert Nowell, A Passton for Truth: Hans Küng and His Theology (New York: Crossroad, 1981), p.11.

${ }^{3}$ Canonical mission means "either the conferring of an ecclestastical office by a competent ecclesiastical superior accerding to law (c. 147), or the grant of jurisdiction in some other way" (CCL 1963, c. 109). For a definition of "canonical mission to preach," see CCL 1963, c. 1337-1341. The canonical mission of a theologian grants to him the faculty to teach in Roman Catholic seminaries.

${ }^{4}$ Carefully avolding the label of "heretic," the Vatican issued a Declaration which considered küng unorthodox: "Professor Hans kung, in his writings, has departed from the integral truth of Catholic faith, and therefore he can no longer be considered a Catholfc theologian or function as such in a teaching role." See "Declaration of the Sacred Congregation for the Doctrine of the Falth on Some Major Points in the Theological Doctrine of Professor Hans Küng, December 15, 1979" [hereafter referred to as CnE, "Declaration"], in Leonard Swidler, ed., küng in Conflict (Garden City, New York: Image Books, 1981), pp. 387-88.

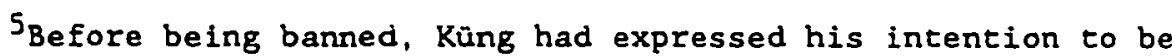
loyal to his Church and to remain a Ruman Catholic professor. He stated: "I have never made a secret of the fact that, in spice of all the difficulties which have been created for me in this my Church, almost since I received my doctorate in Theology, I remain loyal to this my Church and I stand passionately on her behalf" (Hans Küng, "Letter to Cardinal Höffner, Feb. 21, 1977, " in United States Catholic Conference, The Künz Dialogue: A Documentation on the Efforts of the Congregation for the Doctrine of the Faith and of the Conference of German Bishops to Achieve an Appropriate Clarification of the Controversial Views of Dr Hans Küng [Tübingen] 
to grow deeper, he has remained till today within the communion of that church. I

In his answer to the Congregation for the Doctrine of the Faith's statement that he had departed "Erom the integrai truth of the Catholic faith." Küng affirmed that he was still a Cacholic and that he wanted, all to the contrary, "to defend the truth of the Catholic faith."2 Thus, in Küng's confrontation with the Vatican, the dispute regarding one's understanding of the nature of truth appears as of particular significance. Having to do ultimately with the distinction between truth and erros in Christian doctrine, the orthodoxy-heresy antithesis may be regarded in this sense as being at the core of "the küng case."

(Washington, D.C.: Publications office of the I. S. Catholic Confarence, lisuj, FF. iij-116. Hereafter quoted as küng Dialogue).

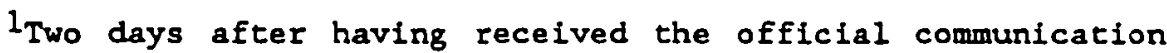
of the withdrawal of his missto canonica, Kung declared: "I have always considered myself a Catholic theologian and will continue to do so. Now as before, I regard myself as a priest of the Ecclesia Catholica. As a Catholic theologian, what was and is particularly important to me is the 'Catholic' Churcir; that is, the entire, universal, all-encompassing and whole Church. . . . It is in this spirft that I would like to continue to advocate Catholic doctrine as a Catholic theologian" ("Statement of Professor Küng, Dec. 20, 1979," In kung Dialoque, p. 169; cf. Peter Hebblethwaite, The New Inquisition?: The Case of Edward Schillebeeckx and Hans Küng [San Francisco: Harper \& Row, 1980], "Appendix 4: Hans Kung's 'Appeal' Statement," p. 163). Küng's ecumenical understandir.g of Catholicisa and his fidelity to the church have been confirmed in one of his more recent books: Why I Am Still a Christian, trans. David Smith et al., ed. E. C. Hughes (Nashville: Abingdon Press, 1987). The original German version, Woran man sict, halten kann, was published by Benziger Verlag of Zurich, in 1985.

2küng, "Postcript to the English Edition: Why I Remain a Catholic," in Idem., The Church-Maistained in Truth: A Theologicai Meditation, trans Edward Quinn (New York: Vintage Books, 1982), p. 82; emphasis added. Henceforward quoted as Küng, Maintained. 
The fact that Kung's views were defined as unorthodox by the Magisterium, added to his own treatment of the problem of heresy and related issues, makes of Küng's particular case an interesting opportunity to reflect on the general question of the orthodoxyheresy antithesis. For one thing, the confrontation between kung and Roman Catholic episcopal authorities brings into the foreground not merely the issue of religious authority but also the fundamental question as to one's criteria and norms of Christian truth. For another, the case of küng may suggest specific conclusions as to the issue of interpreting the Christian message for today and on the current relevance, especially in the context of ecumenism, of the categories of orthodoxy and heresy.

\section{Purpese of the Study}

The purpose of this dissertation is to examine critically Hans Küng's concept of heresy. This enterprise compels me to analyze also his concept of orthodoxy. "the genuine Christian message." In this way, my analysis and critique are focused on Küng's model of orthodoxy-heresy which implies an examination of his position regarding the way in which doctrinal truth and error are interrelated.

Any claim that a particular statement, view, or position is true requires justification. The proponent of such a view should provide what may be regarded as his or her "criterion"l of truth. Thus, it is not only pertinent but basic to our inquiry that we ask

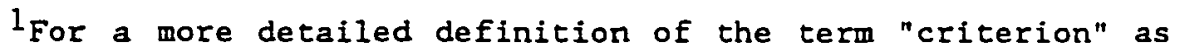
used in this dissertation, see below, pp. 18-21. 
for Küng's criterion (or criteria) of Christian truth. Why does he consider his position to be correct? In addition, what is the "norm"l which leads him to discern errors within the Roman Catholic corpus of teachings? The purpose of this dissertation is thus to study Küng's position regarding the categories of orthodoxy and heresy as such in a comprehensive and systematic way. More specifically, it attempts to identify, describe, analyze, and crificize the criteria and norms by which he judges Christian doctrines to be sound or erroneous, orthodox or heretical. ${ }^{2}$

\section{Methodology}

The methodology to be followed aims, first, at a systematic comprehension of the subject matter of the orthodoxy-heresy antithesis as it developed throughout the history of the Christian church. The nature of this task is integrative and inclusive of

${ }^{1}$ For an explanation of my use of the term "norm" as different from "criterion," see below, pp. 20-21.

${ }^{2}$ Due to the fact that kung holds that heresy ought to be measured against norms other than "orthodoxy" understood as the accepted system of doctrines (see Küng. The Church [Garden Ciby, New York: Image Books, 1976], p. 315), the use of that word in this analysis of Küng's views might be questioned on the basis that one would be imposing on this author an idea strange to him. It might have been more accurate, therefore, to choose for this investigation a title like "The Concept of Truth and Error in Hans Küng." That wording, however, has more philosophical overtones than I want to suggest. Though it is obvious that this dissertation has to pay some attention to the matter of truth and error from a philosophical perspective, its concern falls mainly into the realm of historical and systematic theology. Furthermore, the use of the rerm "orthodoxy" in connection with Küng's theology may be defended on the basis that this theologian has qualified his own work--for instance, his volume The Church--as "entirely orthodox" (see the "Letter of Hans Küng to Franjo Cardinal Seper, June 1, 1970," in Swidler, Küng in Conflict, p. 23). 
several interrelated elements. Its purpose is to discern the connections existing among the various constitutive elements of the orthodoxy-heresy antithesis so as to understand both the rationale and the implications of Küng's theological proceedings in what touches upon this matter. I deem it necessary, indeed, to come to a comprehensive and structural apprehension of the complex issue of orthodoxy-heresy as such in order to discuss the issue at stake in a fruitful way, and to perform a hopefully well-founded critique of Küng's views. My analysis of the composition of the orthodoxyheresy structure, therefore, precedes the study of K'ing's thought on this matter.

The sequence of my description and analysis of Küng's views on the orthodoxy-heresy antithesis is not only suggested by the historical-theological survey of the first chapter, but by küng's own treatment of the issues throughout his literary production as well. As a matter of fact, his first volumes dealt mostly with intra-church questions, related to the criteria and norms of classical orthodoxy, 1 whereas his writings of the last decade or so show a concentration on a widex spectrum of problems, those which are the concern of modern man as such. They are obviously related to what I call the modern ${ }^{2}$ criteria, norms, and theological issues bearing upon the definition of Christian truth.

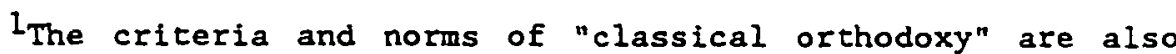
referred to in this dissertation as the "traditional" criteria arid norms of orthodoxy.

2Tne label "modern" designates the criteria, norms, and issues which came to the forefront after the Protestant Reformation.
} 
14

For the purpose of this dissertation, it is sufficient in most cases to limit my description and analysis of Küng's views to those places in his writings where his principal theses are expressed in a clear and explicit way. I am primarily interested, therefore, in those articles, essays, sections of bocks, and key statements of Küng's writings which present his views in a direct, vivid, and emphatic manner.

My critical evaluation of Küng's model of orthodoxy-heresy is focused on his own theological work. I intend to explore the consistency of the diverse aspects of his thought which bear upon the issue of defining doctrinal truth and error.

\section{Limitations}

It is not my purpose here to demonstrate whether Hans küng's views are orthodox or heretical. No judgment of value is made regarding the orthodoxy of his theological views. Nor am I perticularly interested in discussing whether Küng's dissent is justified, or whether theological dissent in general is legitimate at all.

Neither is the purpose of this research to evaluate critically Küng's positions by comparing them with Roman Catholic teachings, with the views of other theologians, or whatever other norm. Whenever such comparisons occur, they are made for the mere purpose of highlighting the main features of Küng's own position. His own views remain the focus of my research and cincern.

There are other limitations, too, especially regarding primary sources. One should not expect an exhaustive analysis of Küng's references to the various aspects of the orthodoxy-heresy 
issue. A pertinent and careful analysis of representative statements--and they are numerous enough--should suffice to describe Küng's concerns and views on each theological issue, principle, criterion, and norm of orthodoxy involved.

A further limitation should be obvious. Since Hans Kung is still contributing to the theological debate through his literary works, 1 I can deal only with his views as published thus far. In view of his unfinished theological production, and due to the fact that an evolution--which at times takes the shape of a rather radical shift-has occurred in küng's views, further developments in his theology remain a definite posstbility. Brought together, these facts underline the restricted nature of my analysis and critique.

\section{Qutline of the Study}

As mentioned earlier, in order to analyze and criticize kung's views on the orthodoxy-heresy issue in a productive way, a comprehensive view of the main constitutive elements composing the orthodoxy-heresy antithesis seems most necessary. The criteria and norms of orthodoxy, together with the most relevant principles and theological issues related with the church's definition of doctrinal truth and error, are among the constitutive elements involved in the complex structure of the orthodoxy-heresy antithesis. A consideration of Küng's attitude toward each one of these elements is indispensable if we are to reach as clear an understanding as

InI aim eventually at writing a systematic theology in the context of the world religions, a goal I may still be able to reach," revealed küng in a recent interview (see Küng, "On Being a Christian Theologian," The Critic 41 [Summer 1987]:15). 
possible of what is involved in his position concerning the orthodoxy-heresy antithesis. In addition to identifying and describing the main principles, criteria, norms, and theological issues, an understanding of the way in which they interact is of necessity. Thus, the first chapter outlines from a historicaltheological perspective the main components of the orthodoxy-ieresy issue, as they appeared throlghout the history of Christian theology. This survey not only provides us with the loci we need for an appropriate study of Küng's views on orthodoxy-heresy. It also suggests a logical sequence for the examination of these ioci and the organic interconnection that exists among them.

In chapter 2 I attempt to determine the leading concerns which constitute the starting point of Küng's theology. This shoild prove useful for one's understanding of the general trends of his theological thought and, partfcularly, of his views on orthodoxy and heresy. In my opinion, an analysis, however brief, of his formative years as a priest does indeed bring to light the genesis of these concerns and trends.

Chapter 3 covers my examination of Küng's attitude toward the "traditional" criteria, norms, and issues of orthodoxy-heresy, namely, thuse found throughout the history of the church and theology up to the time of the Protestant Reformation. At the end of this chapter, Küng's position regarding these traditional criteria and norms, along with his concept of heresy, should be clear. 
Chapter 4 focuses on Küng's reaction to the main theological issues related to the orthodoxy-heresy antithesis which came to the forefront from the time of the Reformation onward. This gives me an opportunity to address what might be regarded as the modern criteria and norms of truth

The Conclusion summarizes the main findings of the research, notes some strengths and shortcomings of Küng's views, and addresses some more general questions relatzd to the orthodoxy-heresy antithesis, especially those regarding one's criteria and norms of Christian truth. 
CHAPTER I

BACKGROUND TO THE QUERY

\section{Introdvetor: Considerations}

Although this dissertation confines itself to the problem of Hans Küng's concept of heresy, it seems pertinent, to begin with, to situate the issue within the broader horizon of the question of the antithesis of orthodoxy and heresyl considered from a historicaltheological perspective.

In sketching the broad outlines of the development of Christian orthodoxy (and, by implication, of the heresy which opposed it) and starting with NT times, my purpose is to bring into focus the main principles, criteria, ${ }^{2}$ norms, ${ }^{3}$ and theological issues ${ }^{4}$ which

1That the antithesis of orthodoxy and heresy is a distinct theological issue--and an important one, both in the history of Christianity and in the $1980^{\prime} \mathrm{s}-\mathrm{-is}$ evidenced by the literature, quoted throughout the dissertation, which addresses the issue directly. Since this antithesis is the major theological issue of this dissertation and is a complex structure in itself (see below, Pp. 27ff.), I refer to it hereafter in a technical way either as "orthodoxy-heresy" or "orthodoxy-and-heresy."

"In the vernacular sense "criterion" (Greek krinein- to separate, decide, judge; kritéfton- a means of judging, test. standard) means the principle by which a correct judgment may be formed, or the established rule or law for testing anything (see, for instance. The Random House Dictionary of the English Language, 1966 ed; and Webster's New Twentieth-Century Dictionary of the English Language, Unabridged, 2d ed., 1976). For a definition of the sense in which the expression "criteria of orthodoxy" is used in this dissertation, especially in contradistinction from "norms of orthodoxy," see the discussion below. 
have interplayed in the church's efforts to define what the correct understanding of Christian truth is and what constitutes deviation from the norm.

The Components of the Orthodoxy-Heresy Antithesis:

Principles, Criteria, Norms, and Issues

I must state at the outset that I consider that the whole theological phenomenon of orthodoxy-and-heresy, i.e., the historical confrontation between conflicting views of Christian doctrine, constitutes what could be regarded as a complex structure made up of a numiver of interrelated subsidiary elements. In studying the composition of this structure, our attention is focused on the main criteria and norms of orthodoxy which appear throughout the history of Christian theology, as well as on the most relevant principles and issues involved.

A definition of the manner in which the terms "principle," "criterion," and "norm" in this dissertation are used is necessary at this point.

By "principle" I refer to the fundamental, primary, and general notion underglrding the eriteria and norms of orthodoxy. In other words, principles are those essential concepts which may be regarded as the general frame or context necessary to understand the

3In common language a "norm" (Latin norma- rule or square of carpenter) is a standard, model, or pattern for comparing anything (ibid). See below for an explanation of the way in which I differentiate between criterion and norm of orthodoxy in this investigation.

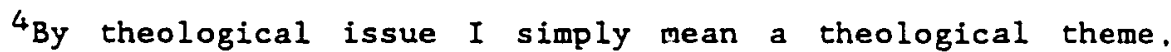
motif, or problem. The issues implied here are indeed subsidiary to the major issue of orthodoxy-and-heresy. 
criteria and norms of Christian truth. To some extent, it might be held that the criteria and norms of ortinodoxy are derived from those principles.

When I speak of criteria of orthodoxy, I have no specific technical philosophical usage in mind. I By "criterion" I merely intend to designate that which enables one to decide whether a doctrinal proposition is true or alse. In this way, the criteria of orthodoxy are related to the question as to the basis on which a particular doctrine is affirmed to be true or false (orthodox or heretical). I use the term in the broad sense of the ground, basis, or means of judging Christian doctrines as to their legitimacy. In brief. "criteria" are here understood as those general and abstract areas of reality where the elements which guide the believers in their testing of Christian truth are grounded.

Though in vernacular discourse "criteria" and "norms" aze synonyms, 2 in this dissertation I distinguish between them when referred to orthodoxy-heresy. I use the term "norm" to designate specific and concrete standards over against the more general and abstract nature of a criterion. In this usage, norms are regarded as concrete expressions of a given criterton. Norms are tangible, explicit models or patterns against which a particular doctrine can

IFor a description of some of the different ways in which the word criterion and its equivalents have been employed by many philosophers, including Giambattista Vico, Emmanuel Kant, Ludwig Wittgenstein, and the Louvain scholastics of the beginning of this century, see Anthony Kenny, "Criterion," The Encyclopedia of Philosophy (1967), 2:258-61.

${ }^{2}$ English dictionaries define both of them as "standards." 
be measured in order to verify its orthodoxy. Thus as a particular example of this differentiation, I regard authority as the general principle undergirding both the revelational and the ecclesiastical criteria of orthodoxy. As far as the revelational criterion is concerned, it points to the fact that the first Christians viewed the revealed nature of a doctrine as the criterion ${ }^{1}$ for accepting it as stating Christian truth. The teaching of the apostles and the New Testament Canon ${ }^{2}$ are the concrete expressions of the revelational criterion--to the extent that thay are beifieved to have been delivered by divine revelation-inspiration. For that reason they are regarded as specific norms which would make it possible to decide the authenticity of any alleged Christian belief.

Additional elaboration on this matter leads one to note that, from a historical perspective, some of the criteria and norms for discriminating between true and false doctrine became evident in a specific moment of the history of Christian theology, while others were obvious from the very beginning of Christianity.

In addition to the principles, criteria, and norms, the question of orthodoxy and heresy entails several specific theological issues which, from our contemporary point of view, strike one as particularly relevant. As an example of these issues and of special importance in this research is the relatively recent awareness of the existence of some subjacent and, at times,

\footnotetext{
$1_{\text {Which I call "revelational criterion." }}$

2Even though the term canon means basically "pattern," and as such it applies to the "list" of recognized apostolic documents, I use "Canon" as a synonym of "Holy Scriptures."
} 
unconsclous presupposttions or basic assimptions which ir. each historical epoch contribute to the formation of a particular worldview in which specific criteria and norms of orthodoxy fit naturally.

The identification and description of the main principles, criteria. norms, and theological issues of which the orthodoxyheresy antithesis is made up as well as the elucidatior. of the vays in which they interact is the specific purpose of this chapter. This should prepare the ground for a hopefully more comprehensive and pertinent way of analyzing and criticizing Hans Küng's proceedings in his search for Christian truth. Once identified and described, these components of the orthodoxy-heresy structure are carefully researched in Kün's writings. This methodological approach is indispensable since the orthodoxy-heresy antithesis and its constituent elements are not systematized into a single treatise in Küng's prolific Iiterary productions but rather are scattered throughout his writings.

Basic Constants in the Orthodoxy-Heresy Antithesis

Apart from the principles, criteria, norms, and subsidiary issues of orthodoxy-heresy just described, some observations dealing with certain basic features of the antithesis itself deserve to be underlined also at the beginning of this discussion.

In the first place, it should be noticed that from New Testament times there has been a constant struggle between those who regarded themselves as being right and those whom they cunsidered tu 
be wrong in regard to what Christians should believe. The history of Christian theology may be considered, therefore, as a history of the conflicts between positions which eventually came to be designated as orthodox and heretical. In other words, the distinction of the categories of orthodoxy and heresy as such (i.e.. the attitude "we are right, you are wrong") is, historically speaking, part of the very structure of the Christian theological enterprise as a whole.

Second, one must observe that even though there was room for doctrinal diversity among Christians from the beginning. I they did not hesitate to explicitly distinguish between legitimate and illegitimate teaching. ${ }^{2}$ In effect, their doctrinal tolerance proved

$I_{A}$ descriptive study of the NT reveals that this diversity exists among the neotestamentarian documents, and that a diversity wider than the $N I$ Canun is spoken about there in terms of false teaching. The diversity found in the NT has been underlined, among others, by F. F. Bruce's Peter. Stephen. James, and John: Studies in Early Non-Pauline Christianity (Grand Rapids, Michigan: Wm. B. Eerdmans Publishing Co., 1980); James D. G. Dunn, Unity and Diversity in the New Testament: An Inquiry into the Character of Earliest Christianify (Finiladelphia: The Westminster Press, 1977); Bultmann, Theology, 2 vols.; Bauer, Orthodoxy and Heresy; James M. Robinson and Helmut Koester. Trejectories Through Early Christianity (Philadelphia: Fortress Press, 1971); Ernst Kasemann, The Testament of Jesus: A Study of the Gospel of John in the Light of Chapter 17 . trans. Gerhard Krodel (Philadelphfa: Fortress Press, 1968); and Hans Dieter Betz, "Orthodoxy and Heresy in Primitive Christianity," Interp, 19 (1965):299-311.

2Would it not have been anachronistic for early Christians to think of "orthodoxy" as that form of Christianity which had the support of the majority and which "is expressed by most of the official proclamations or creeds of Christian groups"? (cf. Hordern, A Layman's Guide, p. 1). Furthermore, it must be recognized that the term orthodoxy itself was not frequent in Christian 1iterature until the fourth century (see Kraft, "The Development," p. 48; also entries in G. W. H. Lampe, Aatristic Greek Lexicon [Oxford: At The Clarendon Press, 1961-68]). Still, it seems correct to maintain with Kraft that "from as far back as we are able to go in Christian 
to have its limtes, 1 especially when the mentioned diversity involved teachings of central importance for the integrity of the Christian message such as Christology ${ }^{2}$ and soteriology. 3 One also must be aware of the fact that all Christian writers regarded themselves as the defenders of the Christian truth. 4 It was precisely their concern for the divinely revealed truth and their zeal for the preservation of what they considered to be the true original Chisistian message ${ }^{5}$ that caused the categories

history, the claim 'I am right,'" standing over against some alternative claim, "was made by various people in various connectlons" (Kraft, "The Development," p. SO).

In the church of the first century "there was a degree of variation permitted and represented in our New Testament canon," notes Johnston, "then there was a wider variety which lay outside the fence of our canon, but whose representatives doubtless considered themselves the true followers of Christ" (R. M. Johnston, "ürtiodoxy and Heresy in the Biblical Perlod," p. 16).

2 The allowable diversity extant among first-century Christians was more restricted when they dealt with the person of Christ. This can be inferred from the NT documents, whose condemnation of Christological heresies is frequent. See, for instance, 2 Pet 2:1-2; 1 John 4:1-3;2 John 7; and Jude 4 .

${ }^{3}$ Paul, in particular, strongly rejects both the legalism of some conservative Jewish Christians (in Galatians) and the antinomianism of those who, at the other extreme, had Gnostic cendencies (in 1 Corinthians).

${ }^{4} \mathrm{Cf}$ Marshall, "Orthodoxy and Heresy," pp. 7-8; see also Jaroslav Pelikan. The Emergence of the Catholic Tradition (100-600). The Christian Tradition: A History of the Development of Doctrine, vol. 1 (Chicago and London: The University of Chicago Press. 1971). p. 69; hereafter referred to as Pelikan, Catholic Iradition. This is already so among the writers of the NT (e.g., Gal 1:6-9; Jude 14) as well as among non-canonical orthodox authors (e.g., Pol. Phil 6:3-7:1; Ign. Eph $9: 1$ ) and heretics (see, for instance, reference to Valentinus, Marcion, Cerinthus, and Basilides in Irenaeus Adrersus haereses 3.2 .1 (ANF, 1:415]).

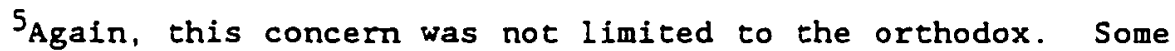
Gnostics of the second and third centuries A.D., for instance, 
of orthodoxy and heresy (1.e., true and false teaching) to come into focus early in the history of the shurch. Christian wricers did not see themselves contending merely for their own opinions but for the truth that "was once for all entrusted to the saints" (Jude 3 ). 1

A careful consideration of both the documents of the NI and the history of Christian thought permits one to regard the facts expressed in these three observations as constanis which have been present at least until the last century. 2

At this functure, a word must be said regarding the presuppositions which undergirded the early Christians' theological reasoning, Especially from the second century onward, ${ }^{3}$ and which contributed to shape their concept of Christian truth. In their encounter with the Hellenistic culture of their time, they found a pattern of thought which in their view appropriately helped them to equate the truth of revelation with a transcendent reality that was ultimate, absolute, and eternal. Accustomed to Hellenistic philosophical categorles, the church fathers could only think of

claimed to preserve the true teaching of Jesus Christ by means of a secret tradition which they allegedly had recefver :- rough apostolic succession (see, for instance, Ptolemaeus Ad Floram epistola [PG, $7: 1289,1291]$ ).

${ }^{1}$ Unless otherwise indicated, Bible quotations are from the New International Version (NIV), (The Holy Bible: New International Version [Grand Rapids, Michigan: Zondervan Bible Publishers, 1978]).

${ }^{2}$ As pointed out in some detail below, the relativistic trends of the last two centuries tend to discourage the use of the categories "orthodoxy" and "heresy" in contemporary theology.

${ }^{3} \mathrm{It}$ is almost unanimously accepted today that Christian theology is always influenced by the conceptual framework and by the specific world-view of the time. The fourth chapter in this study shows that this issue is of central importance for orr dissertation. 
truth, as such, to be absolute. 1 Therefore, they expressed the truths of Christian revelation in the framework of the philosophical system available to them. 2 This was not merely the resuit of an unconscious reflection in accordance with the dominant pattern of thought accessible to them but also of their striving for communicating the Christian message in a language relevant for the minds of their time.

Their insight concerning the nature of transcendent reality would lead all parties to agree, throughout the controversies from A.D. 100 to 600 , that there is "only one true doctrine," which each of them, however, claimed to possess. ${ }^{3}$ Additionally, to their understanding of the absoluteness of truth, the early fathers joined their epistemological presupposition which regarded truth as the correspondence between the content of the mind and reality. ${ }^{4}$ Not only was truth regarded as one, monolithic, and absolute, but in their view it could be grasped by the mind in the same way as, say,

In correlation with this, the Pateristic concept of God, following the petterns of Platonic and Arfstotelian philosophy, conceived the supreme Being as essentially transcendent, unchangeable, unmovable, infinite, eternal (not in the sense of "everlasting" but in that of being "out of the dimension of (tme"), and absolute. This Being was the ground of all truth which in consequence was also absolute, unchangeable, and timeless (For a more detailed discussion of this issue, see below, pp. 323-35).

${ }^{2}$ Divine revelation (the origin of theological knowledge) and philosophy (human reflection, thinking, reasoning, or intellectua. activity) are the two indispensable dimensions in every structure of meaning given in the God-man encounter.

${ }^{3}$ See Pelikan, Cacholic Tradition, p. 69.

"For a more detailed discussion of the "correspondence" theory of truth, see below, PP. 262-65. 
a camera records a scene on a film. Of course, everyone believed to be taking good pictures.

This observation presents an issue of importance for the present dissertation, namely, the influence of philosophical presuppositions upon theological reasoning. The relationship between philosophy and theology may be considered as a fourth constant which has modified the antithesis of orthodoxy-heresy throughout tistory. 1

Having made these necessary observations, we may now enter into the analysis of the orthodoxy-heresy antithesis from the perspective of the historicai-theological category. The discussios that follows attempts to recapitulate in a succinct way a development that is vastly more complex than this summary would suggest. It is sufficient, however, for the purpose of this chapter to identify the main principles, criteria, norms, and theological issues relevant to the orthodoxy-heresy antithesis. The description of the development of what is here called classical orthodoxy (following Kraft) ${ }^{2}$ and of the later bifurcation of Roman Catholic and Protestant orthodoxies is in dialog with the interpretation of the facts made by ancient and modern scholars.

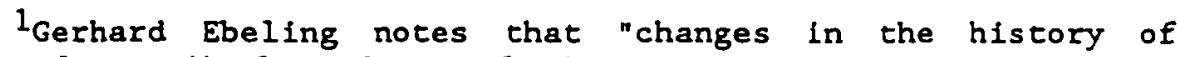
theology always display close relations to contemporary variations in the history of thought in general." This ought to be regarded as normal, holds he, since "Theology, in so far as it remains true to its task, of its very nature moves with the times, i.e., it accepts the language, thought-forms and approach of the present" (Gerhard Ebeling, Word and Faith, trans. James W. Leitch [Philadelphia: Fortress Press, 1963], P. 26).

$$
{ }^{2} \text { Kraft, "The Development," p. } 47 .
$$


Orthodoxy and Heresy in the Ante-Nicene Church

As already noted, the antithesis of orthodoxy and heresy has marked Christianf.ty throughout its whole history. Even though the word "orthodoxy" does not occur in the documents of the New Testament, ${ }^{2}$ and the related term "heresy" does not always refer

$1_{A}$ distinction must be made between the word and the concept of orthodoxy. Bultmann nctes that in the apostolic and postapostolic period, the actual words "orthodox, " "orthodoxy, " and the verb "be orthodox" do not yet occur; "they belong to philosophical usage" (Bultmann, Theology, 2:136). As to the concept of orthodoxy, Dunn holds that it only began to emerge within the Christian congregations in the struggle between different viewpoints (Dunn, Unity and Diversity, p. 3). According to Bultmann these differences took place "very early," even at the time of Paul's cursing of the Judalzers who preached a "different gospel (Gal 1:6-9)" (Buicmann, Theology, $2: 135$ ). In uther words, the concept of orthodoxy existed prine to the development of a terminology to describe it (cf. Marishall, "Orthodoxy and Heresy", p. 7: see also Kraft, "The Development," p. 48), even though in the apostolic age orthodoxy may have been "a matter rather of instinctive feeling than of fixed and definable doctrinal norms" (Henry E. W. Turner, The Pattern of Christian Truth: A Study in the Relations Between Orthodoxy and Heresy in the Early Church, Bampton Lectures 1954 [London: A. R. Mowbray \& Co., 1954], pp. 9-10).

2 The fact that the word "orthodoxy" does not occur in the NT may indicate that the Elght which its writers carried on against what they considered to be false teaching was not made from the standpoint of a fixed, elaborated system of doctrines but from the simpler perspective of the keryoma, the proclamation of the Christain communities' central confession of faith and the basic teachings related to it. In other words, it seems that the attitude of the NT authors was to identify spontaneously and intuitively what was not legitimate Christian teaching rather than to define orthodoxy in a systematically elaborated way. Henry E. W. Turner suggests that the reaction to false teaching in the neotestamentarlan church seems to have been "There is something spurious here," or "This is not the pattern of saving faith, "rather than "This is inconsistent with an achieved doctrinal standard" (Turner. The Pattern, p. 10). One is aware of the fact that some theologians, like Walter Bauer and Rudolf Bultmann, hold that in the first century "a norm or an authoritative court of appeal for doctrine is still lacking" (Bultmann, Theology, 2:135; cf. Bauer, Orthodoxy and Heresy, $p . \quad x x v$ and passim). Indeed, it is not difficult to recognize that at that time there was no standard achieved by an 
there to false teaching, 1 it is clear that already in NT times there

official conciliar consensus of any sort. On the other hand, it must be noticed that already the IV documents show that Christian writers considered Jesus Christ's life, deeds, and teaching as well as the Scriptures of the Old Testament as normative. Cf. J. N. D. Kelly, Early Christian Doctrines, rev. ed. (San Francisco: Harper \& Row, 1978), p. 31. Bultmann himself admits that from the beginning there was something which distinguished Christianity from Judaism and the heathen, in spite of the great "diversity of theological interests and ideas" existing in its ranks. This essential feature of Christianity was "the faith" which, understandably, Bultmann concedes, in the first doctrinal battles took tis the weaning of right belief or "the right kind of faith" (Bultmann, Theology, $2: 135)$.

The existence of a central confession of faith and of some basic beliefs which were common to the first Christian communities seems to be "rall established. Called "the faith," these beliefs were stressed in the church's proclamation and teaching as the church expanded and the apostles and the disciples encountered opposition on all sides. See Dewey M. Beegle, Scripture. Tradition. and Infallibility (Grand Rapids, Michigan: W. B. Eerdmans Publ. Co.. 1973), p. 40. In his book Unity and Diversity, Dunn affirms that even though in the NT "the breadth of diversity is not inconsiderable," it is possible to speak of a central confession of faith, a "unifying core for the post-Easter kerygma" (Dunn, Unity and Diversity, pp. 6-7). There are three components to this "core kerygma," observes Dunn, namely, the belief in the resurrection of Jesus and his exaltation to heaven; second, the call for falth and acceptance of the proclamation, and commitment to the proclaimed jesus; and finally, the promise held out to faith: forglveness, salvation, eternal IIfe, union with Christ (Ibid., pp. 29-32). For further discussion of the kerygma of early Christianity see, for instance, Charles H. Dodd, The Apostolic Preaching and Its Developments (New York and London: Harper \& Brothers Publishers, 1944); Karl Rahner and Heinz Schümann, "Kerygma," LTK (1961), 6:122-26; Hans-Werner Bartsch, ed., Keryoma and Myth: A Theological Debate, 2 vols. (London: S.P.C.K., 1962), particuiarly the articles by Rudolf Bultmann; see also Carl E. Braaten and Roy A. Harrisville, eds., Keryoma and History: A Symposium on the Theology of Rudolf Bultmann (New York and Nashville: Abingdon Press, 1962); Gerhard Ebeling, Theology and Proclamation: Dialogue with Bultmann, trans. John Riches (Philadelphia: Fortress Press, 1966); and Eberhard Simons, "Kerygma." SM (1969), 3:245-48.

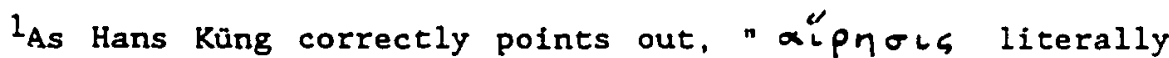
means choice, selection, a minority opinion, and was used in the Greek world to describe... a school or tendency, in Judaism to describe a religious school or party like the Pharisees, the Sadducees and the Essenes (cf. Acts $5: 17 ; 15: 5 ; 26: 5$ ) " (Küng. The Church. pp. 314-15). Therefore, Küng continues, the primitive 
was a confrontation between what was considered by each contending party to be true and false Christian teaching. 1 This can be shown in NT documents, particularly in the Pastoral epistles, in 2 Peter, 1 and 3 John. Jude, and Revelation, as well as in some assertive Pauline statements such as Gal $1: 6-9.2$ of special interest here is

Church, "small and unimportant, was regarded as a Jewish 'heresy', the 'sect of the Nazizj:is' iA:ts 2'4:5; ef. 24:14; 28:22)." Heresy has the basic sense of "faction". "party spirit", and "dissension" (Gal 5:20; 1 Cor 11:19; Titus 3:10). Besides this "neutral sense", however, heresy is also used in the NT "in a definitely negative sense. . . 'Heresy' means a fellowship which questions the whole basic faith of the ecclesia by presenting 'another gospel' (cf. Gal 1:6-9)" (ibld.). See also Bultmann, Theolory, 2:137.

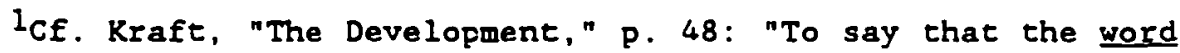
'orthodoxy'. . . does not occur in the earliest Christian writings is not to deny that some early Christians believed themselves to be 'right' while they considered others to be 'wrong'." See also Marshall, "Orthodoxy and Heresy," pp. 12, 14. In this article. Marshall examines the view which has gained a wide following since the first publication in English, in 1971, of Walter Bauer's important book Rechtrlaubigkeit und Ketzerei im altesten Christentum (Tubingen: Mohr/Siebeck, 1934). Bauer contends that the categories of "orthodoxy" and "heresy" are a later development, foreign to New Testament Christianity. His main thesis is that the Christian world of the second century, split by many different conceptions of the gospel, was first forr.ci io face the problem of orthodoxy by the ecclesio-political aspirations of the Roman church. In effect, he holds that there was no "pure" form of Christianity that existed in the beginning which can be properly called orthodoxy. His point is that the "ecclesiastical position" which asserts that orthodoxy aiways preceded heresy (i.e., the "unbelief, right belief, wrong belief" model) proves to be historlcally wrong (Bauer, Orthodoxy and Heresy, p. xxiil). In the early church there was considerable varlety of belief and no uniform concept of orthodoxy at all, he thinks, only different forms of Christianity contending for the fidelity of believers, so that what later came to be regarded as orthodox was not consclous of being such at first. Marshall, however, replies that a survey of the NT shows that the writers of the NT were conscious of the existence of opinions different from their own in the church, that they regarded them as incompatible with the gospel which they believed themselves to have inherited, and that certain groups were regarded by them as deviationist (Marshal1, "Orthodoxy and Heresy," pp. 12-13).

\footnotetext{
2This thesis not only disputes Walter Bauer's view of a lack
} 
the criteria and norms by which the early Christians defined doctrinal truth.

The Principle of Authority and the Revelational Criterion of Orthodoxy

One ought to keep in mind that in earllest Christianity, at the time when the apostles were alive and the documents of the NT were still in the process of production, the discrimination between true and false belief and teaching ${ }^{1}$ was a matter of living activity

of distinction between true and false teaching in early Christianity, it also challenges, with Bauer, the long dominant Eusebian modeI which affirms that there was a time, at the beginning, when the church was perfect and doctrine uncorrupted, and that therefore heresy represents a later perversion of an original orthodoxy. Eusebius of Caesarea quotes in his Ecclesiastical History Hegesippus' metaphor of the church as a virgin and comments on his account of the itme when he thought new (1.e., heretical) ideas were first introduced into Christianity, namely, in the early second century. Writes Eusebius: "Until then the church had remained a virgin, pure and uncorrupted. . . But when the sacred band of the apostles had in various ways reached the end of their life,. . . then godless error began to take shape through the deceit of Ealse teachers, who - . attempted to counter the preaching of the truth by knowledge falsely so called" (Eusebius Ecclesiasticae historiae 3.32.7-8. See an English translation in Eusebius, The History of the Church from Christ to Constantine, trans. and incrod. by G. A. Williamson (New York: New York University Press, 1966], p. 143). For a discussion on Hegesippus and Euseblus' view of the original unanimity of doctrine in the church and the introduction of heresy as posterior "innovation," see Robert L. Wilken, The Myth of Christian Begin: nings: History's Impact on Bellef (Garden City, New York: Doubleday \& Company, 1971), chaps. 2 and 3.

As to evidences in the NT of the fact that every party considered itself on the side of the truth, see, for instance, Rev 2:15: the church in Pergamum had among its members "those who hold to the teaching of the Nlcolaitans;" also Rev 2:20: the church in Thyatira is rebuked for tolerating Jezebel "who calls herself a prophetess;" and Rev 3:9, "Those who are of the synagogue of Satan - . claim to be Jews though they are not, but are liars."

$1_{\text {Throughout this dissertation the terms "doctrine" and }}$ "belief and teaching" are used as synonymous. As a working definition, I consider doctrines as formulations of that which the church believes and teaches. 
in the church. 1 According to the NT testimony, even though Christians regarded the writings of the OT as their authoritative Scriptures, 2 they also accepted tile tonching of the ap̃usiles as invested with the Lord's authority. ${ }^{3}$ Furthermore, they believed that the permanent activity of the Holy spirit guided the church not only in matters of daily life but also in illuminating the believers in their understanding of the true meaning of both the OT Scriptures and the prociaimed deeds and words of Christ. God's leading and ruling in matters of Christian life and doctrine was exercised through the dwelling of the Holy Spirit in the leaders of the church. 4 This may be labeled the "pneumatic-charismatic" model of authority. 5

IThis living activity of discrimination between true and false Christian doctrine, guaranteed by the charism of the Holy Spirft, is what the Roman Catholic Church claims nowadays for its episcopal Magisterium.

2It musi be observed that the Lord Jesus' use of the Scriptures of the OT reveals that he regarded them as possessing divine authority. See, for instance, the pericope of the temptation of Jesus in Matt 4:1-11 and the Lord's saying in John 5:39. That both the apostles and the first disciples also held the Scriptures in highest esteem is expressed in suich passages as 2 Pet $1: 19-21 ; 2$ Tim 3:14-17; and Acts 17:11.

${ }^{3}$ In Acts 2:42 we read of Christian converts who "devored themselves to the apostles" teaching." The church is said, in Eph $2: 20$, to be "built on the foundation of the apostles and prophets, with Christ Jesus himself as the chief cornerstone," while Peter exhorts the readers of his second letter $(3: 2)$ "to recall. . . the command given by our Lord and Saviour through your apostles." In his warning against the heretics Jude wants his readers to "remember what the apostles of our Lord Jesus Christ foretold" (Jude 17).

${ }^{4}$ This does not mean that the Holy Spirit did not also indwell each member of the Christian community.

${ }^{5}$ As an initial working definition, authority is described essentially as one's right to rule. For further explanation on the 
In early Christianity the general principle of authority found concrete expression in the "revelational criterion," which might be regarded as the first criterion of oithodoxy in the history of Christian theology. The important fact which comes to sight here is that the first Christians recognized that the legitimacy of their beliefs was based on divine authority, which, for them, meant specifically that the Christian message had been delivered by divine revelation. When asked about their reason for holding to their particular beliefs, Christians answered with a "thus said the Lord." Christian truth was defined by the authority of revelation, 1 not by the logics of reason or by empirical evidence. Later, the principle of authority would find expression in the ecclesiastical criterion of orthodoxy, which shall retain our attention subsequently in this chapter. It should be pointed out at this junction, however, that I count both the revelational and the ecclesiastical among the "traditional" criteria of Christian truth. In other words, they are the main criteria of "classical orthodoxy."

The principle of religious authority is the generai ground on which the criteria for distinguishing between correct and false belief were established. The notion of authority was present in the conscience of the apostolic church, along with its awareness of the existence of God, from its very beginning. That the orthodoxy of a doctrine is defined on the ground of divine authority means that it

meaning of authority, see the discussion below.

I On the relationship between the principle of authority and the revelational criterion of orthodoxy, see the discussion below. 
is not defined on philosophical, scientific, or any other ground. The early church's acceptance of the authoritative nature of its beliefs and teachings should not surprise us if we keep in mind that Christianity was from its inception firmly rooted on its selfunderstanding as a religion of revelation rather than a system of philosophical speculation or a scientific theory of the world.

As for the term authority Itself, while it is filled with a multitude of meanings, 1 it is used throughout this dissertation as "a zelational word which signifies the right to rule. It is expressed in claims and is acknowledged by compliance aud conform1ty." 2 In this sense, we may consider that God's right to rule in doctrinal matters (his teaching authority) was acknowledged by the first Christians who were willing to relate to Him reverently and recognized $\mathrm{Him}$ as their ultimate authority. Indeed, Christianily has traditionally claimed that all authority comes ultimately from God. ${ }^{3}$

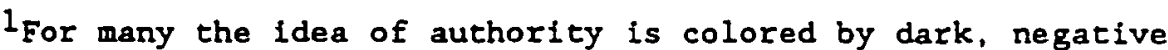
images (see Gregory G. Bolich, Authorlty and the Church [Washington, D.C.: University Press of America, 1982], F. 1), and associated with arbitrary, despotic, capricious, and absolutist rulers. It is thus identified with "authoritarianism," namely, that corrupt form of exercising command that demands submission which "cannot be justified in terms of truth or morality" (J. I. Packer, Freedom. Authorfty \& Scripture [Leicester, England: Inter-Varsity Press, 1981], p. 16). Not a few think that authority is immediately related with, and necessarily opposed to, the idea of freedom. For them, this makes of authority something despicable. On the other hand, A. E. J. Rawlinson attempts to prove that a synthesis between authority and freedom is both possible and necessary (Rawlinson, Authority and Freedum. The Bishop Paddock Lectures for 1923 (London: Longmans, Green and Co., 19331).

${ }^{2}$ packer, Freedom. Authority \& Scripture, p. 15.

${ }^{3}$ Cf. Jack Dominian, Authority (Huntington, Indiana: Our 
The early church, however, was not without doctrinal controversies. The diversity already evident in the first century A.D. 1 originated some theological differences which at times caused conflicts between the contending parties ${ }^{2}$ (see e.g., 1 John 4:2b-3; cf. 2:18-19). In view of these controversies the question necessarily arose concerning the specific authority which might determine "right" doctrine. ${ }^{3}$

The situation of a church which was organized in accordance wth its falth in the leading activity of the Lord through his Spirit during the so-believed short span of time prior to his return, could not remain unchanged when every individual Christian was claiming the guidance of the Holy spirit while holding beliefs that at times were contradictory with those of his or her fellowbellevers (see 1 John 4:1). The pneumatic-charismatic model of authority, 4 tinen, did not seem to be suitable for settling the

Sunday Visitor, 1976), p. 7 .

IThe existence of such a diversity seems to be undisputed even by evangelical NT scholars. I. Howard Marshall, for instance, asserts that the only valid point in Walter Bauer's thesis is that there was a variety of belief in the first century (Marshall, "Orthodoxy and Heresy," p. 13; cf. Daniel J. Harrington, "The Reception of Walter Bauer's Orthodoxy and Heresy in Earliest Christlanity During the Last Decade," HTR 73 (1980):292).

2 Variety of belief does not necessarily mean that conflict has to arise. Nevertheless, when such variety goes beyond mere pluralism into open contradiction, and a central teaching of the church is challenged thus threatening the spiritual stability and the very existence of the community of faith, the categories of true and false teaching become relevant.

${ }^{3}$ See Bultmann, Theology, 2:138.

${ }^{4}$ see above, p. 32 . 
controversies which sprang from such contradictions. The necessity of a concrete court of appeal or specific authority able to settle the doctrinal conflicts which at times threatened to divide the church became obvious. Some urgent questions arose: Who was to judge among differing opinions? Who was to decide the legitimacy of an alleged spirtt-led instruction? In brief, these questions express the concern as to "the norm" which was to define who was right and who was deviant. 1 The issue was not whether or not Christian beliefs were based upon divine authority. ${ }^{2}$ For the first Christians the problem of authority was confined to what in the view of some is to be called "mediate authorities," 3 which may be also

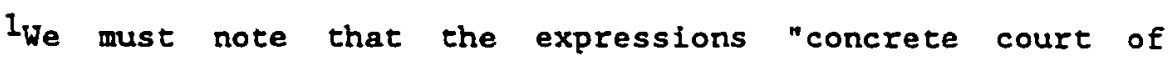
appeal," "specific authority," "mediate authority," and "norm" are in this context synonymous.

In addition, the early church recognized that God's final authority was manifested in the person of the Lord Jesus. See J. Norval Geldenhuys, Supreme Authorfey. The Authority of the Lord. His Apostles and the New Testament (Grand Rapids, Michigan: Wm. B. Eerdmans Publishing Company, 1953), p. 13.

3 Besides the authortty of God which is traditionally recognized by Christiañs as final, some authors, like Dennis Campbel1, have spokon in terms of "mediate authorities," i.e., some "critical tools"--used to judge among conflicting theological positions--such as the Bible, church tradition and teaching, the inner experience of individual believers, and philosophical reasoning (Dennls M. Campbell, Authorfty and the Renewal of American Theolory [Philadelphia: United Church Press, 1976], p. 2). Campbell correctly points out that "Christianity has never been of one mind with regard to mediate authority for theological thought and ethical prescription" (ibid., p. 3). These mediate authorities are the ones that Rupert Davies wants to replace by the concept of "witnesses" to the supreme authority of Jesus Christ. His argument is that since Christ himself is for the Christian the supreme authority, what we need are "trustworthy witnesses" rather than "unimpeachable authorities" (Rupert E. Davies, Religious Authority in an Age of Doubt [London: Epworth Press, 1968], p. 219 and passim). In brief, to put it in Auguste Sabatier's words, "the divers religious orthodoxies differ, as to the form or the seat of authority; some 
identified with what in this dissertation are labeled "norms" of orthodoxy.

Agreeing on an authoritative norm which defines true Christian doctrine and prescribes religious belief ${ }^{1}$ can be considered one of the most disturbing problems arising from the questicn of orthodoxy-heresy. It can also be regarded as the fundamental theological issue $^{2}$ concerning the structure of the orthodoxy-heresy antithesis, particularly at the inception of Christianity. Indeed the issue of religious authority--placed in center stage from the beginning of the Christian theological reflection--is, for some, at the heart of most if not all theological questions. 3

put it in the Bible, others in the Church; but they are in accord as to its nature. All of them claim that the authority which they have constituted within themselves is the expression of a divine authority" (Auguste Sabatier, Beligions of Authority and the Religion of the Solrte [New York: McClure, Phillips \& Co., 1905], p. xxvili).

l Bernard Ramm observes that the matter of authority in religion refers to a basic problem: "Is there anything in religion which demands that a man think a certaln way about religion and not another? Is there a man, a society, a principle, or a document which has the right to prescribe religious belief?" (B. Ramm, The Pattern of Authorfty [Grand Rapids, Michigan: Wm. B. Eerdmans Publishing Co., 1957], p. 16).

2 The issue of religious authority consists basically in applying the principle of authority in a concrete way.

${ }^{3}$ So Rupert E. Davies, The Problem of Auchority in the Continental Reformers (London: The Epworth Press, 1946), p. 9. Similarly, Ronald Leicester affirms that almost all theological questions are wrapped up in the question of religious authority (Leicester, "Opening Speech", in Authority and the Church: Papers and Discussions at a Conference Between Theologians of the Church of England and the German Evangelical Church, ed. R. R. Williams, Bishop if Leicester [London: S.P.C.K, 1965], p. ix). P. T. Forsyth calls the question of authority "the central question of religion." 
The teaching of the apostles as a norm of orthodoxy

At this point it may be profitable to examine the problem as to the norm which was to define correct doctrine through the testimony of the apostle Paul, who often found himself confronted by religious opponents and whose corpus of writings is sufficiently large to be used for this spectfic purpose. His case may be considered as an illustration of the dilemma of the early church regarding who was rlght and who was deviant.

In referring to the experience of Paul, I address what may have been the first movement towald the development of "classical orthodoxy," namely, the recognition of the apostles as the bearers of a reliable and authoritative tradition, 1 and hence of their teaching as the norm of Christian orthodoxy.

In the Prologue of his book he specifies that "the conviction in these pages is that the principle of authority is ultimately the whole religious question" (Forsyth. The Principle of Authority in Relation to Certainty, Sanctity and Society, 2d ed. [London: Independent Press, 1952], pp. 17, 2).

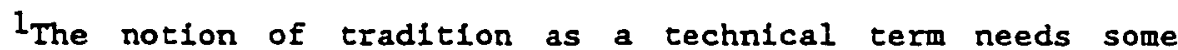
definition. In the language of the New Testament (e.g.. Luke $1: 2 ; 1$ Cor 11:2,23; 15:3; 1 Thess 2:13; Col 2:6; 2 Pet 2:21; Jude 3) as of the early fathers (e.g., Pol. Phil $7: 2 ; 1$ Clem 7:2; Did 4:13; Barn 19:11), the term conveyed the idea of "transmission" ( $\pi \alpha p$ á $\delta \circ \sigma(\zeta)$, i.e., authorftative delivery. By tradition the early fathers usually meant doctrine which the Lord committed to the church through his apostles, irrespective of whether it was handed down orally or in writing (see Kelly, Early Christian Doctrines, pp. 30 31; cf. Bultmann, Theology, 2:119-27). More recently, tradition has denoted the body of unwritten doctrine handed down in the church, in contradistinction from the Scriptures, as indicated in the Council of Trent "Decree on Apostolic Tradition and Holy Scriptures" (see Henry Denzinger. The Sources of Catholic Dogma, trans. Roy J. Deferrari from the 30th ed. of Denzinger's Enchiridion Symbolorum. rev. Karl Rahner [St. Louls, Missouri: B. Herder Book Co., 1957], no. 783. Quoted hereafter as Denz.). 
When Paul's authorlty (which was not final but mediate) was disputed in the churches of Galatia, Christian believers faced the dilema as to whom they were to listen--Paul or to his opponents. This in turn implied a more basic question: What was the criterion by which their claim of authority and correctness was to be assessedî Paul's answer involved tine revelational criterion. The rightness of his doctrine came from its origin in the Lord's revelation. I He indeed claimed divine endorsement for his teachings: "The gospel I preached is not something that man made up. I did not receive it from any man, nor was I taught it; rather, I recelved it by revelation from Jesus Christ" (Gal 1:11-12).

One may suppose, however, that the apostle's opponents, those "false brothers [who] had infiltrated our ranks" (Gal 2:4), claimed the same divine origin for their own teaching. 2 To what or to whom could paul appeal as a norm for the correctness of his teaching in this situation? Since the logical answer, i.e., "to the teaching of Jesus Christ," seemed to be the answer of his opponents, too, Faui's argument was that his preaching of the gospel had been accepted by those who were apostles before he was (Gal 2:6-10; cf.

1since Christianity came into the world as a religion of revelation, it is of its esse to claim a supernatural origin for its message. Its ultimate source lays in Jesus Christ as the cilmax of God's revelation (see Kelly, Early Chrtstian Doctrines, pp. 29 ff.).

2 Jaroslav Pelikan observes that "the heretics were no less implacable than the orthodox in claiming that only their position was the correct one" (Pelikan, Cacholfc Tradition, p. 69). This fact may explain why $R$. Bultmann holds that an appeal to a revelation directly accorded by the Lord or by the Holy Spirit "could only make the problem all the more delicate and the embarrassment all the greater" (Bultmann, Theology, 2:138). 
1:17) and who also had received their message directly from the Lord. In effect, fourteen years after his first visit to Jerusalem to see Peter and James, he had gone in response to a revelation to those "who seemed to be leaders" in Jerusalem and privately "set before them the gospe? that I preach among the Gentiles" (Gal 2:2). The apostles had recognized that Paul's teaching was in harmony with what they had recefved from the Lord, and that, therefore, it had the endorsement of God's authority (Gal 2:7-9). The matter of Paul's authority was thus settled in apostolic collegial agreement. This would mean that the revelational and an ecclesiastical criteria were working along the same lines. 1

The importance of this incident can hardly be overestimated. It should be noticed, first, that Paul did not receive his authority inrough apostolic succession, though it was recognized iy the college of the apostles. The implicit notion of an apostolic college, which included such diverse views as those of Peter, Paul, James, and John (Gal 2:9).2 discarded the individual authority of any of the apostles as the only or superior norm of Christian truth. ${ }^{3}$ In the second place, the juxtaposition of direct revela-

$1_{\text {What }}$ needs to be underlined here is that the Christian truth was not seen as entrusted to one individual alone, but to the whole ecclesia.

${ }^{2}$ On this matter, see F. F. Bruce's relevant study Peter. Stephen. James, and John: Studies in Early Non-Pauline Christianity.

${ }^{3}$ Edwin Hatch notes that the mainstream church found it necessary to lay stress on an "apostolic consensus." All parties within the church agreed as to the need of a tribunal, observes he, but the problem was that each party had its own, i.e., each mude its appeal to a different apostle. The Gnostics, for instance, built upon one apostle or another. Thus Basilides preferred to follow a 
41

tion ${ }^{1}$ and mediated tradition ${ }^{2}$ as sources of authority was unquestionably the reality in the life of the early church. In fact, Paul himself appeals to some teachings which, it seems, he did not recefve through direct revelation but through the channel of human tradition ( 1 Cor 15:3-7). This tradition had its origin, however, in God's Revelation, namely, in the Christ-event. Finally, the private nthil obstat which Paul's teaching received from "those reputed to be plllars" and, on the other hand, the objections to his preaching by those whom he regards as "false brothers"-whose position had, however, influenced Peter's conduct (Gal 2:11-16)-witness not only to the diversity that existed in the early church but also to its necessity to define the latitude of acceptable varlety of doctrine.

In Paul's case one discerns that, in consonance with and in addition to both the principle of authority and the revelational

tradition from Matthias (see Hippolytus Refutation of All Heresies 7.8.1 [ANF, 5:103]), the Naasseni traced thelr doctrine to James (Hippolytus Refutation 5.2.1 (ANF, 5:48]), and Valentinus was said to be a follower of Thelidas, who was a pupil of Paul (see Clement of Alexandria Stromata 7.17 (ANF, 2:555]). Origen explains the origin of Christian heresles (1.e., parties) not as the result of faction and strife, but of following individuals who admired Christianity while holding some discordant views (Origen Contra Celsus 3.12 [ANF, 4:469]). Conversely, Hatch points out, the Catholic tendency stressed the unity of the apostles; their tradition was not that of Peter, or James, or John, but of "the Ewelve" (see Edwin Hatch, The Influence of Greek Ideas and Usages upon the Christian Church: The Hibbert Lectures, $1888,2 d$ ed., ed. A. M. Fairbairn [London: Williams and Norgate, 1891], Pp. 316-17).

${ }^{1}$ Namely, the charismatic model of authority.

${ }^{2}$ That is to say, the leadership-of-office pattern of church authority. This model of authority is represented in the NT by the appointment of bishops or elders to be pastors and overseers of the local congregations (see, for instance, Acts 14:23; Phil 1:1). 
criterion identified thus far, a concrete nunn of orthodoxy had come into focus; that is, the teaching of the apostles. The documents of the $\mathrm{NT}^{1}$ as well as extra-canonical writings of the first two centuries $^{2}$ witness to the widespread acceptance of the authority of the apostles through whom the Lord's will was regarded to have been expressed. 3 That "the twelve'sn'4 authority remained unquestioned even after their death is attested, for instance, by the fact that the earliest known Church Order, the DIdact:e, bears the ticle "Teaching of the Twelve Apostles." Due to the authoritative status

Isee above, p. 32 , especially n. 3 .

2 As far as the non-canonical writings are concerned, one reads in 1 Clem 42:1-2: "The apostles recelved the gospel for us from the Lord Jesus Christ; Jesus, the Christ, was sent from God. Thus Christ is from God and the apostles from Christ" (Cyril C. Richardson, ed. Early Christian Fathers (New York: Macmillan Publishing Co., 1970], P, 33). Ignatius, bishop of Antioch, ranks the apostles with the Lord in Magn 7:1: "The Lord did nothing without the Father (either on his own or by the apostles)." He admonishes in Magn 13:1, "Make a real effort, then, to stand firmly by the orders of the Lord and the apostles." Likewise the letter of Polycarp, bishop of Smyrna, to the Philippians (6:3) exhorts: "Let us 'serve him with fear and all reverence,' as he himself has commanded, and also the apostles who preached the gospel to us" (This English version of Ignatius' and Polycarp's letters is also in Richardson, Early Christian Fathers). It is hardly surprising therefore that ca. A.D. 200, Serapion, bishop of Antioch, stated that "Peter and the rest of the apostles we accept as the Lord" (Sernzion, Libro de Evangelfo Petrl (PG, 5:1373, 1374]). The idea that the church's message rested upon the witness of the apostles to Christ was more fully elaborated by Justin's time (see, for instance, his Eirst Apology 66.3, and Dialogue with Irypho 103.8 [ANF, 1:185, 251]).

${ }^{3}$ See Bultmann, Theology, $2: 138-39$.

${ }^{4}$ Bultmann points out that the wiile "apostle" (a sent man, a messenger), which originally was accorded to all Christian missionaries, was narrowed down to include only "the twelve," and Paul, who was the only exception to this restriction (see Bultmann. Theology, $2: 105,139)$. 
reached by the apostles, their teaching was logically regarded as the fundamental norm of correct Christian belief.

The New Testament Canon as a notw

of orthodoxy

Apart from the question of apostolic authority, Paul's case might be regarded as an illustration of a further step in the development of classical orthodoxy. It seems clear that Paul's authority had rapidly become widely recognized, at least in the churches founded by him ( 1 Cor 9:2). Those early believers who had accepted the apostle's gospel ( 1 Cor $15: 1)^{1}$ soon faced a dilemma concerning the authentlclty of his letters. Already in Paul's lifetime there seems to have been some writings falsely attributed to hin in which the apostle rejected some teachings as incorrect (see 2 Thess 2:1-5). Paul was not alone here. The fact that several Christian documents were attributed, at times falsely, to other apostles, witnesses to the authoritative status that the latter had reached among the churches. Since Firistians regarded the teaching of the apostles chosen by Jesus as normative, their writings as well as those of their closer collaborators ${ }^{2}$ came to be considered, especially after the death of the apostles, the normative source of Christian doctrine.

Still, which among the apostles' writings were to be regarded as genuine and holding apostolic authority? Which ones

lFor references to "Paul's gospel" ("my gospel"), see Rom $2: 16 ; 16: 25 ; 1$ Thess $1: 5 ; 2$ Thess $2: 14 ; 2$ Tim $2: 8$.

${ }^{2}$ E.g., Mark and Luke. 
were authentic apostolic documents? This particular predicament would further increase from the second century on as the struggle between the mainstream Christian body and the marginal groups became more intense. Due to the authoritative status of the apostles, the authenticity and canonicity of the apostolic writings became almost symonymous. 1

Before the existence of an officially sanctioned New Testament Canon, 2 Christians were increasingly confronted with the issue of Identifying the books which were to be accepted as normative. $^{3}$ The available historlcal evidence shows that at first there

1John Knox, Criticism and Faith (New York: AbingdonCokesbury Press, 1952), pD. 66-67.

2 It must be remembered that, as far as we know, the first Christian who seems to have set limics to the documents which were to be considered as authoritative was the heretic Marcion, who spread his views in the middle of the second century (see, for instance, Hans von Campenhausen, The Formation of the Christian Bfble, trans. J. A. Baker [Philadelphla: Fortress Press, 1972], pp. 148ff; also Adolf von Harnack, History of Dogma, 7 vols.. trans. Neil Buchanan (New York: Dover Publications, 1961), 1:280-81). The first to name the twenty-seven books of the NT as exclusively canonical was Athanasius, the patriarch of Alexandria, in his 39 th Easter Letter of 367 A.D. (See Marie-Joseph Lagrange, HLstoire ancienne du canon du Noureau Testamenc, $2 \mathrm{~d}$ ed. [Paris: J. Gabalda, 1933], Pp. 134-36; Alexander Souter, The Text and Canon of the New Testament, 2d ed., rev. C. S. C. Williams [London: Gerald Duckworth \& Co., 1954], p. 171 .

${ }^{3}$ The contention has been made that each party was willing to accept as "canonical" only those books which served to support its views. Thus Michael E. Stone, professor at the Hebrew University of Jerusalem, suggests that in the formation of their canonical writings both Judaism and Christianity rejected material which was not in agreement with their orthodoxies, i.e., with the varieties "which became dominant and survived" (Michael Edward Stone, Scriptures, Sects and Vistons: A Profile of Judaism from Ezra to the Jewish Revolts (Philadelphia: Fortress Press, 1980], p. 53). In a similar vein, Kraft observes that mainstream Christianity wanted to accept the writings of the NT as authoritative for other reasons than just apostolic origin. He points out that some writings of 
was no unanimity on this point among the various centers of Christianity. 1 In the gradual process of the formation of the New

widely disputed apostolicity finally came to be included in the Canon--e.g., Hebrews, 2 Peter, Revelation--whereas others which also claimed apostolicity were not ultimately included--e.g.. the Gospel of Thomas, letters of Clement, letter of Barnabas. The "gnostic problem," for instance, Kraft holds, "provided a catalyst and also provided certain criteria for selection" (see Kraft, "The Development," pp. 51-52, 55).

Such a contention may find support in various historical facts. Marcion's canon, for Instance, can be considered minimalist. It consisted of no more than Luke's Gospel, with all seemingly Judaizing passages excised, and only ten Pauline epistles similarly edited. This was consistent with his rejection of the OT and of all writings which seemed to him infected with a Jewish outlook (see Tertulilan Gontra Marcion 4.4-5; 5 (ANF, 3:348-50, 429-474]). While Marcion was concerned to set the limits between his community and the larger Christian body--in a similar way as Irenaeus, for instance, and other orthodox Christians set a boundary which excluded Guostic groups from orthodox Christianity--several of the treatises found at the Nag hammadi library seem to indicate that some Gnostics were willing to draw connections between their movements and the larger Christian communities. Their maximalist approach led them to use alongside the canonical writings of the "orthodox," which they anyway edited, a mass of other craditions as well as poetical and subjective creations not employed by the former (see Pheme Perkins, "Gnosticism as a Christian Heresy," The Encyclopedia of Relizion [1987], 5:579; see also Theodor Zahn, "Canon of Scripture," NSchHerERY [1908], 2:395-96). The Muratorian canon was most probably written under Roman influence (c.200 A.D.), so it could reflect the theology of that sector of Christianity. There is no place in it for Gnostic literature, Marcion and Montanism, nor for such documents of Jewish Christian flavor as the Letcer to the Hebrews and the Epistle of James. However, there is room for an Apocalypse of Peter and. with some reservations, for the Shepherd written by Hermas in Rome. Yet, that the NT Canon is also the result of a sifting aimed at supporting a unilateral view of Christianity can be held only with difficulty due to the diversity-in the view of some even opposed and conflicting positins--represented by its documents. Since the events of the fourth century made the isolacion of segments of Christianity almost impossible, the resulting "ecumenical consciousness of the church overleaped all barriers and affected even the canon" (Zahn, "Canon of Scripture," p. 399). What we have therefore in the NT is "a remarkably wide spectrum of early Christian orientations which, however, shuns the farther extremes" (Johnston, "Orthodoxy and Heresy in the Biblical Period," p. 16).

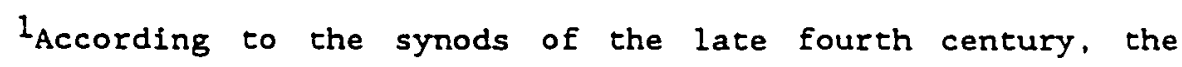


Testament Canon, 1 which took place essentially during the second and third centuries, the criteria for recognizing the canonical books as such $^{2}$ seem to have been both authenticity and apostolic origin, as

exact shape of the Canon of the NT still remained imprecise until the beginning of the fifth century (Zahn, "Canon of Scripture," p. 399). For the different lists of New Testament documents regarded as canonical by early Christian communities, see, for instance, Adolf von Hamnack, The Origin of the New Testament and the Most Important Consequences of the New Creation, trans. J. R. Wilkinson (New York: Macmillan Co., 1925), pp. 1-114, especially the Appendix II: "Forerunners and Rivals of the New Testament" (Ibid., PP. 169183). See also A. Souter, The Text and Canon of the New Testament, pp. 137-220; Oscar Cullmann. The Early Church; Studies in Early Christian History and Theology, ed. A. J. B. Higgins, trans. A. J. B. HIggins and S. Godman (Philadelphia: Westminster Press, 1956), pp. 39-54; Robert M. Grant, The Formation of the New Testament (New York: Harper \& Row, Publishers, 1965), pp. 148-80; Werner Georg Kümel, ed., Introduction to the New Testanent, trans. A. J. Mattill, Jr., 14th rev. ed. (Nashville and New York: Abingdon Press, 1966), PP. 334-358; $H$. von Campenhausen, The Formetion of the Christian Bible, Pp. 147-268; Bruce M. Metzger, The Early Versions of the New Testament: Their origin. Transmission, and Limitations (Oxford: Clarendon Press, 1977); and Charles F. D. Moule, The Birth of the New Testament, 3rd. ed. (San Franciscs: Haxper \& Row, Publishers, 1982), PP. 235-69.

$l_{\text {Regarding the formation of the Canon of the NT, in-depth }}$ studies and investigations were conducted during the $19 \mathrm{th}$ and the early 20th centuries. One may safely conclude that the New Testament is not the product of official assemblies, of concillar decisions, or of the studies of a few theologians (cf. Grant, Formation of NT, p. 10). Still, the affirmation that the Canon is not the product of the church but of the Holy Spirit needs qualification. The collection of the books of the NT was created by the church in the sense that, under the guidance of the spirit, the Christian communities chose the books which in their view adequately represented the legitimate teaching of the Lord and his apostles. The Spirit did not work alone, apart from the communities. Rather He acted in and through the church.

2 Both the fact that the church had to recognize its authoritative Scripcures through a process which lasted about four centuries and the considerations presented so far in our main text and footnotes pose the old problem of finding out whether it was orthodoxy that selected a canon of scriptures or whether certain scriptures shaped an orthodoxy. In other words, it must be decided which proposition is correct: either "the church created the Canon" or "the Scriptures created the church." In the understanding of 
weIl as the IIturgy of the church and the content of the books themselves. 1

In this way, simultaneously and in correlation ${ }^{2}$ with the emphasis on the doctrine of the church as apostolic, another norm of c!assical orthodoxy was naturally dereloping with the fixing of the list of the neo-testamentarlan documents regarded as the definitive standard of Christian doctrine.

The importance of recognizing a corpus of writings as a norm of true belief can hardly be exaggerated. In fixing and accepting the NT Canon, the church ${ }^{3}$ was officially setting the boundaries of

conservative Protestants, the idea that the Canon is not the product of the church means that it was not the church as a human community which attributed inspired value to some writings. In their view the church was led by the Spirit to recognize the intrinsic inspired nature and authoritative status of those writings. In this way the authority of God's word is prior to and above that of the church. On the contrary. In Roman Catholic textbooks it is affirmed that the Catholic Church is the mother of the New Testament: "If she had not scrutinized carefully the writings of her children, rejecting some and approving others as worthy of inclusion in the canon of the New Testament, there would be no New Testament today" (John A. O'Brien, The Faith of Millions: The Credentials of the Catholic Religion [Huntington, Indiana: Our Sunday Visitor, 1974], p. 127). More scholarly Cathollc works, however, hold that the inspired nature of the canonical books "does not consist in the fact that the Scriptures have been accepted as canonical by the Church" (Karl Rahner, Inspiration in the Bible, 2d rev. ed. [Fribourg: Herder; and London: Burns \& Oates, 1964], p. 11). As to the question of which is first, the church or the Scriptures, in my opinion it may well be that the "either or" is a false dilemma.

In connection with the last criterion, i.e., the content of the books, R. M. Grant observes that the fact that the Gospel of Thomas, for instance, was not treated as canonical indicates that the bulk of early Christian theology was not Gnostic (see Grant, Formation of NT, P. 180).

2 Ibid., p. 9 .

${ }^{3}$ From what has been discussed above, it should be clear that by "the church" we mean the whole community of Christian believers, 
what it had already acknowledged in practice as the written source and standard of legitimate Christian doctrine. Since the church had accepted a written norm, its beliefs and preaching--not to mention its liturgy, structure, and practices, in genessl its whoie iffe.. were bound to be constantly checked by that standard. Besides and of utmost importance for our study, delineating the limits of the NT Canon meant that the living and Spirit-led activity of discernment of correct teaching ${ }^{1}$ would progressively give place to the doctrinal authority of a set of sacred writings. To be true, this set of writings was belleved to contain the kernel of the very same apostolic living proclamation and teaching. ${ }^{2}$ This means that the principle lying behind the establishing of the NT Canon was that the tradition of the apostles was regarded as normative for all subsequent tradition of the church.

A historical-theological analysis of the development of classical orthodoxy shows that the controversies between parties claiming to hold to the truth $^{3}$ served as the catalyst for the

not merely its leaders. This is the sense in which I use the term in this whole section dealing with the NT Canon.

$1_{\text {see above, pp. 31-32. }}$.

2 This apostolic living proclamation and teaching can also be technically referred to as the "living tradition" of the apostles. For further discussion on the relationship between the living and the written apostolic tradition, see below, pp. 55-59.

In addition to the controversies concerning the apostol. icity of Paul, we can mention the controversies between those who later began to be called orthodox, catholic Christians in their confrontation with syncretistic Gnosticism, sectarian Marcionism, enthusiastic Montanism, and the like. Interestingly enough, the Montanist movement (C.175 A.D.) advocated the revelational criterion by contending that a new period of prophecy had already opened, 
emergence of the two related norms of Christian truth which we have Identified so far, namely, the teaching of the apostles and the Canon of the New Testament. 1 These norms may be regarded as the concrete expression of the revelational criterion of orthodoxy. They are indeed the first norms of orthodoxy clearly identifiable in the history of Christian theology and, as such, they may be considered the authoritative original sources ${ }^{2}$ of the Christian message.

We cannot overlook the fact that the establishing of these two norms means that in their proclamation and teaching the early Christians looked back to a unique event in the past, namely, God's revelation in Jesus Christ. ${ }^{3}$ The revelational nature of the Christevent and the authoritative witness of the apostles to Christ were regarded as so fundamental to the Christian message that a retrospective attitude, a constant "return to the sources," in the church's definition of correct belief and teaching was considered of the essence of the kerygmatic dimension of its mission.

against the mainstream church's position which regarded the age of revelation as closed with the death of the last surviving apostle and the canon of the NT as completed.

$1_{\text {Namely, the }}$ 1ist of NT documents regarded as legitimately containing the teaching of Jesus and the apostles.

2 The expression "original sources," ever, though redundant ("source" has already the semantic connotation of origin), is intended to designate the historically or chronologically primordial sources of Christian doctrine.

3ne mark of all orthodoxy is that truth has been given somewhere in the past," remarks Kenneth Cauthen (Systematic Theology: A Modern Protestant Approach [Lewiston, New York; Queenston, Ontario: The Edwin Mellen Press, 1986], p. 16). 
The possession of a written norm of Christian truth had at least two important consequences. First, the unalterable nature of a written source of doctrine made it possible for the church to have a reliable tool for checking its own orthodoxy and orthopraxis. 1 To the extent that the church would indeed submit itself to the normativity of the apostolic witness as recorded in the Canon, the latter would outrank it in authority. This statement brings to the foreground the question of the church's authority. A second consequence of having a written norm of orthodoxy is precisely that the authority of the church and the authority of the canon of Scriptures found themselves in a state of potential tension. The latter was openly manifested in the Tradition-Scriptures controversy at the time of the Protestant Reformation. The authority of the Canon--which, the church confessed, had been recorded under the Inspiration of the Holy Spirit--and the authority of the church-which Christians regarded as derived directly from the Lord and assisted by the charism of the spirit--set up two secmingly contradictory norms for the definition of correct belief and teaching. The identification and description of these norms as well as the criteria and theological issues lying behind them is our task in the following pages.

The Principle of Tradition and the Ecclesiastical Criterion of Orthodoxy

With the passing of time, the idea of tradition ( $\pi \alpha p \alpha \delta$ oris)

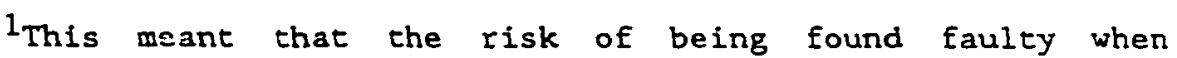
measured against that norm was an open possibility for the church. 
in the technical sense of authoritative transmission of the Christian message ${ }^{l}$ acquired increased relevance for at least two reasons. The very fact of the permanence of the church in the world through several generations created the conditions for the establishing of processes, structures, and mechanisms of transmission of its message. Besides, the struggles of the church against heresy gave increasing importance to the concept of tradition from the second century onwards.

As it occurred with the concept of a Canon of the NT scriptures, so the idea of an oral tradition was not exclusive of the mainstream church. Interestingly enough, these notions emerged for the first time among non-orthodox Christians. 2 The church's elaboration on the concept of tradition was indeed a reaction on its part to the gnostic claim of possessing a secret mapáoorls. ${ }^{3}$ In

Isee above, p. 38, n. 1. Jaroslav gelikan observes that "tradition" refers simultaneously to the process of communication of doctrine and to its content. It means "the handing down of Christian teaching, . . . but it also means that which was harded down" (Pelikan, Catholic Tradition, p. 7). Tracition, remarks he, "Is the living faith of the dead; tradicionalism is the dead faith of the living" (ibid., p. 9).

Since in Christianity salvation rests upon the proclamation of the Word (Rom 10:13-17; Mark 16:15-16), the transmission of the gospel brought by Jesus Christ from generation to generation (John 17:20) is of the essence of the church. We may thus safely affirm that Christianity cannot exist in its historical dimension without tradition.

2 Thus Hans von Campenhausen notes that the view of a public line of successicn-tradition was formulated by the mainstream church against the contention, First raised by Gnostics, of a secret oral tradition (H. F. von Campenhausen, Kirchliches Ame und geistliche Vollmacht in den ersten dref Jahrhunderten (Tübingen: Verlag J. C. B. Mohr, 1953], pp. 163-94). As to tine influence of the heretic Marcion in the formation of the NT Canon, see above, p. 44, n. 2 .

$$
{ }^{3} \text { See, for instance, Josef Ratzinger, "Primacy, Episcopate, }
$$


the principle of a public and uninterrupted line of tradition (i.e.. the principle of succession-tradition ${ }^{1}$ ), the point at issue was the falthful continuity of genuine Christian teaching.

Toward the second half of the second century, the struggle between the various Gnostic parties and what began to be called Catholic Christianity ${ }^{2}$ grew more intense. Since each party could be charged with interpreting the same Scriptures to its own ends, a hermeneutical criterion was much in need. The Gnostics claimed to have access to an alleged "secret apostolic tradition"3 which expounded the true meaning of Christ's teachings. In the context of this controversy in which both parties appealed to the same authority, i.e.. that of the apostles, ${ }^{4}$ non-Gnostic Christians felt

and Apostolic Successlon," in Karl kanner and Josef Ratzinger, The Episcopate and the Primacy (New York: Herder and Herder, 1963), $p$. 50 . earlier.

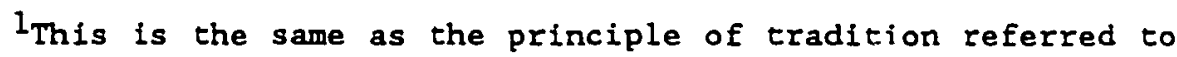

2 The first appearance in Christian literature of the phrase "the Catholic church" occurs in Ign. Smyr 8:2 (c. 107 A.D.), where it stands for the universal church in contrast to the local congregation (see Richardson, Early Christian Fathers, pp. 112, 115). In the document known as the "Martyrdom of Polycarp" there are references to "the whole Catholic church throughout the world" $(8: 1)$, and to "the bishop of the Catholic church in Smyrna" (16:2). (See ibid., pp. 151, 155). It is the Muratorian canon (c. 200 A.D.?) which specifically mentions the "Church catholic" as distinct from the heretical congregations. (For English translation of the Muratorian Fragment, see Theodor Zahn, "Muratorian Canon," NSchHerERK, 8:56; see also ANF, 5:603-604).

${ }^{3}$ Irenaeus charges the heretics with asserting that the truth cannot be extracted from the Scriptures "by those who are ignorant of tradition." The Gnostics alleged, according to Irenaeus, "that the truth was not delivered by means of written documents, but viva voce" (Irenaeus Adversus haereses 3.2.1 [ANF 1:415]).

${ }^{4}$ That all parties appealed to the apostolic teaching as the 
compelled not only to determine more clearly the limits of the canonical Scriptures but also to stress the importance of "an oral tracition handed down openly" from Christ, via the apostles, from generation to generation until their time. 1 Thus, an increasing importance began to be given to the tradition preserved "in the Christian churches of apostolic origin." 2

authoritative tribunal of Christian doctrine is witnessed, for instance, by the Gnostic Ptolemaeus in his Letter to Flora. Discussing the mystery of the origin of both the demiurge and the devil from one incorruptible and good first principle, Ptolemaeus writes: "For, God willing, you will learn later about their origin and generation, once you are granted the apostolic tradition, which we too have received by succession, together with judging all matters by the doctrine of the Saviour" (Ptolemaeus Ad Floram epistola [PG, 7:1289, 1291, 1292]; cf. Robert M. Grant, ed., Gnosticism: A Source Book of Heretical Writings from the Eacly Christian Perlod [New York: Harper \& Brothers, 1961], P. 190). Gilles Quispel comments that Ptolemaeus received his reaching essentially from Valentinus, who in turn based his own on the doctrine of Theudas, disciple of Paul. Quispel notes that this one was, however, a secret tradition (G. Cuispel, Ptolémée, Letre a Flora: analyse, texte crfthque, traduction commentaire et index grec (Paris: Les Editions du Cerf, 1966], p. 104).

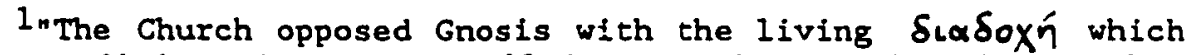
is . . traditio and successio all in one: the word bound up with a witness, and the witness bound to the word" (Ratzinger, "Primacy, Episcopate, and Afostolic Succession, p. 50). The church formulated the principle of an oral plus a written tradition, observes Ratzinger, "precisely to defend herself against the gnostic allegation of a $\pi \alpha p \alpha \delta \delta \sigma l s$ d́ypacyos (an unwritten tradition). The

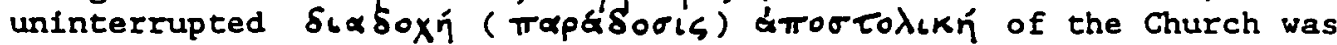
for the early anti-gnostic theologians precisely the proof that

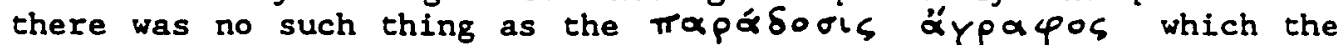
Gnostics preached iat least in the form alleged by the Gnostics)" (ibid.).

2Irenaeus, for instance, argues against the Gnostics and other heretics that the churches that stood in succession with the apostles were the recipients of the true tradition which originates from them (Irenaeus Adversus haereses 3.2.2 [ANF, 1:415]). Similarly, Tertulliar writes that the true Christian faith is preserved in the apostolic churches (Tertullian Praescriptione haereticorum 20 (ANF $3: 252$ ]). 
In this way, the principle of authority and the principle of tradition merged and found expression in the "ecclesiastical criterion" of Christian truth. 1 According to the classical understanding of this criterion, the true Faith was preserved in the church and in the church only, 2 to which belonged both the canonical Scriptures and the authentic oral tradition of the apostles.

Though to lessen the value of the revelational criterion or the normativity of the Canon may have not been intended, at the time of the early fathers and the apologists an increasing importance was given to the ecclesiastical criterion of orthodoxy. The Christian communities that stood in succession with the apostles were regarded as the recipients of the "precious deposit" 3 of the uniform teaching of the church, which it preserved essentially intact. 4

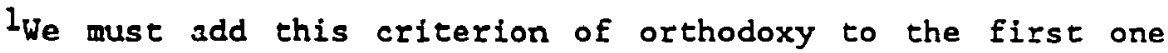
identifled earlier, namely, the revelational criterion.

2 "Where the Church is, there is the Spirit of God; and where the Spizit ct God is, tnere is the Church,. . . but the Spirit is truth," remarks Irenaeus (Adversus haereses 3.24.1 (ANF 1:458]). He then strongly asserts that those who do not partake of the church "are neither nourished into life from the mother's breasts, nor do they enjoy that most limpid fountain which issues from the body of Christ; but they dig for themselves broken cisterns out of earthly trenches, and drink putrid water out of the mire, fleeing from the falth of the Church lest they be convicted" (ibid.).

${ }^{3}$ The doctrine of the depositum fidel which was elaborated by the Roman Catholic Church in the Middle Ages may be considered as a later development of this view held by Irenaeus. Its basic assumption is that in the apostolic age the church was entrusted with a certain treasure of revealed truths, none of which was to be lost, and to which no new revelation was to be added. As defined by the Second Vatican Council, the deposit of faith consists of the canonical Scriptures and sacred tradition (see Constilution on Divine Revelation, art. 10).

${ }^{4}$ See Irenaeus Adversus haereses 3.24 .1 (ANF, 1:458). The
church's conviction that it preserved the deposit of faith 
No developmental theory was consciously proposed in general by the ante-Nicene fathers. On the contrary, they regarded any innovation as basically a perversion of the original Christian truth, 1.e., "heresy." So Tertullian maintained that the Catholic church had received its teaching as well as its canonical Scriptures directly from the apostles at a time when all heresies had not yet arisen, and that it had preserved the original truth faithfully. 1 By the same token and about one century later (c. 325 A.D.), Eusebius of Caesarea contended that primitive Christianity was uncontaminated by error and that heresy arose in the church as an Innovation after the death of the apostles. 2

Oral tradition as norm ef orthodoxy

We should not lose sight of the fact that in the first century there seems to have been no clear distinction between the oral and the written forms of the apostolic tradition. Toward the second half of the second century, however, the distinction between

essentially intact found classical expression in the dictum of Vincent of Lérins (d. after 434) who asserted in his controversy against Augustinian p:idestinarianism that the true Christian doctrine is that which has been believed "ubiaue, semper, ab omnibus," everywhere, always, by all (Vincent of Lérins CommonitoFium primum 2 (PL, 50:640]).

$1_{\text {Hans von Campenhausen stresses the importance that this }}$ argument of Tertullian's praescriptione haereticorum has had for the later development of Roman Catholicism in his The Fathers of the Latin Church, trans. Manfred Hoffmann (London: Adam \& Charles Black, 1964), p. 24 . 30, n. 2 .

${ }^{2}$ Eusebius Ecclesiasticae historiae 3.32.7-8. See above, $p$. 
the Scriptures and the oral tradition ${ }^{i}$ of the church as coordinate means of transmitting the apostolic message came to be more clearly appreciated. ${ }^{2}$ Still, at that point of time, there appear to have been no controversy as to the supremacy of one over the other. There was rather an interplay between them. ${ }^{3}$ The oral tradition, which was condensed in the "rule of faith, "4 was regarded as true because it was contained in Scripture. Besides, both the canonical Scriptures and the rule of faith were true because they were considered as conveying the reaching of the apostles.

Thus, next to the NT Canon, Christlans like Irenaeus (c.135c.202 A.D.) and Tertullian (c.150-c.230 A.D.) stressed the importance of an additional norm of orthodoxy. It was what Irenaeus called the oral "canon of truth"5 or, in the words of Tertullian.

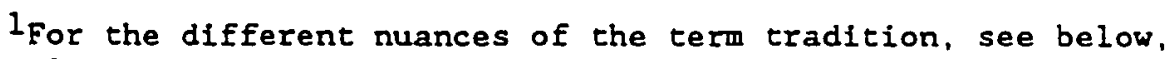
p. 59, n. 1 .

${ }^{2}$ For a relevant discussion of this issue, see Kelly, Early Christian Doctrines, pp. 31-41.

3 Regarding the emergence of the notion of tradition in contradistinction from the Scriptures, Cardinal Ratzinger affirms, from a Roman Catholic perspective, that the church did not intend to canonize an oral tradition of doctrine as something parallel to the Scriptures. In fact, notes he, "Christians had already formulated the principle of successio-traditio before they yet understood the New Testament as 'Scripture'" (Ratzinger, "Primacy, Episcopate, and Apostolic Succession," p. 49). He further asserts that in this way the Canon of the NT, i.e.. the collection of writings which concerned the New Covenant and were acknowledged as apostolic already before being officially fixed in a closed corpus, must be understood as a materialization of that tradition (ibid.).

"For further reference to the meaning of the "rule of faith" or the "canon of truth," see the discussion below, pp. 56-59.

$S_{B y}$ "the canon of truth" Irenaeus meant a condensed summary of Christian fundamental beliefs--fixed in its content, not in its wording--in whici the church's oral teaching, in principle 
the "rule of faith." Being the concrete expression of the ecclesiastical criterion of orthodoxy, this oral norm was regarded as preserving the apostolic testimony in its original shape, thus serving as the indispensable key to interpret the Scriptures.

In arguing with heretics, such a norm was indispensable, wrote Tertullian. No appeal could be made to the NT Canon alone, ${ }^{2}$ since the heretics either mutllated the text or perverted the

independent of written documents, found expression (see Kelly, pp. 35-39). Although the church is dispersed all over the world it is one church, which has received "the faith" from the apostles and their disciples, held Irenaeus. Quoting from the canon of truth, he affirmed that the content of the tradition of the church is one and the same in every language and nation (Adversus haereses 1.10.1-2 and 1.22.1 [ANF, 1:330-31, 347]). In Demonstratio apostolicae praedicationis 3, Irenaeus elaborates on the Christian's duty of keeping "strictly, without deviation, the rule of faith." In Demonstracto 6 , he refers to "the order of the canon of our faith, the foundation of the building, and the consolidation of a way of life" (see English translation of Demonstratio (or Epideixisl) in Joseph P. Smith, ed., St. Irenaeus: "Proof of the Apostolic Teaching", Ancient Christian Writers, The Works of the Fathers in Translation, no. 16 (New York: Newman Press, 1952]).

1The "rule of falth" (requla fidel or regula veritatis) was for Tertullian what the "canon of truth" was for Irenaeus. He did not mean that the "rule" was a formal creed but rather a piece of unwritten tradition which made explicit the cardinal truths about the Father, Christ, and the Holy Spirit. It had been handed down by Christ himself through the apostles and pointed the way to the correct interpretation of Holy Scripture (see Kelly, Early Christian Doctrines, Pp. 39-41). Tertulilian quotes from the "rule" or alludes to it in Praescriptione haereticorum 13.37 (ANF, 3:249); also in De virginibus velandis 1; Adversus Praxeam 2; and Apologeticus adversus gentes 47 (ANF, $4: 27 ; 3: 598,3: 51-52$ ). For further comment on Tertulitian's rule, see Anne Fremantle, ed., A Treasury of Early Christianity (New York: Viking Press, 1953), pp. 343-45.

2Tertullian Praescriptione haereticorum 19 (ANF, $3: 251$ ). See also $T$. Herbert Bindley, ed., Tertulliani, "Praescriptione Haereticorum ad Martyras: Ad Scapulam" (Oxford: At the Clarendon Press, 1893); and R. F. Refoule and P. De Labriolle, Tertullien: "Traité de la prescription contre les hérétiques (Paris: Les Éditions du Cerf, 1957). 
meaning of the scriptures. 1 Therefore, in order to get to the truth, It was deemed necessary to have both the Canon (i.e., the true Scriptures) and the key for its right interpretation. This key belonged exclusively to the church, which was the only possible place where the apostolic testimony was preserved. 2

Some have deciuced that both Irenaeus and Tertullian made the unwritten teaching of the church, as expressed in the "rule of faith," a norm more nearly ultimate than the canonical Scriptures. The two fathers, however, do not seem to have wanted to do so. For them the function of both the NT Canon and the unwritten tradition in the transmission of God's truth is comparable to that of one's feet in one's activity of walking: neither is superfor to the other. They considered that both the oral teachings of the church and its written tradition were true because they conveyed the apostolic message and witness to Christ. In their struggle against che Gnostics neither an oral teaching alone (the Gnostics claimed to possess a secret apostolic tradition which was more complete and accurate) nor the NT Canon alone (the Gnostics simply interpreted it differently) seemed to them to be an effective court of appeal.

The fact remains, however, that in the long run the written fixity of the Scriptures came to constitute a more dependable means of preserving the apostolic message than the shifting nature of oral

${ }^{1}$ Tertullian Praescriptione haereticorum 17 (ANF, 3:251).

${ }^{2}$ Tertullian claimed that both the authentic Scriptures and the true unwritten tradition "will be found where the true Faith is" (Praescriptione haereticorum 19 (ANF, 3:251-52]), namely, in the "apostolic" churches (ibid. 20 [ANF, 3:252]). 
tradition. It is precisely at this point that the latent tension mentioned earlier between the Scriptures and the living tradition as norms of orthodoxy may be seen in all its significance. This tension would prove to be most acute whenever a clear incompatibility appeazed betsean the positions of the living teaching authority of the church and the flxed scrip--ral norm. To solve difficulties of this nature, three main possibilities seemed to be open for Christians. They could opt for attributing normative preeminence to efther the NT Canor or the living tradition. A third possible attitude was to attempt to harmonize both norms of Christian truth by means of a specific hermeneutical principle.

The principle of succession-tradition has a two-fold dimension. To the above-discussed concept of tradition ${ }^{1}$ one must add now the notion of succession, and for this matter we should bring into focus the question of the church's teaching authority mentioned earlier without explicit definition.

The pronouncements of the Magisterium as a norm of orthodoxy

In addition to the notion of a publicly preserved apostolic tradition, the doctrine of the apostolic succession ${ }^{2}$ was also

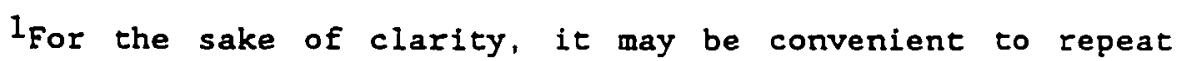
here that the term tradition conveys different meanings ( $c f$. above, p. $38, n$. 1 ; and p. 51, n. 1). It refers basically to the transmission of the Christian message. It may also designate, specifically, the unwritten doctrine of the church (oral tradition) in contradistinction from the Bible. Some use the expression "living tradition" to designate the permanent teaching activity of the church. As it may be noticed, in none of these cases "tradition" has the common sense of "custom."

2 The doctrine of the apostolic succession of the episcopacy 
formulated hy the mainstream church as part of its response to Gnostics in the polemics of the second century. 1 In this context, it seemed expedient to restrict the living teaching authority of the church, once shared by all its members, to the teaching of the bishops. The authoritative status reached by the apostles brought about the acceptance of the authority of the bishops by the churches. ${ }^{2}$ The bishops were increasingly viewed as the successors of the apostles, thus becoming the living witnesses and guardians of the falth. ${ }^{3}$ They exercised the magisterium ${ }^{4}$ or teaching authority

is of the essence of the Roman Catholic Church. At the end of article 20, after considering the nature of the apostles' ministry, the Second Vatican Council's Dogmatic Constitution on the Church reads: "This sacred synod teaches that by divine institution bishops have succeeded to the place of the apostles as shepherds of the Church, and that he who hears them, hears Christ, while he who rejects them, rejects Christ and him who sent Christ" (see The Documents of Vatican II. In a New and Definitive Translation with Commentaries and Notes by Catholic. Protestant and Orthodox Authortlies, ed. Walter M. Abbott, trans. Joseph Gallagher, with an Introduction by Lawrence Cardinal Shehan [New York: Herder and Herder, and Association Press, 1966], p. 40. Quoted henceforward as Docs of Vatican II).

1see Von Campenhausen, Kirchliches Amt, pp. 163-94. In his concern to neutralize the heretical movements that were leading the church to schism, Ignatius writes: "Do nothing apart from the bishop; . . value unity; flee schism; imitate Jesus Christ as he imitated his Father" (Ign. Phil 7:2 [Richardson, Eacly Christian Fathers, PP. 77, 1101).

${ }^{2}$ The NT testifies to the appointment of bishops or elders by the apostles to be pastors and overseers of the local congregations (e.g., Acts $14: 23 ; 20: 28$; Phil $1: 1 ; 2: 25$; Col 4:11). Patristic 1iterature witnesses to the increasing emphasis on the apostolic authority of the bishofs toward the end of the first century. Thus, 1 Clem 42:4, for instance, affirms that the apostles "preached in country and city, and appointed their first converts, after testing them by the spirit, to be the bishops and deacons of future believers."

${ }^{3}$ See Ratzinger, "Primacy, Episcopate, and Apostolic Succession," pp. 46-47. See also Pelikan, Catholic Tradition, pp. 118-19; 
whenever the normative Scriptures needed interpretation in addressing particular aspects of a particular historical situation. In this way, it became increasingly common that by "the teaching authority of the church" what was referred to was indeed "the reaching authority of the bishops."

Disputes attempting to determine correct belief and teaching--the first important ones concerning Christology and the Trinity--began to be discussed in councils where, primarily, the bishops gathered together. The results crystalized in creeds, and the defeated party was considered "heretic" in the technical sense of holding false teaching or error. 1

and von Campenhausen, Kirchliches Amt, pp. 163-194. That the bishops succeeded the apostles and were endowed by the Spirit with a special charism was dogmatically taught by the First Vatican Council (see Denz, 960) and confirmed by Vatican II (see Lumen gentium, arts. $18-20$ ).

${ }^{4}$ The Latin term magisterium refers basically to the teaching role and authority of a person, a group of persons, or an institution (cf. Francis A. Sullivan, Magisterium: Teaching Authority in the Catholic Church (New York: Paulist Press, 1983), p. 24). For the history of the term, see Yves Congar. "A Semantic History of the Term Magisterium," in Charles E. Curran and Richard A. McCormick, eds., Readings in Moral Theology No 3: The Magisterium and Morality (New York: Paulist Press, 1982), Pp. 297-313. Its theological significance (i.e., the magisterium of the church) is discussed later in this chapter. At this juncture, however, we may note that the term is generally used in two different ways. Hence I write in this dissertation of the magisterium as the teaching activity of the church, and of the Magisterium as the ecclesiastical college of Roman Catholic bishops in communion with the Pope. Due to its frequent use in this dissertation and for reasons of convenience the term will be no longer underlined.

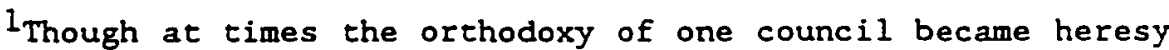
for a later one, and vice-versa. For instance, the Council of Ephesus (431) condemned Nestorius' sharp distinction between two natures in Christ. Another council in Ephesus (449) vindicated Eutyches' monophysitism and condemned any reference to two natures after Christ's birth. The Council of Chalcedon (451) rejected 
The ecclesiastical magisterium ${ }^{1}$ scon came to be regarded as a fundamental element in the understanding of orthodoxy. This means that the ecclesiastical criterion of Christian truth found further expression in the pronouncements of the Magisterium as norm of orthodoxy. Accordingly, the pneumatic-charismatic pattern of ecclesiastical authority would begin to give way gradually to a sacramental leadership of office. ${ }^{2}$ As a result the leaders of the church no longer based their legitimacy exclusively on the content of the message they proclaimed, but on the claim of having received a mandate from Jesus througin apostolic succession. in other words, the norm for doctrinal correctness (orthodoxy) was shifring froul the revealed content of the doctrines (1.e., the teaching of the apostles as recorded in the NT Canon) to the validity of the teacher's office, ${ }^{3}$ even though this shift may not have been perceived by all at the time.

This change of emphasis consisted indeed in the historical shift from a revelational concept of authority ${ }^{4}$ to an ecclesiastical

monophysitism and defined as orthodox the position which teaches two natures coexisting in one person.

IUnderstood as the teaching authority of those bishops who could prove to stand in succession with the apostles.

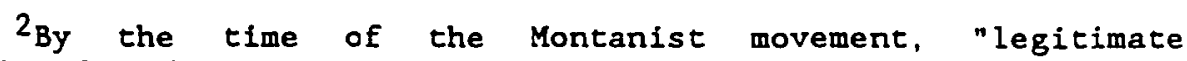
ordination had become more important than spirit-filled ecstasy." notes Kraft ("The Development," p. 55).

3 wilken underlines that instead of asking, "What is the truth?" Christlans began to $15 k$, "Who preserved intact the apostolic tradition?" (Wilken, The Myth, p. 42; cf. August Bernhard Hasler, How the Pope Became Infallible: Pius IX and the Politics of Persua: sion [Garden City, New York: Doubleday \& Company, 1981], p. 34).

"The "revelational" concept of authority points to the fact 
one, 1 a change which was of major importance for the development of the concept of ortiodoxy. It would also prove to be decisive for the character and self-understanding of the church, especially when Christianity became the official religion of the Roman empire. This shift in the criceria of orthodoxy meant that the lateer had begun to be understeod more and more in terms of the officially approved variety of belief. $\overline{2}$

From what we have seen thus far it appears that already by the mid-thled century, mainstraain Christianity had three basic norms of orthodoxy: (1) A rather well-defined Canon of Scriptures, in which the norn of the apostolic teaching was crystalized; (2) a body of post-apostolic or extra-biblical tradition, first represented by the oral requla fidef, the creeds, and then by the written conciliar statements of belief; and (3) the pronouncements of the episcopal Magisterium. ${ }^{3}$ These norms were the concrete expression of the two leading criteria of orthodoxy held by Christians at that time: the

that divine revelation--which is the origin of theological knowledge--was recognized in the early church as having intrinsic weight for prescribing faith and morals. For the orthodoxy of Christian doctrine this means that the emphasis was put on the content of the church's message.

IThe "ecclesiastical" concept of authority assumes that theological knowledge has an ecclesial dimension; the fact is stressed that the recipient and mediator of revelation is the church. For the orthodoxy of Christian doctrine this means that the emphasis was being put on the church (specifically, upon the episcopacy) as the agent transmitting the Christian message.

2 On the meanings of the term orthodoxy, see above. "Introduction," pp. 5-8.

3In Harnack's words, the apostolic "rule of faith," the Canon of Scripture, and the apostolic office of bishops "form a strict unity" (Harnack, Ortgin of the NT, p. 105). 
revelational and the ecclesiastical. These criteria consist, respectiveiy, in the notions that legitimate Christian doctrines had been delivered by divine revelation and that they were preserved in the church. In other words, Christian orthodoxy has a revealed origin and an ecclesiastical continutty.

\section{Orthodoxy and Heresy in the Post-Nicene and Medieval Church}

The emphasis increasingly put over the ecclesiastical criterion of orthodoxy in the ante-Nicene church would have specific theological interpretations during the long period comprising the time of Constantine to the 15th century. This was a perior of ecclesiastical consolidation. The support that the Roman empire gave to Christianlty after the conversion of Constantine ( 312 A.D.) was the cause not only that this religion eventually became the official religion of the koman empire, but also that it made mainstream Christianity the only legitimate form of Christianity in existence in the Roman world. As a result, dissenters began to be disfellowshipped and persecuted as enemies of the church and the state. Under such conditions, the eccleslastical criterion expressed in the increasingly accepted normativity of the pronouncements of the Magisterium brought forth two theological issues which bear upon the development of classical orthodoxy. They are the "unity" and the "infallibility" of the dogmatic teaching of the church.

${ }^{1}$ As noted before (see above, "Introduction," Pp. 2-2) the term "dissenters" designates those who think differently. 
The Issue of the Unity of the Church and Its Doctrine

With the establishment of Christianity as the religion of the state, things changed in the church, including the concept of orthodoxy. To begin with, the offices of the church were altered in their nature, and "a church hierarchy grew up that corresponded to the stats's." Following the imperial model of government, Christians came to accept the idea of having a centralized govermment which could secure the unity of the universal church. In the West the hegemony of the bishop of Rome began to emerge giving birth to the papal system of the Roman Catholic Church.

Various factors explain the cmphasis put on the unity of the church at that time. In the first place, there was the idea that salvation could be found only where the true Christian tradition was preserved, 1.e., in the churches that stood in succession with the apostles. To Cyprian bishop of Carthage (248-258 A.D.) already, it was evident that only those within the universal church could be saved. 2 If the church was such an instrument of salvation, it was imperative that its unity be preserved. ${ }^{3}$ Church unity, he argued, was to be found in one's unity with the bishops and in the unity of the bishops with one another. ${ }^{4}$ This way of reasoning gained momentum from the fourth century on.

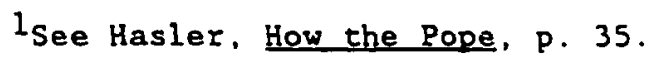

2 See Cyprian Epistles $73.6 ; 75.2$ (ANF, 5:388, 398).

${ }^{3}$ See, for instance, Cyprian Epistles $75,1,4,5,8$.

${ }^{4}$ See Cyprian De unitate ecclesiae (ANF, $5: 421-29$ ). 
Apart from the purely religlous or ecclestastical concerns. religious unity was considered by Christian emperors to be an indispensable element of polftical and social stahility. 1 Their at times zealous persecution of dissenters was generally approved by the bishops, 2 wino saw in the imposicion of doctrinai unity a convenient means of overcoming in their struggle against those whom they regarded as schismatics and spreaders of false doctrine.

In this way, religious and political interests merged and the ecclesiastical criterion of orthodoxy began to produce the medieval form of the institutional church. Religious and political concern for Christian unity, added to the growing power of the Magistertum as the agent transmitting the apostolic teachings and interpreting the content of the Canon, fostered the emergence of a rfgidly unified dogmatic system.

The increasing importance placed upon the ecclesiastical criterion of orthodoxy described above ${ }^{3}$ could not leave the content of the Christian proclamation and teaching unaffected. A shift in the understanding of orthodoxy took place. During the first two centurfes of Christian history, the leading concern regarding the antithesis of orthodoxy-heresy had been in regard to the definition and preservation of correct belief and teaching. The concept of

$1_{\text {Joseph Lecler and Marlus-François Valkhoff, Les premiers }}$ défenseurs de la liberté religieuse, 2 vols. (Paris: Les Éditions du Cerf, 1969), 1:15.

2 Ibid., p. 17.

${ }^{3}$ Namely, that Christian truth was preserved in the "apostolic" churches alone. 
orthodoxy, though the term was not widespread in those days, was essentially agreement with truth. 1 Affected by the institution. alization of the church delineated above, and by the emphasis on the ecclesiastical crieterion and norms of Christian truth, this concept gradually acquired a different meaning from the third century, that of agreement with the teachings of the established church. This was a significant departure from its earlier sense. The leading interest, as far as the orthodoxy-heresy issue was concerned, had increasingly become the preservation of the unity of the institutional church. To achieve this objective, unity of doctrine was indispensable. Since orthodoxy was now regarded as agreement with the officially approved teachings, any attempt at diversity or pluralism in doctrinal understanding was labeled heresy.

This should not be understood to mean that there was no concern for unity in the early years of church history, nor that the revelational criterion of orthodoxy and its related norms-i.e., the apostolic teachings and the Canon--were disregarded in the postNicene period. However, a shift of emphasis had occurred both in the meaning of orthodoxy-and-heresy and in the criteria and norms of doctrinal correctness. The orfiginal criterion and norms of orthodoxy were absorbed by and interpreted in submission to the

In harmony with the theory of truth prevalent in those days. Christian truth was understood in the post-apostolic church as the correspondence between the concepts in the mind of the cognoscent subject and a transcendent, unchanging, and absolute reality which had been made known through divine reveiation. we shall see later (see below, pp. 96-98) that this view of the early fathers is currently regarded as the result of their philosophical presupposition concesning the structure of reality. 
ecclesiastical criterion and norms. Though the church had long recognized the normativity of the NI Canon, the degree of diversity and the Christian Iiberty reflected in the New Testament tended both to disappear from its life.

A logical consequence of this institutional and theological development toward unification and in detriment of diversity sosn appeared in the life of the Christian community. After the Council of Nicsea ( 325 A.D.) and in lits alliance with the state, the church was led to treat the vlews which differed from its official doctrines as the concern not only of theology but also of civil law. Heretics became the object of legal penalties. ${ }^{1}$

Since it meant falling away from the unity of the faith of the church, heresy was regarded as a grave crime in the ancient church. ${ }^{2}$ Any internal attempt at dividing Christian unity was treaced as an infectivum vitium which, for the sake of the superior interests of Christianity and the state, had to be stopped at any price, even if at times it meant the death of the heretic. ${ }^{3}$

During the Middle Ages, therefore, orthodoxy ${ }^{4}$ and religious liberty became incompatible. In that perfod of history, Christian unity was to be preserved not only through an emphasis on the

1see Pelikan, Cacholic Tradition, p. 71. Cf. Lecler and Valkhoff, Les premiers défenseurs, 1:14-19.

2Heribert Heinemann, "Heresy: Concept," $\underline{S M}$ (1969), 3:16.

${ }^{3}$ Lecler and Valkhoff, Les premiers défenseurs, 1:23-24.

"Meaning the "officially approved system" of belief. For the different meanings of the term orthodoxy, see above, "Introduction," pp. 5-8. 
institutional unity of the church--with, at its center, the Roman Pontiff--but also through a virtual hunt of heretics.

In this analysis of the composition of the orthodoxy-heresy structure, a new theological issue has come into focus, namely, the particular interpretation of the unity of the church's doctrine which ran parallel to the unification and centralization of its institutional life. This involves a shift of emphasis from the revelational criterion of Christian truth as expressed mainly in the apostolical and canonical norms to the ecclesiastical criterion as expressed in the traditionalistic and magisterial norms. It also means. consequenciy, that the ecclesiastical criterion of correct belief and teaching became strongly predominant over the canonical norm of orthodoxy. To be true, Christian truth was still considered to be founded on the Scriptures. However, it was stressed that only the Catholic Church's Magisterium could authoritatively and authentically interpret the Canon for the believers.

\section{The Emergence of the Issue of Infallibility \\ In addition to the emphasis on the unity of the chuich's} doctrine, another development took place in the Middle Ages--according to recent research, toward the 12 th or 13 th century ${ }^{1}$-.which was aimed at securing with absolute certitude the normative character of Roman Catholic magisteriai pronouncements. It was the emergence of the notion of the infallibility of the Magisterium.

\footnotetext{
I Brian Tierney, Orlgins of Papal Infallibility, 1150-1350: A Study on the Concepts of Infallibility. Sovereignty and Tradition in the Middle Ages (Leiden: Brill, 1972).
} 
As for the issue of papal infallibility, it was raised in the controversy over poverty (1279) between the Franciscans and the enemies of their order. 1 On that specific occasion, the idea of

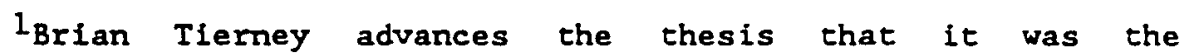
Franciscan controversy over poverty which occasivned the usage of the word "Infallibility" in connection with the papal magisterium (Tierney, Qrigins of Papal Infallibility, Pp. 93-130). There are at least two candidates for being first in proposing the idea of an infallible Pope. Tierney believes that the Franciscan priest Peter Olivi (Plerre Olieu, 1248-1298) was the first to attribute infallibility to papal pronouncements in 1280 (or by 1283, according to others) in his attempt to render irreversible Pope Nicholas III's approval of the Franciscan thesis that a stricter observance of poverty was a possible way to salvation. Nicholas III's approval was issued in the Constitution "Exilt qui seminat," on August 14. 1279. Olivi expounded his view on papal inerrancy in his Quaes:tiones XVII de perfectione evangelica (see Q. 14: "Quaestio an romano pontifici in fide et moribus sit ab omnibus catholicis tamquam regulae inerrabili obediendum?" published by $M$. Maccarone in RivStochIt 3 [i949]:309-343). On the life and work of Olivi, see Pierre Péano, "Olieu [Olivi, Pierre Jean]," DSp (1982), 11:751-62. For further information on Pope Nicholas III and his intervention in the Franciscan controversy, see $N$. A. Weber, "Nicholas III, CathEnc (1911), 11:56-57; and C. J. Lynch, "Franciscans," NGathenc (1967), $6: 41$. Other authors who likewise credit olfvi with being the first are Sullivan (Maristerium, $n$. 91); Hasler (How the Pope, p. 36); Anton Houtepen ("A Hundred Years after Vatican I: Some Light on the Concept of Infallibility," in Edward Schillebeeckx and Bas van Iersel, eds., Truth and Certainty, Soncillum [New York: Herder and Herder, 1973], p. 119); Hebblethwaite (New Inquisition?, P. 84); and Hans Küng ("A Short Balance-Sheet of the Debate on Infallibility," in E. Schillebeeckx and B. Jan Iersel, eds., Truch and Cercainty, $p$. 133). Others hold that it was Guido Terreni, a theologian of the 14th century, who first spoke expressly of the "infallible" truth of the teaching of the Roman Pontiff in matters of faith (see the Lutheran-Catholic "Common Statement on Teaching Authority and Infallibility in the Church," art. 21, in Paul C. Empie, T. A. Murphy, and J. A. Burgess, eds. Teaching Authority \& Infallibility in the Church: Lutherans and Catholics in Dialogue VI (Minneapol is: Augsburg Publishing House, 1980], p. 23). Terreni's statement was published by Bartholomaeus M. Xiberta, under the title Guidonis Terrent Quaestio de magisterio infallibili Romani pontfficis. opuscula et textus, Series scholastica et mystica, fasc. 2 (Münster: Aschendorff, 1926). Houtepen explains that Olivi's was an a posteriori qualification of a papal statement which had been accepted previously, whereas Terreni seems to have been the first who "gave it an a priori qualification" (Houtepen, "A Hundred Years after Vatican I," p. 119; cf. Sullivan, Magisterium, pp. 91-93). 
infallibility was almed both at marking off true doctrine from false with absolute certainty and, especially, at securing the "irreformability" of a pronouncement of Pope Nicholas III which had favored the position of the Franciscans. Interestingly enough, Pope John XXII condemed later the doctrine of papal infallibility as "the work of the devil." 1

It was, however, the Western Schism $(1378-1417)$ that crystalized the idea of an infallible ecclesiastical authority, ${ }^{2}$ though the latter was identified not with the pope but with the councils of the church. One of the most serious crises in the history of the Western church, the schism was a period during which the Roman Catholic Church counted three simultaneous popes. ${ }^{3}$ It formally ended when the Council of Constance (1414-1418) deposed all three and elected a new one. As a result, the Roman Catholic Church began to pursue the establishment of the idea of an infallible authority which could give some sense of security to its membership. To no one's surprise, many Christians at that time saw the council

IPope John XXII (1316-34) not only suppressed, in 1322, the rost important points of Nicholas III's Constitution "Exilt qui seminat," but also condemned the Franciscan doctrine of papal infallibility as the work of the devil in the bull "Quia quorumdam" (Nov. 10, 1324).

${ }^{2}$ In the Conciliarist controversy that took place in connection with the Western Schism and the Councils of Constance and of Basle, the word infallibility--rarely used in the patristic age and in the medieval theology--began to be used in "approximately the modern sense," observe Heinrich Fries and Johann Finsterhölzl ("Infallibility," SM [1969], 3:133). (1970) $6: 16-19$.

${ }^{3}$ See Johann Baptist Villiger, "Schism: Western Schism," SM 
as the supreme ecclesiastical authority ${ }^{1}$ and the court of appeal for settling religious controversies. In their attempt to heal the sense of uncertainty that the crisis had caused, men like Jean Gerson (1363-1429), the theologian of the Council of Constance, ${ }^{2}$ and Nicholas Cardinal of Cusa (1401-64) jegan to speak of the conciliar decisions as incapable of error. ${ }^{3}$

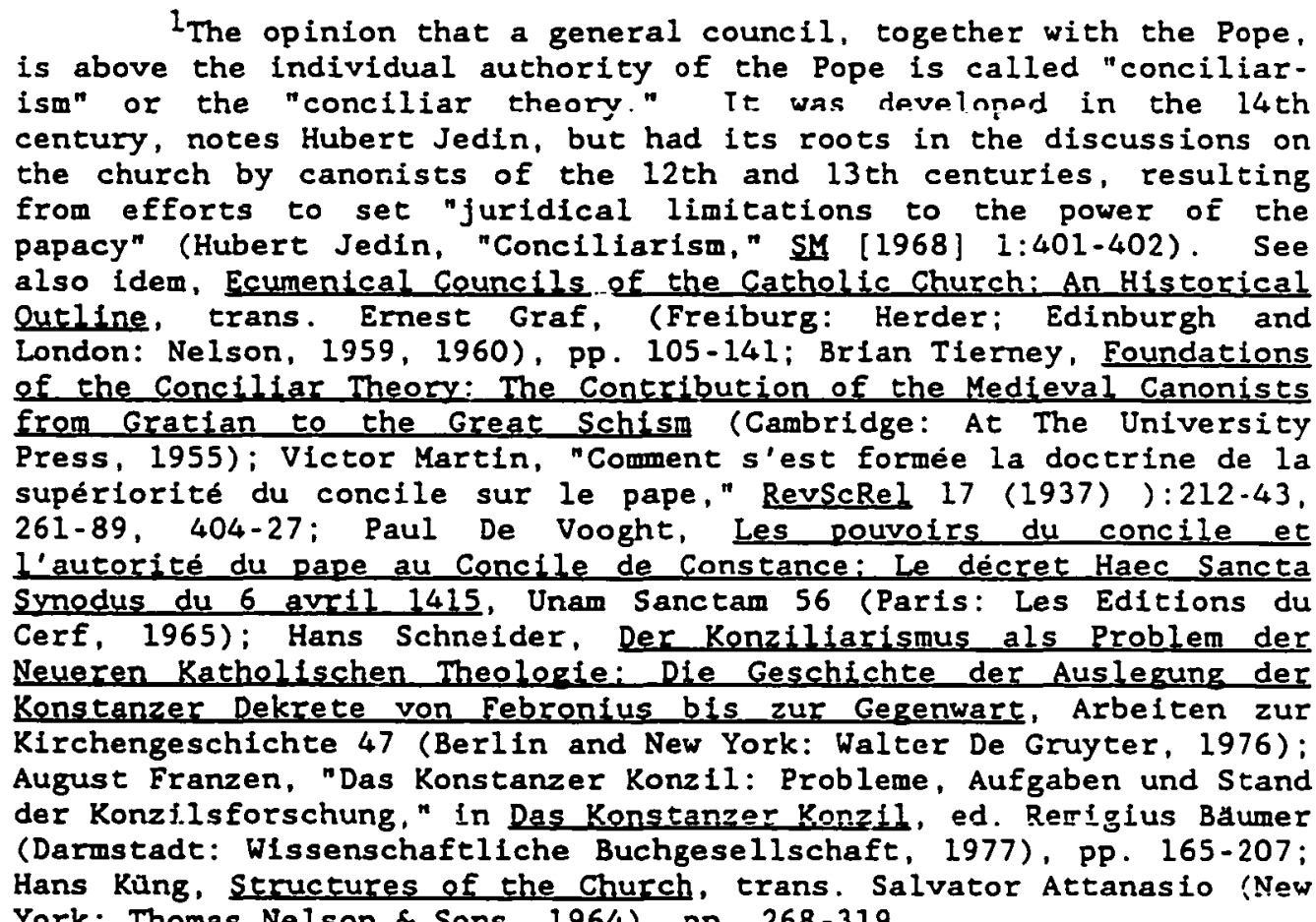
York: Thomas Nelson \& Sons, 1964), pp. 268-319.

2Remiglus Baumer, "Die E=forschung des Konstanzer Konzils," in Das Konstanzer Konzil, ed. R. Baumer, pp. 7.8. For basic information on the life and work of "Jean Charlier, dit Gerson du nom de son village natal," see Palémon Glorieux, "Gerson (Jean)," DSp (1965), 6:314-331.

${ }^{3}$ Nicholas of Cusa thought that the general council has "more authority and less iallioility than the Fupe" iquoted in De vooght, Les pouvoirs du concile, p. 166, n. 13). Hasler affirms that Nicholas of Cusa described the council as infallible (Hasler. How the Pope, p. 37). 
Toward the end of the Middle Ages the pronouncements of the Magisterium, either conciliar or papal, had clearly hecome the Roman Catholic principal norm of orthodoxy. Monolithic unity around this norm was stressed, and infallibility began to be attributed to it. To be true, the doctrine of the magisterial infallibility was elaborated in more detail after the Reformation and would play an increasingly important role in the Roman Catholic concept of orthodoxy starting from the 19 th century onward. At the end of the Middle Ages, however, it was in part the special charism of Infallibility which the Magisterium was believed to possess in order to maintain the church in the truth, and, as a consequence of this, the fact that orthodoxy was equated with the dogmatic system approved by the church's teaching authority, which causad any dissent to be regarded as a fall from the Christian truth and, therefore, as synonymous with the sin of heresy.

It should not escape our attention that the positive content of the term infallibility is simply "truth" or "truthfulness." In other words, it is assumed that if the church has a reliable teaching authority for its knowledge of truth, that authority must be Infallible. For this reason, a thorough study of the issue of infallibility should include at least some consideration of the notion of truth.

$1_{C f}$. H. Fries and $J$. Finsterhölzl, "Infallibility," p. 132. 
Orthodoxy and Heresy at the Time of the Protestant Reformation and After

The relation between orthodoxy and heresy which existed at the end of the Middle Ages was vigorously contested from the beginning of the 16th century by the Protestant Reformation. Though it can be rightly argued that the principal issue of the Reformation was the doctrine of redemption--in particular the sinner's justification, at the bottom of the controversy was the fundamental question of the nature of religious authority. 1 For the first time in the history of Christian thought, the authority of the Scriptures was extolled as preeminent over and against the authority of the living tradition of the church, 2 thus shifting the emphasis from the ecclesiastica]. Into the revelational criterion of orthodoxy.

In conformity with the analysis presented earlier in this chapter, one can speak of a confrontation between the authority of the revealed norms of Chrlstian doctrine and the authority of the ecclesiastical continuity of Christian doctrine. The doctrinal authority of the Canon (which contains the object of theological knowledge) was confronted with the teaching authority of the church (which is the agent transmitting and interpreting that knowledge).

\footnotetext{
${ }^{1}$ It must be noticed that the first principle identified in this research in relation with the definition of orthodoxy was involved here, namely, the principle of authority.

2 The confrontation may be regarded as one between theology and the institutional church. In our time the theologicalecclesiastical encounter tends to take the form of a tension between theologians and administrators in the church as, for instance, in the conflict between Hans kung and the Roman Curia.
} 
clearly, the two positions corresponded to a distinctly different emphasis put by each camp on one of the two traditional criteria of Christian truth. Sti11, both Catholics and Protestants remained convinced of the urgency of defending Christian truth from the attacks of error. Each simply saw the latter existing in the opposite party.

As a result of this controversy. from the time of the Protestant Reformation, it became increasingly difficult to speak simply of "crthodoxy." One must think now in terms of Roman Catholic and Protestant orthodoxies. Consequently, at that time the term "heretic" acquired a relative value. To Roman Catholics, the Reformers seemed to clearly fit the category of heretics since they adopted views contrary to the Roman Catholic norm of truth, i.e., the teachings of the ecclesiastical Magisterium. To the Reformers. on the contrary, these views could hardly be described as heretical since they understood them to be in accordance with what they regarded as the norm of truth, the Bible. From the Protestant perspective, those had fallen from the truth who rejected the primacy of Scripture. The Reformers' concern centered more around the original apostolic truth, which they perceived as being threatened by the policies and doctrines of the Roman Catholic Church rather than around the unity of the visible church.

The stress which Protestants put upon the normativity of the Canon involved the rising of two important theological issues.

In the first place, in affirming that the original gospel had been corrupted by the traditions of the post-apostolic church, 
Protestants were questioning the charismatic infallibility that Roman Catholics attributed to the Magisterium. In so doing the whole issue of doctrinal infallibility was indeed being raised. To question the charism of infallibility of the teaching authority of the church entails some reflection concerning the charism of infallibility of the apostles and their teaching.

The second issue is related to the tension between continuity and change in the church's theology. The basic theological problem here is how to harmonize the continuing, living, and shifting theological reflection ${ }^{1}$ of the community of believers ${ }^{2}$ with the written, fixed, and historically determined testimony of the Scriptures.

In my view these two theological issues pertain to the leading questions related to the orthodoxy-heresy antithesis which came into the foreground from the time of the Reformution to our own. As shall be shown, they are related to "modern" criteria and norms of truth which came into focus in the mentioned period. For this reason, as a necessary step in this historical-theoiogical outline, our attention concentrates mainly upon the issues of "the Infallibility of Christian doctrine" and "continuity-and-change in Christian theology," as well as on the new criteria and norms related to them.

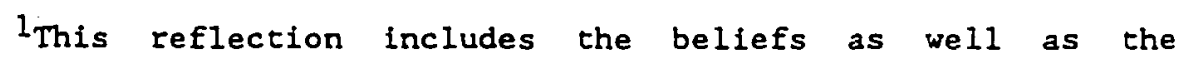
activities of worshipping, witnessing, proclamation and teaching.

2 In this living experience of the faith not only the Magisterium--nr any other teaching authority of the Christian churches-is involved.
} 
Infallibility and the Iruth of the Christian Doctrine

The concept of ecclesiastical infallibility which, as noted above, emerged within Roman Catholicism in the 13 th century was opposed by the Reformation. If Protestants recognized any infallibility in addition to God's, it was solely that of the canonical Scriptures.

In the Protestant-Catholic controversy, the infallibility of the Scriptures and that of the Magisterium were emphasized by each party, respectively, in an attempt to stress the truthfulness of their respective posftions. 1 The more Protestants contested the authority of the Roman Catholic Church and the Magisterium, the more Catholics stressed it. In their resistance to the reform movement, Catholic bishops invoked the doctrine of the infallibility of the church which in earlier times had offered Catholics a guarantee of doctrinal security. Yet, it is only after the pronouncements of the Council of Trent (1545-1563) that the doctrine of the infallibility

ITe infallibility of the Scriptures is one of the basic reachings in the confesstons of the churches of the Reformation in the 16th century. So, for instance, "The Formula of Concord," (A.D. 1576), article I (see PhIlip Schaff. The Creeds of Christendom, with a History and Critical Notes, [New York: Harper \& Brothers, 1877], 3:93-94); "The Belgic Confession," (A.D. 1561), article VII (see Ibid., 3:387-890); "The Second Helvetic Confession," (A.D. 1566). chap. I (see ibid., 3:237-38); "The Westminster Confession of Faith," (A.D. 1647), chap. I (see ibid., 3:600-606). In the Roman Catholic Church, the infallibility of the Scriptures was stressed explicitly in 19th-century magisterial statements (Pope Leo XIII's encyclical Providentissimus Deus, November 18, 1893; see Denz, 1951) in the context of the struggle against Modernism, even though explicit pronouncements zsojzing the more general concept of the divine authorship of the Bible appeared already in the 15th century (Council of Florence; see Denz, 706) as well as in the Council of Trent (third session, 1546; see Denz, 783). 
of the church became most strongly and universally taught in Roman Catholicism.

As for the Infallible authority of the pope-his ex cathedra decisions being irreformable ex sese and not in virtue of the church's subsequent confirmation ${ }^{1}$-this doctrine remained an "open question in some [Roman Catholic] quarters"2 till the 19 th century. It was erected during that century as a barrier against the dangers of secularization, rationalism, and Modernism ${ }^{3}$ and defined as a dogma in 1870 at the First Vatican Council. ${ }^{4}$ In its struggles against Modernism, the infallible Pope became as important for Roman Cacholic orthodoxy as the infallible Bible had been for Protestants in their encounter with Roman Catholicism. 5

The Catholic and the Protestant positions contrasted

From a Protestant perspective, the term infallibility itself, even though it $n$ is not a biblical one and does not play any great part in actual Reformation theology," 6 expresses the belief

1penz. 1839. Cf. Ratzinger, "Primacy, Episcopate, and Apostolic Succession," p. 39.

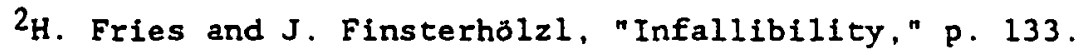

3On Modernism, see below, pp. 91-96; especially p. 91, n. 1.

${ }^{4}$ The infallibility of the pope is articulated in the First Vatican Council's Constitution Pastor aeternus (Session IV, of July 18, 1870; see Denz, 1832-1840).

5"Inerrancy" is often the term used for the infallible quality of the Scriptures.

${ }^{6}$ William C. G. Proctor, "Infallibility," BDT (1960), p. 284. See also George A. Lindbeck, in G. Baum, G. Lindbeck, R. McBrien, and H. J. McSorley, The Infallibility Debate, ed. John J. Kirvan 
that the church, according to Jesus' promise, will remain in the truth by the assistance of the Holy Spirit until the end of time (Matt 28:19-20; John 14:16-17; 16:13; 2 John 1-2) and will finally be victorious over evil (Matt 16:18). 1 Paul Althaus, for instance, holds that Jesus Christ's promise of the Spirit to the church means that. .

at no time will God let the church perish by itself, of its own sins and weakness, on the contrary, somewhere in the church the Spirit of God makes the truth and the life to break through anew for the whole church, somewhere he raises up prophets and reformers. This is the evangelical notion of the spiritual gufdance and the "infallibility" of the church. ${ }^{2}$

From the Roman Catholic perspective, infallibility means that the church is protected by the power of God's grace from "falling away from God's truth." 3 Though this definition strikes

(New York: Paulist Press, 1971), PP. 107-152; George Salmon, The Infallibility of the Church: Lectures Delivered in the Divinity School of the University of Dublin (London: John Murray, 1914); B. C. Butler, The Church and Infallibility (London and Sydrey: Sheed and Ward, 1969): Benjamin B. Warfield, The Inspiration and Authority of the Bible, ed. Samuel G. Craig, introduction by Cornelius Van Til (Philadelphia: Presbyterian and Reformed Publ. Co., 1948).

It must be noticed that so stated, this seems to be a doctrine of the church's indefectibility rather than infallibility.

2 Paul Althaus, Die christliche Wahrheit: Lehrbuch der Dogmatik, 8th ed. (Gütersloh: Gerd Mohn, 1969), p. 526, (my translation]. See also Emil Brunner. The Christian Doctrine of the Church. Faith, and the Consummation, Dogmatics, vol. III, trans. David Cairns and T. H. L. Tarker (Philadelphia: Westminster Press, 1962), Pp. 37-92; Karl Barth, Church Dogmatics, 2d. ed., ed. G. W. Bromiley and T. F. Torrance (Edinburgh: T.\& T. Clark, 1975), vol. I, part 2, pp. $688 \mathrm{ff}$.

${ }^{3}$ Karl Rahner and Herbert Vorgrimler, Dictionary of Theology, 2d. ed., trans. Richard Strachan, David Smith, Robert Nowell, and Sarah O'Brien Twohig (New York: Crossroad, 1981), p. 239. See also Dogmatic Constitution on the Church, art. 25, in Docs. of Vatican II, Pp. 48-49; and Luigi Ciappi, "Magisterium of the Church and Sacred Theology," trans. C. F. Lehner, in Vatican II: The Theolog- 
one as quite similar to the Protestant understanding, there remains an important difference. Roman Catholics see this infallibility as belonging to the pronouncements of the ecclesiastical Magisterium. Conversely, Protestant orthodoxy sees God's guarantee for the church to remain in the truth only as long as it adheres to the teaching of the Bible, the only infallible rule of faith and practice. 1

The Roman Catholic doctrine of the infallibility of the church's dogmas has the purpose of securing God's endorsement and, in consequence, the status of truth to the continuous interpretation and proclamation of the gospel by the church of all ages. Since tre Magisterium is viewed as protected by God's grace from error in proclaiming binding dogmas, Catholics dogmatically teach that all believers are "bound to shun any contrary doctrines," 2 otherwise they must be considered "heretics. " 3

In fact, the historlc tendency has been, when differing opinions arise in the church, to consider one of the contending parties to be Ifght and the other (or others) to be wrong. Believing that Jesus' promise of assisting the church to remain in the ersth must be fulfilled in that particular way, a difference has been made between the church and the heretics. To be true, this has

ical Dimension, ed. Anthony D. Lee, with introduction by Ferrer $E$. Smith ([U.S.A.]: The Thomist Press, 1963), pp. 196-210.

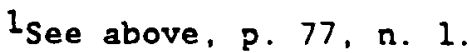

${ }^{2}$ CCL 1983, can. 750. CF. ibid., can. 752, 753, 754.

${ }^{3}$ CCL 1983 , can. 751 . 
81

been che acricude not merely of Roman Catholics. The Reformers likewise made a difference between the true and the false church. 1 As a result and especially during the 17 th century, ${ }^{2}$ in both the Reformed and Lutheran denominations as well as in Roman Catholicism there were no few examples of doctrinal intolerance and exclusivism.

Infallible teaching and changes in doctrine

The puzzling dilsmma, however, appears when a view regarded as heretical at one time is subsequently held as orthodox within the same tradition. 3 In the case of Roman Catholics, not surprisingly, the dogmatic status of the infallibility which they attribute to the church's Magisterium has at times created difficulties when changes have been introduced in its teaching. 4 In those cases, the solution

Isee, for instance, Calvin's Institutes of the Christian Religion 4.1.1-2;4.2.1-12 (LCC, 21:1011-14, 1041-1053).

2nIn Continental Europe the seventeenth century was a period of confessional orthodoxy. Lutheranism, as well as the Reformed tradition and the Roman Catholic Church, went through a process of systematization and clarification of the doctrinal positions that each of these bodies had taken during the previous century" (Justo L. Gonzalez, A History of Christian Thought, 3 vols. [Nashville and New York: Abingdon Press, 1975], 3:226).

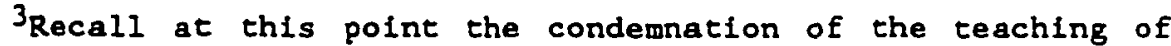
papal infallibility as "the work of the devil" by Pope John XXII (Bull "Quia quorumdam," November 10, 1324) and the posterior definition of papal infallibility as dogma of the Catholic Church by the First "atican Council (Constitution Pastor aeternus, July 18, 1870).

4Francis Simons, the Roman Catholic bishop of Indore. India, mentions several examples of relevant changes in Catholic teaching in his Infallibility and the Evidence (Springfield, IIlinois: Templegate, Publishers, 1968), pp. 113-18. Some of these are also scated in Küng's Infallible? An Inquiry (Garden City, New York: Doubleday \& Company, 1971), pp. 31-33, where the author refers to past positions of Roman Catholic doctrine as "errors." Karl Rahner 
has consisted either in formulating a reinterpretation that at times strikes many as a pronouncement contradicting the original one ${ }^{1}$ or, when such a reincerpretation proved impossible, in expressing the Magisterium's rejection of new evidence $s=$ the jensus fldelium, thus suggesting the leadership's unwillingness to repudiate an earlier pronouncement of the ecclesiastical Magisterium ${ }^{2}$ regaided as

concedes that "the Church has de facto very often made mistakes in the past." These, however, fall in the category of propositions of faith which are not "dogmas" properly so called but just "teachings" which, even though having "certain authority and binding force." have never been claimed by the church to be dogmatic, and therefore are, "In principle, reformable and possibly erroneous" (Rahner, Theolegical Investigations. Volume XIV: Ecclesiology, Questions in the Church. the Church in the World, trans. David Bourke (New York: Seabury Press, 1976], P. 60). Among the latter Rahner includes some "propositions of moral theology" such as Pope Paul VI's encyclical Humanae vitee (ibid., p. 83).

1While the Magisterium affirms that both say essentially the same thing, as, for instance, in the explanation of "outside the church there is no salvation" by Vatican II. Pope Boniface VIII formulated this view in his bull "Unam sanctam" (Nov. 18, 1302) in the fullowing terms: "With Faith urging us we are forced to believe and to hold the one, holy, Catholic Church and that, apostolic, and we firml; believe and simply confess this (Church) outside which there is no salvation nor remission of sin" (see Denz. 468). Vatican II's explanation appears to many as declaring that there is salvation outside the church: "Those who, through no fault of their own, do not know the Gospel of Christ or his Church, but who nevertheless seek God with a sincere heart, and, moved by grace, try in their actions to do his will as they know it through the dictates of their conscience--those too may achieve eternal salvation" (Dogmatic Constitution on the Church, art. 16. Cf. Küng, The Chufch, Pp. 403-411; also Simons, Infallibility, p. 115).

${ }^{2} \mathrm{~A}$ recent example is Pope Paul VI's encyclical Humanae vitae which, among other things, addresses the issue of birth control. In his general audience on $31 \mathrm{July}, 1968$, the Pope explained: "We have studied, read and discussed the matter as much as we could: we have also prayed a great deal. . . . We had to evaluate, bearing in mind both the duty and the freedom of our apostolic office, a doctrinal tradition that is not only centuries old but also recent, that of our three Immediate predecessors" (see "How the Pope Made up His Mind," HerdCor 5 [1968]:336; n. a.). 
binding. 1 The latter tends to cause major resistance on the part of some among the faithful.

Conversely, Protestant churches which recognize no infallible teaching authority apart from the Bible have been able. at times without major theological conflict, to correct some points in their teaching when a clearer understanding of some issues seemed to require it. This should not be understood to mean that members of Protestant denominations have not, at times, strongly resisted changes in the doctrine or discipline of their churches. ${ }^{2}$ when such a resistance occurs, the view held by the "conservatives" is, typically, that the changes are neither an improvement in the understanding nor a mere cultural adaptation of revealed truth, but simply and clearly a corruption of what they understand to be the truth of the Sciptures. This issue of change in Christian doctrine in the context of the discrimination between true and false belief

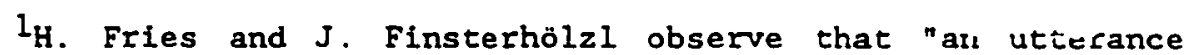
intended to be a dogmatic definition must be clearly recognizable as such." They criticize the tendency that exists in some quarters "to extend the notion and application of infallibility beyond its due Iimlts, especially with regard to the ordinary papal magisterium" ("Infallibility," p. 136).

${ }^{2}$ Change in doctrinal formulations or in church discipline and policies has never been without resistance. It seems that regarding the issue of continuity and change, human beings can be sorted under two main labels: conservative and progressive, though it should be recognized that they are rather relative descriptions. History shows that innovators in theology have been usually regarded by the established churches as disturbers of the peace and a danger for the progress of the church's mission. In such instances, issues raised by innovators are usually regarded as of minor importance, and an attempt is made to sheive the pioblem. At times this has been achieved by either persecuting the "heretics," or, in more recent times, by reducing them to silence by administrative means. 
and teaching deserves further attention and is addressed in the coming pages.

\section{The Issue of Continuity and change in Christian Doctrine}

It was mentioned above that from the end of the second century A.D. already such church fathers as Irenaeus and Tertullian affirmed that the true doctrine of the church always remains the same. Accordingly, the hallmark of orthodoxy, pointed out by Eusebius in the fourth century and by Vincent of Lerius in the fifth, was the continuity of the ecclesiastical tradition. Correct bellef and teaching was that which one could demonstrate to be the same as the apostolic teaching existent before the rise of heresy.

By the time of the sixteenth-century Reformation, however, the Protestant allegation that the church had departed widely from the norm of the original apostolic tradition as recorded in the NT Canon became one of the central theological issues. The importance of this matter cannot be stressed enough. Tt is Father John $C$. Murray's thesis that the parting of the ways between Roman Catholicism and Protestantism took place precisely on the issue of the development of dogma. ${ }^{2}$ There is no question, for him, as to

1John C. Murray, The Problem of God: Yesterday and Today (New Haven and London: Yale University Press, 1964), which contains Murray's address at the inaugural series of St. Thomas More Lectures at Yale University, delivered in 1962.

${ }^{2}$ obviously, the issue of continuity and change in Christian theology is closely related to that of the "development of dogma," which is understood in at least two different ways among Christians, namely, in the Modernist and in the traditional Roman Catholic senses (see below, pp. 87-88,91-95). William Reiser labels them the "historical-critical approach" and the "organic view," 
whether or not there has been change in Christian tradition. The question is, rather,

What is legitimase development, what is organic growth in the understanding of the original deposit of faith, what is warranted extension of the primitive discipline of the Church, and what, on the other hand, is accretion, additive increment, adulteration of the deposit, distortion of the Christian discipline? ${ }^{+}$

Since it seems difficult to deny that development in the sense of change ${ }^{2}$ has occurred both in Catholicism and Protestantism, ${ }^{3}$ one theological dilemma exists precisely in distinguishing between legitimate development and adulteration of the original Eaith. This is, to be sure, a problem of discriminating between true and false (orthodox and heretic) Christian doctrine for which the basic question is, What are the criteria and norms by which to judge between true growth and rank excrescence? ${ }^{4}$

respectively (see William Edward Reiser, "What Calls Forth Heresy?: An Essay on the Development of Dogma Within a Heideggerfan Context" [Ph.D. dissertation, Vanderbilt University, 1977], Pp. 17-71).

$1_{\text {Murray, The Problem of God, p. } 53 .}$

2One should keep in mind that the concept of "development" does not necessarily imply that improvement is the automatic occurrence in the history of Christian theology. It rather means that change has taken place, efther because of the promised illumination of the Holy Spirit (John $14: 26 ; 16: 12-13$ )--in this case change would mean growth in truth--or because of the ever-changing historicel sanditiens and philosophical trends in which the church is immersed. In the latter instance, change is not necessarily guaranteed to be in truth.

3It must be recognized that the gospel was expounded neither in the fourth and fifth centuries--for instance, in the formulae of the Nicaean and Chalcedonian creeds--nor in 16th century's Roman Catholicism and Protestantism exactly as it was in the New Testament writings. Change indeed has taken place in the formulation of the church's teaching.

\footnotetext{
${ }^{4} \mathrm{Cf}$. Murray, The Problem of God, P. 53.
} 
The problem of defining the criteria for discriminating between legitimate and unfounded development has to do with the question of how we can reconcile our continually changing understanding of the gospel with the essentially "crce-and-for-all" nature of God's revelation enclosed in the gospei. 1 The tension between the revealed norms of Christian doctrine (the apostolic teachings as recorded in the NT Canon) and the ecclesiastical norms of orthodoxy (the church's traditions and magisterial pronouncements) is a specific manifestation of this problem.

The Protestant allegation that the Roman Catholic Church had departed from the original norms of Christian truth, and, on the other hand, the Roman Catholic insistence on the authority of the Magisterium, brought the tension existing between the written norm and the living tradition explicitly and vividly into focus. Further, in the Protestant-Catholic confrontation that tension was brought to a deadlock. In epistemological terms, the impasse Involved the interpretation of the object of theological knowledge (originally recorded in the Canon) by the agent (i.e., the teaching authority of the church), a problem which was given not only in the Protestant-Catholic confrontation, but within both the Roman Catholic and the Protestant traditions as we11.2 All in all.

$I_{\text {This is perhaps "the crucial purely theological issue for }}$ Catholics today" (see the unsigned article, "Dogma, Freedom, Change and Continufty," HerdCor 5 [1968]:265). This observation is not less true of Protestants.

2 It may suffice to recall at this junction that even for Luther, the defender of the sola scriptura principle, there was a canon within the Canon. For that very reason he questioned the authority of the epistle of James. 
87

Protestants tended to stress the infallibility of the original deposit alone, while Roman Catholics added the infallibility of the agent interpreting it. Though both parties agreed as to the infallible authority of the canonical Scriptures, they differed in their appreciation of the infallibility of the teaching authority of the church.

The problem of orthodoxy and heresy thus began to be opened to the interpretative level in an increasingly conscious manner. As in all epistemological structure, in the composition of the orthodoxy-heresy antithesis three basic elements or factors were present from the beginning: (1) The object of theological knowledge, (2) the agent who knows, namely, the church and its teaching authority, and (3) the interpretative process itself involving both a theory of being and a specific theory of knowledge. In the history of the church and at the conscious level, the emphasis had first been put on the object and subsequently on the agent of theological knowledge. In the post-Reformation period, however, the third epistemological element began to be taken explicitly into consideration. It was coming distinctly to the Christians' consciousness, for the first time, that there was need for a hermeneutical criterion able to address the problem of truth without restricting its solution to the factors of the original deposit (the object) and the teaching autiority of the church (the agent). The important question of the hermeneutical criterion of truth is addressed later in this chapter ${ }^{1}$ and throughout the dissertation.

\footnotetext{
Isee below, pp. $96 \mathrm{ff}$.
} 
Returning to the issue of the development of dogma, at least three major interpretations may be distinguished. Two of them correspond to what we might label the traditional Protestant and Roman Catholic positions. The third type of interpretation appeared in the last two centuries among liberal protestants and "modernistic" Catholics, whose positions can be put under the common denomination of Modernism. 1

Traditional Protestantism views the doctrinal changes in the Roman Catholic tradition as a corruption of the gospel. Conversely, traditional Catholicism came to regard these changes as organic growth of the Christian truth. In general, Roman Catholics have tended to stress the essential immutability of their doctrine whose correct adaptation to contemporary situations is said to be guaranteed by the charism which the Holy Spirit grants to the church's Magisterium. 2 The historic Protestant position, on the contrary, is that the norm by which all new theological formulations are to be judged is expressed by the principle of sola scriptura. ${ }^{3}$

The issue of development was systematically addressed from a Roman Catholic perspective by John Henry Cardinal Newman in the

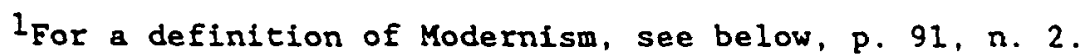

2-Ine Catholic version of the development of dogma underlines the authority of the church's living tradition.

${ }^{3}$ Neither position as such, however, solves all the problems. Equating the work of the Holy Spirit with all church pronouncements, as some Catholics contend, renders difficult the recognition by the church of its own mistakes. On the other hand. Evangelical Protestants, all claiming to follow the sola Scriptura principle, arrive at contradictory conclusions in several doctrines (see Robert $K$. Johnston, Evangelicals at an Impasse: Biblical Authority in Practice [Atlanta: John Knox Press, 1979], Pp. vii-viii). 
nineteenth century. 1 His seven tests of authentic doctrinal development ${ }^{2}$ are said to be the first contribution to the Catholic theory of development of doctrine, not counting "pale anticipations in Tertullian's late Montanist works."3 Realizing that every form

1J. H. Newman, An Essay on the Development of Christian Doctrine (Westminster, Maryland: Christian Classics, 1968. Reprint of the $1845 \mathrm{ed.}$. . Even though others before Newman proposed the organic model of development of dogma (like the Catholic scholars of Tübingen, J. S. von Drey and J. G. Möhler) Newman's writings proved to be more influential. See John Adam Möhler, Symbolism; Or Exposition of the Doctrinal Differences between Catholics and Protestants, as Evidenced by Their symbolical Writings, trans. James Burton Robertson (New York: Edward Dunigan, 1844). On von Drey's work, see Karl Rahner and Karl Lehwann, in Johannes Feiner, ed., Mysterium salutis: Grundriss Heilreschichtlicher Dogmatik, 5 vols. (Einsiedeln: Benziger Verlag, 1965), 1:747. See also Reiser, "What Calls Forth Heresy?," pp. $21 f f$.

In Newman, An Essay, pp. 171-206ff. In sketch, the seven tests of genuine doctrinal development are: (1) the "preservation of type," i.e., the preservation of the essence which characterizes Christian teaching, (2) the continuity of principles: "doctrines grow and are enlarged, principles are permanent" (see ibid., $p$. 178), (3) the "unitive power" of faithful developments: they tend to the assimilation of elements rather than to their disgregation, (4) the "logical sequence" of a doctrine regarding its original form. (5) the "anticlpation of its future": a legitimate ultimate development must be "anticlpated" at an early perlod in the history of the idea to which it belongs, (6) the "conservative action" upon its past: a true development -ends to be conservative of what has gone before it, and (7) the "chronic vigour" or permanence of the legitimate development. Conversely, Newman thinks "the course of heresies is always short" (ibid., p. 204).

${ }^{3}$ So Anselm Atkins, "Religious Assertions and Doctrinal Development," IS 27 (1966):539. Jaroslav Pelikan suggests that this judgment is exaggerated. He holds that the Commonitorium of vincent of Lérins was more than a "pale anticipation," not to mention some comments on doctrinal development made by Gregory of Nazianzus in the fourth century, Thomas Aquinas in the $13 \mathrm{th}$, and several others before 1845 (cf. above, p. 89, n. 1) (Pelikan, Development of Christian Doctrine: Some Historical Prolegomena (New Haven and London: Yale University Press, 1969], p 2). Pelikan acknowledges, however, that his book is in a sense the result of the thoughtprovoking nature of Newman's An Essay, which he regards as "the almost inevitable starting point for an investigation of development of doctrine" (ibid., p. 3). 
of Christianity at that time was not identical with the religion of the apostles, Newman wrote on the difficulty of applying the dictum of Vincent of Lérins ${ }^{1}$ to that specific situation. His theory of development of doctrine sought to explain how the teachings of the Roman Catholic Church of his days could be seen as a logical. historical unfolding of the apostolic tradition. The current teachings of the church were considered as a legitimate growth sanctioned by the authority of Its Magisterium. Although there have been variations from Newman's views through the years, all proponents of the traditional Catholic "organic" model 2 agree on the basic idea that the living tradition has grown without losing its identity. ${ }^{3}$ Clinging to the principle that its doctrine is semper eadem. ${ }^{4}$ Roman Catholicism holds that if there is any historical

I"True doctrine is believed everywhere, always, by all" (Commonitorium primum 2 [PL, 50:640]).

${ }^{2}$ For instance, Karl Rahner, in Karl Rahner and Karl Lehmann, Keryoma and Dogma, trans. William Glen-Doepel (New York: Herder and Herder, 1969): Avery Dulles, The Survival of Dogma (New York: Doubleday \& Co., 1971): Bernard J. F. Lonergan, Method in Theology (New York: Seabury Press, 1972); and Jan Walgrave, Unfolding Revelation (Philadelphia: Westminster Press, 1972).

${ }^{3}$ For an illuminating treatment of this matter, see $W$. E. Reiser, "What Calls Forth Heresy?," pp. 17-54.

${ }^{4}$ As already mentioned (see above, p. 54, especially n. 4), very early in its history the church claimed that its doctrine had remained the same from the time of the apostles. The classical dictum of Vincent of Lérins ("true doctrine is believed everywhere, always, by all") postulated in essence this idea in a rather elaborated way as early as the fifth century. Towards the end of the 17th century Jacques-Benigne Bossuet wrote his classic, Histoire des variations des églises protestantes (Paris: 1688) whose thesis was that the doctrine of the true church is always the same, whereas Protestants have drawn up their confessions of faith with "many varfations" and "inconstancy" (see Jacques-Bènigne Bossuet, History of the Variations of the Protestant Churches [New York: D. \& J. 
development in the teaching of the church, it is an organic development, namely, the logical unfolding of what was already inherent in the church's depositum fider. ${ }^{1}$

Though their view of the nature of the Scriptures is quite different from that of the Reformers of the sixteenth century, the "liberal" theologians of the nineteenth century and the so-called "Modernists"? of the early twentieth may be considered as heirs of the Reformation to the extent that their alleged concern was the

Sadlier, 1850], p: 3).

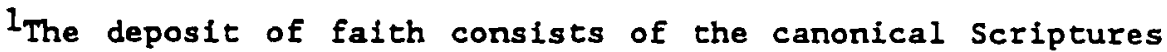
and sacred tradition, teaches the Second Vatican Council in its Constitution on Divine Revelation, art. 10 (see Docs, of Vatican II, p. 117). This treasure, however, is capable of further development, i.e., of an "organic growth" in the understanding of the gospel (see Const. on Divine Revelation, art. 8 (Docs, of Vatican II, P. 116]).

2 In the strict theological sense. "Modernism" designates the tendency rather than a set of definite doctrines which caused the crisis in the doctrine and discipline of the Roman Catholic Church at the end of the 19 th and the beginning of the 20th century (see Roger Aubert, "Modernism," SH [1969], 4:99). In his volume Justiffcation, Hans Küng contrasts the Roman Catholic understanding of the development of dogma "In the sense of explication" of the truths of faith, with development of dogma "in the sense of Modernism" (Küng. Justification: The Doctrine of Karl Barth and a Catholic Reflection, trans. Thomas Collins, Edmund E. Tolk, and David Granskou (Philadelphia: Westminster Press, 1981], p. 101). Though the term is ambiguous and is used mostly in Roman Catholic circles to designate the "fifth column within the fortress of the Catholic Church" (T. Mark Schoof, O.P., A Survey of Catholic Theology: 1800-1970, trans. N. D. Smith [Glen Rock, New Jersey: Paulist Newman Press, 1970], p. 45), it might be used to designate the mentality and concerns of modern Christians in general, as some conservative Protestants did in referring to both the anti-Christian tendencies of the modern world and the radicalism of Protestant liberal theology (Aubert, "Modernism," p.99). For a detailed study of the sc-called "modernist controversy" in Roman Catholicism at the beginning of the 20th century, see Thomas Michael Loome, Liberal Catholicism. Reform Cathollcism. Modernism: A Contribution to a New Orientation in Modernist Research, Tübinger Theologische Studien, Band 14 (Mainz: Matthias-Grünewald-Verlag, 1979). 
purity of the gospel. 1 Some of them interpreted the changes that had occurred in the history of Christian thought as a corruption of the original gospel transformed into a dogmatic Christianity. In what wight be considered one of the more enduring nineteenth-century models of "the falling away of the church," Harnack regarded the "hellenization" of the orlginal Christian message ${ }^{2}$ as the substitution of the true by a false form of Christianity.

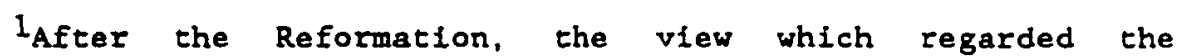
"development of dogma" as a deviation from the norm of the original gospel was first raised by theologians of the liberal Protestant camp. Adolf von Harnack, for instance, saw in the development of dogma nothing but a process of decay, a corruption of the undogmatic faith that he belfeved was a feature of the primitive church. It was the influence of Greek thought over the Christian message, thought Harnack, that caused the latter's corruption. He regarded dogma, both in its conception and development, as "a work of the Greek spirit on the soil of the Gospel" (Harnack, History of Dogma, 1:1-23, especially p. 17. CF. Idem, what Is Christianity? Sixteen Lectures delivered in the University of Berlin during the winterTerm 1899-1900, trans. Thomas Bailey Saunders [London: Willlams and Norgate, 1901], especially pp. 146-51, 190-209). See also Pelskan, Development of Christian Doctrine, Pp. 25ff.; and Bernhard Lohse, $A$ Short History of Christian Doctrine, trans. F. Ernest stoeffler (Philadelphia: Fortress Press, 1978), pp. 1-4. For a brief treatment of Harnack's theory of the "hellenization" of Christian theology, see Wilken, The Myth, PP. 140-46; see also G. Wayne Glick, The Realiry of Christianicy: A Scudy of Adolf von Harnack as Historian and Theologian, Makers of Modern Theology series, ed. Jaroslav Pellkan (New York: Harper \& Row, 1967), especially PP. 150152 .

${ }^{2}$ Harnack affirms that "As Catholicism, from every point of view, is the result of the blending of Christianity with the ideas of antiquity, so the Catholic dogmatics, as it was developed after the second or third century on the basis of the Logos doctrine, is Christianity conceived and formulated from the standpoint of the Greek philosophy of religion" (Harnack, History of Dogma, 2:13-14). Auguste Sabatier regarded the notion of dogma or "divine doctrine" as springing from a combination of the "Greek rationalism and Hebrew supernaturalism" which were already operative during Paul's lifetime (A. Sabatier, Outlines of a Philosophy of Religion, p. 44). If these observations are correct, it means that early in the history of Christian theology the philosophical trends of the time had influenced theological reasoning. 
A common characteristic of liberal and Modernist theologians of the nineteenth and early twentieth centuries is that, within the context of a new "historical consciousness,"l they came to realize that many of the doctrines and dogmas ${ }^{2}$ which the churches presented

'see Albert C. Outler, "The Idea of 'Development' in the History of Christian Dectrine: A Comment," in Schools of Thought in the Christian Tradition, ed. Patrick Henry (Philadelphia: Fortress Press, 1984), pp. 9-10.

2 Some Protestants claim that their churches have produced no "dogmas," thus implying that the latter, over against "doctrines:" are by definition infallible and irreformable formulations of the Christian faith (see Hendrikus Berkhof, Introduction to the Study of Dopmatics [Grand Rapids, Michigan: Eerdmans, 1985], p. 5; cf. Bernhard Lohse, A Shert History, Pp. 7-8). At this point a difference between doctrine and dogma may prove helpful. "Doctrine" (from the Latin doctrina - teaching) designates in a general way the articulate form of a church's belief and proclamation. Jaroslav Pelikan describes Christian doctrine as "what the church of Jesus Christ belleves, teaches, and confesses on the basis of the word of God" (Pelikan, Catholic Tradition, pp. 1, 3). He holds that doctrine includes what is "believed" (devotion, spirituality, worship), what is "taught" (Instruction, proclamation, and churchly theology), and what is "confessed" against false teaching from within and against attacks from without (creed and dogma). Pelikan distinguishes between doctrine and dogma. The latter, in his view a more restricted term than doctrine, is a normative statement of Christian belfef "adopted by various ecclesiastical authorities and enforced as the official teaching of the church" (ibid., PP. 3-4).

From a Roman Catholic perspective "dogma," in the sense in which the term is used nowadays in the church (i.e. since Trent and the First Vatican (ouncil), is a proposition which is the object of fides divina ef catholica, one which the church explicitly propounds as revealed by God in such a way that its denial is condemned by the church as heresy and anathematized (see Karl Rahner, "Dogma: Theological Meaning," SM [1968], 2:96. See also Denz. 1792; and CCL, 1983, can. 750; cf. CCL, 1963, can. 1323, \#1 and \#2. For the definition of heresy and its condemnation, see CCL,1983, can. 751, 752, and 1364, \#1; cf. CCL, 1963, can. 1325, \#2, and 2314, \#1). Rahner holds that "the decisive characteristics of dogma" are divine origin, truth, the obligation to believe it, and immutability, among others (ibid.). Lohse affirms that for Protestantism, on the contrary, "the conception of dogmas as infallible propositions of faith has never had validity" (Lohse, A Short History, p. 8). Hence in Protestant quarters "dogma" is generally either deprived of any connotation of infallibility or replaced by the term "doctrine". which better conveys the idea of openness to correction. 
as eternai truchs handed down unchanged from generation tó generation since the apostolic age had often had their origin in later historical circumstances. 1

This approach had its roots in the "Dogmengeschichte" school, a theological discipline which flourished in the eighteenth century as a reconception of the history of Christianity. 2 Using historical-critical methods, its essential aim was to provide historical justification for superseding the patristic and medieval dogmas by reformulations based on "contemporary understandings" of Scripture and Christian experience. 3

As could be expected, both traditional Roman Catholicism ard conservative Protestantism have reacted negatively to the idea of development of dogma in the Modernist sense. ${ }^{4}$ For conservative

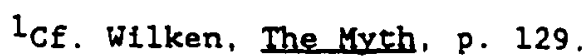

2 There are many candidats sor the title of "founder" of the "history of dogma" school, among them Semler, Walch, Münter, Münscher, Lange (see Outler, "The Idea of 'Development'," $p .10$ ). Wilken polnts out that Johann Semler (1725-1791), sometimes called the "father of Dogmengeschtchte," was "the most brill lant representative of this new historical consciousness" (Wilken. The Myth, pp. $129-30$ ).

${ }^{3}$ See Outler, "The Idea of 'Development'." p. 10.

${ }^{4}$ See, for instance, the condemnation of "modernity" and its works in Pope Pius IX's "Syllabus" or "Collection of Modern Errors" (1864), in Denz. 1705. See also Vatican I's Dogmatic Constitution on the Catholfic Faith (1870), In Denz. 1800; and Pius X's "The Errors of Modernists, on the Church, Revelation, Christ, the Sacraments" (1907), Denz. 2057-2065a; also his Encyclical "Pascendi dominici gregis" (1907), Denz. 2080; and his "Oath Against the Errors of Modernism" (1910), Denz. 2145; as well as Pius XII's Encyclical "Humani generis" (1950), Denz. 2309-2311. According to Leslie Dewart, Roman Catholicism made the conscious decision since the end of the eighteenth century "to avoid developing dogma so far as possible," a decision which, in his view, revealed a theoretically mistaken notion of the relation of dogma to culcure (Leslie 
Protestants the liberal-Modernist interpretation constitutes a threat to their understanding of the authority of the Scriptures, whereas for Roman Catholics the Modernist approach ultimately implies a threat to the foundations of the teaching authority of the church. 1 Doctrinal developments cannot, in principle, contradict former pronouncements of the church's Magisterium since every new dogma must have been potentially contained in the deposit of faith. from the beginning. 2

The Modernist interpretation of the development of Christian doctrines corstitutes an evidence of the epistemological shift which underlined the hermeneutical factor of theological knowledge ${ }^{3}$ as the locus where the antithesis of doctrinal truth and error was being addressed. As mentioned earlier, the hermeneutical element has come increasingly into focus during the last two hundred years or so of

Dewart, The Future of Belief: Theism in a World Come of Age [New York: Herder and Herder, 1966], p. 108). Pelikan points out the irony in this particular Catholic position, since 1854, 1870, and 1950 "are the specific points at which the develnpment of dogma "sas not only acknowledged de facto but promulgated de jure" (Pelikan, Development, p. 29). For an introduction to a contemporary statement of the issue, see Maurizio FIick, "Il problema dello sviluppo del dogma nella teologia contemporanea," Greg 33 (1952):5-23.

${ }^{1}$ Cf. Catherine Mowry LaCugna, The Theological Methodology of Hans Küng (Chico, Californla: Scholars Press, 1982), p. 103. Hereafter referred to as LaCugna, Methodology of Küng.

${ }^{2}$ Cándido Pozo, "Dogma--Development," SM (1968), 2:100; cf. Lohse, A Short History, p. 7. "Since the closing of revelation does not mean that providence ceases to watch over the further progress of Church history and the history of dogmas, infallibility may be regarded as a corollary to the development of doctrine," write Fries and Finsterhölzl ("Infallibility," p. 132).

${ }^{3}$ On the three basic elements of all structure of knowledge, see above, p. 87 . 
church history. Until the time of the Protestant Reformation the controversies about doctrine had been mostly restricted to the factors of the object and agent of theological knowledge-.i.e., the orfginal deposit of faith and the ecclestastical Magisterium, respectively. Now, even though the basic elements of theological knowledge remained the same, 1 the orthodoxy-heresy ist.1e was being moved from the Scriptures-Magisterium controversy to the hermeneuticai level. Moreover, the interpretation of the way in which the agent and the object of theological knowledge interact was changing radically. In the liberal-Modernist theories of the development of dogma the new world-view which had begun to prevail in the West from the eighteentt century onward may be seen at work. To consider this change in the world-picture I now turn.

\section{Orthodoxy-Heresy and the New Hermeneutical Criterion}

It is widely accepted today that theologians in the patristic and medieval church looked upon the Hellenistic worldview, shaped principally by Platonic and Aristotelian philosophy, 2

$1_{\text {That }}$ is to say, the object of theological knowledge (contained in the Canon) and the agent (the church, either Catholic or Protestant, and its teaching authority) were still there, in the same way as the hermeneutical dimension was present in the theological reflection of earlier centuries--though mostly unconsciously.

${ }^{2}$ starting with the pioneer work of Parmenides (born about 510 B.C.) and following with Plato's philosophy, "being" and "truth" were thought of as belonging to a metaphysical, suprasensible, and timeless realm. Truth could not possibly be found in our physical. sensible, and time-bound world. In Plato's view, the structure of realicy was conceived as divided in two great regions or realms, namely, the world of senses or things (the realm of mere appearances accessible to the natural senses), and the world of the mind (the 
as a divinely ordained preparation for the reception of the gospel. In the model provided by the Hellenistic conception of reality of their time, the early fathers found support for the belief in the existence of one absolute, transcendent, unchangeable, unmovable, and timeless God' whose Being was the ground for the existence of one absolute, transcendent, unchangeable, unmovable, and timeless truth. They came to think of God and truth as unchangeable and static, essentially belonging to the supernatural, suprahistorical, and timeless world which constituted the superstructure of our visible world. This cosmological and theological view prevalled in the Platonic-Augustinian theology and was still preserved in the Arlstotelian-Thomistic theology of the Middle Ages.

From a modern perspective, then, the antithesis of orthodoxy-heresy in the first centuries is generally analyzed as follows: Since the early fathers thought of "truth" in general as essentially abiding in the realm of a transcendent, immutable reality, they could not conceive Christian truth otherwise but as being one and only one. Thus, and over against the diversity existing in the afostolis days, one theological understanding of Christian belief alone came to be tolerated as "true doctrine" by

transcendent realm of Ideas were reality exists). This view prevalled in the Neo-Platonism of the second century A.D.

In the patristic age, the understanding of God's nature was influenced by Greek metaphysics. The Platonic cosmological separation of reality in two tiers, as well as the Aristotelian concept of God as the timeless, unmoved Mover, affected the way of understanding the relationship between God and our world, as well as the self-disclosure of God in relation to the cognitive activity of human reason. 
the church of the patristic age and onward. In addition, it seems that the early fathers could hardly distinguish between truth and human perception of truth. For them, the mind functioned as a tabula rasa that received impressions from the exterior world. Since it was considered at that time that there was a direct relationship between what the mind of the subject knows and objective reality, it was thought that the objects alone colid define the characteristics of knowledge. 1 Therefore, the fathers tended to regard all variatiors from their own doctrinal views not as possible different perceptions of the same Christian message but simply as belief in the "wrong thing." They also affirmed that all views which differed from their own had appeared late in the history of the church and should be regarded as erroneous innovations or heresies.

It must be observed that in some instances, however, the view which prevalled and banned all others was not in harmony with the testimony of the $\mathrm{I}$ C-sion. This was, In part, the result of the fathers' attempt at making the Christian religion reasonable and relevant to the modern-minded, secular circles of their days. ${ }^{2}$ At

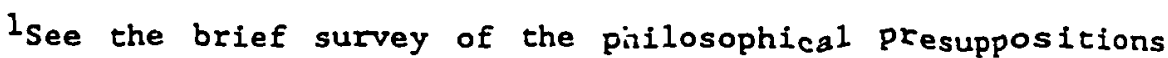
of ancient Christian theology in E. Edward Zinke, "A Conservative Approach to Theology:" Ministry, October 1977, PP. 24A-24P.

${ }^{2}$ The apologists generally held that some parts of the Bible could not be taken literally, namely, those which did not fit in the world-view of their days, or which were not acceptable in some philosophically sophisticated circles. So Justin wrote that "The ineffable Facher and Lord of all neither has come to any place, nor walks, nor sleeps, nor rises up, but remains in His own place, wherever that is,. . . having neither eyes nor ears, but being of indescribable might; and $\mathrm{He}$ is not moved or confined to a spot in the world, for He existed before the world was made. How, then, 
the same time, in their struggle against what they saw as false teaching, early Catholics' final norm was not the authority of the canonical writings of the NT accepted in common with other Christians, 1 but the pronouncements of the bishops who held an office by apostolic succession.

The described interpretation of the developments in ancient Christian theology corresponds to a motif which is familiar to systematic theologians since the last century, namely, the "hellenization of Christianity." The latter implies that during the first generations of church history there was a movement on the part of Christianity from a Jewish to a Hellenistic cultural and ideological context. ${ }^{2}$

There are different approaches to the issue of the

could He talk with any one, or be seen by any one, or appear on the smallest portion of the earth . . .?" (Justin Martyr Dialoque with Tryoho 127 (ANF, 1:263]). Similarly, Origen of Alexandria commenting on the first chapters of Genesis asked: "What man of intelligence will believe that the first and the second and the third day, and the evening and the morning existed without the sun and moon and stars? . . . And who is so silly as to believe that

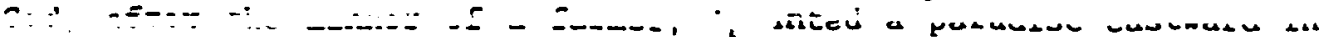
Eden.' . . . And when God is said to 'walk in the paradise in the cool of the day'. . . I do not think anyone will doubt that these are figurative expressions which indicate certain mysteries through a semblance of history and not through actual events" (Origen on First Principles 4.3.1. See G. W. Butterworth, ed. and trans.. Origen "On First Principles", introduction by Henri De Lubac [Gloucester, Massachusetts: Peter Smith, 1973], p. 288, Greek text).

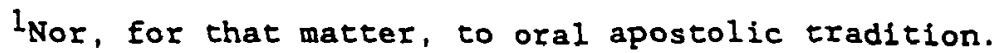

${ }^{2}$ Commenting on this movement George A. Lindbeck notes that it took centuries for the fundamental meaning of the faith to be "coherently and comprehensively restated in Greek terms, and the end product of the process was in some respects immensely different from the original." Withcut being specifically denied, adds he, the Jewishness of the faith "had largely vanished" (Lindbeck, in The Infallibility Debate, p. 109). 
hellenization of Christianity. The view of Harnack, who contested the legitimacy of the development of Christlan dogma on the grounds of its hellenization of the primitive message, 1 is sourtered by those who hold that it is misleading to speak of the hellenization of ancient Christian theology ${ }^{2}$ and suggest that it is more accurate to think of dogma in terms of a "dehellenization" of the theology that had preceded 1 t. $^{3}$ In still another position, some recognize that there has been a hellenization of theology but propose that Harnack's understanding of it as a corruption of the gospel be replaced by a different interpretation, namely, that hellenization is the adoption of a hellenic cultural form "without the implication that it is the substitution of the true by a false form of Christianity." 4

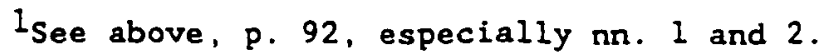

2Jaroslav Pelikan, for instance, judges Harnack's riew of the hellenization of Christian doctrine as "a distortion" (Pelikan, Catholic Iradition, p. 55). He prefers Werner Elert's view that by its dogmas the church rather threw up a wall against an alien metaphysics (Werner Elert, Der Ausgane der alckirchlichen Christologie: Eine Untersuchung über Theodor van pharan und seine zeit als Einführung in die alte Dogmengeschichte, ed. Wilhelm Maurer and Elisabeth Bergstrasser [Berlin, 1957], p. 14).

${ }^{3}$ For this particular matter, see Pelikan, Catholic Iradition, P. 55.

${ }^{4}$ So Leslie Dewart, The Future of Belief, p. 133. Dewart holds that the hellenization of Christianity was rather the imperceptible transformation of an earlier cuitural form into a later one, "It being assumed that the truth of Christianity depended on neither form as such." For reactions of Catholics and some Protestants to Dewart's book, see Gregory Baum, ed., The Future of Belief Debace (New York: Herder and Herder, 1967). On the specific issue of the hellenization of Christian doctrine, see the chapters written by Bernard J. F. Lonergan, "The Deshellenization of Dogma" (ibid., pp. 69-91), and R. C. Hinners, "The Challenge of Deshellenization" (ibid., Pp. 197-208). 
Be that as it may, it has become the widely accepted opinion that during the first centuries of Christian history there was a muvement from the Hebrew patcern of thought into the Greek, 1 and that in order to address the everyday experience of contemporary man both a "demythologization of Scripture" and a "dehellenization of dogma" are today most necessary. ${ }^{2}$

${ }^{1}$ A sharp contrast was drawn between Gieek and Hebrew ways of thinking by those Protestant theologians who, especially after the First World War, rejected the Idea that what is unbiblical or unrelated to the Hebraic thought might serve as part of the substristure of Christian theology. According to them, this contrast is manffested in the following points: (1) the divergence in the ontological realm between Greek staticism and Hebrew dynamism, (2) the difference in their method of reasoning between Greek abstract and Hebrew concrete thought, (3) the contrast between the Greek dualistic conception of man and the Hebrew view of man as $a$ unity, and (4) the distinction between "the divisive, distinction forming, analytic type of Greak thought and the totality type of Hebrew thought" (see James Barr. The Semantics of Biblical Language [London: Oxford University Press, 1961], pp. 8-20. See especially pp. 10-13). The issue of the "considerable disparity" between the Semitic and the Hellenistic ways of thinking, in particular about the notion of truth, has been much agltated and discussed in recent times as, for Instance, in Wolfhart Pannenberg's "Was ist Wahrhe1t?", in Vom Herrengeheimnis der Wahrheit: Festschrift für Hefnrich Vogel (Berlin and Stuttgart, 1962), pp. 214-239; and T. F. Torrance's "Die Wahrheit, wie Sie in Jesus ist," in ibid., pp. 254275. See also, among others, T. F. Torrance, "Truth and Authority: Theses on Truth, " IIO 39 (1972):215-242; John Macquarrie, Thinking ahout God (New York: Harper and Row, 1975), especially the chapter "Truth in Theology;" Rudolf Bultmann, " $\alpha \lambda \eta \dot{ } \theta \varepsilon L \alpha$," IDNT (1964), 1:238-247; Anthony C. Thiselton, "Truth," NIDNTT (1978), 3:874-902; E. T. Ramsde11, "The O.T. Understanding of Truth," JRel 31 (1951): 264-273; Y. Alanen, "Das Wahrheitsproblem in der Bibel und in der griechischen Philosophie," KerDo 3 (1957):230-39; Ignace de la Potterie, "De sensu vocis 'emet in V.T.," VerDom 27 (1949):336-54; and 28 (1950): 29-42; Idem., "L'arrière-fond du thème johannique de vérité," IU 73 (1959):277-94; Bruce Vawter, Biblical Inspiration (Philadelphia: Westminster; London: Hutchinson, 1972), p. 34.

2 So Dewart, The Future of Belief, pp. 49-50. Interestingly enough, Dewart does not believe that the hellenization of Christian theology necessarily meant the corruption of the gospel (see above. p. 100, especially n. 4). 
The historical way of thinking as

a norm of orthodory

The demythologization- and dehellenization-opinion just mentioned implies that the principle of authority which had traditionally expressed teself in the revelational and the ecclesiastical criteria of orthodoxy has been challenged as such. Indeed, the modern way of thinking is characterized by the questioning of traditional authoptetes and tradition in general, and the articula. tion of a new standard of truth. ${ }^{1}$ critlcism may be pointed out as the principle und ffilrding the modern approach to one's search for truth. In correl $a_{a}$ tion with this principle, the dominant criterion of truth of moder times can be described as the "scientific" criterion. It basfally means that the modern mentality tends to accept as true that which can be stated on the basis of an objective establishing of the facts.

In the socfal sciences the modern scientific criterion found concrete expression in the historicist world-view which, in general terms, sees truth extsting in the concrete dimension of history, in contradistinction to early Christians, who believed that they had found the truth $i_{n}$ the revelation of an eternal God, and classical Greek and Hellenis ${ }^{2}$ philosophers, who cilscovered the truth in the blossoming of the eternal in the spatio-temporal realm. Being a definite scientifie-Philosophical conception of reality, historicism is regarded here as a concrete nom of truth in which the scientific

$1_{\text {See Mich }}$ el Allen Gillespie, Hegel. Heidegger, and the Ground of History (Chicago \& London: University of Chicago Press, 1984), P. 8. See 2lso Rudolf Bultmann, The Presence of Eternity: History and Eschato10gy (New York: Harper Brothers, 1957), p. 7. 
criterion finds expression. Though "historicism" is a term whose meaning has undergone both considerable change throughout modern history and a very great diversity in usage (there are divergent historicist world-views ${ }^{2}$ ) it may be defined in general as the dynamic and temporalistic conception of the world ${ }^{3}$ which tends to view all knowledge and all forms of experience in a context of historical change and development. 4 It is used in this dissertation in its more general sense as the position which stresses the relativity inherent in circumstances involving time. place. "Weltanschauung," and other cultural variables.

In sum, the new historical way of thinking which characterizes the modern world, 5 involves a dynamic understanding of reality

IOn this particular matter, see Maurice Mandelbaum, "Historlcism," The Encyclopedia of Philosophy (1967), 4:22-25. for example.

2Take the divergent views of Hegel, Comte, Marx, and Spencer

${ }^{3}$ So Karl Mannheim, "Historismus," Archiv für Sozialwissenschaft und Sozialpolitik, vol. 52 (1924); Engl. trans. in Paul Kecskemeti, trans. and ed., Essays on the Sociology of Knowledge (London, 1952). Characterizing historicism as a basic "Weltanschauung, " Mannheim defines it as the temporalistic conception of the world which superseded the static world-ficture prevailing in the Middle Ages and, in a secularized form, in the Enlightenment. All social and cultural reality is now seen as dominated by change.

${ }^{4}$ So Ernst Troeltsch, Der Historismus und seine Probleme (Tübingen, 1922). Questioning Troelesch's and Mannheim's (see the preceding note) characterization of historicism as a world-view and suggesting that it should rather be regarded as "a methodological belief concerniag explanation and evaluation," Mandelbaum proposes the following general definition of that term: "Historicism is the belief that an adequate understanding of the nature of anything and an adequate assessment of its value are to be gained by considering it in terms of the place it occupied and the role it played within a process of development" (Mandelbaum, "Historicism, "p. 24).

${ }^{5}$ Maurice Mandelbaum, The Problem of Historical Knowledge: An 
(i.e., a non-static oritology) as well as a relativistic theory of knowledge. 1 It sees all knowledge, religious beliefs included, 2 as historically relative and culturally conditioned. The historfcal way of thinking also stresses the "one-worldly," temporal-historical, dynamic, and relative nature of reality over against the twoworldly (or "two-floors"), timeless-suprahistorical-metaphysical, static, and absolute theory of being which prevailed in the West until the Enlightenment as an inheritance of the classical Greek philosophy.

The new world-view led not only to reject the philosophical basis which had supported Christianity's system of theology for about elghteen centuries ${ }^{3}$ but to challenge the traditional criteria and norms of orthodoxy as well. It also put as far away as possible any supernaturalism. All this means that in consonance with the sctentfic cricerion of truth a new norm was offered to the theological community in the change of presuppositions which emerged in the Western world since the eighteenth century. This norm is identified with the historical consciousness prevalent in our age.

Answer fo Relativism (Freeport, New York: Books for Libraries Press, 1966, reprinted 1971), p. 1.

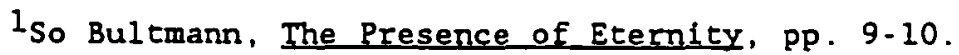

2 On the influence of philosophical presuppositions upon theological reasoning as one of the constants in the orthodoxyheresy antithesis, see above, PP. 25-27. One must underline, however, that the dependence of theology on philosophical presuppositions has came to the consciousness of some theologians only in very recent times.

${ }^{3}$ As already pointed out, this philosophical basis was seen from a modern perspective (particularly by liberals and Modernists) as provided by Greek philosophy (see above, pp. 96-98, passim). 
Science and history, notes Michael A. Gillespie, are the "two great intellectual forces in the modern world" which "while they often seem mutually antagonistic they are in fact fundamentally complementary." I In this way and only for the sake of convenience, without willing to compromise the distinction $I$ made between criterla and norms of orthodoxy, I speak of the "scientifichistorlcist criterion," thus referring both to the primary appreciation for the scientific criterion of truth and to the historical way of thinking characteristic of modern man.

In view of the preceding analysis, an answer to the question is to the causes of the modern objection to religious authority may be found, principally, in the change of the basic assumptions concerning the structure of reality and our knowledge of it which was brought about by modern philosophy starting with the eighteenth century. 2 From that century onward, when philosophers began to ask new questlons, ${ }^{3}$ the tension existing between the two classical norms of orthodoxy 4 undertook a more specific shape. 5 The new historical ix.

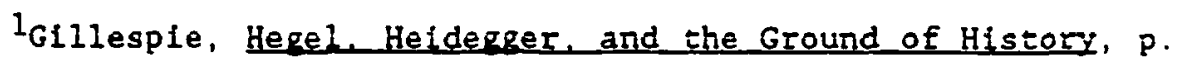

2Humanism and secularism, fostered by the Enlightenment, must be credited for this questioning of divine authority as well.

${ }^{3}$ In particular, regarding the way our mind knows. The presuppositions of an ontological and epistemological nature which were working at almost subconscious levels in earlier times now surface to the consclous layer. In philosophy, the theories of the nature of reality belong to the field of ontology, while those concerning the way the human mind performs the process of knowing belong to the philosophical division of epistemology, which was brought into existence $a s$ an independent and critical discipline by Emmanuel Kant's Critique of Pure Reason in 1781.

${ }^{4}$ Namely, the Scriptures and the living tradition. 
consciousness which gained momentum conceived this tension ds one between "the unique and non-recurrent word expressed by Christ and the manifold historical way in which this comes to us through the Church." 1 This tension involves, in sum, the duality of the timeless "essence" and the time- and culturally-conditioned "form" of Christian truth.

For some, the contention that religious beliefs are historicaily and culturally relative amounts to questloning the sertainty of the Christian message as a timeless truth of revelation. For others, the notion that the timeless truth of the Christian doctrine (its "essence") is expressed through historically conditioned theological propositions (its "form") appears as providing a plausible solution to the former persons' dilemma.

The new phflosophical and theological developments have compelled many Christians to rethink their concepts of divine revelation as the intrusion of eternity into the "lower" realm of nistory, of the inspiration of Scriptures as dictation. ${ }^{2}$ and even of the nature of God. ${ }^{3}$ The rejection of the old world-view in

${ }^{5}$ The new philosophical approach included the idea that the knowledge of truth does not merely depend on the object, but is relative to the subject. This epistemological turning point is identified in the history of philosophy with the work of Emmanuel Kant $(1724-1804)$.

1schoof, A Survey, p. 25.

2 This model of inspiration involves the to:al inerrancy of biblical piopositions.

${ }^{3}$ In the theological realm, the doctrines in which the ontological and the epistemological presuppositions are bound to be manifested more clearly are the docrines of God and revelation, respectively. 
philosophy corresponded to the denouncement of the "hellenization of Christianity" in theology.

The modern conflict regarding orthodoxy-and-heresy is not so much a clash between different doctrinal views, as in ancient Christian theolugy, nor a battle between different norms of orthodoxy, as in the confrontation of religious authorities at the time of the Reformation, but a struggle between two world-views. 1

Thus far the historical-theological outline of the development of the concept of orthodoxy has underlined the fact that the basic issue behind the first Christians' discrimination between true and false belief was the principle of authority. This was the principle undergirding the first criterion of orthodoxy which appeared in the history of Christian thought, namely, the revelational criterion: What made a particular doctrine true in the eyes of the early Christians was their conviction that the former was backed by the authority of divine revelation.

Al the time of the Protestant Reformation the validity of the principle of authority was not questioned. The dispute of those days was around the preeminence of either the revelational or the ecclesiastical expression of authority. More specifically, it was a controversy around the issue of "mediate authority, "2 whether the norma normans of orthodoxy was the Scriptures or the traditions of

$1_{\text {Karl }}$ Burger already noted at the turn of the century that "The question is whether Christianity is to maintain itself as the religion of revelation, or is to lapse to a mere phase of the general evolution of religious history" ( $K$. Burger, "Orthodoxy and Heterodoxy," NSchHerERK, 1910 ed., 8:278).

${ }^{2}$ See above, pp. 33-37, especially p. 36, n. 3. 
the church and the Magisterium's pronouncements. It is in the last two centuries that the principle of authority undergirding the revelational and the ecclesiastical criteria of Christian truth has been challenged as such.

This development has far-reaching implications. In the first place, it means that the traditional criteria of orthodoxy are being shaken. Second, and as a consequence of the former, it implies not merely that the whole approach of the first Christians to the issue of Christian truth has to be radically revised but also that the very categorles of orthodoxy and heresy are regarded as irrelevant. The reason for this is that the concepts of truth and error have acquired a more relative value, especially from an epistemological perspective.

\section{Orthodoxy and heresy: the present} state of the question

I suggested earlier that the epistemological relativity that dominates the scene in post-Kantian times has contributed to the modern objection to the principle of authority as weli as to the two criteria of classical orthodoxy in which that principle found expression. Since it is generally accepted that one's view on the subject of doctrinal authority--in particular on the issue of the existence of an objective nom of truth--affects the whole approach of one's theological reflection, this recent development has implications of major importance. As Rupert E. Davies observes,

Could it be demonstrated . . that there is no wholly authoritative source of religious truth, any distinction which may be held to exist between theology and philosophy would 
disappear, and the problems of theology would have been shown to be on the same level as the problems of metaphysics. 1

How does this reluctance to accept authoritative norms of religious truth relate to the present state of the orthodoxy-heresy antithesis? By the mid-twentieth century many have come to regard relativity as a main characteristic of that very issue as early as the second century A.D., if not before. This view was advocated by Walter Bauer's influential book on orthodoxy and heresy, ${ }^{2}$ in which the author holds that there has never been any objective, absolute standard of Christian truth. What came to be regarded as orthodox toward the fourth century was merely the opinion which predominated in the struggle opposing varfous Christian schools of thought, none of which was necessarily "true." 3 Though Bauer's argument was based on his reading of some historical evidences, it must be noticed that the conclusions derived from his findings on some Christian communities of the second century A.D. run parallel with the philosophical skepticism regarding absolutes prevalent from the nineteenth century on.

Following Bauer, an increasing number of scholars began to doubt the validity of the categories of orthodoxy and heresy. ${ }^{4}$ The

1 Davies, The Problem of Authority, pp. 9-10.

2 Bauer, Orthodoxy and Heresy. For bibliographical data about the original German edition (1934), see above, p. 30, n. 1 .

${ }^{3}$ It goes without saying that, according to the documents available today, this was far from being the view of early and even medieval Christians.

${ }^{4}$ Daniel J. Harrington wrote an informative article on the reactions aroused by the English translation of Bauer's book. See his "The Reception of Walter Bauer's Orthodoxy and Heresy in 
current situation seems to be well summarized by the contrasting positions set forth by theologians John Macquarrie and I. Howard Marshal1. Macquarrie, for one, underlines that "the concept of heresy has become a very elusive one." For that reason, "heresy trials are definitely an anachronism in the twentieth century, and the Christian communlty must find a more adult way of dealing with threats to the integrity of its faith."I to this theological objection to the use of the concept of heresy in the modern church, Marshall replies that

A church which takes its confession seriousiy must surely be prepared to speak out against what it believes to be error. and if necessary to discipline those who profess to uphold its confession while effectively denying or contradicting it. 2

This contention puts in evidence the relevance of the question of orthodoxy-heresy for contemporary theology. The basic theological issue of this antithesis, namely, religious authority, has surged to the forefront of today's theological debate in vircually all Christian denominations, not to mention the realm of ecumenism. ${ }^{3}$

Earliest Christlanity During the Last Decade," In HarvTR 73 (1980): $289-298$.

Macquarrie, Thinking about God, p. 44.

${ }^{2}$ Marshall, "Orthodoxy and Heresy," P. 14.

3 "The question of tradition and its near corollary, the question of authority, are not the only theological and ecumenical questions in the forefront of Christian concerns today, but it is safe to say that no significant issues can be sorted out, much less resolved," without attention to them, writes Patrick Henry ("Editor's Introduction," in Schools of Thought in the Christian Iradition [Philadelphia: Fortress Press, 1984], p. 1). 


\section{Summary and Conclusion}

Though summarizing a complex intellectual histury involves the risk of oversimplification, my brief treatment of the question of orthodoxy and heresy from a historical-theological perspective should have helped to highlight those criteria and norms of orthodoxy as well as those principles and theological issues considered to be central for our subsequent discussion.

It should be clear by now that the conflicts over some specific doctrinal points, mainly Christological at the beginning, served as a catalyst for the gradual development of certain criteria by which Christians sought to distinguish orthodox from heterodox belief and teaching. The main criteria of orthodoxy (or correct bellef) which appeared in the scenario of Christian theology were, first, the revelational criterion and then that which valued the ecclesiastical continuity of Christian tradition, i.e., the ecclesiastical criterion. These criteria contributed to identify some concrete norms of orthodoxy. The teaching of the apostles was the first such norm. As a consequence of the resognized teaching authority of the apostles and after their death, a Canon of neotestamentarian apostolic writings was recognized as sound norm. 1 The apostolic tradition was believed to exist also in an oral form which was kept and passed on by the disciples of the apostles. This is the principle of tradition. Controversies about who possessed the authentic oral tradition necessary to interpret

$1_{\text {When }}$ I speak of the "original apostolic tradition," I am, in fact, referring principally to the Scriptures of the New Testament. 
the canonicai scriptures correctly brought forth the idea that sound tradition was preserved, by the grace of the Spirit, in the catholic (universal) ecclesia, specifically in those churches which stood in the succession of the apostles. This idea constitutes what has been counted in this study as the second criterion of orthodoxy: the ecclestastical criterion. The oral traditions of the church constituted a concrete norm (the third norm of classical orthodoxy) in which the ecclesiastical criterion found expression. Those traditions were considered to be ozally summarized in the "rule of faith" or "canon of truth," which was in turn the forerunner of the written creeds of the early church. 1 From the ecclesiastical criterlon of correct doctrine, added to the recognized authority of the apostles, was later derived the fourth norm of orthodoxy: The bishops were increasingly regarded as the successors of the apostles, and thus the pronouncements of the episcopal Magisterium came to be regarded as normative.

A potential tension, which history proved later to be of major signiflcance, appeared between the two major criteria of orthodoxy. This tension consists in the confrontation between the normative authority of the Canon and the insights and truth claims of post-Biblical traditions that developed in the Christian communities, to which a normative status was also attributed.

Two theological issues are paramount in the Middle Ages. Due to both religious and political reasons, and thanks to the power

${ }^{1}$ Cf. Anthony E. Gilles, The People of the Creed: The Story Behind the Early Church (n.p.: St. Anthony Messenger Press, 1985), pp. $48-49$. 
reached by the episcopacy, the notions of the unity and catholicity of the church were emphasized. Ecclesiastical unity was enforced. The monolithic unity of the doctrine of the official church came only as a result of this development. In addition to the issue of the unity of the church's doctrine, the charismatic infallibility of the Magisterium was stressed in the atcempt at securing the truthfulness of the ecclesiastical teachings.

The principles, criteria, norms, and theological issues reviewed thus far should be regarded as the constitutive elements of the orthodoxy-heresy structure which appear clearly delineated toward the end of the Middle Ages. At that time heresy was defined not merely as false teaching but as a sin against church and state. indeed essentially as "non-church."

The Protestant Reformation constituted a revolutionary turning point in the history of the Christian church and theology. For one thing, the confrontation between the Catholic and the Protestant positions raised in a clear way the relativity of the concepts of orthodoxy and heresy. In relation with the issue of the general principle of authorlty we have the encounter of two mediate authorities or norms: on the one hand the canonical Scriptures, which constitute the original sources of Christian doctrine, on the other, the teachings of the Magisterium with its emphasis on the normativity of the living tradition. To both of these norms infallibility was ascribed.

From a more recent perspective, the change of presupposi-
tions or basic assumptions emerging since the eighteenth century has 
brought forth a new world-view which challenged some of the earlier concepts. A new hermeneutical criterion, i.e. the modern scientific criterion, ivuli expression in the historicist norm with its dynamic understanding of truth and reality and its appreciation for the relativity of knowledge. For one thing, the new criterion and norm challenged the classical and medieval static notion of reality and truth. For another, they moved the orthodoxy-heresy antithesis,

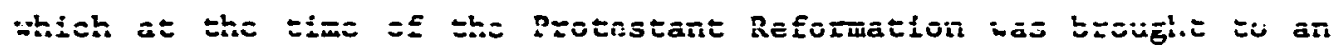
impasse, into another level different from that of the interaction between the object and the agent of theological knowledge, namely into the interpretative level. As mentioned earlier, 1 these three basic epistemological elements have always been present in the theological reflection of the Christian church. The historicaltheological outline presented in this chapter has made evident that through the history of the church there has been a shift in the stress laid on them. Specifically, the emphasis shifted from the revelational to the ecclesiastical criterion of orthodoxy. i.e., from the concern about what do Christians believe to the preoccupation about who has the teaching authority. Lately the emphasis has shifted again, this time from the ecclesiastical to the herweneutical criterion. It must be pointed out at this juncture that these three criteria of Christian truth are present in the theological reflection of all quarters in today's Christianity. The difference lays in the importance and ultimacy which each Christian community attributes to these criteria.

\footnotetext{
Isee above, PP. 87, 95-96; especially p. 96, n. 1.
} 
In the context of the hermeneutical criterion of truth the theories of the development of dogma became an important issue. They underlined the fact that many of the dogmas which the churches presented as eternal truths handed down essentially unchanged since the apostollc times had often had their origin in later historical circumstances. The concepts of doctrinal truth and error thus acquired a more relative value. As a result, the call for a nondogmatic and more pluralistic Christianity has brought to the fcreground the ldea of the inappropriateness of such concepts as orthodoxy and heresy. Thus, in modern times, among the theological issues related to the antithesis of orthodoxy-and-heresy, one may distinguish, mainly and foremost, the issues of the truth and infallibility of Christian doctrine and that of its continuity and change. They are related to the scientific criterion which measures both the object of theological knowledge and the agent interpreting and transmitting it against the norm constituted by the modern historical way of thinking.

One may find in the components of the orthodoxy-heresy antithesis here reviewed the loci of the analysis of Hans Küng's model of orthodoxy-heresy. Yet before one considers Küng's treatment of these components, in an attempt to better discern his views on this question, it is necessary to briefly delineate the main concerns and characteristics of his theology in general. This includes a succinct look at his formative years as a priest, during which one can already make out the general trends of Küng's theological thought. To this I now turn. 
CHAPTER II

HANS KŪNG, THE THEOLOGIAN

Since I consider useful for one's understanding of Küng's writings--in particular his view on heresy--an attempt to determine the leading concerns which constitute the starting point of his theology, this chapter brlefly describes and analyzes those concerns in the context of the most important elements which define him as a theologian. It includes a consideration of the formative years of his priestly education and some significant shifts in his theological development as well. I deem essential to deal with these matters first in order to appropriately interpret küng's statements concerning the orthodoxy-heresy antithesis and its subsidiary Issues.

As a young Swiss Roman Cathollc, Küng was "brought up in the traditional Catholic way and moulded by the Catholic youth movement." 1 After receiving what he considers to be, in contrast 1These are Kung's own words in Hermann Haring and Karl-Josef
Kuschel, "An Interview with Hans Küng, " [hereafter quoted as
"Interview"], in idem, W\&W, pp. $129-30$. Küng conceded to a long and
Informative Interview with his colleagues of the Eberhard-Karls-
Universitat of Tubingen, Hermann Haring and Karl-Josef Kuschel, in
1978 . Dr. Haring, born in 1937 , was at that time Academic
Counsellor at that University's Institute for Ecumenical Research
(Institut für okumenische Forschung) of which Hans Küng was
director. Dr. Kuschel, born in 1948, was Scientific Adviser at the
same Institute. This interview was later published in w\&W, a book
which its editors intended as " modest present for Hans Küng on his
Elftieth birthday," and as a token of gratitude "from pupils to 116 
with this traditional environment, a more liberal and modern education at the Gymnasium in Lucerne, ${ }^{1}$ küng went to Rome in 1948 to

thei: master, from scaff to their 'boss'n (see W\&W, pp. 2, 9). As expected, the two editors could not help ravealing cheir admiration for the ix "zuss." This, according to Donald D. Smeeton, "shows clearly in the framing of the questlons" of the interview (see Smeeton's review of Haring and Kuschel's book in TSF Bul, October 1980, p. 14. Smeeton was at that time a doctoral student at the Catholic University of Louvain, Belgium). Similarly, Gabriel Fackre points out that Haring and Kuschel trace the development of Küng's work by using essays "from admirers and friendly critfcs addressed to the varfous stages of his thinking" (Review of Hans Küng: His Work and His Way, in TSF Bul, Nov.-Dec. 1982, p. 18). Even though this book on Hans küng might be considered one-sided (the interview in particular), it constitutes the basis for the biographical information concerning the theologian in most of the works which deal, however briefly, with this aspect of his career (for instance. Kiwiet, Hans Küng, and Swidler, Küng in Conflict). David L. Mueller evaluates the interview as "the single most helpful section of the book for interpreting how Kung views his own theological pilgrimage and theological contribution" (see review in RevExp 78 [1981]: 127). On the other hand, in answer to the specific question regarding the existence of any additional sources dealing with the formative perlod of his priestly life, Kung states: "Mehr Quellenmaterial biographischer frt gibt es nicht, ist hier auch nicht von Bedeutung" (see letter of Enrlque Espinosa to Hans Küg, May 14, 1987; and letter of Hans kung to Enrique Espinosa, June 2, 1987. Both letters are deposited at the Adventist Heritage Center of Andrews University's Library, in Berrien Springs, Michigan).

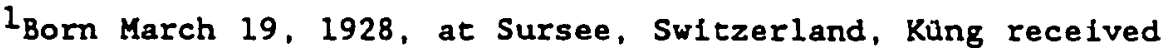
his Matura (secondary school certificate) at age 20 at the cantonal Gymasium in Lucerne, in 1948. See "Chronological Summary, 1928$1978^{\prime \prime}$ in WEW, p.12. For the most complete biographical information on Küng to date, see WEW, Pp.12-31. The long interview conceded to his collaborators Hermann Haring and Karl-Josef Kuschel (ibid., pp. 129-183) also provides blographical information unavailable elsewhere. Other works dealing with some aspects of Küng's blography are Contemporary Authors: A Bio-Bibliographical Guide to Current Authors and Their Works, vols, 53-56, ed. Clare D. Kinsman (Detrolt: Gale Research, The Book Tower, 1975), Pp. 354-55; Current Blography Yearbook: 1963 , ed. Charles Moritz (New York: $H . W$. Wilson, 1964), PP. 227-29; The International Who's who: 1982-83, 46 th ed. (London: Europa Publications, 1982), p. 729; G. H. Duggan, Hans Küng and Reunion (Westminster, Maryland: Newman Press, 1964); James M. King, "Hans Küng's Concept of Authority" (Ph.D. dissertation, Southern Baptist Theological Seminary, 1981), pp. 4-25; Kiwiet, Hans Küng, Pp. 15-30; Nowe11, A Passion for Truth, pp. 2055 ; and Swidler, Küng in Conflict, pp. 1-8. 
be trained at the Pontifical Gregorian University in a system of education which he describes as being "in the strict Tridentine spirit." It would span a total of seven years. I It yas during those years (1948-1955) that his leading theological concerns began to take shape. ${ }^{2}$

\section{Küng's Pastoral Vocation}

Kung went to the Gregorian University in search of a preparation for "the active pastoral work that I hoped to undertake in one of the bigger cities... as a parish priest."3 The importance of the fact that küng saw his scholarly training not as preparation for academic work at a University but as education for an active pastoral ministry cannot be overstated. As is suggested more than once in this dissertation, that pastoral concern should be seen as the basic characteristic of his theological career. ${ }^{4}$

InInterview," p. 131. During the years of his studies in Rome küng found lodging in the German College (the Germanicum) which, like the Gregorian University, was under the auspices of the Jesuits (see Kiwiet, Hans küng, p. 16). After three years study of philosophy at the Gregorian, he was granted the degree of Litentiate of Philosophy (his dissertation on the atheist humanism of Jean-Paul Sartre). The following four years küng studied theology at the same university, obtaining the degree of Litentiate of Theology in 1955 after defending a dissertation on Karl Barth's doctrine of justification, supervised by Maurizio Flick (see W\&W, Pp. 12, 14).

${ }^{2}$ küng affirms that "without a doubt my seven years in Rome had a lasting effect on my basic attitudes. The fundamental decisions, too, did not, as is often believed, take place in Paris or in Germany but in Rome" ("Interview," p. 135).

3 "Interview," p. 131.

${ }^{4}$ Kiwiet observes that "pastoral care and theologicai concern would gradually merge into a genuine pastoral theology as one finds demonstrated in Küng's bestseller, On Being a Christian (1976)" (Kiwiet, Hans Küng, p. 18). 
While studying in Rome, Küng had the opportunity to fulfill his pastoral vocation working as chaplain to the Italian employees of the German College where he lived. In that capacity he persistently sought to improve the social conditions of his flock, which brought him into conflict with the college authorities. 1 Later on, while studying in Paris (1955-1957), ${ }^{2}$ Küng assumed the pastoral care of the numerous Swiss girls who, in order to improve their knowledge of French, were Iiving with French families in that capital city. ${ }^{3}$ After gaining his doctorate of theology in Paris (February 1957), 4 he was called to pastoral work as assistant priest at the Hofkirche in Lucerne (1957). Küng describes the eighteen months he spent in that ministry as "a short but very pleasant time."5 It was time

InInterview," pp. 133-34. Swidler, for his part, observes that this incident provided küng with an insight into the practical need of reform even at that level in the Roman Catholic Church (Swidler, Küng in Conflict, $p$. 3).

${ }^{2}$ Ac Paris Küng attended the Institut Catholique and the Sorbonne (see WGW, p. 14; cf. Kiwiet, Hans Küng, pp. 19-20; and Swidler, Küne in Conflict, p. 3).

3ninterview," p. 153.

"Kung's Doctor of Theology degree was granted by the Institut Catholique de Paris, the Catholic university of the French capital city (see Kiwiet, hans Küng, p. 23; also Swidler, Küng in Conflict, p. 1). His doctoral dissertation, supervised by Louis Bouyer, was entitled "Justification, la ductrine de Karl Barth et une réflexion catholique" (W\&W, P. 14). It was in Paris that Küng met Barth for the first time, though his study of Barthian theology started years earlier. His interest in the Reformed theologian was encouraged by Hans Urs von Balthasar, who also published Küng's doctoral dissertation in a German translation "from his Johannes. Verlag," as Küng puts it, simultaneously with the author's gaining the doctoral degree. This was Kung's first published book (see W\&W, pp. 138, 187; cf. Kiwiet, Hans küng, p. 157, n. 49).

$$
\text { Sninterview," p. } 153 .
$$


enough, says he, to enable him to have "a clear picture" throughout his entire life of "the practical problems, anxieties and needs of the pastoral clergy."1 He discerned "how important a good theological preparation is for pastoral work in practice, for proclaiming the word, for preaching, for giving instruction. "2 When invited, in 1959, to begin his academic career as sciencific assistant for Dogmatic Cathollc Theology at the University of Münster In Westphalla, Germany, ${ }^{3}$ Küng was well equipped to train prlests, attending to both their theological and pastoral needs. As in many other cases of frultfü theological endeavors. Küng's theological reflection had at its foundation a practical, pastoral concern. 4 In fact, it may be affirmed that, in a very important sense, Christian theology is not an intellectual exercise to be

1 Ibid.

2Ib1d., Pp. 153-154. Commenting on Küng's judgment about the influence of parish experience on his career, in particular the fact that pastoral work provided him with a test of "how applicable a particular theology was," Fackre remarks: "Some pastors may think back on their second year certainties and wonder a bit about this" (ISF Bul, Nov. -Dec. 1982, p. 18).

${ }^{3}$ Küng was assistant to professor Hermann Volk, who eventually became the Cardinal Archbishop of Mainz. To him, as well as to Karl Rahner and Heinrich Fries-whose successor he became in 1960 at the University of Tubingen--the author owes his having opted for the academic life in Germany (see Swidler, Küng ir Conflict, p. 4).

${ }^{4}$ Küng himself affirms, for instance, that what led the first ecumenical councils to define the Christological dogmas "was not joy in theological speculation or in development of dogma, but pastoral concern" (Küng, On Being a Christian, trans. Edward Quinn (New York: Wallaby Books, Simon \& Schuster, 1978], p. 448; hereafter referred to as Küng. Christian). 
performed outside the bosom of the church and, therefore, in disconnection with the religlous, spirftual concerns of its members.

\section{Küne's Pastoral and Theological Concerns}

Küng's schooling at the Lucerne Gymnasium led him to open up to modern culture, to "contemporary intellectual life in general." 1 Added to his natural "boundless intellectual curiosity that can never be satiated," 2 this sensitiveness to the activities and concerns of modern human beings yielded one of the main undergirding characteristics of Küng's theology. One of his constant preoccupatfons has findeed been to make the Ohrlstian wessage meaningful and relevant for his contemporary fellow-human beings. ${ }^{3}$ $129-130$.

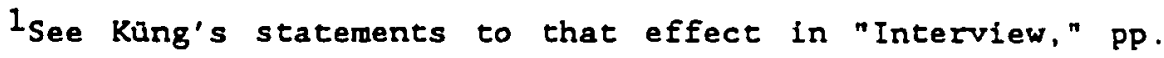

2Ibid., p. 129.

${ }^{3}$ In many ways and places, Küng expresses his concern for making the Gospel relevant to modern humanity. Here are just a few examples. Speaking of the theology of the First Vatican Council, which he labels as "neo-scholastic," or "Vatican Denzinger Theology," Kung writes ti:t: "The Second Vatican Councll demonstrated that this theology was unable to deal effectively with the contemporary problems of humanity, rie Chure', and society" (Küng, "New Consensus," p. 1). "Theolozy has to establish a critical correlation between traditional Christian experience and contemporary experience. . . . An alien conceptual system does not aid us in proclaimfing the Gospel to modern humseity" (ibid., $\vec{p} \bar{p}$. 12-13). "Catholic theologians. . . will certainly pay attention to Rome. And they will do it even gladly whenever constructive, helpful, and reasoned answers are given to the needs and hopes of these times" (Küng. "Incapable of Learning? Roma locuta, causa aperta," in Swidler, Küng in Conflict, p. 91).

The same concern appears in different forms throughout most of his books. See, for instance, That the World May Believe, trans. Cecily Hastings (New York: Sheed and Ward, 1963) [hereafter referred to as Küng, May Believe], which, written in 1962, was Küng's third book (Damit die Welt glaube; Briefe an junge Menschen [Munich: J. Pfeiffer]). See also Hans Küng, Josef van Ess, Heinrich von Stietencron, and Heinz Bechert, Christentum und Weltreligionen 
His studies in Lucerne provided küng with another opportunity, that of coming into contact with fellow-classmates of Catholic, Protestant, and Jewish persuasions. 1 A greater awareness of the concerns and bellefs of non-Catholics began to come into focus in his own set of concerns and beliefs. During his final years in Rome sometime later, "there was the intensive study of Protestant theology in the form of Barth's Church Dogmatics." 2 All in all, his studies in Paris at the Sorbonne and the Institut Catholique, as well as his "extended visits" at that time to spain, England, and Holland, helped küng to deepen his ecumenical understanding of Christianity.

During those formative years, he also came into contact with the so-called French nouvelle theologie, ${ }^{3}$ on the one hand, and in close personal relationship with the Protestant theologian Karl

(Munfch: Piper Verlag, 1985), tranlated into English by Peter Heinegg: Christianity and the World Religions: Paths of Dialogue with Islam. Hinduism, and Buddhism (Garden City, New York: Doubieday \& Company, 1986) (hereafter referred to as küng et al.. World Religions]; cf. Hans küng and Jürgen Moltmann, eds., Christianity Among World Religions, Concilium (Edinburgh: T.\& T. Clark, 1986).

InInterview," p. 130; cf. Kiwiet, Hans Küng, p. 15.

2 "Interview, " p. 130 .

${ }^{3}$ For further reference to this theological school, see below, p. 130, n. 2. See also Küng, Does God Exist? An Answer for Today, trans. Edward Quinn (Garden City, New York: Doubleday \& Co., 1980), pp. 518-19; [hereafter referred to as Küng, Does God Exist?]. A treatment of the "New Theology" is found in chapter 8 of Walther von Loewenich's Modern Uatholicism, trans. Reginald H. Fuller (New York: St. Martin's Press, 1959), pp. 240-64. According to Loewenich, the term was coined by Pope Pius XII in an allocution delivered in 1946 that recommended Jesuit theologians not to accept a "new theology" which must be in constant transformation, thus threatening the unity and stability of the Catholic Faith and the unchangeability of its dogmas (ibid., pp. 243-44). 
Barth, on the other. ${ }^{1}$ Indeed, the major purpose of Küng's doctoral dissertation on the Barthian doctrine of justification was to demonstrate that there is a "fundamental agreement" between the doctrine of justification in Barth and Roman Catholicism, when the latter is "correctly understood." 2 The matter was of no minor importance since it was

. . well known to me that according to the general view all the differences between Catholic and Protestant theology and between the Cacholic and Piotestant Churches were based on their different understanding of justification. ${ }^{3}$

It appears that in fact küng was attempting to reconcile the theologies and religious lives of Roman Catholics and Protestants. ${ }^{4}$ Here lies the second main trait of his theological work. In addition to his preoccupation for the proclamation of the Gospel in terms both intelligible and relevant to modern humankind, he aimed to achieve an ecumenical understanding among all Christian traditions, 5 and later on, between Christlanity and other world-wide religions.

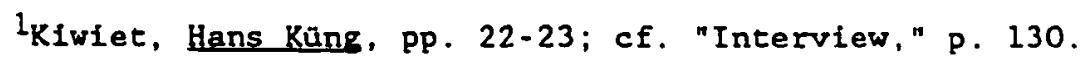

2nInterview," p. 139 (these are küng's own words).

${ }^{3}$ Ibid.

"Kiwiet describes Kūng as a "mediator between two camps" because of his attempt to reconcile Protestants and Catholics, and later on the traditional Roman Catholic theology with secular scholarship (see Kiwiet, Hans Küng, p. 126).

Ssee, for instance, Kung's concern for the unity of the church in the sections "The Church as the Body of Christ" and "The Church Is One" of his volume The Church, Pp. 266-337, 341-383.
} 
The Starting Point of Küng's Theology

The two main concerns, pastoral in nature, which we reviewed thus far, undergird Küng's theological activity. They compel Küng to contend with two issues often regarded as stumbling blocks for modern-minded men and women, as well as for the ecumenical movement that he has fervently promoted. These two issues are, respectively. some "errors" found both in the dogmatic pronouncements of the Magisterium and in the text of the Scriptures on the one hand, $l$ and the Roman Catholic model of ecclesiastical authority with its stress on the infallibility of the Magisterium, on the other. Both constitute serious problems for the contemporary mind and a major obstacle for the achievement of theological understanding between Roman Catholics and most separated churches. 2 As shown in chapter

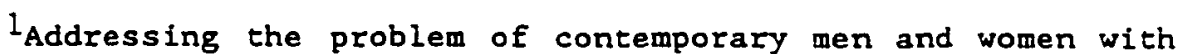
respect to faith in one of his major works, küng states: "This book is written. . . for those who do not believe, but nevertheless seriously inquire; who did believe, but are not satisfied with their unbelief; who do believe, but feel insecure in their faith; who are at a loss, between belief and unbelief; who are skeptical, both about their convictions and about their doubts" (Christian, p. 19).

${ }^{2}$ Consider, for instance, the "Agreed sratement on Authority in the Church" issued in Venice on January 20, 1977, by the Anglican-Roman Catholic International Commission (ARCIC), 3 commission created as a resuit of the initiative of Pope Paul VI and Arthur M. Ramsey, Archbishop nf Canterbury (see ARCIC, The Final Report [Cincinnat1: Forward Movement Publications, 1982], pp. 103104). Article 24 of the so-called "Venice statement" points out that some problems still remain for a complete agreement concerning papal primacy, among which is papal infalibility (for the complete text of the Venice Statement, see The Final Report, pp. 52-67). These remaining difficulties were addressed in the "Second statement on Authority in the Church," issued in Windsor, on September 1981 (see the complete text in the Final Report, pp. 81-98). It asserts that Anglicans do not accept the guaranteed possession of infallibility in judgment necessarily attached to the office of the bishop of Rome (see articles 31 and 32). In the Lutheran-Catholic dialogue which began in July, 1964, the longest debated issue was, by far, 
one, both are a!ss directly related to the issue of orthodoxy-

heresy. In most of his books küng attempes to formulate a solution to these two problems. 1 Indeed, his interest in the plight of

the "Teaching Authorfty and Infallibility in the Church," which required nine meetings over a span of five years (1973-78). Even though they achieved "a degree of mutual understanding," Catholic and Lutheran participants did not reach a full agreement in these talks. Indeed, the hope is expressed that "further progress toward resolving this difficult issue" will be made in the future (see Paul C. Empie and T. Austin Murphy, Co-Chairmen's "Preface," in P. C. Empie, T. A. Murphy, and Joseph A. Burgess, eds.. Teaching Authority \& Infallibility in the Church: Lutherans and Catholics in Dialogue VI [Minneapolis: Augsburg Publishing House, 1980], Pp. 6-7). Lutherans continue rejecting papal infallibility (see "Common Statement on Teaching Authority and Intallibility in the Church," art. 52). They see the Ministry of the bishop of Rome as "a service under the authority of the Word of God" (ibid., art. 53). For the complete text of the "Common Statement," see Empie, Murphy, and Burgess, eds, Teachine Authority, Pp. 11-38. From a Roman Catholic perspective, the "Common Statement," particularly arts. 52-53, "seeks to place the doctrine of infallibility in the theological categories of promise, trust, and hope rather than in the juridical categories of law, obligation, and obedience" (ibid., p. 39).

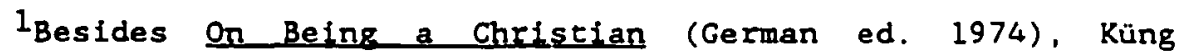
addresses the problem of modern urbelief and the doctrine of the church in That the World May Belleve (German ed. 1962); Freedom Today, trans. Cecily Hastings (New York: Sheed and Ward, 1966); Gott und das Leid (Einsledeln, Zurich, and Cologne: Benziger Verlag, 1967); Menschwerdung Goties (1970); Freud and the Problem of God, trans. Edward Quinn (New Haven: Yale University Press, 1979); Does God Extst? (German ed. 1978); Eternal Life? Life after Death as a Medical. Philosophical and Theological Problem, trans. Edward Quinn (Garden City, New York: Image Books, 1985) [quoted henceforward as Eternal Life?]; Küng et al., World Religions (German ed. 1985); and Theologie im Aufbruch: Eine okumenische Grundlegung (Munich: $R$. Piper Verlag, 1987), hereafter referred to as Küng, Theologie im Aufbruch.

The issue of ecclesiastical authority, in particular the infallibility of the Magisterium, has been treated in the Council. Reform and Reunion, trans. Cecily Hastings (New York: Sheed and Ward, 1961) [quoted henceforward as The Council]; Structures of the Church (German ed. 1962); The Council in Action: Theological Reflections on the Second Vatican Council (Published in Great Britain under the titles The Living Church (1963), and The Changing Church (1965)], trans. Cecily Hastings (New York: Sheed and Ward, 1963) [hereafter referred to as Council in Action]; The Church (German ed. 1967); Truthfulness: The Future of the Church, trans. 
secular man and in the reciprocal understanding of Christians of different persuasions is clearly apparent from the very start of his scholarly career. His thesis for the Licentiate in Philosophy, written under Alois Naber (Rome, 1951), for instance, addressed the existentialist philosophy of Jean-Paul Sartre; while his doctoral dissertation, as we noted, was devoted to the study of the fundamental agreement between the Protestant (in its Barthian form) and the Catholic doctrines of justification.

At the same time, however, a change of emphasis was raking place in Küng's literary production. Even a cursory look at the list of his publications shows that during the sixties and early seventies most of them focused on eccleslological issues. They were to become more immediately related to the concerns of contemporary humanity in general during the late seventies and eighties. 1

This should not be understood to mean that Küng regards his earlier concerns as unimportant. 2 He merely felt that he had "had

Edward Quinn (New York: Sheed and Ward, 1968) [hereafter referred to as Iruthfulness]; Infallible? An Inquiny, trans. Edward Quinn (Garden City, New York: Doubleday \& Co., 1971) (quoted henceforward as Infallible?]; and Was in der Kirche bleiben muss (Zurich, Einsiedeln, and Cologne: Benziger, 1973), hereafter referred to as Blelben muss.

1Already in 1978 Küng observed: "I have increasingly turned from internal Church problems to devote myself to the problems of contemporary men and women, of contemporary science and scholarship, and of contemporary society" (see "Interview," p. 182; cf. the recent retrospective description of his own theological development in Küng, "On Being a Christian Theologian," The Critic [Summer 1987]:11-16).

In the "Interview" ( $p .182$ ) he announced his plan to write a couple of books on the sacraments and on grace. 
enough of continually defending myself against bishops and their tame theologians. 1

\section{At the Core of Küng's Pastoral and Theological Concerns}

Küng's relentless preoccupation with Christian unity and Christian witnessing to the modern world seems to have been the result of an increasing conviction that his church had been addressing these issues in an unsuccessful manner.

The author, in fact, explicitly points out that in his view Roman Catholicism falls short of accomplishing what he thinks is its Christian dury. In ecclesiological macters, for instance, one of his theses is that his church has failed to recognize the other Christian churches as churches. ${ }^{2}$ In relation to society in general, he affirms that it has not been much more successful either in addressing the questions of modern men and women. ${ }^{3}$ In addition, and closer to the orthodoxy-heresy issue, he states that his church must recognize that on moro than ano ocsesien it has been wrong in lts doctrine. 4

$1_{\text {Ibid. }}$

${ }^{2}$ Kung recognizes that this attitude on the part of the Roman Catholic Church toward ocher Christian churches has significantly changed at Vatican II, "although there are still some ambiguities" (The Church, pp. 365-67).

${ }^{3}$ The theology that dominated the scene between the first and second Vatican Councils, argues Küng. "was unable to deal effectively with the contemporary problems of humanity, the Church, and society." Although not completely overcome by Vatican II, judges he, that theology's "absolute theological hegemony" was ended as a result of this Council (Küng, "New Consensus," p. i).

${ }^{4}$ Küng. Infallible?, p. 31. 
This contention appears early in Küng's writings. One can detect it already in his years of ministerial training, particularly during his studies in Rome. 1 The slow process which led him to challenge Roman Catholic teaching crystallized some time after his first five years in Rome, i.e., between 1953 and 1955, in regards to some specific issues. 2 These fall into two categories, namely. matters of discipline and theological issues. Let us briefly consider each of them.

\section{Issues of a disciplinary nature}

Toward the end of his studies in Rome, Küng found college discipline increasingly questionable. In the context of thenuncommonly strict rules of the German College" which students regarded as a "Tridentine regulation of their entire life," the theologian points out that he called in question "the obligation to have to

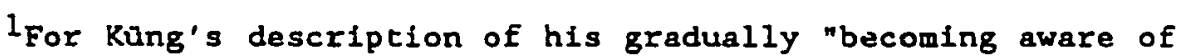
certain definite problems" during his studies in Rome, and the subsequent effect on his theological concerns, see "Interview," pp. 132-37. The discussion that follows owes much to these pages. For that reason, no further references seem necessary for every single quotation. Since there is no other source on Küng's theological evolution during this period of his career, I have come to rely on his personal account of what happened (regarding the absence of additional biographical material dealing with this particular period of his life, see Küng's letter cited above, p. 116, n. 1).

2 According to Küng's own account, the process of finding Roman Catholic theology and discipline questionable "crystallized out in certain issues and indeed conflicts." These are basically four and are analyzed in the following pages under the subheadings "Issues of a disciplinary nature," and "Issues of a theological nature." For Küng's description of these four issues, see "Interview," pp. 132-34. No further references are given on pp. 128-34 below, when quoting from this specific source. 
attend lectures when one could have read their contents up much more quickly in text-books."

In Küng's own estimation, this was his first test case of ecclesiastical obedience. Was he to follow the system or his own personal convictions? The issue is appreciably more important than it may seem at first glance. The problem of keeping a balance between their personal convictions and the system of the church to which they belonged has proven to be a difficult one for many = Christian. In fact, important breaches in the history of the church have had their origin in an individuai's decision to follow his own convictions instead of those that a particular system imposed upon him. Not infrequently what resulted in a orthodoxy-heresy theological issue started as a problem of personal relations. often enough, this was a matter of discipline and policies regarding affairs hardly related to the theological world.

Another issue of disciplinary nature which brought küng into conflict with the college authorities was briefly mentioned earlier. It relates to his involvement with the chaplaincy of the Italian employees of the college.1 on this specific point küng observes that he "saw it as part of my job to intervene on their behalf," to get an improvement in their conditions regarding accommodation, pay. and even the possibility of getting married. 2 Once more, ecclesiastical policies of a practical nature were leading him to shallenge the church system at a particular point.

\footnotetext{
${ }^{1}$ See above, p. 119.

2 "Interview," p. 133.
} 
Issues of a theological nature

Interestingly enough, these inquiries occurred at a time when Küng was also raising questions regarding some aspects of Roman Catholic theology. The latter are basically two and deal with what Küng calls: (1) "the crisis of Church ieadership," and (2) the "twotier" way of looking at the relationship between the natural and the supernatural worlds.

One should keep in mind that küng studied in Rome during the final years of pope Pius XII, who was then "at the pinnacle of his power and reputation." The young Swiss student was thus able to look every day "behind the scenes of this pontificate," a fact which, in the words of Kung, eventually brought about "a demythologization of this Pope whom formerly we had all idealized." Küng explains his disappointment concerning the teaching authnrity of the pope in the following terms:

There was continuous inflation of statements by the Church's teaching authority in the form of addresses and encyclicals by a Pope who had learned it all by heart and who ended up by merely seading what had been written by others who I happened to know only too well. 1

This disturbing fact must be understood against the background of "the display of papal pomp and ceremony" that was taking place at the time, "the triumphalist definition of the Assumption" in 1950, and, in the same year, the publication of the encyclical Humani generis directed against what the Magisterium regarded as theological deviations. 2 Catholics like hans küng

I Ibid.; cf. Küng, Does God Exist?, p. 520.

${ }^{2}$ Humani generis, issued August 12, 1950, condemned the 
131

tended to dispute--for reasons which I shall consider later--such expressions of papal infallibility as well as the Magisterium's definition of errors.

To attribute küng's critique of the ecclesiastical system to some personal defects-of which he complains to have been Erequently accused--such as "a desire to parade my own peısun, iaking myself too serfously, a lack of humility, an unwillingness to listen to reason, thoroughgoing obstinacy, etc." seems somewhat of an oversimplification. His initial attitude, indeed, was not one of stubbornness or unwillingness to submit to church authorities. He went to Rome "completely voluntarily and in full knowledge of what lay in store," precisely looking for a "contrast to the worldliness and freedom" he had been enjoying till then. In fact, at the beginning of his studles in Rome, he "used to criticize the 'arrogance' and the 'mania for criticism'" shown by German professors of theology who expressed doubt on the doctrine of the bodily assumption of Mary. On the basis of "the organic theory of the development of dogma ${ }^{2}$ being served up to us at that time," explains

methods and many of the conclusions of the so-called "new theology" (nouvelle theologie) that was born in France toward the end of the Second World War, and which criticized the two-tler theory and neoscholasticism in general (see Küng, Does God Exist?, Pp. 518-20). For further reference to the "two-tier theory," see below, Pp. 133. 135, especially p. 133, n. 1 . For additional reference to and quotations from the mentioned encyclical, see below, pp. 284-285, especially p. $285, n$. 1 .

\section{InInterview," p. 137.}

2 On the "organic theory" of development of dogma, see above. PP. $88-91$. 
Küng, the definition of the new Marian dogma struck him "as a suitable expression of the Catholic understanding of the faith."

If indeed küng began by thus identifying himseif with the Roman Catholic theological system ${ }^{1}$ with very few reservations, to the point where he did not understand at all the freer attitude of his older fellow-students who "just could not come to terms with this Tridentine regulation of their entire life," the breach that came later can hardly be charged totally to his temperameitt ${ }^{2}$ or even his "Swiss appreclation of freedom and independence." 3 what has been discliscd here mist te retained as an illustration of the main reason for his change of attitude.

The second theological issue which inclined küng to question the Roman Catholic theological system was what he calls "the development of theology." What he seems to have first called in

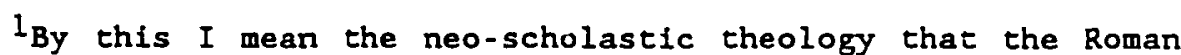
Catholic Church officially held, particularly before the second Vatican Council. For Küng's subsequent objections to this theology, see, for instance, Maintained, pp. 42-43.

${ }^{2}$ St111, Father Joseph F. Costanzo, also a Jesuit, describes Küng's challenge to traditional Catholic ecclesiology as a symptom of "teutonic neuralgia. . . . The monotonous frequency and vartations on Romanism and neo-scholasticism--adds he--reveals not only a psychological alienation but also an intellectual turning of the worm" (Costanzo. The Historical Credibility of hans Kung [sic]: An Inquiry and Commentary (North Quincy, Massachusetes: Christopher Publishing House, 1979], Pp. 11-12). Frank Morriss finds Küng "arrogant" and expresses his annoyance toward Küng's attitude in the following terms: "Rather than listing himself in the company of some distinguished atheists and subjectivist philosophers, Kueng should list himself in the company of the petty, virulent, and bigoted preachers who have for saveral centuries called the Church antiChrist and the whore of Babylon" (Morriss, "Hans Kueng's Call for Rebellion," The Wanderer, October 31, 1985, p. 4).

3nInterview, " p. 137 ; cf. Kiwiet, Hans Küng, p. 15. 
question was the "neoscholastic system of theology," which later he criticized on various occasions. More specifically, he questioned "what can best be described as the neoscholastic two-tier way" of looking at theological questions. I küng had major difficulties with the two-tier division between the natural and the supernatural realms, as well as between reason and faith, nature and grace. ${ }^{2}$ A first attempt at criticizing this theory had already been made by Henri de Lubac $^{3}$ and the theologians--mostly French--of the nouvelle

1nInterview," p. 133. Lutheran theologian George A. Lindbeck notes that the theological view of the universe in which there is a relatively static, perpendicular contrast between two distinctly separated levels of created reality, "an fmmaterfal and timeless heaven above, and the realm of temporality and matter beneath." is popularly caricatured these days as a "two-story" theory of the universe (Lindbeck, "A Protestant point of View," in Vatican II: An Interfaith Appraisal, ed. John H. Miller (Notre Dame and London: University of Notre Dame Press, 1966], pp. 220-21). This two-tier theory, or "two-floors theory" (see Küng. Does God Exist?, p. 518) postulates a division between the natural and the supernatural planes which supposes both a natural and a divinely revealed way af knowing God (reeson and faith). Hence it is held that human reason, unaided by divine revelation and grace is able to demonstrate from created things the existence of a personal God. This view was sanctioned by $\mathrm{Va}:=3=$. I and by Pius XII's Humani generis (see Denz, 3890-91; cf. Küng, Does God Exist?, pp. 509-22).

2 kung credits his book Justification with being "the first time that the two-tier theory with nature providing the foundations and the supernatural the superstructure had been overcome. . . . From start to finish the 'natural/supernatural' terminology was avolded, . . and more down-to-earth language was used to replace it. So one was no longer talking about human nature but about human beings, about peoplen ("Interview," p. 140). Similarly, in Justification Küng was no longer talking about "the various graces as accidents but about the effectively gracious God." The so-called "two-tier theory," built upon the Hellenic conceptual system, began to be overcome after Vatican II, notes kung, once produced the collapse of the neo-scholastic system and the starting of the "programme of dehellenization" of the Christian faith in the Roman Catholic Church" (Küng, Menschwerdung, p. 646).

${ }^{3}$ Henri de Lubac, Le surnatureli Etudes historiques (Paris, 1946), quoted in Küng, Does God Exist?, p. 518. 
théologie, a new theological school to which Yves Congar, Jean Danièlou, Marie Dominique Chenu, and Hans Urs von Balthasar (a Swiss), among others, belonged. ${ }^{1}$ In Germany, Karl Rahner also was finding fault with the two-tier theory, which brought him into conflict with the Roman Catholic Magisterium. ${ }^{2}$

One should not fail to keep in mind that by that time küng had given careful study to the difficult and comprehensive works of Hege $1^{3}$ and Barth, ${ }^{4}$ which confirmed his criticism of the two-story theory. He makes it clear that indeed the most relevant censure of this philosophical-theological approach (the two-tier theory) came from outside Roman Catholicism, as from the Protestant theologian Karl Barth, for instance. 5 Likewise, the speculative philosophy of Hegel--which Küng describes as the place "where faith and reason are

$1_{\text {See above, p. } 122 \text {, especially n. } 3 .}$

2 See küng. Does Ged Exist?. p. 520.

3"Hegel," says Küng, "attracted me from the years when I was studying philosophy" in Rome, I.e.. 1948-51 ("Interview, "p. 155). During his years of study in Rome, Father wilhelm klein, Küng's spiritual director at the German College, called his attention to Hegel and Barth (see "Interview," p. 135; cf. Kiwiet, p. 18). Küng's work on Hegel's Christology and philosophy has been consider. able. He reveals that it had originally been intended for "a doctorate in philosophy at the Sorbonne and then as a thesis for tite theological Habilitation" at the University of Münster, in 1959. Having been "tucked away in a drawer" for almost ten years it finally came to light, after four revisions, in his book Menschwerdung Gottes published in 1970 (see "Interview," p. 154).

${ }^{4}$ As pointed out earlier, both Küng's dissertation for his Licentiate in Theology (conferred by the Pontifical Gregorian University, Rome, 1955) and his doctoral dissertation (Catholic Institute of Paris, 1957) were devoted to Barth's theology (see above, p. 118, n. 1; and F. 119, n. 4).

5 Küng, Does God Exist?, p. 514. 
found together and reconciled," and where the Absolute is understood as "the unity of the infinite with the firite"l--with its characteristic tendency to synthesis was at odds with the neo-scholastic Cathelic theolugy, in particular with its two-tier conception of the universe. Hegellan speculation may have helped küng to develop a critical view of this dimension of his church's theology.

\section{Some Important Shifes in Küng's Theology}

Apart from the question of the pastoral and theological concerns which constitute the starting point of Kung's theology, the fact staids that is riews, as migit be expected of any theologian, have undergone an evolution ${ }^{2}$. In küng's sase, howe:er, this evolution means at times a radical change. ${ }^{3}$ Three important shifts of Küng's theological position may be noted here.

I Ibid., p. 141.

2In 1978, Küng acknowledged the fact that some changes in his theology had occurred at specific moments of his career (see "Interview," pp. 129-30). He pointed out the places of his schooling as related to decisive turning points in his theological development, nrmely, the gymasium in Lucerne, the Gregorian University in Rome, the Institut Catholique and the Sorbonne in Paris, and the University of Tubingen. In my opinion, the major turning point, at least from the perspective of the issue of orthodoxy-heresy, is to be identified with his joining the University of Tübingen.

${ }^{3}$ This fact entails two observations: (1) Considering that Kung's theology is still in the making, any analysis of his position can only be temporarily valid. One should remain open to further possible developments and shifts in his theology. (2) In quoting from Küng's published books and articles, one must carefully nutice to which stage of his theological evolution those thoughts belong. This is necessary in order to avoid drawing unwarranted conclusions. 
From intra-church themes to general ones

The first shift, already hinted at, has to do with a change of emphasis from intra-church issues into broader themes of generai interest, in which küng tries to maintain a Christian perspective. This change took place during the seventies. Küng himself thus wrote in 1978. 1 In fact, three of the books written by küng after his dismissal as a Catholic professor in December 1979, reflect a non-strictly theological, even non-merely Christian outlook. These are: Art and the Question of Meaning, ${ }^{2}$ Ezernal Life?, ${ }^{3}$ and Christianity and the World Religions. ${ }^{4}$

In Etemal Life? küng plainly states that what one can read about eschatology in "theological textbooks" often seemed to him less important for answering the various questions about eternal life than what "poets and philosophers, doctors and scientists, have

In I have increasingly turned from internal Church problems to devote myself to the problems of contemporary men and women, of contemporary science and scholarship, and of contemporary society. . . What honestly fascinates me is everything that is of significance for us theologians today in astrophysics, in atomic theory, in microblology, in psychoanalysis, in philosophy and sclentific theory--but also in literature, art, and music" (see "Interview," PP. 182-83). This self-analysis is confirmed by küng in his recent article, "On Being a Christian Theologian," The Critic (Summer 1987) $13-15$.

2Originally published as Kunst und Sinnfrage (Zurich and Cologne: Benziger Verlag. 1980). It was translated into English by Edward Quinn (New York: Crossroad, 1981).

${ }^{3}$ Translation by Edward Quinn, of Ewiges Leben? (Munich: R. Piper \& Co. Verlag, 1982). The book is based on a nine-day course of lectures offered at Tübingen in the summer term of 1981.

${ }^{4}$ Published by Piper Verlag of Munich as Christentum und Weltreligionen in 1985 . 
written--positively or negatively--about it."l In this book, as well as in On Being a Christian and Does God Exist?, he attempts to answer the urgent questions or our contemporaries "on the basis of present-day theological studies, ${ }^{2}$ which means, at its core, to listen to historical-critical exegetical findings.

In harmony with this approach, Kung lists among his "ten guiding principles for contemporary theology" the necessity not only to promote but actually practice "an interdisciplinary approach." 3 What is needed, he thinks, is a "critical dialogue" between theology and philosophy, on the one hand, as well as between theology and natural science on the othar. ${ }^{4}$ In addition, adds küng,

We must avoid a confessionalistic ghetto mentality. Instead we should espouse an ecumenical vision that takes into consideration the world religions as well as contemporary ideologies: as much tolerance as possible toward those things outside the Church, toward the religious in general, and the human in general, and the development of that which is specifically Christian belong togcther! ${ }^{5}$

\section{A change in his view of the Scriptures}

The second important shift in Küng's theology has to do with his view of Scriptures. Since he regards them as the norma

$1_{\text {Eternal Life?, p. xiv. }}$

2Ibid., pp. xiv-xv.

${ }^{3}$ See Küng, "Toward a New Consensus in Catholic (and ecumenical) Theology" [hereafter referred to as "New Consensus"], in Swidler, Consensus in Theology?, p. 13.

${ }^{4}$ Ibid., pp. $13-14$.

5Ibid., p. 14. 
normans, 1 the "primary norm" for Christian theology, ${ }^{2}$ the relevance of this matter for his concept of orthodoxy-heresy can hardly be over-emphasized.

Before being appointed to succeed Heinrich Fries as Professor of Fundamental Theology at the University of Tübingen in 1960, Küng advocated the traditional Roman Catholic view on Sacred Scriptures. Thus, in his book Justification he refers to them as the Word of God. ${ }^{3}$ Furthermore, he affirms that, in contrast with the documents of tradition which only contain the Word of God, the Scriptures are "the unmediated and wanifest word of God in every sentence." 4 As God's Word, Sacred Scriptures are "a source free of error, valid for all times and places."5 In the context of his discussion on whether it was the intention of the Council of Trent to teach that divine tradition is an inspired source of revelation In addition to and of the same nature as the Scriptures, he states (quoting Johannes Baptist Cardinal Franzelin) ${ }^{6}$ that the Scriptures alone are inspired. 7

${ }^{1}$ See, for instance. The Church, p. 36; "New Consensus," p. 17.

2 Justification, pp. 113, 180 passim.

3 Justification, p. ii3.

${ }^{4}$ Ibid., p. 116.

5 Ibid., p. 112 .

${ }^{6}$ Iractatus de divina Iraditione et Scriptura, 2d ed. (Rome: n.p., 1875), p. 364 .

7 Justification, p. 116. 
The Importance of the University of Tübingen for Küng's change of perspective in much of his theological task can hardly be overstated. It was there, since 1962, that küng occupied himself intensively for the first time with the historical-critical methods of exegesis. 1 His former theological training provided him little understanding "of what was involved in a radical critical exegesis," states Küng, so that his discussions with the Protestant theologians of Tübingen--Ernst Kăsemann and Hermann Diem--gave him the opportunity to get better acquainted with this school. ${ }^{2}$ He eventually accepted it as providing indispensable tools to do exegests. ${ }^{3}$

Once at Tübingen, his study of the "historical and critical principles" of biblical exegesis ${ }^{4}$ produced a radical shift from his "pre-critical" statements about the Scriptures. 5 As Walter Kasper puts it, "In the Church and on Beine a Christian Küng no longer

Isee "Interview," p. 156.

2Ibid., pp. 157-58.

3so, writing absut his questioning the "high" Christology, or Christology "from above," which he had advocated previously in h's career, Küng says that "this Christology lacked adequate foundation in the historico-critical examination of the New Testament sources" ("On Being a Christian Theologian," p. 13). Among his "ten guiding principles for contemporary theology," Küng includes this one: "Theology must everywhere be oriented toward the biblical findings analyzed by historical-critical analysis" ("New Consensus," p. 14). He observes that the New Testament is the original witness to the historical Christ which "today we must interpret historically-critically" (ibid., p. 17).

\footnotetext{
4 "Interview," p. 156.

${ }^{5}$ See LaCugna, Methodology of Küng, p. 71.
} 
140

equates the Word of God with the Scriptures." 1 Though he still attributes to them an unique originality which makes of them ${ }^{n}$ the nozma nermans of the Church's tradition," the Scriptures are now described as "human words," the original "testimony of God's word of revelation." 2 Though "theologically normative for the believing. Church," they also have a historical and literary character. They are the testimony of "real men in all their humanity, historicity. and fallibility," whose language is frequently "hesitant" and whose concepts are "often imprecise." 3 Thus, Instead of regarding them as "a source free from error," kung now states that "errors of the most varled kind cannot a priori be excluded" from the text of the Scriptures. ${ }^{4}$

He also advocates, consequenty, a concept of inspiration which discards inerrancy. Inspiration should not be seen-like in the "early Hellenistic Church" and in the much later "Lutheran and Reformed orthodoxy"--as consisting in a mechanical dictation of the divine Spirit, 5 but as "the whole course of the origin, collecting, and trañmission of the word," as well as its acceptance in faith

1Walter Kasper, "Christsein ohne Tradition?," in Hans Urs von Balthasar et al., Diskussion über Hans Küngs "Christ sein" (Mainz: Matthias-Grünewald Verlag, 1976), Pp. 26, 29-30.

${ }^{2}$ The church, p. 36 ; cf. Infallible?, p. 215. Kung affirms that "Scripture is not revelation: it attests revelation," (ibid., p. 217; emphasis in the original).

3 The Church, p. 37.

Infallible?, p. 215. CE. tbid., p. 210 ; Christian, p. 464.

${ }^{5}$ Christian, p. 464. 
and proclamation. 1 When the writers of thr: NT manifest that they are aware of being moved by the Holy Spirit, Küng observes that they are simply stating their presupposition that "any reception or proclamation of the gospel occurs from the very beginning 'through the Holy Spirit' ( 1 Pet $1: 12$; cf. 1 Cor $7: 40$ )." 2

\section{A change of theological perspective}

In addition to both his more recent concentration on themes of general interest and the change in kung's view of the Scriptures, a third shift occurred in his theology, namely, a change of perspective in his theological reflection. This shift is particularly manifest in his Ecclesiology and Christology.

As for the doctrine of Christ, for instance, it must be noted that in his early study of Georg W. F. Hegel's philosophy and theology, Küng showed interest precisely in that philosopher's understanding of Christology as God becoming man, ar. finsight which helped to support the Christology "from above" 3 that our theologian advocated in his early years and which is assumed in his book Justification. Later, after joining the University of Tubingen and occupying himself with historical-critical exegesis, Küng changed his course of thinking, concluding that it was "from below"4 that

Infallible?, p. 216 ; cf. Christian, p. 465.

2 Ibid.

$3_{\text {By this expression Küng means a Christology which }}$ presupposes the divine preexistence of Jesus Christ, thus emphasizing his incarnation.

${ }^{4} \mathrm{~A}$ Christology "from below" stresses the human nature of Christ by looking at him from the perspective of the apostles and 
contemporary people "could more convincingly strive to attain and could reach the statements of a 'high' Christology."l

It was Küng's homiletical use of "The Gospel according to Mark," 2 he says, that helped him to realize that Jesus is experienced in a much fresher way if one does not just take for granted that he is the Son of God who came down from heaven (the approach "from above"), but, learns to develop faith in him from the perspective of the disciples who saw Jesus at first as the Rabti from Nazareth in whom they recognized the Son of God (the Christology "from below").

In a similar vein--now regarding ecclesiology--in his volume The Church. Küng proposes as the most suitable an understanding of the church "from below". He in fact contends that

The "essence" of the Church is not a matter of metaphysical stasis, but exists only in constantly changing historical "forms.". . . Rather than talking about an ideal Church situated in the abstract celestlal spheres of theological theory, we shall consider the real Church as it exists in our world, and in human history. The New Testament itself. . . starts with the Church as reality, and reflection upon it comes later. The real Church $\frac{i s}{3}$ first and foremost a happening, a fact, an historical event. ${ }^{3}$

the disciples who knew him first as the Rabbl from Nazareth and in whom they eventually recognized, by faith, the Son of God.

${ }^{I}$ see "Interview," pp. 155-56. Küng claims that even Professor Joseph Ratzinger, currently Prefect of the Sacred Congregation for the Doctrine of the Faith and his then colleague at Tübingen, endorsed this view (ibid., p. 156).

2With the help of Eduard Schweizer's commentary The Good News According to Mark, trans. Donald H. Madvig (Richmond, Virginia: John Knox Press, 1970). See "Interview," p. 157.

${ }^{3}$ The Ch:urch, p. 23; emphasis in the original. 
In connection with this shift in Küng's theological perspective, Karl Barth wrote an extensive letter to küng on October 12 , 1968, I asking him: "Where in this book of yours is the author of the book on justification?"2 Barth was referring to Küng's Iruthfulness: The Future of the Church, which he frankly criticized stating that it had produced in him "a certain deep-seated uneasiness" 3 due in part to küng's new way of thinking "from below upward." 4 Thus Barth, too, who had sympathetically written "A Letter to the Author" to be published in Küng's volume Justification ${ }^{5}$ noticed a radical shift in our theologian's writings.

The motivations of Küng's shifts

The fact may not have passed unnoticed that the referred shifts in Küng's theology were mainly prompted by one of his main pastoral and theological concerns, namely, to make the gospel of Jesus Christ--and therefore the proclamation of the church--relevant and credible for modern-minded men and women. What troubles him is not simply the plight of modern human beings. Nor is he merely

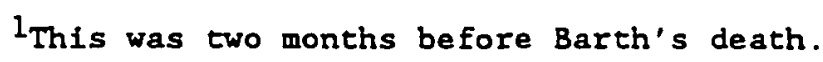

2 Karl Barth--Letters $1301-1968$, ed. Jürgen Fangmeier and Hinrich Stoevesandt, trans. and ed. Geoffrey W. Bromiley (Grand Rapids, Michigan: William B. Eerdmans, 1981), p. 319.

I Ibid., p. 317.

${ }^{4}$ Barth refers as well to the "painful impression of legalism" that the work as a whole had left on him (ibid.; emphasis in the original).

5.ustification, pp. xxxix-xlii. 
desirous to sound "modern." As his third bookl shows, Küng is clearly wresting with the problem of the credibility of the church's message in the modern world. Referring to some of the Roman Catholic teachings (in particular the Marian dogmas and papal infallibility) as well as to the persecution of Protestants in some areas of the world, to the condemnation of scientific theories, and even to "the superstition and miracle-fever and apparition-mania in so many or the faithful, ${ }^{2}$ küng notes that in the eyes of those outside it, "the church is smothered by all these things." Obviously, the latter do not constitute a help "that the world may belleve" but a hindrance. To a great extent, they make the church incredible to the world. ${ }^{3}$ kung contends that the church ought to recognize these and other errors. When the church does not conceal its mistakes, but constructively comes to terms with them, it is both truthful and credible, remarks he. 4

What is behind Kung's shifts in his theological development as well as behind his pastoral and theological concerns is his "passion for truth." 5 His basic attitude toward truth is reflected in his quotation of the principle advocated by Pope Gregory the

$1_{\text {Kung. That the World May Believe. This book, written while }}$ Küng was already teaching at Tübingen, has a preface signed in May 1962 (see May Belleve, p. 10).

2Ibid., PP. 27-30.

3 Ibid., p. 30.

${ }^{4}$ Truthfulness, p. 141.

${ }^{5}$ This is the title of a book on Küng's theology written by Robert Nowel1, A Passion for Truth: Hans Küng and His Theology (New York: Crossroad, 1981). 
Great: "If scandal is taken at the truth, then it is better to allow scandal to arise than to abandon the truth." 1

Furthermore, what really disturbs the Swiss theologian is the "manipulation of truth" which he regards as aimed at maintaining "the doctrinal system" of the institutional church. He is uneasy at the fact that on occasions "truth is put at the disposal of the system ard politically managed." 2 Here, the way in which küng differentiates between "truth" and the officially enforced "doctrinal system" (orthodoxy) is evident. The type of orthodoxy that he advocates is far from a petrified doctrinal system. In his view, all too frequently an officially approved system of doctrines is used by those who have "every instrument of power" in the church to condemn their opponents "out of hand, without serious argument" and with the sole purpose of "domination." 3 For him, correct belief (orthodoxy) is to be identified with "the basic faith of the ecclesia," the true message of salvation, the original gospel. 4 The manipulation of truth which characterized Catholicism in the past, Küng notes,

is rampant above all in the totalitarian systems, where the ruling party "possesses" all truth. . . . Free discussion is suspect, dissenters are morally disqualified; within the

lQuoted in Küng, The Council, p. 45.

${ }^{2}$ Iruthfulness, p. 141.

${ }^{3}$ Ibid., pp. $141-42$.

${ }^{4}$ See, for instance, Küng, The Church, p. 315; idem, Maintained, pp. $39-46$. 
dominant machinery of bureaucracy truth is the result of political struggle. 1

Such statements have a significant bearing not only on Küng's concept of truth but on his view on the principle of religious authority as well, two issues which form part of the orthodoxy-heresy structure and which I shall appraise later in this dissertation. 2

\section{Küng's Hermeneutical Principles}

In addition to both the pastoral concerns which constitute Küng's theological starting point and the important shifts in his theology which I have just described, his hermeneutical principles must be counted among the most important traits which define him as a theologian.

Küng's hermeneutical principles are conveniently summarized in an essay he wrote as a contribution to Leonard Swidler's volume Consensus in Theology? in 1979. 3 There Küng deals with the question whether the theological methods employed by him in on Being a Christian and Does God Fxist?, snd by Edward Schillebeeckx in his books on Jesus ${ }^{4}$ might provide the basis for a new consensus on how

$1_{\text {Iruthfulness, }}$ p. 142.

2For a discussion of Kün's attitude toward religious authority, see below, pp. 157ff. As for my analysis of his concept of truth, see below, Pp. 274-315.

${ }^{3}$ See Swidler, Consensus, pp. iii-iv. The article by Küng is "New Consensus," in ibid., pp. 1-17.

${ }^{4}$ Edward Schillebeeckx, Jesus: An Experiment in Christology, trans. Hubert Hoskins (London: Collins, 1979). The original Dutch edition of this book appeared in Holland in 1974. A second book by the same author published in Holland in 1977 was translated into 
to do contemporary theology. Outlining both his own theological method and the one he perceives as Schillebeeckx's, Kunng concludes that a fundamental consensus exists between them. My intention at this point is merely to describe the most salient aspects of the hermeneutical principles of küng, particularly as he expresses them in his "ten guiding principles for contemporary theology." I

Two elements--tc which Küng at times refers as two "poles," "sources," or "criteria"-are of paramount importance among his hermeneutical principles. He describes them in the context of his concern for dealing "effectively with the contemporary problems of humanity, the Church, and society. ${ }^{2}$ Writes küng:

In our current decade it has become increasingly evident that the only theology (primarily systematic and especially dogmatic theology) that could survive the future would be one that was daringly able to blend two vital elements in a nontradtional and highly convincing manner. These two elements are a "return to the sources" and a "venturing forth on to uncharted waters," or to put the matter less poetically, a theology of Christian orfirins and center enunciated within the hortion of the contemporary world. ${ }^{3}$

It seems obvious that "the 'two poles' of theology"4 as Küng perceives them--namely, "God's revelational address in the history of Israel and the history of Jesus," and "our own human world of

English in 1980: Christ: The Christian Expertence in the Modern World, trans. John Bowden (London: SCM Press, 1980).

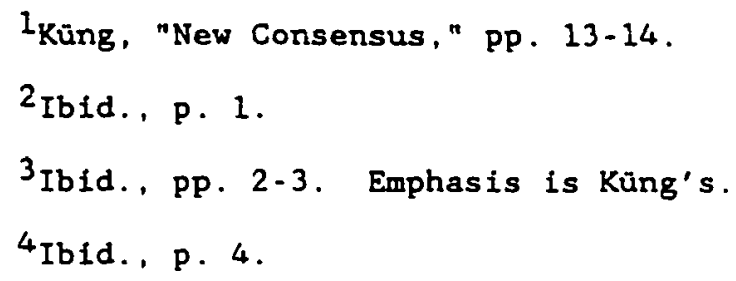


148

experience"1.-respond to his main pastoral concerns described earlier. Indeed, a return to the revealed sources of Christian doctrine ${ }^{2}$ serves his purpose of bullding an ecumenical Christianity upon the cornerstone of the original gospel of Jesus Christ. On the other hand. the venturing forth on to a theological dimension not marked by traditioi but by the horizon of the contemporary world speaks of Kung's concern for communicating the gospel to modern man In terms that the latter may accept. ${ }^{3}$

In thfs context, Küng holds that dogmas "will not be equated with the Christian message."4 Theology should not "defend an 'ecclesiastical' system but strive for the truth without compromise in intense scholarly fashion." 5 küng does not think it is legitimate, when dogmas become questionable, to try to make them "more palatable to contemporary humanity by the use of transcendental or other speculative methodologies."6 What is necessary is to deal

IIbid., pp. 5, 11.

2Küng's principle number seven states: "The criterion determining all other criteria of Christian theology can never again be some ecclesiastical or theological sradition or institution, but only the Gospel, the original Christian message itself. Thus theology must everywhere be oriented toward the biblical findings analyzed by historical-critical analysis" ("New Consensus," p. 14).

3nThe Gospel should not be proclaimed in biblical archaisms nor in Hellenistic scholastic dogmatisms nor in fashionable philosophic-theological jargon. Rather, it should be expressed in the commonly understood language of contemporary humanity and we should not shy away from any effort in this direction," reads Küng's principle number eight (Ibid.).

4 Ibid., p. 3.

5This is Küng's principle number two (see ibid., p. 13).

6Ibid., p. 3. About the same time as his essay "New 
with the content of Christian faith within the horizon of the total experience of humanity as a whole, and to express the Christian message in such a manner that it may be able to solve the problems and answer the questions of contemporary men and women. For this purpose, an itiserdisciplinary dialog between theology, philosophy, and the natural sciences is deemed indispensable by Küng. 1

However, the horizon of human experience and the collaboration of modern phllosophy and sciences, even though important, is not, in Küng's view, the only "source, pole, and criterion" for contemporary theology. The other pole, of basic importance, is constituted by the original gospel of Jesus Christ and the experience of faith of both the people of Israel and the first disciples of Christ. ${ }^{2}$ Contemporary theology is to be done in a

Consensus," küng wrote that a theology called to address the concerns of the modern mind cannot be "a theology which is part of the 'ajstem.' justifying the Church's dogmatic system in every case" (Maintained, p. 42). Since the Roman Catholic Church claims that the dogmatic definitions of the Magisterium "can never have been false and therefore may not be sorrected under any circumstances, only two possibilities remain," notes Küng: "Either simply to repeat them and support them with any quotations from scripture and Tradition that can be found (this is how positive neoscholastic theology works) or to 'interpret' them speculatively and try to make it possible for them to be assimilated by the modern mind (this is how speculative neoscholastic theology works)" (Maintained, pp. 4243). Küng remarks that in the latter case, interpretation is ususlly turned into contradiction (ibid., p. 43).

13-14.

${ }^{1}$ See his principles four and five in "New Consensus," Pp.

2Ibid., pp. 5-11. Elsewhere kung notes that "unlike the historian of religion, the theologian works within the limits of the Church's faith and presupposes it, but at the same time is expected to study it in a critically scientific spirtt." This is difficult, holds he, "but not impossible" (Maintained, p. 42). 
dialectical way, Involving these two sources, poles, and criteria. 1 This means that contemporary theology is bound to deal with the tension existing between history and faith. ${ }^{2}$ This tension is vividly at work in the case of one's belief in Jesus of Nazareth as the Christ. The recognition of Jesus as the Messiah appointed by God "always remains a venture of faith and trust or a metanoia," remarks Kung. ${ }^{3}$ Historical-critical research into the life of Jesus, on the other side, "neither desires nor has the capacity to prove that the man Jesus of Nazareth is in reality the Christ of God." Nevertheless, "we must be able to identify the Christ of faith as the Jesus of history." Historical-critical research can aid us, thinks kür.g, in assuring that "the Christ in whom we believe is really the man Jesus of Nazareth and not some other person or perhaps no one at all." This is in his view most important since one's belief in Christ "can all too easily be distorted into a superstitious attachment to an imaginary Christ or to a mere sign or symbol. 4

Besides Christological issues, another fllustration in the dogmatic fleld of Kung's dealing with the tension hetween historical

\footnotetext{
1 new Consensus, " pp. $9-17$.

${ }^{2}$ For a relevant treatment of this dialectical tension in Küng, particularly in his Christology, see James Mattison King, "Hans Küng's Concept of Authority" (Ph.D. dissercation, Southern Baptist Theological Seminary, 1981), pp. 122-79.

$3^{3}$ New Consensus," p. 7.

${ }^{4}$ For this and the preceding quotations, see ibld.
} 
thinking ${ }^{1}$ and faith ${ }^{2}$ is his argument for the existence of God. In his volume Does God Exist? he holds that "both denial and affirmation of God are possible."3 "Atheism cannot be eliminated rationally," remarks Küng, nor can it be rationally established. "It is undemonstrable." 4 Consequently, belief in God's existence is neither rationally or historically demonstrable nor can it be rationally or historically disproved. The affirmation of God's existence implies a "radical fundamental trust." 5 It is a matter of personal choice, an experiential "trusting commitment to an ultimate ground" of reality; it is "faith in God." 6

It may be concluded that in what touches upon the essentials of Christian faith, Küng's rationale for his belief in them seems to be primarily his personal faith.

\footnotetext{
$1_{\text {At }}$ the core of the modern historical way of thinking, at least in Kung's understanding, is the awareness about "the fundamental difference between the biblical and the modern understanding of reallty" (see Küng, Does God Exist?, pp. 650 and passim). In what has to do with miracles, for instance, Küng s=eerts that historica? and licerary criticisms of the biblical accounts have shown that "the miracle stories are not meant to be stralghtforward records of historical events." Some of them have the "character of legend" (1bid., pp. 650-51).

2 Even though "fundamental trust" can be called "faith." they should be distinguished, remarks küng. The latter term is reserved in his usage for "faith in the strict sense: religious faith, faith in God or the Divine, and, in a special way, of raith in the God of the Biblen (Dnes God Exist?, pp. $473 \mathrm{ff}$ ). On the other hand, fundamental trust is described as the primordial attitude of "saying yes" to reality over against nihilism (ibid., pp. 442-77).

${ }^{3}$ Does God Exist?, p. 568.

${ }^{4}$ Ibid., pp. 568-69.

5 Ibid., p. 572 .

${ }^{6}$ Ibid., p. 570.
} 
We can also conclude that the methodological use of dialectical tensions is indeed one of the most characteristic features of küng's way of doing theology. It is also an important reason for the difficulty in understanding his at times apparently contradictory statements. The particular tension between the faith of the theologian and his "critically scientific spirit"l is to be seen at work as my analysis of Küng's views progresses. To such an analysis the following two chapters are devoted.

l Maintained, p. 42 . 
CHAPTER III

THE GRIIEKTIA AND NORMS OF CLASSICAL ORTHODOXY

The historical-theological analysis of the orthodoxy-heresy antithesis developed in chapter 1 makes it possible to enter into the description and analysis of Hans Kung's model of orthodoxy. heresy with spectfic loci in mind. These are the constitutive elements of the orthodoxy-heresy issue identified and described above.

Chapter 1 also provided some natural divisions into which the components of the orthodoxy-heresy structure can be sorted, thus suggesting a historical-systematic approach to our query. Eirst. two general principles were identified which appeared successively in the history of the church and theology. They are the principles of authority and of succession-tradition, in that order. The principle of authority, in turn, was expressed first in the revelational criterion of orthodoxy and later in the ecclesiastical criterton. The ecclesiastical criterion of orthodoxy is indeed the expression of both the principles of authority and of successiontradition. As for the revelational criterion, it took concrete form in two norms of orthodoxy: the teaching of the apostles and the NT Canon. The ecclesiastical criterion, for its part, found concrete expression in two additional norms of classical orthodoxy: the oral tradition of the apostolic churches and the pronouncements of the 153 
episcopal Magisterium. Within the context of the ecclesiastical criterion of Christian truth, two theological issues emerged during the Middle Ages as fundamental for the understanding of orthodoxy, namely, the unity and the infallibility of the church's doctrinal definitions.

The crisis brought forth by the Protestant Reformation made necessary the determination of a hermeneutical criterion capable of solving the impasse in which the Scriptures and the teaching authority of the church found themselves. A new hermeneutical criterion was offered to the theological community in the change of presuppositions or basic assumptions which emerged in the Western world from the eighteenth century on. This change brought forth a new world-view which challenged the classical and medieval transcendent, timeless, and static notion of ultimate reality and truth. In contrast with the two-tiers theory of the structure of reality prevalling until then, the dominant "Weltanschauung" of the post-Enlightenement period came to be historicism, 1.e., the dynamic and temporalistic conception of the world which tended to view all knowledge and all forms of experience in a context of historical change and development. The new historical consciousness involved a dynamic understanding of reality (i.e., a nori-static cntology) which, in turn, entails a relativistic epistemology. In this context, two major theological issues came to the forefront of the orthodoxy-heresy antithesis; they are the issues related to the truth and infallibility (or fallibillty) of propositions of faith, and those related to continuity and change in theology. 
The main purpose of this third chapter is to describe and analyze Küng's theological views regarding the norms of classical orthucuoxy which we have described in relation with the revelational and the ecclesiastical criteria of Christian doctrine, namely, the doctrine of the apostles, the Canon of the New Testament, the oral traditions of the church, and the pronouncements of the Magisterium. Küng's attitude toward the principle of authority, which I regard as the general ground for the definition of orthodoxy, as well as his position concerning the principle of tradition are also considered.

Even a mere glance at Küng's writings reveals the fact that he has addressed in several of his writings the elements constitutive of the orthodoxy-heresy structure mentioned earlier. In the first part of this chapter my analysis of Küng's views focuses, first, on some of his most explicit statements regarding the principle of authortty. I then proceed to a study of his views on the norms related to the revelational criterion of orthodoxy, i.e.. the teachings of the apostles and the Canon of the New Testament.

The second part of this chapter is devoted to the description and analysis of Hans Küng's views on the ecclesiastical criterion of Christian doctrine as expressed in the oral traditions and the pronouncements of the Magisterium as concrete norms of orthodoxy. The principle of succession-tradition, and the issue of the untty of the church's doctrine are also examined. 


\section{Part One: On the Principles and Norms Related to the Revelational Criterion of Orthodoxy-Heresy}

The historical-theological analysis of the development of classical orthodoxy in chapter 1 showed that the fundamental criterion of Christian truth of the early church resided in the believers' recognition that their beliefs were based on the authority of divine revelation. From its inception, Christianity was rooted in its awareness of being a religion of revelation rather than a system of philosophical speculation or a scientific theory of the world. Thus, the first criterion of classical orthodoxy which we identified among the constitutive elements of the orthodoxyheresy structure is the revelational criterion, in which the princlple of authurity was expressed.

The issue of religlous authority has come to the foreground of theological concern in recent times. It might be affirmed that the current conflict regarding orthodoxy-heresy is intimately related to a crisis of authority which is as typical of the secular world as of the Christian churches. In the words of Clyde L. Manschreck, professor at the Chicago Theological Seminary at the time of this writing: "Today we live in a world in which there is no generally accepted authiolity." ie holds that

Epistemologically, we have arrived at a point where right and wrong, reality and unreality, truth and untruth are highly ambiguous. We see this expressed in theories of relativity, indeterminancy, positivism versus idealism, religious dogmas versus existential demands, etc. ${ }^{1}$

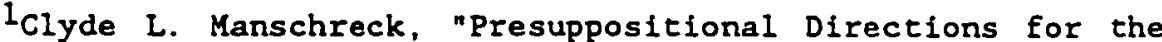
Problem of Authority," RevExp 75 (1978):181. 


\section{Küng's Understanding of the Principle of Authority}

In the framework of this contemporary attitude toward authority, my intention is to analyze, first, Küng's position regarding religious authority in general. This being clarified, we then discuss his views on revelation, the doctrinal authority of the apostles, and the normativity of the Scriptures.

James M. King observes that religious authority is no side issue for Hans Kung, but indeed "the central theme of the majorfty of his writings up to this point." ${ }^{1}$ Though it is not easy to define "the central thcme" of king's theology, partioularly from a later perspective, ${ }^{2}$ we can only agree with king as to the importance of the issue of religious authortty (both doctrinal and ecclesiastical) in the Swiss theologian's literary production. This is true especlally during his first decade of writing, when he was particularly concerned with ecclesiological issues.

The critique of the Roman Catholic model of authority

In the late 1950's and early 1960's, in the first stage of his theological development, ${ }^{3}$ Küng concentrated on ecclesiological

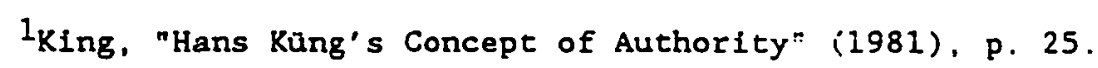

${ }^{2}$ This writing is being done at the end of 1987 , some six years after King's dissertation.

In a recently published retrospective look at his own theological development, Küng distinguishes three periods which he describes as "concentric circles" spreading out of his central Christian conviction rooted in the gospels. The first such period corresponds to the decade of the sixties, when his theological work was mostly confined to questions of ecclesiology. See Küng, "On Being a Christian Tt.sologian," The Crifle 41 (Summer 1987):12.
} 
matters in the historical context of the ecumenical awakening of the Roman Catholic Church. At that time küng dealt with the principle of religious authority, regarded in my analysis as the fundamental ground undergirding the traditional criteria and norms of orthodoxy. Though he has criticized the Roman Catholic model of authority in strong terms, 1 Küng should not be seen as an anarchist asking for the eradication of authority in the church. On the contrary, he wrote explicitly to that effec:: "We are not speaking against authorfty in the Church, but for it." 2 Yet, Küng was convinced that "we urgently need today a renewed authority, aware in a new way of what is involved in the original Christian message and required at the present time." ${ }^{3}$ Indeed, central to Küng's ecclesiology are his constant advocacy for renewal in the Catholic Church's theology and life, and his ofposition to anarchism. These two concerns stand in dialectical tension, a tenstinn not unrelated to the issue of continuity and change in the theology of the church. They also manifest the two chief pastoral preoccupations which we have identified as Kung's theological starting point: (1) his concern for the unity of Christianity around its original message and (2) his concern for giving a relevant Christian ariswer to the

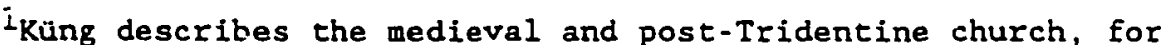
instance, as "scholastic, legalistic, hierarchical, centralistic, sacramentalistic, traditionalistic, exclusive and often superstitious" (Trutheulness, PP. 1-2).

2 Küng, Truthfulness, p. 7.

'Ibid; emphasis is Küng's. The original Christian message is, for him, both the norm of all renewal in the church and the "common denominator" for the ecumenical dialogue. 
needs of modern man, in other words, to proclaim the gospel in a way meaningful to our contemporaries.

Küng's leading pastoral concerns compelled him to confront the Roman Catholic model of authority at two different levels.

In the first place, pointing out that the church's way of exercising religious authority constituted the number one stumbling block to Christian unity, 1 he proposed an attitude of the church's leadership which would uncover its servant nature rather than an authorftarian one. ${ }^{2}$ Though recognizing the foundational nature of authority in the church (particularly in the Roman Catholic Church), Küng insisted on his concept of authorlty as a "service" to the community of believers, a notion which he sees rooted in the New Testament. He holds that "authority is only legitimate when it is based on service and not on power." 3 If we want to speak in a precise theological fashion, he noted, we should speak about "Church ministry" rather than about "Church office." 4 Considering it to be his duty to work tirelessly to eliminate the obstacles which in his

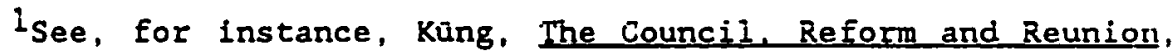
trans. Cec1ly Hastings (New York: Sheed and Ward, 1961), pp. 128-29 [quoted hereafter as The Council]. The British edition of this book (London: Sheed and Ward, 1961) carries the shorter title the Council ani Reunion. See also Küng. The Council in riction: Theological Reflections on the Second Vatican Council, trans. Cecily Hastings (New York: Sheed and Ward, 1963), p. 197 [hereafter referred to as Counctl in Action].

2 See, for instance, Küng, why Priests? A Proposal for a New Church Ministry, trans. Robert C. Collins (Garden City, New York: Doubleday, 1972), Pp. 39-40. German original, Wozu Priester? Eine Hilfe (Zurich, Einsiedeln, and Cologne: Benziger Verlag, 1971).

${ }^{3}$ Küng, Why Prlests?, Pp. 39-40; cf. The Church, pp. 495-611.

${ }^{4}$ Why Priests?, pp. $39-40$. 
view prevent the reunion of Christians, Küng voliced his disagreement with the methods, proceedings, and practices of the Roman Catholic hierarchy, which he finds authoritarian, and advocated in his first books $^{1}$ an organizational structure of the church adapted to the accomplishment of its mission in an evangelical and servant manner. ${ }^{2}$ In the second place, addressing an issue which stands closer to the orthodoxy-heresy antithesis, küng confronted the Catholic modnl of authority at the level of the "teaching authority" of the church. Revealing again his pastoral concern, he noted that the church's teaching authority remains the number one stumbling bloct. to unity. ${ }^{3}$ küng advocates the duty of theologians to assist the Magisterium in its teaching activity through the discernment, by scholarly means of modern research, of whether the church speaks

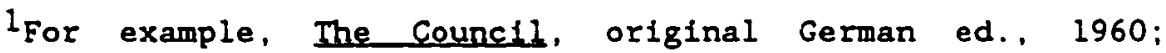
Structures of the Church, trans. Salvator Attanasio (New York, Edinburgh., and Toronto: Thomas Nelson \& Sons, 1964) (hereafter referred to as Structures], original German ed., 1962; and Counc:1 In Aetion, original German ed, 1963.

${ }^{2}$ Consider, for instance, the following statement: "The chief difficulty in the way of reunion lies in the two different concepts of the Church, and especially of the concrete organizational scructure of the Church. . . . Ultimately, all questions about the concrete organizational structure of the Church are crystallized in the question of ecclesiastical office, . . The question has to be asked about every level of ecclesiastical office (the Petrine office, bishops, priests, deacons): what is their origin and nature? Whence do they receive their powers? What meaning and authority do they have in the domain of doctrine and dogma, of liturgy, of furisdiction?" (Küng. The Council, pp. 128-29; emphasis his).

${ }^{3 n}$ The tremendous difficulties blocking the way to a reunion of separated Christians seem nowhere so insuperable as in the Cathnific doctrine of the infallibility of the Church, of ecumenical councils and especially of the Pope. It seems impossible that Lutherans, Calvinists, Anglicans, Old Catholics and Orthodox should ever be able to accept an infallibility of this sort" (Küng: Counc1l in Action, p. 197). 
161

correctly of God.1 Küng's decision in favor of "scientific theologyn2 showed up here, a decision which he wanted to harmonize with his regard for the principle of authority: Even though in the church "theology cannot take the place of authority," neither can the latter be "a substitute for theology," 3 remarked he.

Küng's views on the role of theology in the understanding and definition of Christian truth were at odds with the official position of the Catholic Church and with the views of several of his colleagues ${ }^{4}$ and superiors regarding religious authority, specifically in doctrinal matters. Whfle, for instance, Vatican II states that the teaching of the bishops in communion with the Roman Pontiff alone is authoritative for the Catholic believer, ${ }^{5}$ Küng holds that

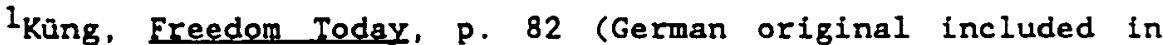
Küng's Theologe und Kirche (1964]).

2 Küng, "On Being a Christian Theologian," p. 12.

${ }^{3}$ Ereedom Today, p. 82.

"When the Vatican announced the withdrawal of Küng's missto canonica on December 18,1979, the twelve professors of the Catholic Faculty of Tneology at the University of Tubingen unanimously expressed their support of Küng, pointing out the danger that action involved for the freedom of theological research. On February 5 , 1980, however, seven of thase eleven colleagues issued a declaration maintalning that any professor without a canonical mission should not remain on a Roman Catholic faculty. They felt that their support of Küng could not go beyond this point without putting them in confrontation with the church's authority (see Norbert Greinacher and Herbert Haag, eds., Der Fall Küng: Eine Dokumentation [Munich: Piper Verlag, 1980], PP. 235-44; see also John J. Carey, "Hans Küng and Tübingen: Compromise and Aftermath," ChrCent 97 [1980]:791-96).

${ }^{5}$ In the Dogpatic Constitution on the Church (Lumen gentium), art. 25 (see Abbott, Docs, of Vatican II, Pp. 47-48): "In matters of faith and morals, the bishops speak in the name of Christ and the faithful are to accept their teaching and adhere to it with a religious assent of soul." When Infallible? was questioned by the CDF in 1971, the Congregation observed that "the Constitution Lumen 
even though theology is not and should never be set against authority, 1 its criticism consisting in "measuring, testing, and correcting the way the Church speaks of God by the standard of the original message in Scripture, the Word of God itself," 2 is indispersable.

Though the issue of the relationship between the Magisterium and theologians is discussed below from a different perspective, ${ }^{3}$ one incident deserves mention at this point since it touches directly upon the matter of the teaching authority of the church and the role of theologians. On March 30, 1974, the Congregation for the Doctrine of the Faith (CDF) sent a letter to Kung in which it stated that no Catholic theologian could deny or doubt a dogma of faith ${ }^{4}$ defined by the Magisterium, not even in the name of

Gentium credits the authentic Magisterium to no one except the Blshops and the Supreme Pontiff (25)" (see Küng in Conflict, p. 65).

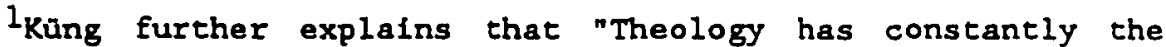
huge and difficult task of sifting, testing, examining, discerring. - . This discerning activity on the part of theology is not directed against authority; what it wants is to help authority in its task with the tools of theological science. Theology cannot take the place of authority in the Church; history proves this. But neither, on the other hand, can authority be a substitute for theology; history proves this, toon (Ereedom Today, p. 82).

2 Ibid.

${ }^{3}$ For my analysis of teaching authority in the context of Küng's view on the role of the Magisterium, see below, FP. 224-28.

4The notion of "dogma of faith" needs to be clearly understood. From a Roman Catholic perspective, dogma is a proposition which is the object of fides divina et catholica, i.e., one which the church explicitly propounds as revealed by God in such a way that its dental is condemned by the church as heresy. To be considered as dogma, a particular teaching must be clearly and explicitly defined as such by the Magisterium. In other words, a doctrine or belief held by the Catholic Church becomes "dogma" only 
theological freedom. 1 The Congregation informed küng that "In all your answers, the level of dogma seems to be totally nonexistent." Its letter pointedly observes that, for Küng, it all goes as if the doctrines he advocates "were all materlal for free theological discussion and did not touch upon any truth binding on a believing Catholic." 2

One should indeed keep in mind that, according to Catholic canon law, the "denial or doubt of a dogma of faith" is heresy. 3 The mention of heresy, however, is carefully avoided in the CDF's letter to küng. Instead, it states that "no Catholic theologian maintains that. . . the denial or doubting of a dogma of faith is

when tt is defined as such by papal or conciliar pronouncement (see K. Rahner, "Dogma--Theological Meaning," SY [1968], 2:96; cf. above, p. 81, n. 4. See also Denz, 1792; and CCL, 1983, can. 750; cf. CCL, 1963, can. 1323, \#1 and \#2). For a contrast between the Catholic and some Protestants' view on "dogma," see above, p. 93, n. 2 .

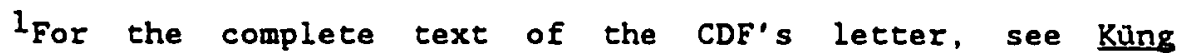
Dialogue, Pp. 78-84. On Pp. 82-83 the document states: "The Catholic theologian is certainly permitted to raise a question which touches on a truth of faith and then, to seek an explanation. But, even if he should not prompty find a rational justification of this truth, the Catholic theologian may not call in question the truth of faith itself or deny it. As long as he is a Catholic, no Catholic theologian maintains that, in the name of theology, the dental or the doubting of a dogma of falth is admissible. . . . You appeal to the freedom of theologians. However, the Congregation must remind you of the highest principle that presides over the exercise of this freedom: Both the teaching office and the theologians are in the service of revealed truth. Therefore, a believing Catholic is not free to deny a revealed truth in the name of theological freedom. Besides, theologians are accountable also to the ecclesial community and to ecclesial aurhority to which Christ himself has entrusted the task to teach and protect revealed truth (Lumen Gentium, 25; Abbott, 47-50; Def Verbum, 10; Abbott 117-118)." Emphasis is in the original.

2 See Küng Dialogue, p. 83.

${ }^{3}$ See CCL, 1963, can. 1325, \#2; cf. CCL, 1983, can. 751. 
164

admissible." I It must be observed also that the CDF's document points out that at the bottom of the controversy with the Swiss theologian is the issue of teaching authority. In this context, the Congregation reveals its concern by asking Küng "whether you still acknowledge that there is in the Church a doctrinal authority superior to your own." 2

Later the same year, the issue of authority and the role of theology were raised by Joseph Cardinal Höfner in a letter to küng dated December 23, 1974. The cardinal asked the very pertinent question, "Do the latest developments in theology and sociecy have the authority required to change the falth of the Church?"3 After enumerating several doctrines questioned by modern theology. Cardinal Hoffner underlined that a few theologians are nor merely formulating these doctrines differently, in fact "they say different things." He then asked a question cruclal for our dissertation: "Who decides who is right? The stronger arguments? Both sides claim to have the stronger arguments." Cardinal Hoffner ended his letter confronting kung directly with this statement: "The question I am asking is this: By what authority do you profess your opinions?"4 Küng's answer to this question came promptly in a letter he sent to the cardinal on January 10, 1975. In essence, he claims to

$1_{\text {I }}$ return to this matter later when further attention is given to the official Roman Catholic position on heresy (see below, pp. 237-38ff.).

${ }^{2}$ See Küng Dialogue, p. 83.

${ }^{3}$ See the text of this letter in Küng Dialogue, pp. 90-91.

${ }^{4}$ Ibid., p. 91. 
base his views on the Word of God, as the Magisterium ought to do, too. ${ }^{1}$ One can hardly wonder, therefore, that many, not only Roman Catholics, regarded Küng as a Protestant, even a "new Luther." 2 From a Roman Catholic perspective, John J. Hughes notes that "Küng's view of doctrinal authority in the Church appears to be, at bottom. that of countless Anglican and Protestant theologians." 3

It should be noted that kung does not deny the legitimacy or importance of the teaching authority of the church. What he wants to underline is that the Magisterfum's authority should remain, in practice as well as in its official statements, ${ }^{4}$ under the final authority of God's word.

Küng's critique of Catholic authorify in historical context: The early years up to 1962

We noticed earller ${ }^{5}$ that Küng's preoccupation with the reunion of the Christian churches was evident already in the years of his priestly formation. Likewise, the selection of the subject

$1_{\text {Wrote Küng: "You asked me: By what authority do you profess }}$ your opinions? My reply would have to be: By the authority of the Word of God which I, as a theologian, must serve. Whether I do this correctly, is, of course, an open question. However, the representatives of the Magistertum should in turn argue on the basis of the Word of God, instead of merely decreeing again what has been hancied down" (isee iüng Dlalogue, Pp 91-92).

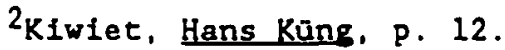
$(1980): 379$.

3John Jay Hughes, "Hans Küng and the Magisterium," IS 41

${ }^{4}$ Vatican II states that the Magisterium is not above the word of God but serves it.

${ }^{5}$ See above, pp. $122-23$. 
matter of his doctoral dissertation (his first published book, Justification (1957]), responds to the same concern. Two years later, while still engaged in pastoral work as assistant priest at the Hofkirche in Lucerne, Küng's concern was brought to the forefront in a sermon on the reunion of Christianity which he preached on Sunday, January 18--one week before Pope Join XXIII announced his intention to call a general council to prepare the way to the reunion of the separated Christians. 1 The following day, at the suggestion of Karl Barth, he lectured at the University of Basel on the Calvinist theme of the Ecclesta semper reformanda. ${ }^{2}$

During the years of preparation for the Second Vatican Council, ${ }^{3}$ Küng published two books, both relevant for the study of his concept of religious authority. The Counc11. Reform and Reunion was published in $1960^{4}$ and Structures of the Church, in 1962.5 He also gave several lectures in Europe dealing with the significance of that synod, some of which provided the material for chapters I

${ }^{1}$ The Second Vatican Council was announced by Pope John XXIII on January $25,1959$.

${ }^{2}$ For Küng's own account of these events, see the paperback edition of The Counct1. Reform and Reuntion (New York: Image Books, Doubleday, 1965), PP. 5-8. Reprinted in W\&W, PP. 51-54.

${ }^{3}$ The first session of the Council opened almost four years after the initial announcement, on October 11, 1962.

${ }^{4}$ German original, Konzil und Wiedervereinigung: Enneuerung als Ruf in die Elnhelt (Vienna, Fribourg, and Basle: Herder, 1960).

${ }^{5}$ The German original was published in 1962: Strukturen der Kirche (Fribourg, Basle, and Vienna: Herder). Since both this book and his That the World May Believe have a Foreword signed by Kung at Tübingen on May, 1962, either of them may be considered his third or fourth published work. 
and II of The Council. ${ }^{1}$ These lectures were given in the beginning years of his academic career, after first joining the Catholic Faculty of Theology at the University of Munster (1959-60), and later (since 1960) when he joined the Catholic Faculty of Theology at the University of Tubingen.

Before the opening of the first session of Vatican II

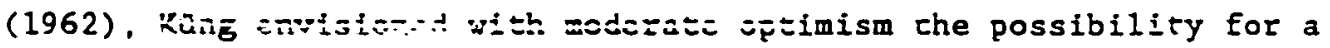
renewal and true reform within his church which could contribute to create the necessary conditions for reunion. The Council reveals this optimism. ${ }^{2}$ Addressing such issues as "The Ecumenical Tast of the Church," "The Permanent Necessity of Renewal in the Church," and "The Ecumenical Council and Reunion, "3 the book was considered "probably the most important" of the several works written about and preparatory to the Second Vatican Council. 4

$1_{\text {As }}$ indicated above (p. 159, n. 1), this is my way of referring to Küng's volume The Council. Reform and Reunion.

2 See, for instance, pp. 148-58ff., where küng notes that regarding Christian unity "the general atmosphere has changed decisively since the First World War" (p. 150), and "it is precisely among leading theologians that there is a great readiness for understanding" ( $p .151$ ). So he expresses the hope that "the next Council will be meeting in a completely different atmosphere from that of the Vatican Council" (p. 156). He remarks that "this Council does not have negative objects in view. . . but--according to the intention of John XXIII--the positive task of renewing the Church with the goal of reunion in view" (ibid.).

${ }^{3}$ Respectively, chapters 1,2 , and 5 .

${ }^{4}$ See, for instance, the reviews of The Council, Reform and Reunion, by James L. Garrect in RevExp 60 (1963): 441-43; and F. E. P. S. Langton, "Rome and Reunion," ChoR 163 (1962):392-93. From a Roman Catholic perspective, Avery Dulles commented that, in his judgment, out of the several books published after Pope John XXIII announced his intention to convoke a general council, none "is more worthy of attention" (Avery Dulles, review of The Council, Reform 
Though it has an Imprimi Potest, as well as letters of recommendation from Cardinal Lienart of Lille and Cardinal König of Vienna, 1 and while receiving in general an "enthusiastic response from the Catholic periodical press, "2 the book aroused some negative reactions from both Cathollc and Protestant reviewers. After pointing out a number of what he regards as serious shortcomings in Küng' = bont., Profecsor Joseph C. Fenton of The Catholic University of America, for instance, concluded that the book is not worth much attention, save for the necessity of denouncing its author's insufficient understanding of Catholic theology. 3

At the same time, and from a Protestant perspective, Rudolf J. Ehrlich observed that Küng's volume proposes a reunion which is

and Reunion, in America 106 (1962]:861).

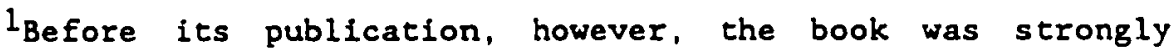
objected to by Julius Cardinal Dopfner, later President of the Conference of German Bishops. It was also questioned by Professor (later Cardinal) Hermann Volk, considered by Küng as one of three persons responsible for his opting for the academic career.

2Joseph Clifford Fenton, "The Council and Father Küng," AmER 147 (2962): 178 .

${ }^{3}$ Fenton writes in his review of Küng's book: "Too much space has already been given to the Council. Reform and Reunion. In itself the book does not merit such detailed discussion. We have treated of $1 t$ at some length here only because it has been given wide publicity, and because there is a danger that gullible young students may be influenced to imagine that this represents some new trend in Catholic theological scholarship. . . . Many of the men who have read this book have found it filled with what can best be described as "a vague, undefined discontent" with the Catholic Church, its doctrines, and its activities. . . Father Küng has written to make people think that almost everything within the Church must be changed in order to bring about the kind of reunion he desires. He has definitely shown us one factor which definitely demands improvement. That is his own grasp or understanding of the theology of the Church" (ibid., pp. 198-99). 
too Roman Catholic. Writes he: "Küng is a Roman Catholic passionately convinced that his Church is the one, holy, Catholic Church." 1 In consequence, Ehrlich notes, for the Swiss theologian the prerequisite of all true reform is obedience to the Magisterium of the Church and to the Pope. ${ }^{2}$

When contrasted with Fenton's, Ehrlich's evaluation of The Council reveals the mediating position of kung. While he is seen by some as too Roman Catholic, others consider him as not Roman Catholic enough. This seems to have been Küng's fate throughout his career.

The opening of the councll in 1962. found Küng, who had been appointed peritus by Pope John XXIII, engaged in dialogue with his Protestant colleagues of the University of Tübingen, notably Ernst Kasemann, a disciple of Rudolf Bultmann, and Hermann Diem, disciple of Barth, ${ }^{3}$ at a time when he himself was showing great interest in the historical-critical method of biblical exegesis. ${ }^{4}$

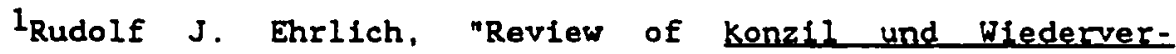
einigung," in S.T 15 (1962):207.

2Ibld., p. 208. To make his point he quotes the German original of Kung's The Council (Konzil, p. 75): "Falthfulness to the Gospel means also faithfulness to the Church which proclaims this Gospel to us. . . . Church renewal ought not to be revolutien, ought not to lead away from but more deeply into, the Church. Therefore renewal ought to be achieved in genuine, falthful, honest and free obedience to the government of the Church (Kirchenleitung) which ought to feed the sheep and through whose voice the voice of the Lord is heard" (Ehrlich, "Review," SJT 15 [1962]:207-208).

${ }^{3}$ See Küng, Councif in Action, p. 161.

${ }^{4}$ See "Interview," p. 156-57. Küng's interest in the historical-critical methods of biblical exegesis was to become a fact of major importance in his career. Granted, he had developed both an ecumenical spirit and a critical attitude toward the 
In his volume Structures, Küng criticizes more specifically and questions more openly the Roman Catholic model of ecclesiastical authority. He remarks that this book, which arose from his inaugural lecture at Tübingen in 1960 on the theology of the council, 1 contains "a vast amount of historical research." At that the and under the influence of the jus: ennounced convocation of the council, encouraged by his Church History colleague Karl-August Fink, Küng started a careful study of the whole conciliar tradition. 2 The investigation revealed something that he had recognized only instinctively before, i.e., that the Council of Constance ${ }^{3}$ provided "the opposite pole" in the history of the church to the First Vatican Council which established as doctrines of the Church, in 1870, "the supremacy of the Fope over the council and the Pope's infallibility in matters of faith and morals." 4 Published exactly one month before the solemn opening of the Second Vatican Council, 5

leadership of his church years earlier, as we have underlined. Nevertheless, and as we also pointed out, the influence of Tübingen upon this attitude, in particular the influence of an exegesis following historical-critical lines upon his dogmatic conclusions, are to be considered a decisive turning point in Küng's theological development.

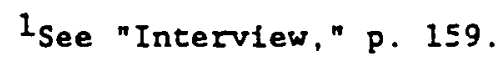

${ }^{2}$ Swidler, küng in Conflict, p. 4.

${ }^{3}$ For a brief reference to the Council of Constance, see above, PP. $71-72$. 159.

"See Küng's statement in Harfing and Kuschel, "Interview," p.

5Se Thomas F. Keane, "Review of strukturen der Kirche," in Worldmission (Winter 1962-63): 125 . 
and not without strong objections on the part of Karl Rahner. ${ }^{1}$ the book contained several ideas which were to be more fully discussed in later works like Council in Action (1963), The Church (1967), and Infallible? (1970).

While in The Council Küng addressed the issue of the active participation of the bishops together with the Pope in the decisions concerning the life, doctrines, and pollcies of the church, ${ }^{2}$ in Structures the issues were addressed from the perspective of the conciliar tradition (Chapters $1-4$ ). The volume deals also with the role of the laity (Chapter 5), of ecclestastical office and apostolic succession (Chapter 6), of the Petrine Office (Chapter 7), and infallibility (Chapter 8). This is why structures is particularly relevant for the analysis of Küng's position regarding the antithesis of orthodoxy-heresy. It deals, sometimes in depth, with several of the components of classical orthodoxy, namely, the issues of apostolic authority and succession, the normativity of the Canon and of the pronouncements of the Magisterium, and with the theological issues of the unity and catholicity of the church and its doctrine, and doctrinal infallibility as well.

In sum, during the early years of Küng's literary production, up to 1962, his growing critique of the Roman Catholic model

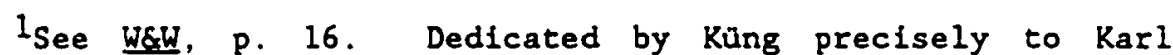
Rahner, the book was published in the series "Quaestiones disputatae" edited by Rahner himself. (About the origin of this series, see Herbert Vorgrimler. Uiderstanding Karl Rahner: An Introduction to His Life and Thought, trans. John Bowden [New York: Crossroad, 1986], pp. 80ff.).

2 Küng, The Council, pp. $159 \mathrm{ff}$. 
of religious authority was prompted by his interest in contributing to the creation of an atmosphere favorable to a frultful ecumenial dialogue. Küng's concern about "the unification of all Christians" was so essential that one can find it reflected not only in the books he wrote prior to the opening of the council, particularly Structures and May Believe, 1 but also in Council in Action ${ }^{2}$ and others after it.

Küng's critique of Catholic author-

ity at the time of Vatican II and afrar

The period comprised between 1962 and 1970 is mcst significant in Küng's career. It is full of both happy and bitter moments for him. He became at that time a popular figure who transcended the theological community. In 1963, he accepted the directorship of the newly established Institute for Ecumenical Research at the Untversity of Tübingen, and was cofounder, in the same year, of the international theological journal Concilium. He also participated in lecture tours and symposia in Europe, North

$1_{\text {Also }}$ published in 1962 , the work was evaluated as a "splendid book, both instructive and inspirational," that would be of special interest to those among the Catholics "whe are In close contact with persons of other falths" (Vincent de Paul Hayes, America 108 [1963]:446).

${ }^{2}$ See above, p. 159, n. 1. The German original is Kirche im Konzil (Fribourg, Basle, and Vienna: Herder, 1963). The book has been published in the U.K. as The Living Church (London: Sheed and Ward, 1963), and as The Changing Church (London: Sheed and Ward, 1965). The Preface was signed at Tubingen in December 1962.

During the first session of Vatican II, Küng lectured in Rome to "numerous meetings of bishops... . In pontifical colleges and houses of orders, in press conferences and broadcasts" (see Küng, Council in Action, p. v). These conferences are collected in the referred volume. 
America, the Near East, and India, 1 recelving honorary awards and degrees. He appeared criticizing papal pronouncements in the media, $\bar{z}$ and, in addition to the works already mentioned, published several other books. ${ }^{3}$ During the same period, Kung suffered some admonitions from Roman Catholic authorities, 4 as well as the

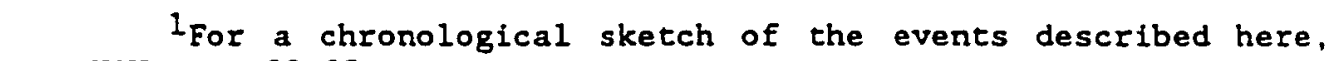
see W\&W, Pp. 20-25.

${ }^{2}$ Kung publicly ralsed objections to Pope Paul VI's encyclicals on priestly celibacy, Sacerdotalis caelibatus (June 24 . 1967), and on the moral principles governing human procreation, Humanae vitae (July 25, 1968). For an English translation of these documents, see PopeSp 12 (1967):291-319; and 13 (1969):329-46. Küng also objected to the papal motu proprlo apostolic letter on mixed marriages (March 31, 1970). For an English translation of this document, see PopeSp 15 (1970):134-39.

${ }^{3}$ Küng, Freedom in the World: Sir Thomas More (London: Sheed and Ward, 1965), published also in Küng, Freedom Today (New York: Sheed and Ward, 1966), as chapter I, PP. 1-31 (German original, Fretheit in der Welt: Sir Thomas More. Theologische Meditationen I (Einsiedeln: Benziger Verlag, 1964)]; Küng. The Theologian and the Church (London: Sheed and Ward, 1965), also included as chapter III of Freedom Today, pp. 65-108 (German original. Theologe und Kirche, Theologische Meditationen 3 (Einsiedeln: Benziger Verlag, 1964]); Küng, The Church and Freedom (London: Sheed and Ward 1965), also included in Ereedom Today as chapter II, Pp. 33-64 (German original, Kirche in Freiheit, Theologische Meditationen 6 [Einsiedeln: Benziger Verlag, 1964]); Kung, Christenheit als Minderhelt, Die Kirche unter den Weltrelizionen, Theologische Meditationen 12 (Einsiedeln: Benziger Verlag, 1965), Eng. trans. In Freedom Today, pp. 109-61; Küng, Gott und das Leid, Theologische Meditationen 18 (Einsiedeln, Zurich, and Cologne: Benziger Verlag, 1967); Küng, Menschwerdung Gottes (1970); and Küng, Was ist Kliche? (Fribourg, Basle, and Vienna: Herder, 1970).

${ }^{4}$ In 1965, Küng received a warning from Cardinal ottaviani at the Holy Office because of his negative assessment on the achievements of the council (see W\&W, p. 23). He also received a letter, dated April 30, 1968, from the Holy office (renamed the Congregation for the Doctrine of the Faith in 1967) summoning him to the Vatican for a discussion on his book The Church. For the text of this letter and subsequent correspondence between Küng and church authorities, see Küng Dlalogue, pp. 19-20ff. In addition, on February 8, 1971, the Conference of German Bishops issued a statement against Infallible? (see the text in Küng Dialogue, PP. 
174

prohibition by a decree of the Holy office in 1967 to publish and translate The Church until a discussion had been held in Rome. 1

From the mid sixties onward, Küng's questioning of the Roman

Cathoilc model of ecclesiastical authority turned increasingly

radical. Two major factors seem to have played a decisive role in this development. The first is his Increasing acquaintance with Protestant theology and its historical-critical-exegetical approach. which had taken place in Tubingen starting in 1962. Secondly, the shift in the mood of the councll ltself after its first session (1962) must be regarded as of no little significance.

The latter factor needs a word of comment at this juncture. Up to the first session of the Second Vatican Council, Küng could only be satisfled with the pace of the agglornamento. His previous book about the upcoming general synod. The Council, had proved to be

40.41). Four days later the Congregation for the Doctrine of the Fafth sent a letter to Küng questloning the absence of Imprimatur in the same book and admonishing him for publicly urging people to "disobey legitimate authorities, as for example in the question of mixed marriages" (see Küng Dialogue, p. 42).

${ }^{1}$ still, the book continued to be translated and published in several languages. Though Hans Kung's dossier 399/57/1 was started by the Index Defirtment of the Holy office soon after the publication of Justification (1957), the real controversy between the Swiss theologian and the Congregation for the Doctrine of the Faith [CDF] started in 1968 when the CDF invited Küng to the Vatican to discuss his book the Church (see küng in Conflict, pp. 10ff). Two points were regarded as of particular importance, namely, the unity of the church and the necessity of the sacrament of orders for a valid celebration of the Eucharist. The CDF had difficulties with Küng's notion that "the Church of Christ. . . consists of all the Churches and ecclesial communities," and with his conjecture that "in abnormal sases the Eucharist may be consecrated by baptized persons without sacerdotal ordination" (see Kung in Conflict, pp. 44-45). 
"an amazingly accurate prophecy of the spirit of Vatican II." 1 Küng made public the satisfaction that the results of the first session of the Council originated in him in a letter he wrote to Father Van Ackeren on May 8, 1963.2 The death of Pope John XXIII (June 3. 1963) before the opening of the second session of Vatican II, however, was to change the state of affairs for both Küng and the council in progress. John XXIII, for whom Küng had great admiration, ${ }^{3}$ had appointed him an official theological adviser to the counc1l. Conversely, under Pope Paul VI the Holy Office (In 1963. during the second session of Vatican II) started doctrinal

$1_{\text {Comment }}$ on the jacket of Council in Action. published by Sheed and Ward of New York, in 1963. As for his volume The Council, Küng remarks that the developments of the Second Vatican Council "have stamped it as 'prophetic'" (Küng, "Looking Back," W\&W, p. 53).

${ }^{2}$ The letter of Küng was published as an editorlal under the title "Father Kung's Reflections on the Council," In Theology Digest 11 (1963):65:

"The results of the first session of the Second Vatican Council have far exceeded my expectations. The pope and bishops have done a wonderful work. The most important positije results of the first session seem to me to be the following:

1. the new consciousness of the Church as the living and free community of the falthful, of which the ecumenical council is a representation;

2 . the opening of the whole Catholic Church toward the unification of all Christians;

3. concentration on the pastoral renewal of the Church rather than on the shutting of doors in matters of doctrine:

4. the decisions on the basic norms for liturgical reform;

5. the decision to reorganize the whole work of the council, which guarantees a better preparation for the second session.

What do we need for the second session? Watchfulness, boldness, clear-sightedness, endurance, strength, and prayer."

${ }^{3}$ See Küng, "Looking Back," in W\&W, p. 51-52: "I owe an inexpressible debt of gratitude to John XXIII, a true 'man of God' $\because=$ so many inside and outside the Catholic Church. . . More than almost any Pope before him, he gave new meaning to the Gospel of Jesus Christ. . . . It is due to him that this book [The Council. Reform and Reunion] had a future." 
proceedings against Küng's structures. ${ }^{1}$ The investigative sessions were halted, thanks to the influence of Augustin Cardinal Bea who was put in charge of the proceedings. ${ }^{2}$ These facts, as well as what some regarded as the subsequent stagnation of progress of the council, cannot be overlooked in analyzing the evolution of Küng's concept of religious authority. Disappointed by the way the council was developing. Küng returned to Tübingen earlier than planned during its third session (September 14-November 21, 1964). Though not without hope of further progress and while acknowledging that many doors had been opened for the first time, he expressed some negative judgments on that session in an article for a German perfodical, translated later into English as "The Council--End or Beginning?"3 His negative assessment is capsulized in the following statement: "The observer who evaluatas the Council from within the Catholic Church will find sufficient grounds for good cheer, the one who evaluates from the ecurenical viewpoint, for dejection." 4

1 The controversial nature of this book led the Catholic University of America, in Washington. D.C., to ban Küng from lecturing there during his first lecture tour in the U.S.A., which took place in March and April, 1963 (see W\&W, pp. 18, 19).

${ }^{2}$ See Küng's own account of the facts in "Interview," pp. 159-60. Cf. Swidler, küne in Conflict, pp. 4-5.

$3^{3}$ Published in The Commonweal 81 (1965):631-37. The original German edition, "Das Konzil--Ende oder Anfang? Eine Bilanz am Ende der dritten Sitzungsperlode des Zweiten Vatikanums," was first published in Erankfurter Allgemeine Zeitung, 18-19 Nov., 1964, revised and expanded in Clvitas 21 (1965):188-99, and other periodicals. $(1963): 633$.

"Küng, "The Council--End or Beginning?," The Commonweal 81 
The critical views regarding ecclesiastical authority. heresy, and related issues expounded lacer in his book The Church (1967), 1 should be seen against the background of what was happening during the development of Vatican II. Further objections to the Catholic model of teaching authorlty would appear in Truthfulness (1968), 2 and esperially in Infallible? (1970), 3 which aroused numerous negative reactions and widespread theological discussion. ${ }^{4}$ The controversy which started at the time of the publication of The Church was to increase in intensity after Infallible? was published in 1970. Things would not improve for küng. Less than a decade later, 1979 would prove the decisive year in the küny case. After writing the introduction to August Bernhard Hasler's polemical volume How the Pope Became Infallible ${ }^{5}$ and publishing, the same

IOn which Küng started to work in 1963 (see W\&W, p. 18).

${ }^{2}$ German original, Wahrhaftigkeit, Zur Zukunft der Kirche, Kleine okumenische Schriften 1 (Fribourg: Herder, 1968).

3Unfehlbar? Eine Anfrage (Zurich: Benziger Verlag, 1970).

"In reaction to Küng's Infgllible?, Karl Rahner edited a series of negative analyses in Zum Problem Unfehlbarkeit. Antworten auf die Anfrage von Hans küng (Fribourg, Basle, and Vienna: Herder, 1971), 376 pP. Among Kung's critics, besides Rahner, were Juan Alfaro, Yves Congar, Heinrich Fries, Joseph Ratzinger, Leo Scheffczyk, Rudolf Schnackenburg, and Herbert Vorgrimler. Küng answered with a massive volume ( 525 pages) of essays written by theologians who defended his position: Hans Küng, ed., Eehlbar? Eine Bilanz (Zurich, Einsiedeln, Cologne: Benziger Verlag, 1973). In the North American milieu another important symposium on the issue was published: Gregory Baum et al., The Infallibility Debate, ed. John J. Kirvan (New York, Paramus, and Toronto: Paulist Press, 1971). In addition, innumerable articles and reviews in theological journals and magazines, both in Europe and America, particlpated in the theological debate sparked by Küng's work.

${ }^{5}$ German original, A. B. Hasler, Wle der Papst unfehlbar wurde: Macht und Ohnmacht eines Dogmas (Munich: R. Piper \& Co. 
year, his brief "theological meditation," The Church--Maintained in Truth, Küng's canonical mission was withdrawn by the Vatican shortly before Christmas, taking him totally by surprise.

In conclusion, even though küng recognizes the validity of the principle of authority in the church, his writings reflect his awareness of the fact that today "there is no longer any eternal truth that cas s:ade the cisicical judgment of rcason by appeal merely to the authority of Bible, tradition or Church."I

Let us, at this point, further explore Küng's position on doctrinal authority by addressing his concept of revelation and his views on the norms of classical orthodizy relaced to the revelational criterion, namely, the apostolic teachings and the NT Canon.

\section{Revelation as a Criterion of Orthodoxy}

An analysis of Küng's writings reveals that he has not dealt at length with the doctrine of revelation nor with the relationship existing between his own view of revelation and the traditional revelational criterion of orthodoxy. When küng refers to the issue. briefly and in passing, his attention concentrates mostly on the question of the inspiration of the biblical writers. ${ }^{2}$ In this context, his main interest is to underline the inappropriateness of the verbal theory (or "dictation" theory) of inspiration and, as a

Verlag, 1979). Küng's Introduction, "The Infallibility Debate: Where Are We Now?," is dated Tübingen, February 1979.

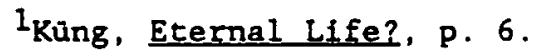

${ }^{2}$ See, for instance, The Church, pp. 35-46; Infallible?, pp. 209-21; Christian, Pp. 263-68; Kung et al., World Religions, Pp. 30 33; Theologie im Aufbruch, pp. 76-78. 
corollary, the human frailty and capacity for error of the authors of the biblical writings. 1

As for revelation itself, i.e., the doctrine that the Christian religion derives its fundamental beliefs from God's own testimony, Küng subscribes to the view that God did manifest himself to the human race. God has spoken. 2 It is therefore not the whether but the mode of revelation, the manner in which, according to Küng, divine revelation occurs which retains our attention. This issue is of fundamental importance since it bears upon Küng's understanding of the nature of the canonical scriptures and, hence, upon the hermeneutical principles he uses in his search for Christian truth.

Küng's most explicit statement of his position on this matter is found in an article entitled "Toward a New Consensus in Catholic (and Ecumenical) Theology." 3 Here, he affirms his "fundamental hermeneutical arreement" with the principles expressed by Edward Schillebeeckx. This comparison made by küng of his own theology and that of Schillebeeclox, though "not in a detailed fashion but only in their main features," is most appropriate for our purposes. 4

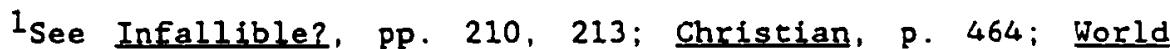
Religions, Pp. 31, 32; Theologie in Aufbruch, pp. 77,78 .

2 In this sense, kung cannot be counted with the proponents of the extreme liberal position that sees Christianity as a step in the evolution of religion, which is in turn regarded as a merely human phenomenon.

${ }^{3}$ See Swidler, ed., Consensus in Theology?, pp. 1-17.

${ }^{4}$ See Küng, "New Consensus," PP. 4, 3; emphasis his. As Küng 
We should notice, first, that for kung contemporary theology, "the only theology. . . that could survive the future," can draw upon two sources. These are "God's revelational address in the history of Israel and the history of Jesus" and "the contemporary human experiences of Christians and non-Christians." 2 what interests us at this point is that God's revelation is recognized by Küng not only as a source of theological knowledge but, in fact, as "the firct 'source,' pole, and standard of Christian theology." 3 As we noticed earlier, a return to the sources, a "theology of Christian origins and center enunclated within the horizon of the contemporary world," is deemed by kung as the only legitimate way of doing theology in today's world. ${ }^{4}$

Not only does kūng believe in divine revelation, he also agrees with Schillebeeckx that this revelation "does not originate in subjective human experience and reflection." Human experience, though deemed by him a source or pole of Christian theology, is not to be identified with revelation. The origin of revelation is not at the level of human experfence but at the level of the divine.

himself obserres, his theological and hermeneutical principles are also expounded and applied in two of his major books, namely, on Being a Christian and Does God Exist? ("New Consensus," PP. 3-4).

I"New Consensus," p. 2.

2 Ibid., pp. 4, 5, 11.

${ }^{3}$ Ibid., p. 5.

${ }^{4}$ Ibid., p. 3. As noted in several places throughout this dissertation, in Küng's view all Christian theological reflection must be rooted on the normativity of the original witness to the gospel, namely, on the apostolic proclamation as recorded in the canonical Scriptures. 


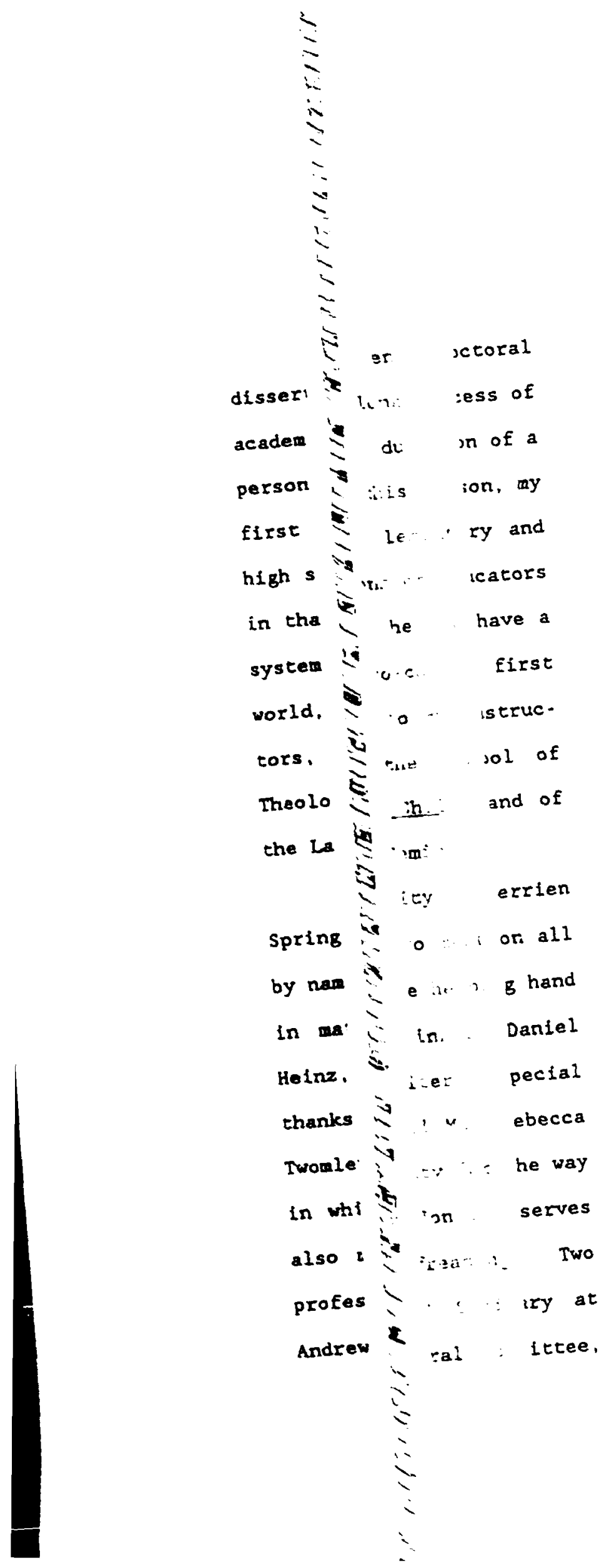

Reproduced with permission of the copyright owner. Further reproduction prohibited without permission. 
"God's revelation is not a human product or profect," remarks küng, who adds, "Human experfence is not the ground of God's revelation." 1 In the phenomenon of revelation it is not man who speaks but God. still, "God speaks through humans." 2 While this means that the prophets and sacred writers are human beings, it especially aenoces that as insplred authors the biblical writers cannot "appear as unhistorical-phantom beings through whom the Holy spirit effects everything directly." 3 Küng holds that inspiration does not mean "the exclusion, repression, or replacement of the human activity of the haglographers." God takes a human author with all his weaknesses and failures "and still achieves his aim of teaching man the 'truth' of revelation."4 Thus, in addition to his taking seriously the human dimension in the phenomenon of revelation, we may conclude that for küng the latter implies the communication of teachings or truths. 5

Looking at the issue from another perspective, we may note that Kung's rejection of the two-tler conception of the structure of reality is consistent with his opinion that -Divine revelation and

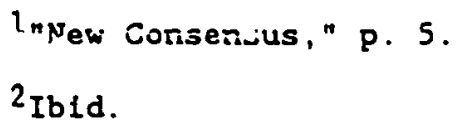

${ }^{3}$ Kung, Infallible?, n. 200. "While Palestinian Judaism did Indeed see God himself at work in the biblical authors, but took serfously their human and historical peculfarfties,. . . in Hellenistic Judaism (especially Philo) an attempt was made to exclude these peculfarities," observes küng (Infalible?, p. 211).

${ }^{4}$ Ibid., pp. 213, 214; cf. Christian, pp. 461-66, on inspiration; and ibid., pp. 466-68, on the Scriptures as the word of God.

${ }^{5}$ In this sense, he cannot be considered as clinging to the "encounter theory" of revelation. 
human experience are not simply antithetical." 1 If God and man share in the one and same reality, God's revelation must be necessarily given in the frame of that reallty, a part of which is directly accessible to man. On the other hand, God's revelation, his "teaching man the truth," 2 "is only accessible through human experience." This means that for küng (and Schillebeeckx) "there is no revelation outside human experience. " 3

This view is not to be interpreted as a denial of the existence of an objective reality beyond human experience or perception. What it underlines is that revelation is a relational phenomenon; that when God reveals, he not only reveals himself or some truths about himself, but he reveals to somebody. In this way Küng can assert that Jesus of Nazareth is "the definitive revelation of God in the history of Israel, " not merely because "he was such for them (objectively)" but also because "he was so experienced by his first disciples (subjectively)." Thus, concludes Kūng, we have revelation coming "from above," from God, but we also have revelation "continually experienced, interpreted, verified and then made the object of theological reflection 'from below' by humanity. " 4

Küng further specifies his concept of revelation when he writes that "The human experience of revelation is not interpreted

\footnotetext{
I"New Consensus," p. 5.

2 Infallible?, p. 214.

$3^{3 n}$ New Consensus, " p. 5.

4 Ibid.
} 
after the fact." 1 The interpretive act is an "inner moment of the experience itself, at first unexpressed and known later upon reflection." This amounts to affirmation that no revelation is ever "pure." 2 The things revealed and expertenced cannot be experienced out of experience. Though tautological, this needs some emphasis, especially since Küng himself does so. God obviously can formulate a revelation by writing it down directly, as it were, without human involvement of any sort. In this sense, the content of the "revelatIon" (even though not revealed to anybody) could be considered as "pure." However, as soon as it enters in contact with a single individual's consclousness, it is "received" through a process of interpretation. God's revelation "is always given from the outset through the medium of human interpretation ${ }^{3}$ and in human language and categorles ${ }^{4}$ - to be true, tho vnly meaningiul possibility.

Within the bounds of the intra-Catholic discussions which took place during the early years of his theological development, Küng stressed the norms related to the revelational criterion of Christian truth over against those belonging to the category of the ecclesiastical criterion. Even though he may not have dealt at length with the doctrine of revelation nor with the relationship existing between his own view of revelation and the traditional

I Ibid; emphasis supplied.

2 This is Küng's wording; see lbid.

${ }^{3}$ Ibid.

4"Language" in the sense of means of communication, not restrictedly in the sense of the speech of a particular nation. 
revelational criterion of orthodoxy, his sonfessed ultimate norm of Christian truth falls within the realm of the latter criterion: it is the gospel of Jesus Christ as originally proclaimed by the apostles and recorded in the NT Canon. To analyze this particular position the following two sections are devoted.

\section{The Teaching of the Apostles as a Norm of Orthodoxy}

Küng's emphasis on the foundational and normative nature of the proclamation and teaching of the apostles as recorded in the NT Canon is one of his characteristic notes. First, he underscores the unique, unrepeatable character of the apostolic testimony: the apostles are the original witnesses of God's revelation in Christ. the first eyewitnesses of the Lord's resurrection, and the original bearers of the calling to proclaim the gospel. Second, he stresses both the temporal and the normative precedence of the apostles' office. On this basis, Küng observes that the apostles' teaching constitutes "for all time" the "standard" testimony to Jesus Christ. As representatives of Christ, the apostles are to be regarded as invested with the Lord's authority. At the same time. however, they are part of the church and under Christ and his teaching. They are not above the Church, but in the Church, where they serve as a bond of unity. Thus, the succeeding offices of the church are to preserve and interpret the apostolic witness and proclamation of the gospel. In other words, on the one hand the teaching role of the post-apostolic church is primarily one of preservation as weli as of translation of the original deposit of 
faith, not one of adding to it. On the other, the teaching role of the church is one of interpreting the foundational apostolic proclamation, since the apostolic teaching is not to be simply repeated in a parrot-1ike way. 1

In his classic The Church (1967), Küng further addresses the question of what it means to affirm that the church is apostolic. His answer includes two major elements. First, the church is apostclic in the sense that it is founded on the apostles original. unrepeatable witness to Christ and on their teaching. ${ }^{2}$ second, the church is apostolic because it is the successor of the apostles. The preaching of the apostles being valid till the end of time, the church is the follower of the apostles, pursuing their mission and task. This implies, of course, that in the apostolic ministry of the whole church there is "an apostolic succession of obedience." 3 Kung's two-fold answer to the question regarding the apostolicity of the church raises, in turn, two other questions, namely, What does "apostle" mean? and What is the signiticance of "apostolic succession? $n$

Addressing the first question and using the historical-

This deserves further attention since it is of central importance to the issue of orthodoxy and heresy. The theological issue of continuity and change in theology is involved here, as well as the questions concerning the nature of truth as such and human apprehension of truth.

${ }^{2}$ See The Church, pp. 443-55, especially pp. 450, 452-53, 456.

${ }^{3}$ Ibid. , Pp. 455-61, especially pp. 456-57.

${ }^{4}$ Ibid., pp. 444, 456 . 
critical method, 1 küng notes that the identification of the title apostle with "the twelve" occurs late in the development of the church. At the beginning, the term apostle is appiied in the wider sense of "ambassador" and "authorized messenger." It can refer to the twelve as well as to all missionaries of the gospel or "messengers of the Churches" (1 Cor 12:28; 15:7; 2 Cor 11:5; 2 Cor 8:23; PhIl 2:25). It was Paul in his argument with the Galatians (Gal 1 and 2), Küng observes, who "made the notion of the apostle as the authorized representative of Jesus Christ himself central to his theology."2 The notion of apostleship "in the full Pauline sense of the word" was eventually limited to "the twelve alone, with the possible addition of Paul." 3 The connection of the Christian idea of apostleship exclusively with the twelve chosen by Jesus during his lifetime obeys to the development of a "strictly cheological concept. 4

As to the authority of the apostolic ministry, kung holds that the apostle is not "simply the messenger of a community, but has been appointed by Chrlst (Gal 1:15f.; Acts 9:27; Mark 3:4 par.; Matt 28:19)," he has been "sent and authorized by the Lord himself." He performs his task authoritatively, and as such he preaches the

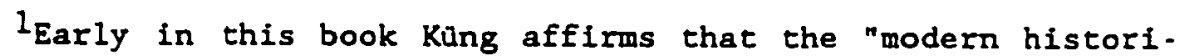
cal-critical method provides the theologian of today with a scholarly instrument for investigating the origins of the Church which an earlier generation of theologians did not possess" (The Church, p. 41).

2Ibid., p. 451.

3Ibid., pp. 451-52; cf. Bultmann, Theology, 2:105, 139.

${ }^{4}$ For this specific matter, see kung, The Church, p. 452. 
gospel, gathers the bellevers together, founds and leads the churches, exercises discipline in the churches, gives instruction for ordering the life of the community, and devotes himself to the unity of communities by means of journeys, messengers, and letters. In accomplishing his task and mission, however, the apostle "does not act in an authoritarian manner." "He does not act in isolation but in fellowship with all the members of the community." In brief. "he is not to be the lord of the Church, but its servant. . his apostleship is an office of service." I Addressing the question as to "What is apostolic succession," Küng observes that the experience of the apostles as witnesses of God's revelation in Christ being unique and unrepeatable, they "can have no successors." He points out the fact that no further apostles were salled or chosen by the church after their death. St11l, the apostolic mission remains and so too does the apostolic ministry. It is in the continuity of the apostolic ministry that an "apostolic succession" exists, which fmplles not only a few individuals but the whole church. ${ }^{2}$ In this sense, holds Kung, apostolic succession must be understood in terms of "substance, not fust of history." It is "a thing of the spirit," which means that the authority implied in the apostolic succession is a charisma granted by the same Spirit who filled the apostles and their witness. The link between the church of any age and the foundational proclamation of the apostles is lllustrated in two

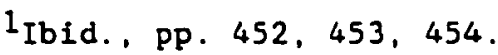

${ }^{2}$ Ibid., pP. $456-57$
} 
ways, Küng notes: The church is apostolic (I) when it remains in agreement with the original witness of the apostles, and (2) when it continues the apostolic ministry. "Together with the apostles the Church must serve the Lord." 1

The Canon of the New Testament as a Norm of Orthodoxy

In the context of apostoilc authority, orthodox belief, and preaching, Küng is very much aware of the role and function of the New Testament writings. He observes, for instance, that "the preaching of the apostles, as it has come down to us in the writings of the New Testament, is the original, fundamental testimony of Jesus Christ, valid for all time." 2 Let us consider Küng's view of the nature and authority of the NT Canon, that second norm of classical orthodoxy which developed during the first centuries of the church's history.

The understanding of the formation and role of the NT Canon is not without its vexing problems. One of them has to do with the contention whether the canonization of the NT documents is merely the result of an arbitrary sifting made in the fourth century by the imperial church or whether it is a divinely guided process of selection of genuinely inspired books. Those who cling to the second alternative maintain that just as the evangelists selected

'Ibid., pp. 457-59. We return to the subject of Küng's understanding of apostolic succession when the issue of the episcopal magisterium is discussed in the context of the continutty of the Christian doctrine.

${ }^{2}$ Ibid. . p. 456. 
and arranged their material in the Gospels on the basis of specific theological concerns and under inspiration, similarly later Christians were also guided by God to use their theological criterion in the formation of the Canon.

A second difficulty related to the nature of the New Testament concerns the diversity of its documents. While the importance of this diversity has often been traditionally disregarded by both Catholic and Protestant orthodoxies, the current tendency is to emphasize it. Some scholars even present us with a view of the NT as an awkward collection of dissimilar and contradictory documents. 1

Within this context, how does küng view the Canon of the NT. which he credits, virtually throughout all his writings, as the norma normans of Christian doctrine? How, in particular, does he regard the nature of the NT canon of Scrlptures? And how does he understand its role in the definition of true belief and teaching? ${ }^{2}$

lypical of this view is Helmut Koester's statement: "The term sanonical loses its normative relevance when the New Testament books themselves emerge as a deliberate collection of writings representing various divnrgent convictions which are not easily reconclled with each other" (Helmut Koester, "GNOMAI DIAPHOROI: The Origin and Nature of Diversification in the History of Early Christianity," in James M. Robinson and Helmut Koester. Irafectories Through Early Christlanity [Philadelphia: Fortress Press, 1971], P. 115).

The question is the more interesting since Küng, from 1962 on, let the historical-critical method play an increasing role in his exegetical and theological work. In an important article. written in 1979, in which he expounds his theological method, the Swiss theologian remarks: "The New Testament, the original witness to this Christ, which today we must interpret historically-critically is and remains for Christians the definteive norm (norma normans) for all post-biblical tradition" ("New Consensus," p. 17). 
Küng studied the issue of the New Testament, adopting a historicalcritical approach, and engaged in a "three-comered discussior" with two of his Protestant colleagues at the University of Tübingen-Ernst Kasemann and Hermann Diem. The first result of this careful investigation appeared, he tells us, in his article "Early Catholicism in the New Testament as a Problem in Controversial Theology."I Addressing the "crucial question of Catholicism in the New Testament," 2 one of the central concerns of the article is the issue of whether the canon of the NT is the foundation of the unity of the church. ${ }^{3}$ Agreeing with some of Kasemmann's and Diem's postulates. Kung describes his own position as essentially "Cathollc" and different from those of his two Protestant colleagues. Kasemann's answer to this question, Küng notes, is "sharply" negative. Among Kasemann's reasons for such a view, küng lists: (1) the variability of the NT kerygma, (2) the extraordinary abundance of theological positions in primitive Christianity, ranging beyond the limits of

$1_{\text {German original, "Der Frühatholizismus 1m Neuen Testament }}$ als kontroverstheologisches Problem," Theologische Quartalschrift 142 (1962):385-424. Also published in Küng's Kifche im Konzil (1963); Eng. tr. by Cecily Hastings, in Council in Action, pp. 15995. Reprinted in A. Danhardt, ed., Theologisches Jahrbuch (Leipzig, 1965), Pp. 150-77; and in E. Kasemann, ed., Das Neue Testament als Kanon (Götingen, 1970), pp. 175-204. That study has been included without substantial modification in Küng's recent volume Theologie in Aufbruch: Eine okumenische Grundlegung (Munich and Zurich: Piper Verlag, 1987), PP. 88-108.

2 Küng, Councti in Action, p. 181.

${ }^{3}$ Ibid., p. 161. Küng, in this discussion, sets his two Protestant colleagues in confrontation with each other. 
the NT, and (3) the partially visible incompatibility between theological positions within the NT. 1

Küng subscribes to Kasemann's view on the Canon of the New Testament that its "non-unitary character" results from "a variability in the New Testament kerygma itself," which in turn is due to the "individual character of the Evangelists" and to their different theological interests. He also sides with kasemann on the hearing in falth and according to the Spirit--not the letter--within this non-unitary Canon of the NT, of the gospel of justification by faith: ${ }^{2}$ and that the Canon of the NT does lie at the root of the existence of a multiplicity of Christian confessions, to the extent that all of them appeal to the New Testament. ${ }^{3}$

At the same time, Küng talres Kasemann's theses to task by observing that in order to be accurate, one should say that the NT Canon is "a necessary presupposition and occasion for confessional multiplicity, but not strictly its root or cause." 4 The actual cause of the multitude of Christian confessions, Küng affirms, is the selective, "un-catholic" way of understanding the New Testament. He also notes that "Kasemann is an example of this kind of selection" because he determines, first, that the justification of the

1 Ibid., pp. 161-63. It should be observed that at the core of the discussion in this article are the two theological issues mentioned above, namely, the related problems of the formation of the canon of the NT, and the diversity of its documents.

${ }^{2}$ For the first two polnts of agreement between küng and Kăsemann, see Küng, Council in Action, p. 170.

3Ibid., pp. $171-72$.

${ }^{4}$ Ibid., p. 172; exphasis in the original. 
sinner is "the canon" within the NT Canon, and then refuses to hear "the Gospel" in those passages which he regards as unevangelical. 1

Küng's own position regarding the Canon of the NT as contrasted with Kasemann's view may be summarized as follows: "With all its lack of unity, the Canon of the New Testament is neverthe. less one thing, and has been recelved by the Church as one thing. " 2 For küng, the key element for the acceptance of the NT Canon as one body, for all its diversity, is "the Church, who stands behind the Canon." 3 This view touches upon both the issue of the unity of the NT and its historical formation as Canon.

When we do not accept the Canon as "one thing," Küng holds, and, furthermore, when we do not strive to reach "a comprehensive understanding of it." we are guilty of abandoning "the wholeness of the New Testament. . . In favour of the concentration afforded by selecting." This is "nothing less than the aivandonment, fundamentally, of satholfeity in the understanding of Scripture in favour of heresy. $" 4$

Notice first Küng's attftude toward the two theological issues referred to in his dialogue with kasemann. As for the problem of the formation of the NT regarded as an arbitrary sifting of documents, Küng would answer that Christians are to accept "what has been received by the Church." The church has received the NT

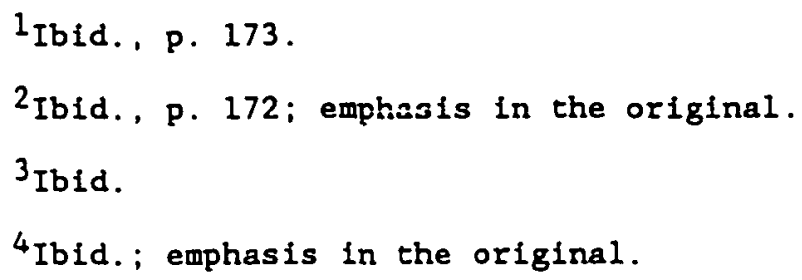


Canon as one thing "in the course, certainly, of an extraordinarily changeful history," but the various testimonies found in it should be understood as "an expression and crystallization of the Gospel." We may conclude that for kung to question the divine nature and authority of the Canon handed down by the church would be to question the legitimacy as well as the unity of tho arurah itself "who stands behind the canon." 1 Küng further elaborates this issue in his book The Church. Some of his statements there are worthy of being quoted at this point. Describing the church's work of preserving the word of God, Kung writes:

The New Testament "canon," a norm, a guideline and a boundary . . . represents a via media. The Church dfd not, like Marcion and some present-day Protestant theologlans, vant to narrow down the choice by radical reduction until only the true "evangelium" was left; nor, like the gnostics and some presentday Catholic theologians, did it want to make its choice as wide as possible, including apocryphal writings and "traditions." The New Testament canon was not selected on the basis of an a priori principle, but pragmatically; the living faith of the Christian communities was called upon to "discern spirits." 2

As far as the diversity found within the NT is concerned, kung prefers to stress its oneness. Several times in this essay ${ }^{3}$ he repeats that the "wholeness" of the NT should be taken serfously and, hence, it should be understood "comprehensively." This point is affirmed again in Küng's structures, in the context, once more, of a discussion on "early Catholicism" in the New Testament:

IIbid.

${ }^{2}$ Küng, The Church, pp. 35-36; emphasis his. Cf. my discussion on the formation of the canon of the NT above, Pp. 43-50.

${ }^{3}$ I am referring to "Early Catholicism in the New Testament as a Problem in Controversial Theology." 
The New Testament as a whole is the testimony of the most comprehensive, that is, catholic, truth in its fullness. To recognize only part of it means to choose, which means heresy. . . The whole New Tesiament must be given full value though historically differentiated and translated in terms of the present. 1

Equally significant in the context of this dissertation is Küng's concept of heresy as choice, selection, or discrimination within the Canon. ${ }^{2}$ This concern is already present in Irenaeus of Lyon (c.135-c.202 A.D.). He explains that one characteristic of heresy is the fact that each heretic selects part of the whole apostolic witness and elevates the authority of one apostle above that of the others. ${ }^{3}$ For those who, like Küng, hold a "cathoilc" view of the Canon, the diversity found in the NT, far from being a problem is a token of its non-heretical nature. ${ }^{4}$ One of the most serfous shortcomings that kung sees in Kasemann's approach to the NT (In this spectelc point he agrees with Diem ${ }^{5}$ ) is precisely the latter's subjective selecting of "a Canon within the Canon." This, according to küng, is "selection as a matter of principle." 6

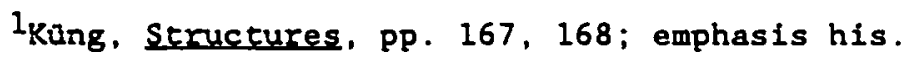

2 This notion recurs in his writings; see, for instance, The Church, pp. 40, 318-19 passim.

${ }^{3}$ Izenaeus Adversus haereses 3.11 .7 (ANF, 1:428).

"Kung would answer Koester's contention that "the criterion 'apostolic' is useless when Christian movements that were later condemned as heretical can claim genuine apostolic origin" (Koester, "GNOMAI DIAPHOROI," p. 115) by affirming that the problem with "heretics" is not that they claim apostolic origin (in this they may be right), but that they "select" one apostolic witness from the multiple witness of all the apostles.

Souncil in Action, p. 167.

${ }^{6}$ Ibid. , pp. $173-76$. 
Kung's concept of the cathollcity of the Canon is closely related to tha cathollcity of the church, so that, for him, any "protest agalnst the catholicity of the Church inevitably turns into a protest against the catholicity of scripture." 1 The antithesis wholeness-selectivity (or catholicity-heresy) is not restricted to the hermeneutical question regarding the NT Canon. It involves the whole IIfe of the church as well. 2 In brief, it was the "catholicity" of the primitive church which permitted the formation of the NT as we have it. At the same time, it is the "catholic" nature of the Canon, understood as the crystallization of the same gospel proclaimed in different settings, that shaped a catholic Christianity.

As for Küng's position as contrasted with Diem's view, in his opinion a Catholic theologian can agree with Diem on several points. Catholic theology would grant that the writings assembled In the NT Canon do not present a unity of doctrine. The NT is not a dogmatic system; it is not incended as a summa theologiae. This Implies that Ghristian faith does not focus merely on Scripture but on the Lord, to whom it witnesses, and on his Father. Besides, it is important to recognize that the witness of the NT is given by

1 Ibid., p. 183.

${ }^{2}$ In this respect Jaroslav Pelikan notes that even though the primitive church was not characterized by an explicit unity of doctrine, it was characterized by a "unity of life, of fidelity to the Old Testament, of devotion, and of loyalty to lts Lord,. . . Heresy was a deviation from that unity" (Jaroslav Pelikan, Catholic Tradition, p. 70). Küng would only agree with this statement because he believes that "the unity of the body of Christ is always endangered . . . by heresy" (Küng, The Church. P. 313 ; emphasis his). 
different people in different situations with different theological ends in view. This witness, according to küng, "must once more be uttered for different people with different ends in view in different situations." Finally, one ought to recognize the practical nature of the Canon of the NT whose unity "cannot be deduced by regarding it as a closed sysrem." It is the unique and exclusive collection of testimonies through which the church has heard the voice of God proclaimed, and which it, in turn, passes on in tes preaching of God's word. 1

On the other hand, Kung feels it necessury to correct Diem's theses by observing that his colleague falls "in practice" to do justice to particular testimonies in the Canon of the NT, and hence is guilty of "selection as a matter of practice" in contrast with Kasemann's selection as a matter of principle. Küng sees a shortcoming in Diem's approach, particularly in his basic assumption that "early Catholicism" did not start, "especially the teaching office," until well after the NT times and is therefore a "deflection from the Jew Testament." 2 This position, in Kung's view, is difficult to hold if Diem wants "to take the whole of the New Testament serfously." 3 Kung also remarks that kasemann's attftude of declaring the Catholicism of the NT to be un-Evangelical is to be regarded as more convincing than Diem's attitude of simply ignoring or giving minimal interpretation to the Catholic element in the NT.

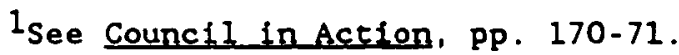

Ibid., pp. $176-77$

I Ibid., p. 180.
} 
Küng's own position regarding the Canon of the NT as contrasted with Diem's and Kasemann's views is revealed in the following:

What is the point on which Diem and Kasemann are... . profoundly in agreement? They agree in not being disposed to understand the NT kath' holou. . . . Their tacit, taken-forgranted a priori position is Protestantism. And what this means is that it is laid down from the outset that within their exegesis and theology there is to be is road towards "Rome." 1

In finding his two Protestant colleagues faulty of selectivity with respect to the NT Canon, ${ }^{2}$ he observes that their selective attitude results from their anti-Roman Catholic "presuppositions." They read the text of the Scriptures with a preconceived bias. Conversely, the correct approach to the NT, for küng, is to be "catholic," to be "open in every direction that the New Testament leaves open: not to exclude, either in principle or in practice, any line that belongs to the New Testament." 3 This position taken by Küng is most significant and raises important questions regarding the normativity of the NT. As stated in his essay, his position means that he is willing to take the NT Canon as canon, 1.e., that he regards the whole collection of NT documents as the standard or norm for Christian orthodoxy. Küng's intention to take the Canon of the NT seriously is to be praised if one belleves that a differenti. atton between crue and faise Christian belief is possible.

I Ibid., p. 181.

${ }^{2}$ Kasemann, through a fundamental choice made in advance, and Diem, through a selection made in practice whenever "Rome" comes in sight (ibid., p. 182).

${ }^{3}$ Ibid; emphasis his. 
Küng's discussion with Kasemann and Diem regarding "early Catholicism" in the NT clearly showed that even though he may be considered "Protestant" to the extent that he underlines the supremacy of the Word of God as witnessed in the Scriptures over the church's magisterfum, he is explfcitly non-Protestant--at least in his own opinion--regarding the hermeneutical approach to the Canon of Scriptures. One more statement from küng may serve to further underline this point:

The disastrous thing in Kasemann's theology is not its adoption of a "central point of Scripture".. . but the Protestant exclusiveness with which it makes this centre into the whole. . . . The disastrous thing in Diem's theology is not that it leaves certain witnesses in the background.. . but the Protestant exclusiveness with which it does not allow certain witnesses to speak at all. 1

Protestant selectivity is, in brief and according to küng, heresy.

The research has made it plain that Küng's leading theological concerns began to take shape between 1953 and 1955. during the last years of his studies in Rome. ${ }^{2}$ Desirous to prepare himself for a pastoral ministry, his concerns were essentially pastoral in nature. They constitute the basic characteristic of his theological career to this point. In fact, two main preoccupations seem to undergird the Swlss author's theological activity: to achieve an ecumenical understanding of all Christianity and to make the Christian message intelligible, meaningful, and relevant to modern-minded men and women. These two concerns have compelled küng to contend with two issues regarded as stumbling blocks for the

$I_{\text {Council in Action, p. } 183 .}$

${ }^{2}$ For this particular matter, see above, pp. 127-35. 
ecumenical movement and for contemporary man. Respectively, they are (I) some inconsistencies, even errors, found in dogmatic pronouncements of the Roman Catholic magisterfum and (2) the church's model of authority which stresses the infallibility of the papal teaching authority. Throughout his prolific literary production. Küng has attempted to work out a solution to these two problems which are directly related to the issue of orthodoxy and heresy.

As far as the principle of authority is concerned, we found that küng not only explicitly affirms acceptance of doctrinal authorfty in the church, but, expresses as well his intention to help this authority to become aware of both the essence of the original Christian message and the requirements of the present generation. 1 Here again his pastoral concerns come clearly into view. In advocating a return to the original sources ${ }^{2}$ of Christian tradition, he is appealing to what every Christian should recognize as authoritative. ${ }^{3}$ In this way his ecumenical concern comes to 1ight. He also wishes to remove every element that may preclude the credibility of the church's proclamation in the modern world. The

IJosé Gomez observes that "in the case of Hans Küng's theology the main emphasis is on the origins of Christianlty, the second on the reality lived by the bellevers today and only the third on doctrinal tradition" ( $J$. Gomez Caffarena, "A Summa for People of Today," in W\&W, F. 118).

2 see, for instance, "New Consens.1s," p. 3.

3 Wilken remarks that "few Christians would deny that the New Testament is the standard by which every later development is to be evaluated" (Wilken, The Myth, p. 21). 
role of scholarly theological research is deemed by küng indispensable for this task.

Significantly enough, the Vatican authorities recognized Küng's pastoral concern and pralsed him for having made the gospel relevant for innumerable contemporaries, but felt it necessary to criticize him for causing perplexity and confusion among the bellevers. ${ }^{2}$

As to the revelational norms of Cnristian doctrine, i.e.. the teaching of the apostles and of the NT Canon, Küng credits both with being the unique, unrepeatable witnesses of God's revelation in Jesus Christ. He tirelessly asserts their normative status for all Christian beliefs and teaching: "The preaching of the apostles, as it has come down to us in the writings of the New Testament, is the original, fundamental testimony of Jesus Christ, valid for all time." 2 He holds that "The criterion determining all norms of Christian theology "can never again be some ecclesiastical or theological tradition or Institution, but only the Gospel, the original Christian message 1tself. ${ }^{3}$

We may conclude therefore that in Kung's position we have an emphasis upon the revelational criterion as expressed in the apostolic and scriptural norms of orthodoxy. In this sense, his

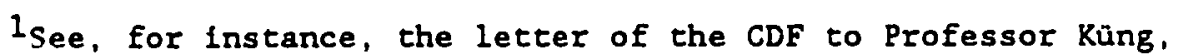
dated March 30, 1974: "In your writings in many languages, in your lectures in various parts of the world, you have continued to disseminate opinions which have deeply confused the faith of the Christian community" (Küng Dialoque, p. 81).

2 Kung. The Church, p. 456.

3 Küng, "New Consensus, " p. 14. 
attitude may be Identified with that of the Reformers of the 16 th century.

The normativity of the Scriptures, however, should not be understood in naive biblicist terms. I While holding that "theology must everywhere be oriented toward the biblical findings," Küng notes that the latter must be "analyzed by historfcal-critical analysis."2 We must consider the implications of this particular point below. ${ }^{3}$

After this brlef analysis of Küng's attitude toward the original sources of Christian doctrine, let us now consider his view regarding the ecclesiastical criterion of orthodoxy and the norms of Christian truth and theological issues related to it which I Identified in the first chapter.

\section{Part Two: on the Princioles. Norms and Issues Related to the Ecclestastical Criterion of Orthodoxy-Heresy}

The historical-theological analysis of the development of classical orthodoxy in chapter 1 showed that, from the beginning, all Christian parties claimed to base their teaching upon authority; specifically, on the authority of the revealed message of God as expressed in the teaching of the apostles and in the NT canon as norms of orthodoxy. ${ }^{4}$ with the passing of time, however, and due to

\footnotetext{
$l_{\text {Küng, Infallible?, p. } 210 .}$

2 "New Consensus, " p. 14.

${ }^{3}$ See chapter 5 .

${ }^{4}$ See above, pp. 31-37.
} 
the increasing struggles between the various Christian parties, 1 all of which claimed allegiance to the doctrine of the apostles, a more specific norm for securing the continuity of the Christian teaching through a faithful tradition ${ }^{2}$ became much needed. The emergence of the princlple that the living tradition existed permanently through an uninterrupted succession within the ecclesia was established eventually as the main criterion of orthodoxy. ${ }^{3}$

Indeed, tradition is not a side issue for the kerygmatic dimension of the church's mission. In the first chapter I affirmed that there is need to realize that Christianity cannot exist in its Histurical dimeasion without tradition. ${ }^{4}$ The Christ event is so

1oward the second half of the second century those struggles took place mostly between the varlous Gnostic parties and what began to be called Cathollc Christianity.

2We must recall here what was underlined in chapter 1 regarding the technical meaning of "tradition." The basic idea expressed by the term is that of "transmission, "the handing down of the message that the Lord committed to the apostles. The term implies, therefore, two things: (1) the handing down of the wessage and (2) the message itself. In other words, when somebody speaks of "tradition," he or she may be referring either to the process of transmission of the message or to its content, or to both. From a historical perspective, it must be noted that the early fathers usually meant by tradition the passing on of Christ's teaching, either orally or through documents, including the canonical ones. It was much later (definitely since the Council of Trent) that "tradition" came to denote more specifically unwritten doctrine-then crystallized in creeds and dogmas--in contradistinction from the Scriptures. This is the sense in which "tradition" is generally understood in Catholic and Protestant circles nowadays (see above, pp. 55-59). orthodoxy."

${ }^{3}$ I have labeled this the "ecclesiastical criterion of ${ }^{4}$ See above, p. 51, n. 1. 
central for the Christian religion, 1 that it must be preserved in the memory and communicated to human beings through all ages till the consummation of God's plan of redemption.

From the perspective of the orthodoxy-heresy antithesis, the issue remains, however: How are we to distinguish between true and false tradition? As can be Inferred from the biblical cestimony, this issue is not of secondary importance for the task and mission of the church. More specifically, since the formulation of Christian doctrines has undeniably been changing with the passing of the centuries, ${ }^{2}$ it would seem that the idea of an "uninterrupted tradition" does not necessarlly mean "unchanged tradition." The specific theological issue which arises in this connection, and which is directly related to the orthodoxy-heresy antithesis, is the one of continui-y-and-change in Christian theology. of particular importance is the dilemma of distinguishing between legitimate development of doctrine and adulteration of the original faith. ${ }^{3}$

With these issues in mind, my intent in this part of chapter 3 Is to describe and analyze Kung's understanding of the constitutive elements of the orthodoxy-heresy structure which I have listed

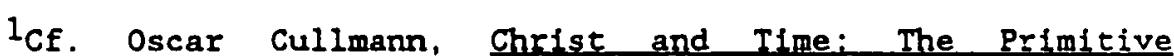
Christian Conception of Time and History, trans. Floyd V. Filson (Philadelphia: Westminster Press, 1950), Pp. 121-30.

Among the central beliefs of Christians are the notions that in Jesus Christ God was revealing himself to humankind; in Christ. God was reconciling the world to himself; through Christ's life, death, and resurrection, God was definitely overcoming evil and death, and thus bringing salvation to human beings.

${ }^{2}$ See my reference to this matter in chapter 1 , pp. 84-85, especially p. 85, nn. 2 and 3 .

${ }^{3}$ see above, PP. $85-96$. 
in the category of the ecclesiastical continuity of the Christian doctrine, namely, the principle of succession-tradition, and the ecciesiastical criterion expressed in the oral traditions of the church as well as in the pronouncements of the Magisterium as norms of orthodoxy. The theological issue concerning the unity of the church's doctrine also needs attention.

In the overall context of the ecclesiastical criterion of orthodoxy, I focus my attention, first, on Küng's position regarding the principle of tradition.

The Principle of Succession-Tradition

In analyzing Küng's position on the authority of the ecclesiastical tradition, one should be aware of the fact, ds LaCugna already observed, that küng lacks a clear definition of the term tradition itself. ${ }^{1}$ still, various statements make clear enough that he is generally thinking of tradition in terms of the definitions of Trent and Vatican II. Tradition is the authoritative teaching of the church in contradistinction from the text of the Scriptures. Thus, as early as 1957, Küng could write that the Roman Catholic Church never taught that "tradition like Sacred Scripture could claim divine inspiration." 2 He further differentiates tradition from Holy Scripture, claiming that the Catholic Church has always taught that

Even the most important documents of tradition such as infallible papal and conciliar definitions... . still

1LaCugna, Methodology of küng, p. 96.

${ }^{2}$ Küng, Justification, p. 111. 
constitute no more than a human account of divine revelation (see also $D$ 1800). So there is this vital difference between any--even the most exalted--document of tradition and a text from Sacred Scripture. 1

Since LaCugna has already shown, in my view correctly, that in Küng's theological methodology tradition is tha üurma normata in contrast to the norma normans which is scripture, 2 a brief retlection on some reprecontative statements of kūng should suffice here.

There is little doubt, to begin with, that Hans küng appreciates the value of tradition--in the technical sense of transmission of the Christlan message--for the task of ascertaining true Christian belief and teaching (orthodoxy). He explicitly describes tradition, understood in this sense, as one of the main "criterla of Christian truth. "3

As for tradition in the modern Roman Catholic sense, that is to say, that part of the Christian teaching which is not the Scriptures, 4 kūng holds that its normative value is only derived

IIbid. It is true that in Justification, which belongs to Küng's "pre-criticism" epoch, it is his view of the Scriptures which puts them above all "human" writings. In his "post-criticism" volumes he still differentiates between both norms. See, for instance, The Church, p. 528: "Often, instead of referring to the original testimony of Scripture, reference was made to 'tradition,' to 'the Fathers.' whether Greek or Latin, old or new." See also Infallible?: p. 49, where writing about Pope Paul VI's encyclical Hupanae vitae, Küng observes that in this document "papal tradicion" counts for more than "Scripture."

2Lacugna, Methodology of Küng, pp. 95-125. See, for instance, Küng, The Church, p. 36 passim.

${ }^{3}$ The Church, pp. $39-46$.

${ }^{4}$ See Vatican II Constitution on Divine Revelation, arts. 9 and 10 . 
from the superior normativity of the scriptures. In this specific sense, tradition possesses a "sacondary standardized authority by comparison with the original, primary standacdizing acthotity af the gospel and Jesus Christ himself who is attested there." 1

Küng explicitly states that he is well aware of the accusation which some Protestant theologians, Karl Barth among others, direct at the Koman Catholic Church, namely, that it has not recognized the Scriptures as a unique and fundamental authorlty, but has added to it its own "ecclesiastical tradition." 2

At Trent, runs the accusation, "tradition ousted Scripture, at Vatican I real historical tradition was in turn ousted by the present magisterium of the Church." 3 While Küng has been prompt to denounce the frequent reference of the Catholic Church to tradition and to the Fathers--"who were often chosen quite arbitrarily and still more arbitrarlly quoted"4.-rather than to the original testimony of the Scriptures, ${ }^{5}$ he also condemns the opposite extreme, namely, the "Protestant radicalism"--not to be confused with "evangelical radicality," Küng remarks--which wants unhistorically to pass in a great leap over the Middle Ages to Luther and Calvin,

I Ibid., p. 43; emphasis is Küng's.

2 See Küng. The Church, p. 311.

3 Ibid.

4 Ibid., P. 528 .

${ }^{5}$ As an example of this method, Küng observes that the teaching of Vatican II on the hierarchical structure of the church (Lumen gentium, chapter III) is not based on the NT but on Vatican I (see Infälible?, p. 79). 
and "from that point to leap across one's own 'orthodox' tradition to the more recent church fathers." 1

Over against the latter attitude küng sets what he cails "catholicity in time." 2 The theologian who is truly "Catholic" does not set aside certain centuries as "un-Christian" or "unevangelical." He never overlooks the church's tradition, i.e., the creeds and definitions set up in the past to distinguish between good and bad interpretations of the message. Rather, he shows interest "in the continuity which is preserved through all discuptions." 3

In Küng's understanding of the term, "Catholic." as a basic attitude, means that special importance is attached to "the entire. universal, all-encompassing, total Church." In the concrete, to the "continuity in time" of both falth and the community of faith enduring in all disruptions. 4 This continuity is what "real tradition"5 means, 1.e., the transmission of the Christian message In the entire church. Understood in these terms, tradition is a "valuable guideline for the church, its continuity and its consistency."6 In the process of "discovering Christian truth," both the community and the tradition of the Church "form an

$1_{\text {Küng, Maintained, p. } 81 .}$.

2 Ibid., p. 80.

3 Ibid., p. 81 ; emphasis in the original.

${ }^{4}$ Küng, Christian, p. 503; emphasis his.

5 Küng, The Church, p. 555.

${ }^{6}$ Ibid., p. 610. 
essentlal part."1 This is so, Küng explains, because the Christian message "reached me by way of the believing community and is still lived today in that community." In addition, Küng notes that the Christian message was not devised by the present generation. "It has been handed down through a history of twenty centuries." 2 In this way, the historical tradition and the Christian community can help us to break through the limits of our subjectivity and "to percelve the eruth more deeply and more comprehensively. " 3

We noted above Küng's view of the subordinate role of the oral tradition of the church to the NT Canon, to which he assigns the fundamental place in the definition of Christian belief and teaching. 4 In his words, apart from the teaching of the apostles as ragistared in the NT Canon,

All other testimony in the tradition of the Church, however profound or sublime, can in essence do nothing more than circle round this orlginal testimony of God's inre s.:terpret, commentate, explain and apply the original message according to constantly changing historical situations. 5

Mark the twofold assertion made by Küng, namely, the normative and programmatical nature of the NT Canon for all

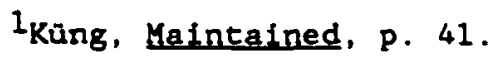

2 Ibid.

${ }^{3}$ Ibid.

${ }^{4}$ See above, pp. 178ff. As for the normativity of the teaching of the apostles, Kung remarks that the office of the apostles having temporal and authoritative precedence over the succeeding office in the church, the latter "can only preserve and interpret" the original witness and proclamation of the apostles (see structures, p. 177).

${ }^{5}$ Kung, The Church, p. 36 . 
subsequent Christian theology, and the necessity of a historical translation and application of that norm. Because of their importance, these two dimensions, as in Küng's view, namely, the original point of reference for all Christian tradition and the historical dynamism of the latter, deserve further comment.

The original point of reference for Christian tradition

Küng clearly realizes that all variations which are due to "constanty changing historical situations" always must be measured against a definite original point of reference, namely, the witness of the canonical Scriptures. Making explicit reference to the issue of the criteris and norms of orthodoxy, he affirms that "the critertion for what is supposed to be true in the Christian Church can be nothing but the Christian message." This message, he explains, is the gospel of Jesus Christ "as originally recorded in the New Testament--in writing, naking arbitrary changes and developments impossible." ${ }^{1}$ This means, at bottom, that the criterion and norm for Christian truth is "Jesus Christ himself." 2

In this sense, Kung would not agree without qualification with Robert L. Wilken's proposal that instead of looking at their partfcular "construction of the past," Christians should rather look forward. ${ }^{3}$ As a matter of fact, Wilken specifically questions Küng's

1 Küng, Maintained, p. 40; emphasis his.

2 Ibid.; emphasis in the original.

${ }^{3} R$. L. Wilken, The Myth of Christian Beginnings, p.189 passim. "Instead of viewing the Christian history as a movement away from something--an original perfection--why not view it as a 
position concerning the normativity of an original Christianity. He focuses his critique on the Swiss theologian's concept of the nature of the church, more speciflcally on Küng's statement:

There is a constant factor in the various changing historical images of the Church, something which survives however much the history of mankind, of the Church and of theology may vary, and it is on this that we must concentrate. There are fundamental elements and perspectives in the Church which are not derived from the shurch itself: there is an "essence" which is drawn from the permanently duvisive origins of the Church. 1

The contrast between the positions of Küng and Wilken appears clear on at least two points: (1) the importance for Christian bellef and teaching given by küng to the original witness of the epostles and the NT Canon; and (2) as a corollary, the more "conservative" position of the Swiss theologian.

The historical dynamise of Christian tradition

For all we fust observed, it is indispensable to keep in mind that kung does not simply cling to the normativity of the very text of the Scriptures. That would be a "naive biblicism" which he

movement toward something? Perfection lies if anywhere, not at the beginning, but at the end" (1bid., pp. 192-193; emphasis his. Cf. p. 194). The authority of the apostolic age, Wilken claims, is a theological idea which the Christian tradition, "by a process of selectivity and interpretation has abstracted and segregated . . . and made of it an ideal expression of Christlanity" (ibid., p. 25).

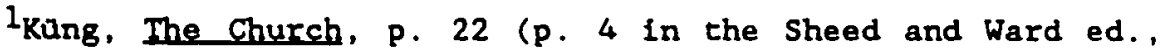
New York, 1967); quoted by Wilken, with a modified wording, in his volume The Myth, Pp. 23-24; emphasis added by Wilken. Cf. Küng, Council in Action, p. 204: "The Church will indeed thus discern and hold fast to the one unchenging Faith under all the various formulas of the various centuries." 
hardly supports. 1 After emphatically affirming thet the criterion for Christian truth is the gospel of Jesus Christ as recorded in the New Testament, Küng explains:

The New Testament . . may not be understood in a biblicist-fundamentalist sense as a collection of infallible statements, but must be given an historical-critical interpretation at the highest level of modern hermeneutics. 2

This is the second point which we need to underline in Küng's position regarding Christlan tradition. In addition to his stressing the normativity of the original point of reference (i.e., the Canon) for all Christian tradition, we need to consider his notion of the historically conditioned nature of all the statements of falth and doctrines of the church, including those of the NT Canon. ${ }^{3}$ The original message must be interpreted, explained, and applied in accordance "with the constantly changing historical situations."

It is in these changing historical contexts, precisely, that Küng sees the main reason for the relativity and flextbility of the church's theological formulations and for his rejection of the

Isee Infallible?, p. 210: Identifying "biblicism" with the Ideas of the verbal inspiration and inerrancy of the text of Scripture, Küng holds that "Biblicism has remained a constant danger for Evangelical theology, and the idea of a verbal inspiration has been upheld, not only in numerous sects, but also in some Protestant Thurches, particularly in modern American fundamentalism, and in some trends of European pietism. The Christian message, Christ himself as preached, is no longer the real ground of faith, but the infallible word of the Bible as such."

${ }^{2}$ Küng, Maintained, p. 40.

${ }^{3}$ As we discuss further below, the historically conditioned nature which küng ascribes to tradition must also be seen in the biblical material. 
notion of infallible propositional teaching, 1 including the text of the Scriptures.

The issue of continuity-and-change

in Christian doctrine

The unchangeable essence of Chrlstian teaching and Its historically conditioned nature clearly stand in tension. Küng's view on this tension already appears in his concept of the nature of the church, which we might regard as a test case for his position on the issue of change-and-continuity.

As already noticed, Küng holds that there is a "constant factor," an "essence," something which survives in the historical forms of the church however much its history may vary. 2 Rather than explicitly explaining what this essence amounts to, he remarks that this constant factor is only revealed in change. 3 "The 'essence' of the Church is not a matter of metaphysical stasis, but exists only in constantly changing historlcal 'forms'. "4

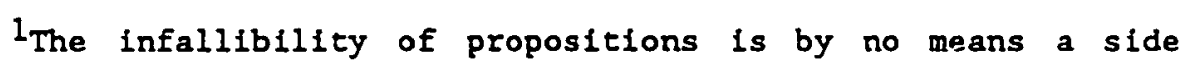
issue in Küng's writings. It is addressed below. pp. 288-98.

${ }^{2}$ See Küng, The Church, p. 22 .

$3^{n}$ The essence of the Church is therefore always to be found In its historical form, and the historical form must always be understood in the light of and with reference to the essence" (1bid., p. 24). Conslder also the following remarks: "Loyalty to its original nature is something the Church must preserve through all the changing history of that world for the sake of which the Church exists. But it can only do that through change (aggiornamento), not through immobility (immobilismo)" (ibid., pp. 34-35). "If the Church wants to remain true to its nature, it cannot simply preserve its past" (ibid., p. 46).

${ }^{4}$ Ib1d., p. 23. 
Küng points out that this original and permanent "essence" is "something dynamic rather than something static and rigid." 1 The reason for this is that essence and historical form cannot be separated ${ }^{2}$ though they may not be regarded as identical. ${ }^{3}$ How else, asks he, can we establish a criterion, a norm, which will enable us to decide what is legitimate in any historical and empirical manifestation of the Church?

From this perspective, and quite significant for our understanding of Küng's notion of continuity-and-change seen in the overall context of the orthodoxy-heresy antithesis, is küng's view regarding "errors and false developments" in the history of the church. ${ }^{4}$ It is the essence which provides the "norm which will enable us to decide what is legitimate" in the historical development of the church. ${ }^{5}$ This indeed is necessary, Küng thinks, since in his eyes "not all the subsequent developments in the Church can be authorized by its origins" as recorded in the New Testament. ${ }^{6}$

I Ibid.

2 "The distinction between essence and form is a conceptual, not a real, distinction. There is not and never was, in fact, an essence of the Church by itself, separate, chemically pure, distilled from the stream of historical forms" (ib/d.).

3"The essince and the form of the Church should not be equated, but must be recognized and distinguished. Even if the distinction between essence and form is a conceptual one, it is none the less necessary" (1bid., p. 24).

$$
\begin{aligned}
& { }^{4} \text { Ibid., p. } 46 . \\
& { }^{5} \text { Ibid., p. } 24 . \\
& { }^{6} \text { Ibid., p. } 46 .
\end{aligned}
$$


By implication, all doctrinal statements of the church's tradition should be open to correction due to their human limitations. As early as 1962 Küng addressed the issue, which he was to discuss later in a more detailed way in Infallible? (1970), of the historically conditioned nature of dogmas and of the limitation of every human statement of truth. 1

Doctrinal statements of the church's Magisterium are, first, "human and historical formulations," observes küng. "Even though they have the assistance of the Holy Spirit,n2 to the extent that they are also human and historically conditioned, it is of their very nature "to be open to correction and to stand in need of sorrection. " 3

Development of dogma, 4 therefore, "is not always necessarily just an organic development," notes he. 5 "It would in any case not be a good thing to suppose that the fact that a dogma has been defined necessarily means that a blossoming of faith has come

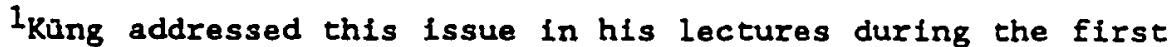
session of Vartcan II. They are published in Council in Action. Pp. 196-208, under the title "Why Are Dogmatic Pronouncements So Difficult to Make Today?"

2 The CDF, in a letter addressed to küng on March 30, 1974. states: "The Catholic Church belleves (see Vatican I) that, due to the assistance of the Holy Spirit, these presuppositions (on which infal-libility rests] exclude the possibility of any error in a dogmatic definition (cf. Misterium Ecclesiae, 5)." Küng Dialogue, p. 82 .

${ }^{3}$ Küng, Council in Action, p. 205; emphasis his.

${ }^{4}$ On the main interpretations of development of dogma, see above, pp. $88-96$.

5Ibid. On the "organic" theory of development of dogma, see above, Pp. $88-91$. 
about."I This view clearly counters the official Roman Catholic notion of dogma. 2 To nobody's surprise the Congregation for the Doctrine of the Falth specifically questioned küng for apparenty assuming that "the doctrines you advocate were all material for free theological discussion and did not touch upon any truth binding on a believing Catholic." 3 The Corgregation stated unequivocally that the questions our author was raising in his books and in a previous letter ${ }^{4}$ dealt indeed with Catholic dogma and, therefore, were not matter of "free theological discussion." 5

Conversely, Küng understands dogmas as being

nothing more or less than emergency measures to which the Church is driven by heresies. . . . Thus, one characteristic of dogma is its polemical orientation. . . . The church, faced with the incursions of heresy, is soncentratiols on quite definite points, illuminating certain aspects more and hence others necessarily less. 6

Almed at counteracting specific heresies, the church's
dogmas are by definition historically conditioned. It is therefore
quite possible that in its dcgmatical definitions, the Magisterium

I Ib1d., p. 205; emphasis in the original.

2 For reference to the official Roman Catholic teaching on "dogma," see above, p. 93, n. 2, and p. 162, n. 4. Commenting on that notion, Karl Rahner points out that the decisive characteristics of dogma are divine origin, truth, the obligation to believe it, and tmmutability, among others (Rahner, "Dogma: Theological Meaning," SM [1968], 2:96).

${ }^{3}$ See Küng Dialogue, p. 83.

${ }^{4}$ Kung's to the CDF, dated september 22, 1973. For the complete text of this letter, see kung Dialogue, pp. 69-77.

5 Kung Dialogue, p. 82 .

${ }^{6}$ Küng, Councti in Action, p. 205; emphasis his. 
may indeed leave out some aspects of truth. Likewise, in its condemnation of error it may also find itself attacking "the core of truth" that always exists in error. 1

Moreover, heresy, which in Küng's concept is one-sidedness, selectivity, concentration on a particular dimension of truth, ${ }^{2}$ obliges the church to likewise concentrate on definite points. Truth, according to küng, is neither in the heretical position, nor necessarily or totally in the dogma which counteracts it, but in the balance which sets "the original tension in unity." Herein lies the great task of theology and of the church's teaching authority, according to Küng. 3

It should be noticed that Küng's concern for the contradictions, even errors, detectable without much difficulty in the corpus of his church's tradition, is related to his pastoral preoccupation for making it a more credible sign of the kingdom of God in the contemporary world. A church which is willing to admit its errors is more respected, thinks Küng, and prompts a better attitude among those who must be reached by its proclamation. Besides, Küng's second main pastoral concern, namely the ecumenical dimension of Christianity, may be seen behind his unhesitant calling attention to the fact that Roman Catholicism has been, in his view, at times

1 Ibid., p. 207. As noted below, this idea is further developed by küng in Infallible?.

25ee, for instance, Council in Action, p. 172; Theologie im Aufbruch, p. 98 .

${ }^{3}$ Council in Action, p. 205. Küng's concept of truth is addressed in more detail below, pp. 274-315. 
unfaithful to the gospel. Hence his untiring call to return to the original sources of Christianlty.

It is Kung's concern for truth, on the other hand, which has led him to stress the subordinate role of the church's oral tradition as a norm of orthodoxy. The fact that in its dogmatic definitions the Magisterium has left soma aspects of truth in shadow, and that in its condemnetion of error it may also have found itself attacking "the core of truth" that always exists in error, has compelled küng to look for a theorical solution to the impasse. His solution consists presisaly in underlining both the subordinate and historfcally conditioned nature of the church's tradition, facts that naturally call for constant revision of the formulas of faith.

The Normativity of the Magisterium's Pronouncements

Thus far, in the overall context of the ecclesiastical criterion of orthodoxy we have focused our attention on Küng's views concerning the principle of tradition as such and in the oral tradition of the church as a concrete norm of authentic Christian doctrine. The time has come to consider the Swiss theologian's thougitit Iegarding the normativity of the magisterial p=onouncements of the church.

Since Jesus did charge his disciples with the responsibility of setting forth his teachings through the centurles (Mark 16:15; Matt 28:18-20), this mission is accomplished by the church's proclamation and teaching. Yet, where is this teaching authority specifically to be found and how does it function? Before analyzing 
Küng's position, let us consider the Roman Catholic answer to these questions.

According to Karl Rahner, 1 the teaching authorlty of the church in Roman Cathollcism is described and defined "in its fullest and most authentic form" in the third chapter ${ }^{2}$ of the Second Vatican Council's Dogmatic Constitution on the Church (Lumen gentium), more particularly articles 24 and 25.3 Given the significance of this

1See Rahner, "Magisterium," Sacramentium Mundi (1969), 3:353.

${ }^{2}$ Avery Dulles observes that "the most important doctrinal achievements of Lumen Gentium are contained in the third and longest chapter, dealing with the hierarchy." He remarks that the Eonstitution on the Church, in turn, "because of its central importance and its wealth of doctrine, probably deserves to be called the most imposing achlevement of Vatican II" ("The Church," in Docs. of Vatican II, ed. W. M. Abbott, Pp. 12, 13).

${ }^{3}$ Among the numerous commentaries on the Constitution lumen gentium, and in particular on articles 24 and 25 , the following ones are helpful: Karl Rahner, "The Hierarchical Structure of the Church, with Special Reference to the Episcopate-Articles 18-27." trans. Kevin Smyth, in Commentary on the Documents of Vatican II, 5 vols., ed. Herbert Vorgrimler (London: Burns Oates; New York: Herder and Herder, 1967), i:186-218; Avery Dulles, "The Church," in The Documents of Vatican II, W. M. Abbott, ed., Pp. 9-13, 46-50; Albert C. Outler, "A Response," in ibid., pp. 102-106; Carlo Colombo, "The Hierarchical structure of the Church," in Vatican II. An Interfaith Appraisal: International Theolegical Conference. University of Notre Dame: Harci $20-26,1966$, ed. John H. Miller (Notre Dame: University of Notre Dame Press, 1966), Pp. 208-218; Gregory Baum, "Commentary," in "De Ecclesia:" The Constitution on the Ghurch of the Vatican Counc1l II, ed. Edward H. Peters, (Glen Rock, New Jersey: Paulist Press, 1965), pp. 31-39; Cornelius Williams, "The Church Is Hierarchical, Commentary on Chapter Three," in Vatican II on The Church, 2d ed., ed. Austin Flannery (Dublin: Scepter Books, 1967), PP. 46-61; Seamus Ryan, "The Hierarchical Structure of the Church," in Vattcan II: The Constitution on the Church: A Theologigal and Pastoral Commentary, ed. Kevin McNamara (Chicago: Franciscan Herald Press, 1968), PP. 199-211; Boaventura Kloppenburg. The Ecclestology of Vatican II, trans. Matthew J. O'Connell (Chicago: Franciscan Herald Press, 1974), Pp. 169-217; Yves M.-J. Congar, Le Concile au jour le jour: trolstème session (Paris: Les Éditions du Cerf, 1965). PP. 36-48; Plerre Hégy, L'autorité dans le catholiclsme contemporain. du Syllabus a Vatican II, Théologie Historfque 30 (Paris: 
teaching for the major issue raised in this dissertation, it has seemed important to quote extensive portions of these articles ${ }^{1}$ while underlining briefly some of their most relevant aspects.

Regarding the question as to where is the ceaching authority specifically found, after addressing the relationship between the bishops and the apostles as well as the nature of the episcopacy (In particular its collegiallity ${ }^{2}$ and the sacramental nature of the episcopacy and the episcopal consecration ${ }^{3}$ ), the third chapter of

Éditions Beauchesne, 1975), pp. 164-195; Vittorio Subilia, La nouva cattolicita del Cattolicesimo: Una valutazione protestante del Concillo Vaticano If (Torino: Editrice Claudiana, 1967), pp. 12-36.

$1_{\text {Article }} 24$ is quoted in full below, p. $220, n .2$.

2 nJust as, by the Lord's will, st. Peter and the other apostles constituted one apostolic college, so in a simflar way the Roman Pontiff as the successor of Peter, and the bishops as the successors of the npostles are joined together" (art. 22). This is "the chief doctrinal point of the chapter," notes Dulles, namely, that "all bishops who are united to the pope and to their fellow blshops by the hierarchical communion. . . constitute a collegial body enfoying supreme power in governing the Church" (Docs. of Vatican II, p. 42, n. 96). Dulles also expressed the bellef that "In the coming years we shall doubtless see many practical applications of this doctrine of collegiality" (1bid.).

${ }^{3}$ In Roman Catholicism, the sacramental character of the episcopacy underlines a special outpouring of the Holy Spirit granted to the twelve apostles as a special college within the church. This spirftual charism is belleved to be passed on mystically by means of the external sign of the imposition of hands In the episcopal consecration. In this way "the fullness of the sacraments of Orders" is conferred only to the bishops (see Lumen gentium, art. 21). Avery Dulles observes that "the Council teaches that the bishop is not fust a priest with greater powers of jurisdiction, but that he recelves through sacramental consecration the fullness of the power of orders" (Docs, of Vatican II, p. $41, n$. 90). In fact, article 21 states that the spiritual gift with which Christ enriched the apostles, "they passed on to their helpers by the imposition of hands...., and it has been transmitted down to us in episcopal consecration." 
Lumen gentium states in its 24 th articlel that the reaching authority of the Roman Catholic Church is found in the college of the bishops as successors of the apostles. This authorfty to teach was given to the apostles and to their successors bv Christ himself. 2 The Council Fathers ceach in the same article that the "canonical mission" or mission to teach and preach has universal validity. In other words, all nations anc every incividiual are to Iisten to the Magisterium in order to reach salvation. As for the power to exercise this teaching authority, it is believed to be granted through the assistance of the Holy spirit. The teaching authority of the episcopal Magisterlum is thus a true service to the

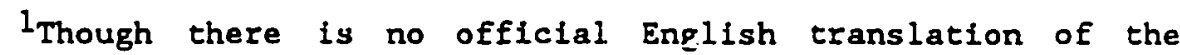
documents of the Second Vatican Council (see Joseph Gallagher, "Preface to the Translation," in Docs of Vatican II, ed. W. M. Abbott, $p$. ix), Abbott's edition is considered the most authoritative. Its text is the one quoted in this chapter.

${ }^{2}$ The 24 th article of Lumen gentium teaches: "To the Lord was given all power in heaven and on earth. As successors of the apostles, bishops receive from $\mathrm{H}$ Im the mission to teach 211 rations and to preach the gospel to every creature, so that all men may attain to salvation by faith, baptism, and the fulfillment of the commandments (cf. Mt. 28:18; MK. 16:15-16; Acts 26:17f.). To fulfill this mission, Christ the Lord promised the Holy spirit to the apostles, and on Pentecost day sent the Spirti from heaven. By His power they were to be witnesses to Christ before the nations and peoples and kings, even to the ends of the earth (cf. Acts $1: 8 ; 2: 1$ ff.; 9:15). Now, that duty, which the Lord comitted to the shepherds of His people, is a true service, and in sacred literature is significantly called diakonia or ministry (cf. Acts 1:17, 25; $21: 19$; Rom. 11:13: 1 Tim. 1:12).

"The canonical mission of bishops can come about by legitimate customs which have not been revoked by the supreme and universal authority of the Church, or by laws made or recognized by the same authority, or directly through the successor of Peter himself. If the latter refuses or denies apostolic communion, a bishop cannot assume office." 
believers. Finally, the conciliar dccument under analysis ${ }^{1}$ holds that the authority of the successor of Peter is above that of the rest of the bishops. ${ }^{2}$

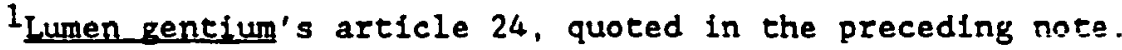

2 Dulles notes that the normal procedure in the Latin Church is that a bishop is assigned to a particular task or diocese by the positive activity of the Pope, even though the Counc:1 here makes it clear that this need not in every case be so (Docs, of Vatican II, F. 47, n. 116).

For a more detalled study of this article of Lumen gentium as well as of art. 25 and the whole third chapter of this Dogmatic Constitution, a number of works, in addition to the commentaries already suggested, can be consulted. They represent both the Roman Catholic and Protestant perspectives. Among Catholic works see, for instance, Floyd Andersen, ed., Council Daybook: Vatican II. (Sessions 1 through 4), 3 vols. (Washington, D.C.: National Catholic Welfare Conference, 1965-66), especially 2:55-58, 309-42; Guilherme Baraúa and Yves M. -J. Congar, eds., L'Église de Vatican II. Études autour de la Constitution conciliatre sur l'Élise, 3 vols. (Paris: Les Éditions du Cerf, 1966-67), 3:723-1009, [see especially articles hy Joseph Ratzinger, Umberto Bett1, and Joseph Lécuyer]; Alexandre Ganoczy, Calvin et Vatican II: L'Église servante (Paris: Les Éditions du Cerf, 1968), pp. 98-100, 111-126, 142-160; Christopher Hollis, The Achlevements of Vatican II. Twentieth Century Encyclopedia of Catholicism, vol. 1 (New York: Hawthorn Books, 1967), PP. 56-81; Peter Kramer, Dienst und Vollmacht in der Kirche: Elne rechtstheoloaische Untersuchune zur Sacra Potestas-Lehre des II. Vatikanischen Konzils, Trierer Theologische Studien 28 (Trier: Paulinus-Verlag, 1973); Otto Karrer, Das zweite Vatikanische Konzil: Reflextonen zu seiner geschtchtlichen und geistifchen Wirklichkeit (Munich: Kösel-Verlag, 1966), pp. 145-191; René Laurentin, Bilan du concile Vatican II. Histolre textes, commentalres (Parls: Editions du Seufl, 1967), pp. 61-75; Gustave Martelet, Les idées maltresses de Vatican II. Initiation l'esportt du Concile (Paris: Desclée De Brouwer, 1969), pp. 28-39; Karl Rahner, Theological Investigations: Volume VI Concerning Vatican Councll LI, trans. Karl-H. and Bonlface Kruger (Baltimore: Helicon Press; London: Darton, Longman \& Todd, 1969), pp. 313-360; Peter J. Riga, The Church Renewed (New York: Sheed and Ward, 1966), pp. 136-176; Xavier Rynne, Vatican Counc11 II (New York: Farrar, Straus and Giroux, 1968), pP. 285-95, 313-22, 405-15; Eduard Schillebeeckx, The Real Achievement of Vattcan II, trans. H. J. J. Vaughan (New York: Herder and Herder, 1967). Pp. 29-32; Catholic Bishops of the United States, The Church in Our Day: A Collective Pastoral of the Amerfican Hierarchy on the Mystery of the Church, on Her Nature and Function. Prepared in the Light of the Dogmatic Constitution on the Church Adopted by Vacican Council II (Washingron, D.C.: United States Catholic Conference, 
For the purpose of answering the second question, namely. how does the church's teaching authorlty function? ${ }^{1}$ it is sufficlent to address now the content of the first part of article 25 in the same brlef, sketchy manner.

Discussing the relationship that exists between bishops and the Roman Pontiff in the exercise of their magisterium, article 25 explains ${ }^{2}$ that the bishops' teaching must be done in communion with

1968); Cardinal Karol Wojtyla (Pope John Paul II), Sources of Renewal: The Implementation of the Second Vatican Counc11, trans. $P$. S. Falla (San Francisco: Harper \& Row, Publishers, 1979), pp. 14654.

Among Protestant works see, for instance, G. C. Berkouwer, The Second Vatican Council and the New Catholicism, trans. Lewis B. Smedes (Grand Rapids, Michigan: Wm. B. Eerdmans Publ. Co., 1965), Pp. 146-77; Jean Bosc, "La Constitution dogmatique Lumen Gentium," in J. Bosc et al. Points de vue de théoloriens protestants: Etudes sur les décrets du Concile Vatican II, Unam Sanctam 64, Préface par le Cardinsi J.-M. Martin (Parls: Les Éditlons du Cerf, 1967), Pp. 15-46; Wolfgang Dietzfelbinger, "The Council Continues: Third Session," In George A. Lindbeck, ed., Dlalorue on the Way: Protes: tants Report from Rome on the Vatican Councll (Minneapolis: Augsburg Publishing House, 1965), Pp. 72-94; Kristen E. Skydsgaard, "The Church as Mystery and as People of God," in Ibld., Pp. 145-74. Concerning the Second Vatican Council in general, see kobert McAfee Brown, Observer in Rome: A Protestant Report on the Vatican Council (Garden City, New Ycrk: Doubleday, 1964); Oscar Cullmann, Vatican Counc11. II. The New Direction, ed. James D. Hester, Religious Perspectives iy (Niew York, Evanston, and London: Harper \& Row, 1968); John Moorman, Vatican Observed: An Anglican Impression of Vatican II (London: Darton, Longman \& Todd, 1967); Warren A. Quanbeck, ed., Challenge, , and Response: A Protestant Perspective of the Vatican Council (Minneapolis: Augsburg Publishing House, 1966).

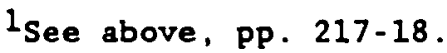

${ }^{2}$ Article 25 reads: "Among the principal duties of bishops, the preaching of the Gospel occuples an eminent place. For bishops are preachers of the faith who lead new disciples to Christ. They are authentic teachers, that is, teachers endowed with the authority of Christ, who preach to the people committed to them the faith they must believe and put into practice. By the light of the Holy Spirit they make the faith clear, bringing forth from the treasury of revelation new things and old (cf. Mt. 13, 52), making faith bear 
the Roman Pontiff, who holds the supreme magisterium. 1 Not only is the preaching and teaching of the gospel one of the most important among the bishops duties, but the latter are the authentic ${ }^{2}$ teachers ${ }^{3}$ since they are endowed with the authority of Christ. They have not received their authorlty in a juridical way from other bishops, but in a mystical way from Christ himself. ${ }^{4}$ The faith that

fruit and vigilantly warding off any errors which threaten their flock (cf. 2 Tim $4: 1-4$ ).

"Bishops, teaching in communion with the Roman Pontiff, are to be respected by all as witnesses to divine and Catholic truth. In matters of faith and morals, the blshops speak in the name of Christ and the faithful are to accept their teaching and adhere to it with a religious assent of soul. This religious submission of will and of mind must be shown in a special way to the authentic teaching authority of the Roman Pontiff, even when he is not speaking ex cathedra. That is, it must be shown in such a way that his supreme magisterium is acknowledged with reverence, the judgments made by him are sincerely adhered to, according to his manifest mind and will. His mind and will in the matter may be known chiefly either from the character of the documents, from his frequent repetition of the same doctrine, or from his manner of speaking."

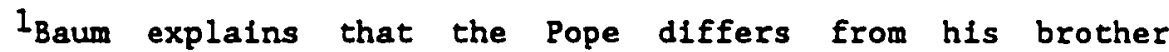
bishops "not sacramentally but only in terms of furisdiction and teaching authority" ("Commentary," p. 34). That the bishops" teaching must be done in communion with the Roman Pontiff is understood if we consider that sacramentally he remains inseparably a member of the eplscopal college of which he is the head, having universal jurisdiction.

2 Sullivan observes (Hagistertum, p. 27) that the translation of authenticum as "authentic" is unfortunate, because the English term in Its modern usage means "genuine," whereas the correct meaning of the Latin word is "authoritative."

$3^{3}$ Having completed its discussion of colleglality--Dulles observes--the Council goes on in the next three articles to consider the role of the individual bishop under the three headings of prophetic (Art. 25), priestly (Art. 26), and kingly (Art. 27)" (Docs, of Vatican II, p. 47 , n. 119).

4 "How are men made into successors of the apostles or members of the episcopal college?," asks Baum ("Commentary," p. 33). Quoting chapter 3 of Lumen gentium. he explains: "A bishop is not a 
belfevers are to belfeve and put into practice is defined by the bishops, and the faithful are expected to submit their minds and wills to the tesching of the episcopai leaders.' In this context, the bishops are entrusted with the responsibility of warding off any error threatening their flock.

Since article 25 goes on teaching matters that concern the specific dimension of infallibility--an issue which I address later in the context of Küng's concept of the Magisterium's Infallibility ${ }^{2}$.. I now pass to consider the Swiss theologian's view on the way in which Christian doctrines are maintained in truth, in contrast with the role that the Roman Catholic Church assigns to the Magisterium for that purpose.

The relationship theologiansMagisterium

As indicated in the sections of the Constitution Lumen Rentium quoted above, ${ }^{3}$ Roman Catholicism regards the bishops, acting

priest who has been elevated to recelve jurisdiction for a new charge but a baptized believer who has received the complete sacramental gift of ministerial ordination." Fnis means that the episcopal ministry in the Catholic Church "is not created by a juridical or legislative act. . . . The episcopal college is therefore a sacramental concept,. . . it is linked to the mysterious structure of the Church" (1bid., p. 34; emphasis in the original).

IDulles stresses the difference between "religtous assent" and "total submission of faith." The first is due to the "noninfalifble teaching of the Pope" and to the individual bishop when he teaches his own flock. The second is due "to the Pope when he speaks ex cathedra" and to "the infallible teaching of the whole college of bishops" (Docs, of Vatican II, p. 47, n. 119).

2 See below, Pp. $290-94$ passim.

${ }^{3}$ See above, p. 220 , n. 2 ; also p. 222 , n. 2 . 
colleglally and in communion with the Roman Pontiff, as the only authoritative (authenticum) teachers in the church. To the bishops are entrusted the functions of sup̃ene viersight, pastoral leadership, and teaching. They serve as "pastors," "administrators," and "theologians." They are both episkopoi and magiscers. 1

As we saw earlier, Hans Küng maintains, for his part, that theology and theologians have a key role in defining the way the church speaks of God. ${ }^{2}$ In holding this view, he came in open contradiction with the official teaching of the Catholic Church and under severe criticism by the Congregation for the Doctrine of the Faith:

1Though the expression "episcopal magisterium" is, according to the Roman catholic concept. redundant (since those who hold teaching authority are the bishops and they alone), we use it to call the attention to the fact that a number of authors, Catholic and non-Catholic, consider that the teaching function is shared by more than strictly the bishops. On this matter, see the articles published by Jürgen Moltmann and Hans Küng, eds., in Concilium 148 (Aug. 1981), Who Has the Say in the Church? (Edinburgh: $T$. \& $T$. Clark; New York: The Seabury Press, 1981).

${ }^{2}$ Küng, Freedom Today, p. 82. Similarly, speaking of the functions of bishops, prophets, and theologians, Avery Dulles observes that "for the prevention of schism and the restoration of unity it is important that pastors, prophets, and theologians be allowed to function with a measure of autonomy and that they be open to correction from one another. Any effort by one ministry to absorb or dominate the others can only aggravate the existing alienations" (Dulles, "Success to apostolorum--Successio prophetarum-Successio doctorum," in Jürgen Moltmann and Hans Küng, eds., Who Has the Say in the Church?, p. 66. Likewise, Yves Congar remarks that, even though the church as the body of Christ has a structure and as such is organized, it is also true that "the whole people of God preserves the Tradition, celebrates and Iives the truth received from the apostles. The whole Church is apostolic. . . It is the whole Church that learns. It is the whole Church that teaches, but in different ways." The New Testament knows "a specific service of teachers, didaskalo1. Theologians continue this service" (Congar, "Towards a Catholic Synthesis," ibid., pp. 70, 71, 74; emphasis his). 
You hold that the concern that comes to expression in your book [Infallible? An Inquiry] is not "to the undoing but to the edification of the Church." . . . Whether or not your doctrines are "to the edification of the Church" does not depend on your intentions. It is a question or fact. It would not be "to the edification of the Church" to contradict defined doctrines of the Church. 1

The issue is clear: dogmas defined authoritatively by the Magisterium are not open for "free theological discussion." 2 The pronouncements of the Magisterium being regarded as the norm of orthodoxy, Roman Catholic theologians are not supposed to contradict ther. At the heart of this controversy between theologians and the eplscopal Magisterium is the question whether the correctness of the church's doctrines is to be defined by the charism of the church's teaching authority or by the scholarly training of theologians, or by a combination of both elements. ${ }^{3}$

In the Declaration Bysterium ecclesiae, ${ }^{4}$ issued by the Congregation for the Doctrine of the Faith on June 24,1973 , precisely against "certain errors of the present day" like those exposed in Kung's books, 5 tha unique doctrinal authority of the

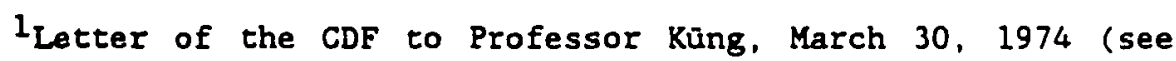
Küng Dialeque, p. 82).

2 IbId.

${ }^{3}$ The issue of Concilium quoted in these pages, namely, who Has the Say in the Ciurch?, is entirely devoted to this controversial matter. Written by Catholics, Protestants and other Christians, these articles are highly recommended as shedding light on this question.

${ }^{4}$ For the complete text of Mysterium ecclesiae, see kung Dialogue, pp. $189-97$.

${ }^{5}$ Though not directly so stated, Mysterium ecclesiae was issued as a response of the Magisterium to Küng. 
bishops is affirmed in the context of "the mystery of the Church," whose priestly office is mystically associated with Christ's perfect priesthood. By means of this priesthood, the zularation continues, bishops and priests are "Indeed set apart in a certain sense in the midst of God's people. . . that they may be totally dedicated to the work for which the Lord has raised them up, "namely, the work of sanctifying, teaching and ruling. ${ }^{1}$ As to the role of theologians, the Declaration affirms that

The due freedom of theologians must always be Iimited by the Word of God as it is faithfully preserved and expounded in the Church and taught and explained by the living Magisterium of the Pastors and especially of the Pastor of the entire Peopie of God. ${ }^{2}$

Here, the task of the theolugians is explicitly subordinated to the authorlty of the episcopal Magisterium. By contrest, kang suggests that the task of the theologians and that of the Magisterium, both at the same level, are under the authorfty of the word of God as witnessed by the apostles and recorded in the scriptures. ${ }^{3}$ In this context, it is the specific mission of trained theologians to be concerned "about the genuineness of tradition and the correct interpretation of the original message" in order to translate it afresh for the church and the world of today. 4

Sti11, Küng notes, it is not rare that pastors do not want to listen to theologians in the church. There may be various

\footnotetext{
I Ibid., pp. 195-96.

Ibid., p. 197.

${ }^{3}$ See Küng Dialogue, pp. 91.92 ; cf. Küng, Ereedom Today, p. 82.

${ }^{4} \mathrm{Küng}$. The Church, p. 554.
} 
reasons, among which their having "litele time for or interest in good theology," or "because in their naivety they suppose they know all the essentials already." It may also be that they do not want their faith "to be disturbed."1 In any event, warns Küng, "a Church in which theologians have to keep silent becomes an untruthful Church. " 2

How significant he considers the role of the theologians in the definition of correct belief and teaching shows in Kung's dealing with the controverifial issues raised by the encyclical Humange vitae. As kung sees 1t, the question arises as to whether the Pope, with the very best intentions, is not taking on "excessive burdens" when in his office of "pastoral proclamation" he wants to study "Iike a theologian," that is, "as a representative of the scientific teaching office, and then to dacide for the whole Church." 3

Differing views on apostolic successton

The role of the theologian, according to küng, is essential for preserving within the church the transmission of the apostolic falth. This seems to take little notice of the Roman Catholic notion of the apostolic succession of the bishops. We fust noticed that Iumen gentiun, for instance, underscores the Catholic belief in

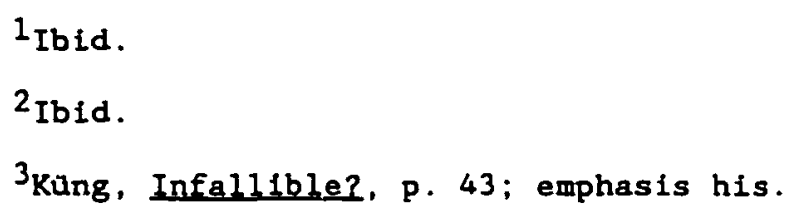


Lie sacramental nature of the episcopal office. 1 This Catholic notion stresses both the "continuous, unbroken replacement of previous incumbents by others who follow them in the same officen 2 and the mystical nature of the authority which bishops inherit. From the perspective of the church, though the theologians may be scholarly fit for accomplishing the role of illuminating the meaning of revealed truths, they lack this mystical and apostolic authority. Kung's view on the apostolic succession was already addressed, in part, in my discussion of his understanding of one of the fundamental components of the orthodoxy-heresy antithesis, namely, the principle of authority. ${ }^{3}$ still, additional consideration of his view, this time from the perspective of the normativity of the Magisterium's pronouncements, further clarifies Küng's position on this subject.

The official Roman Catholic view may be described as stressing the "historicaln4 character of apostollc succession. Conversely, the traditional Protestant position has underlined the "spiritual" character of apostolic succession as "a succession of

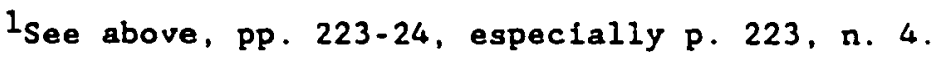

2 Dulles, "Successio apostolorum," p. 64.

${ }^{3}$ See above, pp. 186-87.

4The "historical" dimension of apostolic succesion refers to the uninterrupted transmission of office by direct imposition of hands throughout the history of the church. On the other hand, the "spiritual" dimension of apostolic succession has to do with the transmission of the faith and mission of the apostles, which does not require an uninterrupted chain of ordinations. 
falth." I Though he shares this Protestant insight--which he wishes all Roman Cathollcs could stress more--Küng praised the attitude of the United Lutheran Church of Germany which recognized in its "Declaration Concerning the Apostolic Succession"2 that the relationship of the church to the apostles is not only of a spiritual but also of an historical character, ${ }^{3}$ a view which küng regards as "symptomatic for the whole present development in the ecumene. " 4

The important thing about the Petrine or any other ministry of leadership, however, is not "the historical evidence of a line of succession." 5 What really matters, kung underlines, is succession in spirit, that is, succession in the Petrine "mission and task" as well as in the Petrine "testimony and service." 6

Two facts seem to have led kung to grant particular importance to the spiritual dimension of succession. First, there is a question of practical convenience regarding the spiritual needs of the church. The important thing is not "the chain of succession"

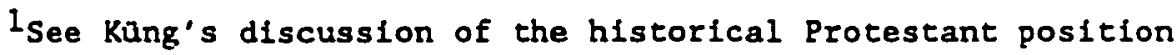
in his Structures, pp. 106-118, $172 \mathrm{ff}$.

2"Erklarung zur Apostolischen Sukzession," issued by the Evangelisch-Lutherischen Kirche Deutschlands in 1957 (see Küng, Structures, p. 170).

${ }^{3}$ For Kün's treatment of this matter as well as his commentary on the United Evangelical "Erklarung zur Apostolischen Sukzession," see his Structures, Pp. 172-212.

${ }^{4}$ Ibld., p. 171.

${ }^{5}$ Küng, Christian, p. 496.

6 Ibid. 
as such, he notes, but "the service ltself concretely realized."I

He explicitly details his point:

To put it concretely, let us suppose that some one could provide irrefutable proof that his predecessor and the latter's predecessor and so on were "successors" of the one Peter, that he could even prove that the predecessor of a long line of his predecessors had been "appointed" by Peter himself as his successor with all his rights and duties. If such a person did not carry out this Petrine mission, did not fulfill his appointed task, did not give testimony or perform his service, what would be the use of the entire "apostolic succession" to him or to the Church? ${ }^{2}$

Un the other hand, continues küng, if a person had difficulty linking his office with the orlginal apostle but lived up to the Petrine mission and fulfilled a task which is an authentic service to the church as described in the scriptures, "would it not then be a secondary--although still important--question whether the 'genealogy' of this authentic servant of the Church was in order?"3 Küng observes that even in the Roman Catholic view, apostolic succession $"$ is all but a mechanical formalism, as it were."4 It is indeed a general Catholic teaching that an "error of the episcopal officeholdcr" is altogether possible, that "even those standing in the line of the apostolic succession can digress from the faith."5 In those cases, obviously, the spiritual dimension of

\footnotetext{
I Ibid., p. 497.

2 Ibid. , p. 496.

${ }^{3}$ Ibid.

${ }^{4}$ Küng, Structures, p. 185.

${ }^{5}$ Ibid. , p. 184 .
} 
apostolic succession has precedence over the historical for determining the validity of office.

The second reason why our theologian puts emphasis on the importance of the spiritual dimension of the apostolic succession is that, as the Lutheran "Declaration Concerning the Apostolic Succession" points out, "up to now no historical proof has been produced of a chain of eplscopal succession." I

Not far apart from the issue of the nature of the apostolic succession and the validity of particular officeholders is the question as to who has the dectsive word in the church.

This question was addressed in a specific issue of Concilium, jolntly edited by Hans küng and Jürgen Moltmann. 2 Küng's view on the matter is concisely oxpressed in the editors' "Foreword." 3 The question of teaching authority, the editors observe, arises with particular sharpness "in the centralistic Roman system with its powerful 'authentic magisterium'." From an ecumenical perspective the question as to "Who has the decisive word in the church?" finds its answer in the belief that "God himself has the say, the declsive word, in the Church." This teaching activity of God is performed through Jesus Christ, who is "the visible word of the Invisibie God." In addition, since the church is the Splrit's living spiritual temple, "It is the Holy Spirit of God and Jesus

I Ibid., p. 182 .

Who Has the Say in the Church? (Edinburgh: T.\& T. Clark; New York: Seabury Press, 1981).

${ }^{3}$ Moltmann and Küng, eds., foreword to who Has the Say in the Church?, Pp. vil-ix. 
Christ that continually leads the Church into the truth and maintains it in the truth. 1

Some Important questions, however, remain. Most of these are addressed in separate articles by various contributors to the same issue of Concilium:

How is what God has to say to the Church through Jesus Christ in the Holy Spirit passed on correctly? In what way is the gospel of Jesus Christ borne witness to in the Church and the world of today in a manner that does justice both to the contents of the message and the times we are living in? What are the structures by means of which the Church is maintained in the truth by the Holy Spirit? ${ }^{2}$

The two fundamental issues they bring up, 1.e., how and by what structures is the truth of the gospel preserved, find a definite answer in küng's writings. They are intimately related to our basic issue of correct bellef and teaching, as well as to the specific matter of the faithful continuity of the Christian doctrine.

In contrast with the historical position which, in the struggle with heresy, led the Catholic Church to virtually equate the notions of "church" and "truth," 3 küng holds a view that questions the a priori acceptance of the correctness of all and every pronouncement of the Magisterium. He is in a sense reversing the movement which changed the emphasis from the authority of revelation to the authority of ecclesiastical definitions. ${ }^{4}$ In this

I Ibid., p. vil.

2Ibid., p. vil; emphasis added.

${ }^{3}$ See above, pp. 65-73.

${ }^{4}$ See above, pp. 62-63. In a trajectory which runs through a 
position, undoubtedly, the factual errors which kung percelves in the history of the church's dogmatic definitions play a fundamental role.

Regarding the question as to how the original gospel is to be faithfully proclaimed today, we have seen so far in this chapter that our author believes that the scholarly labor of theologlans, helped by a modern historical-crltical approach to the text of the Scriptures, is indispensable for assisting the Magisterium in. its labor of correctly explaining the contents of the original witness of the apostolic church to our modern world. In brief, his position may be described as modern and sclentific. 1

As to the second question regarding the structures called to preserve the gospel, Küng sees this magisterial task not IImited to "a few Individuals" in the church's hierarchy but involving the whole body of believers. He claims to be listening to the New Testament's testimony, which, "apart from the pastoral episties," establishes that "it is not the individual officials but the

long and complicated process, this shift of emphasis may be perceived by looking at its two chronological extremes. As can be perceived in the NT Canon as well as in early extra-canonical Christlan literature, the authoritative nature of Christian teaching is affirmed by appealing to the revelational criterion of orthodoxy, which in turn is concretely expressed in the teaching of the apostles and in the canonical scriptures as norms of orthodoxy. On the other hand, in modern times the Roman Catholic Church affirms to be itself the only legitimate bearer and interpreter of the full deposit of faith. In order to affirm the authoritative nature of its teaching, stress is laid on the authority of its own living magisterium.

${ }^{1}$ CE. José Gómez C., "A Summa," in W\&W, p. 116. 
assembled community that has the decisive word to say in matters of doctrine and morals." 1

The Unity of the Doctrines of the Church

The historical-theological outline of the development of classical orthodoxy, in chapter 1 , has shown that in correlation with the increasing importance conferred to the ecclesiastical criterion of orthodoxy--especially the normative character assigned to the pronouncements of the Magisterfum--an emphasis was la1d on the concept of the unity of the church's teaching. It was thought that the teaching of the bishops needed to be unanimous in order to be authoritative. This emphasis, in turn, led to regard all views which differed from the teaching of the majority in the church as false, i.e., heretical, by definition.

Advocating the imperative necessity of preserving the unity of the church, ${ }^{2}$ Bishop Cyprian of Carthage (248-258 A.D.) already argued that this unity was to be found in the unity of the bishops with one another. ${ }^{3}$ The institutional unity of the church was Increasingly seen as the best safeguard against "heresy" (different teaching), a sin which was to be stopped at anj price since it led the church to schism. The argument ran both ways: heresy was to be resisted because it threatened the unity of the church, while church

I Ibid., p. vili. In this view, Kung agrees with the Catholic exegete Bas van Iersel's position expressed in the latter's article, "Who According to the New Testament Has the Say in the Church?," In Moltmann and Küng, eds., who Has the Say?, pp. 11-17.

${ }^{2}$ Cyprian Epistles 75.1,4,5,8 (ANF, 5:397-400).

${ }^{3}$ Cyprian de unitate ecclestae (ANF, 5:421-29). 
unity was necessary to overcome false teaching. Besides, and from a more mundane perspective, from the fourth century on, the Christian emperors regarded Christian unity as an indispensable element of political and social stability.

With the christianization of the Empire and the official status reached by Christianism as the accredited religion of the state, any form of doctrinal diversity in the Christian church came to be regarded as a major crime, to be severely punished not only by the church but by the state as well. In the doctrinal conflicts of the first centuries, settled by means of local synods and ecumenical councils, the winning positions reached the status of orthodoxy. The losing ones were considered heresles in the technical sense of false teaching. As a corollary, the resulting creeds of the church often began to be used as instruments of coercion of Christians by other Christians.

In brief, the notion of the oneness of the church became equated with the idea of uniformity of doctrine. A defined dogma was to be binding everywhere and forever. A defined form of liturgy, a defined ehurch folicy or form of government was to be accepted and practiced universally. The "one" church was the "catholic" church: a church temporally and spacially unified. No dissention was to be tolerated. No regional variety was considered safe. Furthermore, toward the fourth and fifth centuries, it was affirmed that what the officlal church taught in those days sas the very same doctrine of the days of the apostles. Vincent of Lerins gave classical expression to the principle of the uniformity of 
Christian doctrine. True doctrine, he wrote, was that which was believed everywhere, always, by all.

In view of these considerations, it is not strange that in his volume The Church Kung deals with the issue of heresy in the context of the unity of the body of Christ. His position, however, differs from the official teaching of Roman Catholicism on heresy. A brief consideration of this teaching is necessary at this point in order to appreciate more distinctly the mentioned difference.

The Roman Catholic position on heresy

In Canon Law the heretic is defined as a person who after baptism and while retaining the name of Christian, pertinaclously dentes or calls in doubt any one of the truths that have to be believed with divine and Catholic falth. 1 There are some clear Implications here.

$1_{\text {CCL, }} 1963$ can. 1325, \#2 affirms: "One who after baptism, while remaining nominally a Christian, pertinaciously (that is wish conscious and intentional resistance to the authority of God and the Church) denies or doubts any ore of the truths which must be believed de fide divina et catholica, is a heretic; if he falls away entirely from the Christian faith, he is an apostate; finally if he rejects the authority of the Supreme Pontiff or refuses communion with the nembers of the Church who are subject to him, he is a schismatic." Cf. Karl Rahner, On Heresy, trans. W. J. O'Hara (London: Burns \& Oates, 1964), p. 25. Rahner presents a helpfli: discussion of what is "the traditional concept of heresy and the heretic" in the official ecclesiastical sense, in chapter two of this book, pp. 25-40.

The definition of heresy in the revised edition of the Code of Canon Law (CCL, 1983 can. 751) is slightly different in form: "Heresy is the obstinate denial or doubt, after baptism, of a truth which must be belfeved by divine and catholic faith. Apostasy is the total repudiation of the Christian falth. Schism is the withdrawal of submission to the Supreme Pontiff or from communion with the members of the Church subject to him." 
First, only a baptized person can be a heretic. 1 Heresy is a threat to the integrity of the church's faith proceeding from within the church itself.

Likewise, the heretic is a person who regards him or herself as an authentic son or daughter of the church. He or she wants to retain the name of Christian. A heretic is not to be confused with an apostate who denies the faith as a whole and leaves the church.

In addition, error or doubt alone does not constitute heresy since a contumacious, pertinacious will to reject a truth proclaimed by the church (ercor voluntartus) is required.

Finally, "divine and Catholic faith" is understood as the set of truths which are contained in Sacred Scripture and in Tradition, and which have been proposed to the belief of the faithful either by the ordinary magisterium of the church or by a solemn definition.

In this context hans Küng's case seems clearly one of heresy. Not only has he been charged of having departed "from the integral truth of Catholic faith," 2 but he also openly challenges some of the dogmas of the church, among them the infalibility of the church's Magisterium.

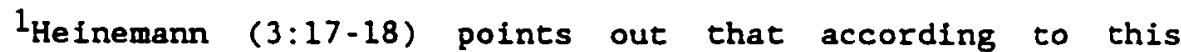
definition, the concept of "heresy" comprises three elements: (1) Only a person who has been baptized can be a heretic: (2) heresy is an error with regard to revealed truth; and (3) one is a heretic who contumaciously wills to remain in error or doubt.

2ndeclaration of the Sacred Congregation for the Doctrine of the Falth," December 15, 1979. See Swidler, Küng in Conflict, pp. $387-88$.
} 
Küng's concept of heresy

Kür.g's most systematic treatment of heresy can be found in his volume The church. 1 Here, the problem of "the church and the heretics" is not addressed in the context of authority or the Magisterium but in the context of the church as the body of Christ, specifically in relation with the unity of the church.

According to the teaching of the NT, Kung writes, "The Church is one body and must be one body." 2 However, the unity of the body of Christ is always endangered. "It is endangered by heresy. "3 küng reminds us that the young church was itself regarded as heretical, a Jewish "heresy," the "sect of the Nazarenes" (Acts $24: 5 ;$ cf. $24: 14 ; 28: 22) .4$ In this case the expression heresy is used "In a neutral sense," meaning school or party, he remarks. Sometimes, however, the term is used in the NT "in a definitely negative sense." 5 In this connection, Küng notes,

Much more starting than the fact that the young Church was regarded as a "heresy" is the fact that from the very beginning there were heresies within the Church. This shows that heresy is not. a chance historical phenomenon, but something that is bound up with the nature of the Church. 6

The existence of heresy within the church is due to the sinful nature of the men and women who form it. The existence of

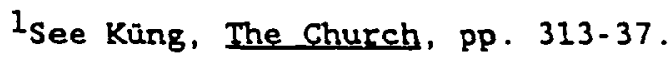

Ibid., p. 313; emphasis his.

${ }^{3}$ Ibid., emphasis in the original.

${ }^{4}$ Ibid., p. 314.

SIbid., p. 315.

${ }^{6}$ Ibid., emphasis in the original. 
heresies must thus be considered a serious challenge for the church. It "cannot simply accept them." I In fact, all through the NT, "from the synoptic gospels to the Johannine letters," we find warnings against false prophets and teachers. ${ }^{2}$

Küng notes that according to the NT, heresy occurs when someone presents "another gospel" (Gal 1:6-9) or preaches "another Jesus" (2 Cor 11:4). In other words, when someone "questions the whole basic faith of the ecclesia." 3

Küng finds the "anti-Church of Marclon" a movement which "is most useful in reaching a definition of what heresy is." 4 Marcion's intent was not on heresy but on reforming the church which, in his view after belng Judaized, ner-jed to rediscover Its orlgins. His heresy was marked by "a radical concentration on the Gospel of Jesus," which led to a "radical reduction along Pauline lines."5 Seeing a sharp contrast between the gospel of Jesus and the Old Testament and its God, Marcion

- . boldly undertook his own biblical criticism, in a spirit of radical Paulinism, and replaced the rejected old Testament by a canon of the New Testament which consisted of the 'Evangelion' . . and the 'Apostolikon'." 6

I Ibid., p. 331 . See also p. 327.

2 Ibid., p. 315 .

3 Ibid.

${ }^{4}$ Ibid., p. 316.

5Ibid. As alredy noted (see above, pp. 191-98), a one-sided reductionism and a selective concentration on one aspect of the content of the NT is, In Kung's view, characteristic of the heretical approach of Protestants to the Canon.

6Ib1d. 
Having been excluded from the Christian communtty in Rome after discussions with the elders. Marcion formed an anti-Church "which in the second and third centuries stretched fram the Euphrates to the Rhone and presented a considerable challenge to the Catholic Church." 1

Taking "this first obvinus heresy" us a basis for deductions about the nature of heresy as such, Küng finds the following points relevant:

(1) A heresy cannot exist solely on the basis of error, or else it would be very short-lived. Heresies always draw their strength from part of the truth, at times even from the very "center of the Christian message." 2

(2) Since the church is composed of sinful men, 1ts treasures of truth have "always co-existed with some errors." Unknown truths and errors, unfulfilled tasks and sin on the part of the church have often been "the decisive reason for heresy, the point at which it mounted its attack." 3 Many Christian apologists, remarks Küng, took over Hellenistic concepts. This, which can be considered "quite simply an inevitable process," meant in the long

I Ibid., p. 317 .

2"Selectivity, which is the essential feature of heres;, does not only lead to error; it can very often lead to an impressive degree of concentration, in which a single trait, perhaps a vital trait, and even, as in the case of Marcion, the real centre of the Christian message, can be brought out in a new way that is all too often neglected by the Church" (Ibid., Pp. 318-19; emphasis in the original).

${ }^{3}$ Ibid., p. 319. 
run that essential aspects of the orfiginal Christian message, and in particular of the preaching of Paul and John were overshadowed. 1

Thus, "In all ages the Church has been partly responsible for the rise of great heresies." From this perspective, heresy may be regarded as fulfilling the function of "warning and admonishing the Church," holds Küng. 2

(3) Over against the opinion of early opponents of heresy such as Justin, Ignatius, and Irenaeus, Küng holds that the reason why people become heretics cannot be attributed simply to "the work of Satan, who brings about apostasy from orthodox doctrine." Had the voices of these heretics been preserved, we would find that they "wanted the best for the Church, that they acted in good faith," affirms kung. This conclusion can be drawn from their total commitment to their ideas. "In this sense the great heretics were like the great saints." They rarely took an easy road, but sacrificed everything to their faith. ${ }^{3}$

In addition to these three points regarding the nature of heresy underlined by kung, other aspects mentioned by him in this context deser:s to be stressed as well.

Notice first the church-heresy antithesis: Kung holds that "heresy" is in opposition to "the ecclesia" since it questions the

Infalse accents were placed and false developments took place, especially in a religion which was increasingly governed by laws. Marcion was able to put his finger on these weaknesses of the Church of his time, and this is why his heresy, with all its errors, had such a success" (Ibid., p. 320).

${ }^{2}$ Ibid.

${ }^{3}$ IbId., pp. $321-22$. 
whole basic faith of the latter. ${ }^{1}$ Even though heresies fulfill the useful function of "preventing the Church from becoming rigid and paralyzed In its 1 ife and Its teaching, " 2 they cannot be justifled. Since they represent "an unorthodox conception of the Gospel," they must be "rejected and overcome." 3

Next, in the NT, heresy is condemned "not, as in philosophy, by reference to a supposedly correct (óptós) system, but by reference to the true message of salvation." 4 Küng states time and again a concept obviously important to him, that discrepancies must be measured "not against one's own theology, but against the orlginal message of the Gospel." 5 When he recommends that the church should Iisten to the concerns and demands of heretics and act accordingly, he observes that the church should measure these concerns and plan its actions "in the light of the Gospel of Jesus Christ. 6

Finally, the explanation which "several modern scholars" have found for the origin of heresy, namely, that "heresy arises from the struggle betwesn majorities and minorities in the Church,

1Ibld., P. 315.

2 Ibid., p. 331.

3 Ibid.

"Ibid.; cf. "New Consensus," p. 14 (principle No. 7).

5 Ib1d. , p. 330 .

6 Ibid. 
in which victorious majorities classify defeated minorities as heretics," is deemed by küng as an "extreme simplification." I

In this context, "What is the proper way for the Church to confront heresy?"2 Küng's answer is as striking as it is simple.

First, love must be the rule even in matters of falth. Here the gospel of Jesus Christ again teaches us that God's love "excludes no one, not even one's enemles." 3 Even though there may be ocrastons when the life and order of the community is seriously threatened by false teachings, In which cases the church, "exercising the spiricuai authority of her Lord, can saver comunion ylth a heretic or hereties in order to protect and presarv: the community,"4 it always must act in consunance with its having been called "to be the body of Christ in love."S "The very idea of destroying heretics, whether physically or 'merely' spiritually, must be totally alien" to the church. 6

Next to love, the basic attitude necessary for debates in matters of faith is understanding. "Finding the punctum veritatis in their viewpoints" instead of quoting out of context some

IIbid., p. 321. In Kung's opinion, "The disputes in the history of the Church are surely not decided so fortultously; the question of who bases his view on the original Christian message is surely not irrelevant in the forming of a majority and the outcome of any struggles" (tbid.).

\footnotetext{
Ibid., p. 327 .

${ }^{3}$ Ibid., p. 328 .

${ }^{4}$ Ibid., p. 322 .

${ }^{5}$ Ibid., p. 329 .

${ }^{6}$ Ibid.
} 
statements of heretics and "constructing and condeming a caricature" of them ${ }^{1}$ is not merely a manifestation of the love of the church toward heretics. The church must make a real effort to understand their valid concerns and demands in order to "weigh up these concerns carefully, and be prepared to take action on them to the extent that they are justified in the light of the Gospel of Jesus Chrise." 2

Finally, and to no one's surprise, heresy should be seen as a challenge to the church, inviting it to discover a deeper and more complete unity. 3 That "it is not easy to distinguish absolutely between truth and error" 4 means that there is always an element of truth in heresy as well as some errors in the church.5 Every heresy, then, makes it possible for the church, if it understands the valid concerns of heretics, to discover "something better" 6 than the orlginal position of both the heretic and the orthodox. 7

I Ibid., Pp. $329-30$.

2 Ibld. , p. 330.

${ }^{3}$ Ibid., pp. $331-33$.

${ }^{4}$ Ibid., p. 332.

${ }^{5}$ Ibid., pp. 317-21.

${ }^{6}$ Ibid., p. 333.

${ }^{7}$ Kung qualifies in this way his original assertion that "the unity of the body of Christ is always endangered.. . by heresy" (ibid., p. 313) by affirming that "Heresy should be seen, not as primarily a challenge to the unity of Church fellowship, but rather as a challenge to the Church to discover a new and a deeper and a purer unity" (fbid., p. 333). 
To sum up, three salient features of our theologian's view on heresy are the following. In the first place, for kung the essential feature of heresy is its one-sided and selective approach to the totality of revelation. In his eyes heresy is not to be understood merely as error but also, and mainly, as selectivity and concentration in particular aspects of Christian doctrine. 1 Further, heresy is not only a selection from the totality of revelation and from the NT Canon. It is selectivity regarding tradition as well, as for example in the case of that selective understanding of the councils of the church which absolutizes the position of the first Vatican Council over against the teaching of the Council of Constance as far as papal primacy is concerned. ${ }^{2}$

In the second place, Küng holds that truth and error are not categories which can be distinguished in a clear-cut way. They often co-exist, both in the church and in the views advocated by heretics. ${ }^{3}$ Since truth and error abide in the positions of both the orthodox and the heretic, what essentially distinguishes one from the other? It is by no means any arcunt of truth or of error, holds Küng, but an overall attitude toward the church. Prodded by his conscience, the heretic rebels and feels he must stick to his convictions. He "does not submit to the authority of the Church."4

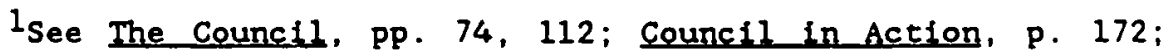
Structures, pp. 167, 313; the Church, pp. 40,316,318-19; Theologie Im Aufbruch, 98, 102-08.

2 structures, pp. $312-13$.

${ }^{3}$ The Church, p. 332 ; Menschwerdung, p.

${ }^{4}$ The Church, p. 323. 
This is what distingulshes the heretic from the saint, holds Küng. The latter may often be in conflict with the authority of the Church but will finally accept it patiently and humbly.

Finally, it must be noticed that kung holds a view of the church's untty which differs from the historical position of the Roman Catholic Church on this matter. For the latter, the church must be united around "true and pure doctine," which is defined, explained, and preserved by the church's Magisterium. I Those who reject the teachings of the church are considered its enemies, guilty of the sin of heresy and thus excluded from the community of the saints. For küng, true unity is achieved when the church is able to understand the view of the heretics, modify its life and teaching according to their valid concerns and in harmony with the teachings of the original gospel. This is how the unity of the body of Christ is authentically preserved, while at the same time lts understanding of Christian truth improves. Such a view has, of

Isince the church's teaching authority is believed to be protected by God's grace from error in proclaiming binding dogmas, Roman Catholics affirm that this infailible teaching authority is exercised (1) by the universal episcopate when, under 1 ts head the pope, it teaches with moral unanimity whatever doctrine God has revealed to the church (the magisterium ordinarium), (2) by an ecumenical council under the leadership of the pope, and (3) by the pope alone, when as supreme teacher of the church (ex cathedra) and invoking the plenitude of his teaching authority he pronounces a doctrinal definition as binding on the whole church. The second and third authorities are called the magistertum extraordinarfum. Since the church's authentic magisterium is infallible, "all are. . bound to shun any contrary doctrines" (CCL 1983, can. 750 . Cf. ibli., can. 752, 753, 754), otherwise they must be considered heretics (CCL 1983, can. 751). 
course, major impiications for Küng's concern for che reunion of aiI Christian churches--the unity of the "Ecclesta Catholica." 1

\section{Summary and conclusion}

The purpose of this chapter was to briefly set forth Küng's attitude toward the principles of authority and succession-tradition undergirding the "revelational" and "ecclesiastical"2 criteria of orthodoxy. My intention was also to examine Küng's understanding of the norms of classical orthodoxy, namely, the teachings of the apostles, the NT Canon, the oral traditions of the church, and the pronouncements of the eplscopal Magisterfum. Finally. I planned to consider the Swiss theologian's position on the issue of the unfty of the Catholic doctrine, which bears upon his concept of heresy.

As for the principle of religious authortty, this chapter makes it plain that Küng's leading pastoral concerns (i.e., the

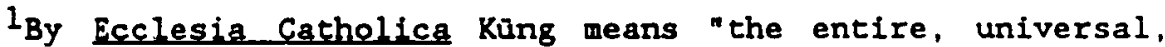
all-encompassing and whole Church." There is, in his eyes, a "Catholicity in time," namely, "the continuity of faith and of the faith-community, a continuity which endures in spite of all breaches." There is also a "Catholicity in space," namely, "the universality of the falth and of the falth-communtty, which encompasses all groups" ("Statement of Professcr Küng, December 20 , 1979," in Küng Dialorue, p. 169).

${ }^{2}$ As pointed out in the first chapter, by "ecclesiastical criterion" we mean the notion that authentic Christian doctine is preserved only within the church. From a historical perspective, the emergence of the ecclesiastical criterion of orthodoxy was the result of the mainstream church's attempt to counteract the position of the "heretics" who clatmed to possess a secret oral tradition. The increasing importance attributed to the ecclesiastical criterion meant that eventually the principle of authority, first expressed in the "revelational" criterion of orthodoxy, was applied preeminently to the two ecclesiastical norms of the oral tradition and the magistertal pronouncements. In this way, in the Middle Ages, the notlons of "truth" and "church" became almost synonymous. 
reunion of Christianity and the credible presentation of the gospel to modern-minded humanity) compelled him to confront the Roman Catholic model of authority advocating a renewed authority, 1.e.. one aware of both what is Involved in the original Christian message and required at the present time. Though he explicitly stated that he was not speaking against authorlty in the Church, but for it, Küng was also careful to point out that the Roman Catholic way of exercising religious authority constituted the number one stumbling block to Christian unity. He thus proposed an attitude of the church's Magisterium which would reveal its evangelical and servant nature rather than an authoritarian one. He also advocated the duty of theologians to assist the Magisterium in its teaching activity through the discermment, by scholarly means of modern research, of whether the church speaks correctly of God.

Always within the context of the principle of authority and wthin the bounds of his intra-Catholic discussion, Küng stressed the norms related to the revelational criterion of Christian truth over against those belonging to the category of the ecclesiastical criterion. Even though he may not have dealt at length with the doctrine of revelation nor with the relationship existing between his own view of zevelation and the traditional revelational criterion of orthodoxy, his confessed ultimate norm of Christian truth falls within the realm of the latter criterion: it is the gospel of Jesus Christ as orlginally proclaimed by the apostles and recorded in the NT Canon. In Küng's eyes the proclamation of the 
apostles is the fundamental and, for all time, standard-setting testimony of Jesus Christ.

As a corollary, Kūng regarded the norms of orthodoxy which fall within the scope of the ecclesiastical criterion of orthodoxy (namely, the post-biblical oral traditions and the pronouncements of: the Magisterium) as the norme nermata of Cinristian truth, 1.e., ij secondary to the normativity of the original sources of the Christian faith. True, both the original apostolic teaching and the Canon of the New Testament belong to the tradition of the church and came into existence within the Christian community. Yet, he stresses the fact that the post-apostolical or extra-biblical traditions derive their normative value from the normativity of the original sources. The Swiss theologian insisted that "Sacred Scripture is thus the norma nommans of the Church's tradition, and tradition must be seen as the norma normata."

It must be noticed that Küng's stress on the normativity of the Scriptures over against the traditions of the church took place during the first stage of his theological development (in the $\left.1960^{\circ} \mathrm{s}\right)$, In the context of the intra-Catholic discussions related to the ecumentcal awakening of the Roman Catholic Churcin. Küng's subordinating tradition to the sassetivity of the Scriptures provided him with the necessary ground for an ecumenical approach to the issue of authentic Christian belief and teaching (orthodoxy). On the other hand, it gave him a theoretical support for his call to revise the doctrinal mistakes of the Roman Catholic Church in order to proclaim the gospel to the modern world in a more credible 
manner. In his dlalogue with Protestants, however, Küng underlined the "catholicity" of the NT and questioned the selectivity and onesidedness which, in his view, is characteristic of Protestantism. The latter's unilateral approach to the Canon, he noted, is of the essence of "heresy."

Within the context of the issue of the unity of the church's doctrine, and in what touches upon the antithesis of the church and the heretics, Kung questioned the official teaching of Roman Catholicism. True unity of the body of Christ is not achieved by merely denouncing a dissenter's position and, after qualifying it as heresy, by proceeding to sflence or destroy him. The church should rather pay attention to the concerns of heretics and be prepared to correct whatever is necessary in the light of the gospel of Jesus Christ. In this way, the church would grow in its apprehension of truth and should be able to prevent unnecessary tresks in the body of Christ.

Of particular significance is the fact that, in Küng's view, the antithesis church-heretics cannot be simply equated with the truth-error antithesis. There is truth and error in both positions whether of traditional "orthodoxy" or of varlous dissenters. In Küng' 3 view, "heresy" is not to be understood merely as error but also and mainly as selectivity and concentration in particular aspects of Christian doctrine.

What comes out as an important conclusion at the end of the analysis of Kung's views thus far is that his confessed final criterion of Christian truth (orthodoxy) is the gospel of Jesus 
Christ as originally proclaimed by the apostles and recorded in the NT Canon. Since "the writing of the New Testament is a manifestation of the living apostolic proclamation, "1 we may reduce, for the sake of simplification, the two original norms of orthodoxy--1.e., the teachings of the apostles and the NT Canon--to one, namely, the New Testament. Yet, a problem remains concerning küng's ultimate norm of Christian truth. Since he distinguishes between the Scriptures and the gospel. 2 the question arises as to which one is indeed his ultimate norm.

An answer to the preceding question might be found in affirming that the NT Canon is, methodologically speaking, hung's norma normans for Christian doctrine. In other words, the Scripture constitutes for kung "the locus" or primordial source of doctrine. This seems to be particularly true when he addresses intra-Catholic problems such as the Magisterium's claim of infallibility. ${ }^{3}$ on the other hand, the gospel is the basic Chrlstian message of God's grace which sustains the theologian's personal faith. As such, the gospel would not function as a norm of orthodoxy but as the existential source of Chrlstian power.

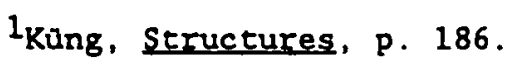

2 See, for Iistance, Infallible?, pp. 217-18; Christian, p. 501; and Küng, "Theologie auf dem Weg zu einem neuen Paradigma," in Johannes B. Bauer, ed. Entwirfe der Theologie (Graz, Vienna, and Cologne: Styrla Verlag, 1985), p. 192.

${ }^{3}$ In other contexts, however, Küng defends the Catholic approach to tradition (which he labels "catholicity in time") against what he regards as the discontinuity of Protestantism. 
Apart from this, when addressing the necessities of modernminded men and women, Küng affirms that the Scriptures, in particular those of the NT, must be understood from a historicalcritical perspective if one wants to know the message of the real. historfcal Jesus. Though Küng methodologically regards them as the norma normans non normata, ${ }^{1}$ the canonical Scriptures have normative value for faith only when used as a means of gaining access to the essence or substance of the Christian faith, namely, the actual Jesus of history and his original message. ${ }^{2}$ In the biblical writings, holds Küng, we find the essence of God's message clothed in cultural and time-conditioned forms. ${ }^{3}$ This makes it difficult to distinguish, throughout the history of the church and theology, heresy from orthodoxy in a clear-cut manner.

The modern scientific-historiclst hermeneutical criterion will make every effort to maintain unmodified the essential truth of the gospel. The question as to what extent is that possible involves a decision concerning what is "essential" and what pertains to the shifting "forms" of expression of Christian truth. It entails as well, it seems, a decision regarding what the ultimate norm will be, whether the NT Canon Itself or the current world-view and horfzon of understanding.

$1_{\text {See, for instance, The Church, p. 36; Theologie im }}$ Aufbruch, P. 87 .

2 See Küng, "New Consensus," pp. 6-8; cf. Dulles, Models of Revelation, p. 196.

\footnotetext{
3 "New Consensus, " p. 6.
} 
This problem was brought concretely into the foreground by the suggestion of the Conference of German Bishops which, reacting to Küng's theology in its Declaration of February 17, 1975, 1 pointed out that historical-crittcal exegesis, though indispensable as a help, involves the potential danger of being selective in the use of the biblical data. Catholic faith, recalls the Conference, lives out of "the whole of Scripture." In what strikes one as a statement drawn from one of Küng's own volumes, the bishops remind our theologian that a truly Catholic approach does not permit a "onesided or even an exclusive preference for some, most 'earlier' layers, nor does it permit discrimination against later stages of development" within the New Testament Canon. 2

Catherine LaCugna, for her part, suggests that in his use of the historical-critical exegesis kung makes this method to replace Tradition as the authoritative interpreter of the scriptures. ${ }^{3}$ Moreover, in LaCugna's view, the Swiss theologian seems to put historical criticism above the scriptures as well, despite his alleged intention not do so. 4

The model of orthodoxy-heresy advorated by kung thus seems to present a difficulty which can be expressed in the following

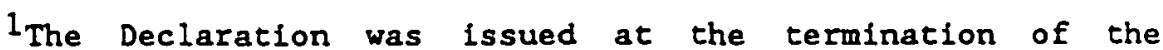
doctrinal proceedings of the CDF relative to Küng's volumes The Church and Infallible? (For the complete text of this Declaration, see küng Dialogue, Pp. 94-98).

2 Ibid., p. 95.

${ }^{3}$ LaCugna, Methodology of Küng, pp. 173, 177-79, 203-04.

${ }^{4}$ Ibid., pp. 173, 174-77, 182-95. 
terms: Heresy, which according to him can be basically defined as a selective approach to the Christian message, is to be measured against the gospel of Jesus Christ as originally witnessed in the New Testament writings. However, kung clings to the view that these writings share in the "time- and culture-bound images, concepts and Erames of referencen ${ }^{I}$ characteristic of their time. To bridge the gap between the conceptual frame of the biblical times and our own, and to recover "the original outlines of the message of Jesus," 2 Küng has confidence in the suitability of the historical-critical approach to the biblical text. Since, in a sense, historical criticism works with the central assumption that the accounts of the Scriptures do not necessarily describe things as they actually happened, ${ }^{3}$ it is necessary for the exegete who relies in these wethods to constantiy discrimingte between texts in the Bible. This discernment implies a "selection" within the Canon of Scriptures which, in principle, though in a different sense, Küng regards as heretical and thus condemnable. This, of course, would mean a crucial inconsistency in Kung's theology.

Thus, the speciflc question that we need to address now is whether Küng's concept of heresy is consistent with his own interpretation of the Canon, which he methodologically regards as the norma normans of Christian belief and teaching. To what extent

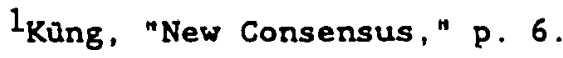

2 Ibid., p. 7 .

${ }^{3} \mathrm{Cf}$. Raymond E. Brown, Biblical Exegesis and Church Doctrine (New York/Mahwah: Paulist Press, 1985), p. 11. 
does Küng's scientiflc theology play a decisive role in his way of deterwining what is correct and genuine Christian teaching? We need indeed to examine the question as to which is really Küng's ultimate norm, the NT Canon or the conclusions reached by means of the modern historical and sclentific ways of thinking. 
CHAPTER IV

MODERN CRITERIA AND NORMS OF ORTHODOXY

The discussion in chapter 3 showed that in his confrontation with the traditional Roman Catholic position, Hans Küng asserted that the ultimate criterion of orthodoxy ${ }^{1}$ is the gospel of Jesus Christ, which is to be read in the New Testament using historicalcritical principles of exegesis. The question raised, however, was whether Küng's scientifichistoricist criterion should not be regarded as having a determinant role in his way of distinguishing what he considers to be the true Christian message. Moreover, the critical question was posed wiether these two criteria--namely, the gospel as witnessed in the NT Canon and the modern historicalscientific approach to the canonical writings--are indeed compatible in Küng's model of orthodoxy-heresy, particularly with his concept of heresy as selection from the totality of revelation.

In chapter 3 I addressed Küng's position regarding the principles of authority and tradition, as well as his understanding of the revelational and the ecclesiastical criteria of classical orthodoxy with their related norms. It was shown that he clings to

$1_{\text {We must recall at this point that I am using the terms }}$
"orthodoxy," "correct belief and teaching," "true Christian
doctrine," and "Christian truth" as synonyms.


the original norms ${ }^{1}$ of Christian doctrine for his definition of Christian truth. The task of the present chapter is to analyze the manner in which Küng deals with the main theological issues raised Erom the time of the protestant Reformation concerning the orthodoxy-heresy antithesis, as well as with the hermeneutical criterion of truth undergirding his scientific-historicist approach to theology.

In analyzing Küng's understanding of the modern issues and criterla related to orthodoxy-heresy, attention is given to his concept of truth as such. This should hopefully clarffy and explain how, in his view, Christian truth is expressed in the Scriptures and in the pronouncements of the Magisterium. We should also be able to appreciate the justification for his use of the historical-critical methods of biblical exegesis.

The first half of this chapter, therefore, is devoted to Kung's notion of truth and the related issue of doctrinal infall1billty (the infallibility of human propositions as such, and the infallibility of both the Magisterium and the Scifptures).

The second half teals with another relevant issue belonging to Kung's model of orthodoxy-heresy. The fact that, according to him, the "old gospel" needs to be proclaimed to the contempurary world in a manner relevant to the "modern horizon" of understanding. means, among other things, that in the church's proclamation there is something which changes (the "hortzon of understanding") and

$1_{\text {Namely, the teaching of the apostles and the canonical }}$ Scriptures, especially those of the NT. 
something which must persist through all changes (the gospel). Küng's theory of "paradigm-change," which explains how we make progress in theology and how, at times, today's heresy may become tomorrow's orthodoxy, shall occupy our attention in the second part of this chapter. This will then provide us with all the essential elemer.ts of Küng's concept of orthodoxy-heresy needed to address critically his views on this question.

\section{Part One: On the Issues of Truth and Infallibility}

The issues of truth and Infallibility are here addressed together for two main reasons. First, the theological meaning of infallibility is, basically, the alleged condition of the church which is divinely assisted for preserving the truths of revelation. 1 Second, both questions of truth and infallibility are at the very center of the problem of this dissertation. On the one hand, the issue of Infallibility is at the core of Kung's controversy with the Vatican. 2 on the other, the problematic of orthodoxy-and-heresy has to do in essence with the definition of religious trutit and error. ${ }^{3}$

\footnotetext{
I"The positive content of the term Infallibility is simply 'truth' or 'truthfulness'," note H. Fries and J. Finscerhölzl ("Infallibility," SM [1969], 3:132).

${ }^{2}$ The Vatican Declaration which announced the dismissal of Kung from his position as Catholic professor of theology (see above, p. 9, n. 4) concentrated on "the infallibility question," thus making of this the central issue of a controversy that had lasted already for more than twenty years (see CDF, "Declaration," in Küng in Conflict, pp. 386-87; cf. "Letter of Cardinal Seper to Hans Küng. December 15, 1979," in ibid., p. 389).

${ }^{3}$ See above, "Introduction," pp. 2, 10, 11.
} 
The search for truth. 1 which is the endeavor of natural scientists and historians ${ }^{2}$ as well as of philosophers and other scholars, is of interest to theologians, $t 00,{ }^{3}$ and occupies a central place in the Christian religion. Though no one today would seriously assert that truth in science and the humanities and truth in religion are verified in the same way, ${ }^{4}$ the fact is that theology as well as the other disclplines of knowledge share an interest in truth which constitutes an essential characteristic of human beings

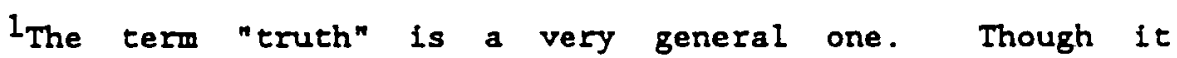
frequently requires qualification--we can speak of scientiflc truth, historical truth, factual truth, mathematical truth, juridical truth, moral truth, personal truth, and so on--it is generally recognized that the common meaning of the term is "conformity with fact" or "agreement with reality"; in general, "correctness" and "verity" of statement or thought as opposed to their "wrongness" and "Ealsity" (See "Truth," The Oxford English Dictionary [1933], 11:435). Thus, in common usage "truth" is taken to involve an agreement or correspondence between what is said or just thought and what is so. It is in this sense that I am using the term here ( $C f$. Robert P. Scharlemann. The Beine of God: Theology and the Experience of Truth (New York: Seabury Press, 1981], p. 11).

2 When a scientific description or a historical statement is said to be "true," what is usually meant is that it corresponds to the facts, which, in the first case, may be verified by scientific tests, and in the second, elther by living witnesses or by documents. Regarding the notion of truth as correspondence with facts, see the discussion below, on PP. 262-67.

${ }^{3}$ Küng points out correctly that even though theology must aspire to clarity, "it cannot expect to find the kind of clarity offered by mathematics and the cognate sciences, as long as the latter simply claim to depict the object and the objective sphere without asking what lies behind them" (Infallible?, p. 168).

${ }^{4}$ Some even think of theology as a matter of confession but not of verification. Hilary Putnam observes that with the increase in admiration for the exact sciences which is a characteristic of the "cultural tide" of our time, some have argued that there is no knowledge to be found in other disciplines or sciences (Putnam, Reason. Truth and History (Cambridge: Cambridge University Press, 1981], P. 150). 
as such. ${ }^{1}$ Moreover, as it was mentioned in the first chapter, the categories of orthodoxy and heresy appeared in the history of the Christian church due precisely to the Christians' concern for truth and the preservation of the authentic Christian teaching. ${ }^{2}$

The urgent question at this point is, specifically, what is "truth"? In other words, what do we mean when we say that what is expressed in a given proposition is true? This is a problem of philosophical nature. Though a lengthy and technically detalled study of the philosophical understanding of the nature of truth is beyond the scope of this dissertation, some attention should be paid to the matter at the outset of this discussion. A brief review of the main philosophical theories of truth seems indispensable for a better understanding of our analysis of kung's concept of truth.

\section{Main Philosophical Theories of Truth}

Discussions about truth in modern philosophy are "extremely complex. ${ }^{3}$ It may be affirmed, however, from a historical perspective, that the main theories of truth can be reduced to the following four: correspondence, coherence, pragmatic, and performative. ${ }^{4}$ of these, the most common in the history of philosophy is

$1_{C f}$. Scharlemann. The Being of God, p. vii.

2 See above, pp. 23-25.

${ }^{3}$ See Anthony C. Thiselton, "Truth, N NIDNTI (1986), 3:894.

${ }^{4}$ Vincent Brummer asserts that these four theories of truth are the basic ones, of which all other theories are variations. He presents a brief description of them in his volume Theo.ogy and Philosophical Inquity: An Introduction (Philadelphia: Westminster Press, 1982), Pp. 169-181. See also A. C. Ewing's survey of the 
the so-called "correspondence theory," followed in importance and influence by the "coherence theory." I It is suffictent for my purposes to briefly consider the main characteristics of these two views as stated by both their chief proponents and critics.

The correspondence theory

The basic tenet of the correspondence theory is that beliefs or statements are true to the extent that they represent accurately the things in themselves of which they are mental images.

Plato already in his Sephist attempted to demonstrate that "opinion"-i.e., the affirmation or denial which takes place in silence and in the mind only ${ }^{2}$-.exists in our minds either as true or

correspondence, coherence, and pragmatist theories in his The Fundamental Questions of Phllosophy (London: Routledge \& Kegan Paul, 1951), chap. 3. Alan R. White discusses the same "three traditional theorles" in his book Truth, Problems in Philosophy series (Garden Clty, New York: Anchor Books, Doubleday \& Co., 1970), Pp. 102-27. Other theories are also discussed in this volume.

${ }^{1}$ CE. Thiselton, "Truth," pp. 894-896. For a short account of the development of the correspondence theory, see A. N. Prior, "Correspondence Theory of Truth," The Encyclopedia of Philosophy (1967), 2:223-232. See also Daniel J. O'Connor. The Correspondence Theory of Truth (London: Hutchinson \& Co.. Publishers, 1975); and Christopher J. F. Williams, What Is Truth? (Cambridge: Cambridge University Press, 1976), pp. 74-96. For a basic bibliography and a thorough discussion on the coherence theory, see Nicholas Rescher, The coherence Theory of Truth (Oxford: At The Clarendon Press, 1973). An exposition of the pragmatic theory is found in William James' The Meaning of Truth: A Sequel to "Pragmatism" (New York: Longmans, Green, and Co, 1909).

2Plato Sophist 264. The English translation of Plato's work used here is Benjamin Jowett's, in The Dialogues of Plato, Great Books of the Western World, vol. 7, Plate, ed. Robert Maynard Hutchins (Chicago, London, and Toronto: Encyclopaedia Britannica, 1952), pp. 551-79. 
false. 1 Equating thought and speech, ${ }^{2}$ he affirmed that "every sentence must necessarily have a certain quality, " namely, it must be either true or false. "The true says what is true" about something or somebody, "and the false says what is other than true." 3 To use his own example, it is false that Theaetetus is flying if he is not flying, and it is true that he sits if he sits. This can be regarded as the earliest known exposition of the correspondence theory.

Though Aristotle took the correspondence theory over from Plato, his famous dictum has been regarded by some as the first statement of that theory. ${ }^{4}$ It goes as follows: "To say of what is that it is not, or of what is not that it is, is false, while to say of what is that it is, and of what is not that it is not, is true." 5 Among Christian philosophers, Augustine held the correspondence theory when he affirmed that "the true is that which is." 6

1 plato Sophist 263 (The Dialorues of Plato, p. 577).

2 "That what is called thought is the unuttered conversation of the soul with herself" (ibid.).

3 plato Sophlst 263 (The pialorues of Plato, P. 576).

${ }^{4}$ See Stephan Korner, What Is Phflosophy? (London: Penguin Press, 1969), p. 101. CE. Williams, What is Truth?, p. 74.

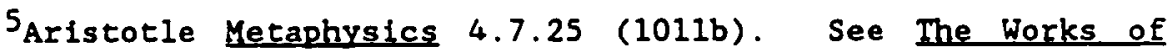
Aristorle, Volume I, Great Books of the Western World, vol. 8, Aristotle: I, trans. W. D. Ross, ed. Robert Maynard Hutchins (Chicago, London, and Toronto: Encyclopaedia Britannica, 1952), p. 531 .

${ }^{6}$ Augustine Sol1logulorum 2.5 (PL, 32:888). Or, "truth is that which shows forth what is" (Augustine De vera religione 36.66 [PL, 34:151]). Cf. Aquinas Summa Theologica 1, Q.16, 1 (see St. Thomas Aquinas, Summa Theolortae: Latin Text and English Iranslation. Intro-duction. Notes. Appendices and Glossaries, 60 vols. [New 


\begin{abstract}
Thomas Aquinas observed that according to Augustine's definition, It would seem that truth does not reside in the intellect but in things. I since Aquinas believes that "truth is primarily in the intellect and secondarily in things," he prefers the definition, which has tecome a classic statement of the correspondence theory, "Truth is the equalizing of the thing and the mind. 2
\end{abstract}

We may conclude that undergirding the ancient and medieval concepts of truth--which can be conceived as early versions of the "correspondence theory".-Is the notion that truth is objective and may be known objectively. 3

The correspondence theory is by no means restricted to the anclent and medieval perlods. In the twentieth century it is not without renowned exponents. Bertrand Russell, for instance, finding the coherence theory of truth questionable, advocates the correspondence theory--which he describes as "the commonest among

York: McGraw-H11I Book Company; London: Eyre \& Spottiswoode, 1964]. $4: 75,77)$.

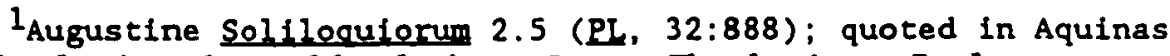
Summa Theolegica $1, Q .16,1$ (see summe Theologiae, Engl. trans., 4:75).

2 "Veritas est adaequatio rei et intellectus" (Thomas Aquinas Summa Theologlca I, Q.16, I (see Aquinas, Summa Theologiae: Latin Text and English Translation, 4:78, 79). It is probably due to Aquinas' formulation of this theory that Edward $M$. Mackinnon qualifies the notion of "truth as correspondence" as "scholastic" par excelience (Mackinnon. Iruth and Expression: The 1968 Hecker Lectures [New York, Paramus, and Toronto: Newman Press, 1971], pp. 141-42).

${ }^{3}$ I must observe at this point that it is possible to doubt the total adequacy of human comprehension of truth while affirming the correspondence theory. 
philosophers"-to explain the nature of truth: "Truth consists in some form of correspondence between belfef and fact." 1 Another contemporay exponent of the correspondence theory is Alan White, who observes that "the Correspondence Theory of truth is correct in Its claim that what is said is true if and only if there is a correspionding fact. ${ }^{2}$

This notion which in some sense holds a factual, objective view of truth is questioned by the "coherence" and other theories. Let us now address briefly the main features of the theory which is second in importance and influence only to the correspondence theory, namely, coherence.

The coherence theory

The coherence theory explains truth as a relation of judgments or statements to other judgments or statements, not =o reality. According to this theory, an opinion should be accepted as true only if it is coherent with other opinions already accepted as true.

Among the defenders of the coherence theory, Nicholas Rescher declares that his book on this particular topic seeks to transform "a defunct and discredited philosophical theory into a significant instrument of epistemology."3 Hilary Putnam, for his

l Bertrand Russe11, The Problems of Philosophy, Home University Llbrary of Modern Knowledge serles, 35 (New York: Henry Holt and Company; and London: Thornton Butterworth, n/d), p. 190.

${ }^{2}$ Alan White, Truth, p. 129.

${ }^{3}$ kescher, The Coherence Theory, p. vil. 
part. defends a philosophical point of view which he labels "the internalist perspective."I Truth, in an internalist view, holds he, is some sort of ideal coherence of our beliefs with each other and with our experiences "as those experiences are themselves represented in our bellef system--and not correspondence with mindindependent or discourse-independent 'states of affairs'." 2 In his opinion, "Coherence" as well as "Pluralism" and "Pragmarlsm," among others, are all terms that have been applied to what he calls the internalist perspective. ${ }^{3}$ He also holds, correctly, in my view, that the "Internalist" (1.e., coherence and pragmatist theories) and the "externalist" (or correspondence theory) are the two basic philosophical perspectives which deal with the issue of truth. ${ }^{4}$ Among the contemporary critics of the coherence theory, Mackinnon pertinent?y observes that even though valuable in some sense, it does not represent an insight lnto the meaning of what is "true. $n$

I an of the opinton that the correspondence theory is contested from the perspective that things in themselves are in

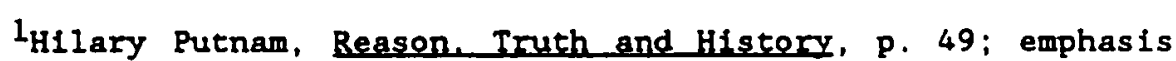
in the original. This author distingulshes between two philosophical perspectives, the "externalist" and the "internalist," which, in his view, affect "about every issue in philosophy." As for the externalist point of view, it is identified with the correspondence theory of truth (ibid.).

2Ibid., pp. 49-50; emphasis in the original.

${ }^{3}$ Ibid., p. 50 .

4see chapter 3, "Two PhIlosophlcal Perspectives," In Ibid., pp. 49-74.

5Mackinnon, Iruth and Expresston, p. 24. 
principle inaccessible to the knowing subject, that it is simply impossible to discover whether one's beliefs are true. ${ }^{1}$ Thus, the coherence and all other theories give, in general, a more relativistic solution to the problem of truth. In this connection. Anthony Thiselton holds that there is in our days a certain "measure of scepticism about truth," and for that reason "our own age often feels obliged to rest content with a kind of relativism which reveals extreme pessimism about questions of truth." 2 It might be affirmed, therefore, that what is at issue in the position of the two main theories reviewed is a confrontation between a subjective, more relativistic, and an objective conception of truth.

Two Dimensions of Truth

Apart from the two basic approaches to the nature of truth represented by the philosophical theorles fust reviewed, two other dimensions of truth deserve to be mentioned since they also bear upon kung's view. They are the "cognitive" or intellectual and the "personal" or existential aspects.

On the one hand, it is affirmed that only bellefs and statements can be said to be true or false in a philosophical sense. ${ }^{3}$ Rescher explains: "Phflosophical theorfes of truth in general deal exclusively with the truth of statements or propositions." 4

${ }^{1}$ Cf. B. Russel1, Problems of Phtlosophy, p. 190.

${ }^{2}$ Thiselton, "Truth," NIDNTT (1986), 3:899.

${ }^{3}$ See B. Russel1, p. 189; Rescher, p 1; Brümmer, p. 169.

"Rescher further explains: "Other uses of 'true' in ordinary language (such as its adjectival use in contexts like 'a true 
Similarly, Brimmer remarks that "In epistemology we are primarily concerned with proposftional truth, that is, the truth of constative beliefs or constative assertions." 1 We refer to this approach in the remaining part of this dissertation as the "cognitive" dimension of truth.

On the other hand, writers such as Ellot Deutsch note that there is a second dimension to "truth"--reflected in the Latin, Sanskrit, Arabic, and Hebrew terms--which defines it not just as a property of statements, proposftions, or bellefs; "it is a quality of being, of human beings and human activities."2 In Deutsch's view, the restriction of "truth" to propositions--which he regards as the result of "the impact of positfrism"-. is wrong and unfortunate "for it robs the concept of some of its richest possible meaning." 3 This dimension (which we label hereafter the "personal" dimension of truth) is discussed in the following section dealing with the notion of truth in the Bible, where truth is referred to as having both a personal and an cognitive dimension.

friend' or 'a true IIne' or 'a true artist') are beside the point of concern" (RescheI, The Coherence Theory, p.1).

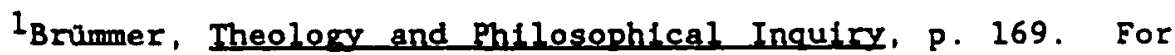
his explanation of "constative assertions," see lbid., pp. $17 \mathrm{ff}$.: "We perform a constative in a speech act when we assert in it that a certain state of affairs exists in reality. It is therefore characteristic of all descriptive statements that they have a constative function. . . Constatives differ from all other illocutions in that they may be judged to be Exue or false."

2E1lot Deutsch, On Truth: An Ontologteal Theory (Honolulu: The University Press of Hawali, 1979), p. 1.

3 Ibid. 
Truth in the Scriptures

According to the Gospel of John, Jesus spoke of the great controversy between God and the devil--a motif that may be considered central throughout the Scriptures--as a conflict between "the truth" and "a liar" (John 8:40-46). Jesis stated that the reason of his coming into the world tys "to testify to the truth" (John 18:37). Moreover, He affirmed to be himself "the way, the Eruth, and the life" (John 14:6).1

For the Christian belfever, then, the truth is first and foremost Jesus Christ himself. Truth has for him or her essentally a personal or existential dimension. 2 This means that the believers

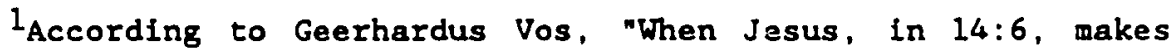
the triple identification between the 'way,' the 'truth,' and the 'Iife,' and Himself,. . . the context shows that what was in question was the 'way' to the place whlther Jesus was going. . . He is the way to this because He Himself is bound for this. The identification with Him furnishes absolute certainty to the disciples' arriving there. This is further made clear by the two following explicative concepts: He is specifically the truth, the veritable essence of that region to which He is going; and within that essence again He is the life characteristically belonging to it" (G. Vos, "True' and 'Truth' In the Johannine Writings," in Richard B. Gaffin, Jr., ed., Redemptive History and Biblical Interpretation: The Shorter Writings of Geerhardus Vos [Phillips burg, New Jersey: Presbyterian and Reformed Publishing Co., 1980], p. 345).

2 "Truth is the foundation in God's own acts and words." notes Gottfried Quell, a notion that is consequent with the general meaning of the term $\Omega y$ in the OT, namely, "Integrity," or "faithfulness," conveying the ideas of rellability, ficmess, stability,

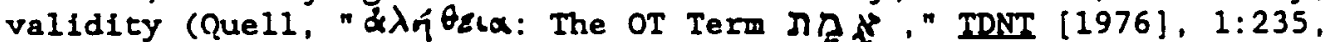
232-33. Cf. Thiselton, "Truth," p. 877). The term is therefore suttable for being used of persons, expressing "that which predomInantly characterises their speech, action or thought" (Quell, $p$. 233). Hence. "when Hosea (4:1) complains that there is no $\pi N^{\prime}$ in the land, by linking the concept with the knowledge of God ( $\left.a^{2} n^{2}\right\}$ ny.]), he maintains the line of thought along which he understands

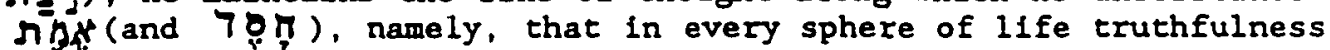
grows out of unerring knowledge of God's will" (1bid., p. 235). In 
relate to the truth in an existential way, 1.e., by listening to the Word of God in the life and message of Jesus.

It should be noted, however, that this is not the only meaning that the word "truth" conveys in the Scriptures. In the Gospel according to John itself the term has also an cognitive dimension. I We could perhaps speak in this case of "truths about" or true statements. In this sense, the Christian approaches truth-. which is expressed through proposictons--intellectually, using his or her reasoning abilities. In effect, Jesus sald that he had "heard" the truth of God, and that he was "telling" the truth to men (John 8:40,45). According to this saying, the truth is something that can be communicated intelligibly, with participation of thought and language. This is the cognitive dimension of truth which we considered earlier in this chapter when dealing with the philosophical theorles.

Beyond the Gospel according to John, other biblical documents ${ }^{2}$ make a similar distinction between truth as a personal

Rabbinic Judaism the word truth follows essentially the same lines as in the OT, writes Gerhard Kittel. "In the first instaise, the word denotes a huran attftude, and on this basis it serves to express a divine mode of being" (Kittel, "dijibela: Judaism," TDNT [1976], 1:237). So, when it is affirmed that "the very essence of God is $\Omega$, . . . it may be said conversely that תọthas its essence in God" (ibid.).

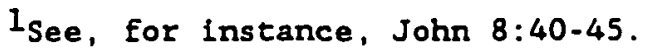

2 In the Johannine writings and, in general, in the NT we find two kinds of "truth, " affirms Geerhardus Vos (see Gaffin, ed., Redemptive History, p. 343). "True," in the sense of veracious, "denotes the agreement of a concept or its expression with the reality reflected in $1 t . "$ This is the "ordinary cognitive meaning of the term" (Ibid., PP. 343-44). The second meaning of true, as exchangeable with verftable, has nothing to do with God's or Jesus' 
attribute, especially identified with the person of God and embodied in Jesus Christ (the "personal" dimension), and truth as conformity of intellect to reality, expressed through propositions (the "cognitiven dimension).

This distinction has been usually described as a contrast between the Hebrew and the Greek mind. 1 Rucolf Bultman. ioilo: this line when he points out that the New Testament's use of the term truth "is partly determined by the Semitic use of $ת \not ̧$ and partly by the Greek and Hellenistic use of $\alpha \lambda \hat{\varphi}^{\theta} \iota \alpha . "{ }^{2}$ He explains that in the usage of the NT, truth refers sometimes to "that 'on which one can rely' (In the sense of $ת \not \leftrightarrow x$ )" and thus stgnifies

telling the truth. This second meaning is related to the affirmation that Jesus is the truth, which means that "the supreme reality of the things that compose His character is incarnate in Him. The fulness of 'truth,' which . . . resides in the Only Begotten, must mean far more than the rellability pertaining to His words" (ibid.. pp. 344-45). Truth understood in this sense denotes Jesus' essence as assoclated with heaven, observes Vos (Ibld., pp. 345-46). For more scriptural examples of "truth" conveying the meaning of correspondence with facts, see below, p. 272, and the note 6 on the same page.

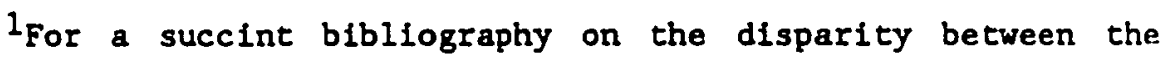
Semitic and the Hellenistic ways of understanding the essence of rruth, see above, p. 101, n. 1 .

2Bultmann, "dińfeca," IDNT (1976), 1:238. It is commonly held that the Semitic and Greek minds are rathe: different. Eduard Schwelzer, for instance, elaborating on the matter of the Continental-European background of modern theology points out that the Western man is interested in answering the question, "What is ihfs?," whereas a Hebrew or an Orfental is more interested in questions like, "What has happened?. What did he do?, Whe dic that?" (Eduard Schweizer, Luke. A Challenge to Present Theology (Atlanta: John Knox Press, 1982], p. 23). So, the common view is that the Greek concept of truth relates to the "ultimate reality" of the objects that we percelve, while the Hebraic concept of truth denotes the "rellability" and "falthfulness" of, for instance, God's acts in human history. 
"reliability" or "trustworthiness."l But on other occasions, he notes, truth implies the "real state of affairs" in the Greek sense (he cftes as example John $8: 40,45 E),$.2 as well as "truth of statement" (Acts 26:25) and "true teaching or faith" (2 Cor 13:8). ${ }^{3}$

This approach is questioned oy Thiselton, ${ }^{4}$ who criticizes what he regards as "a tendency in biblical studies to overgeneralize about the uses of alethela and alethes in classical Greek," 5 partly with the purpose of drawing "an unduly clear-cut contrast between the Greek and Hebrew concepts of truth." 6 In

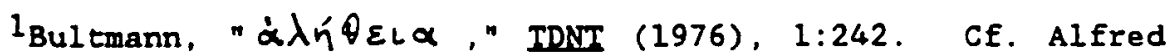
Jepsen, "'emeth," TDOT (1974), 1:313: "Rellability would be the best word in English to express the ldea suggested by the yebrew term used in the OT."
}

$$
\begin{aligned}
& \text { 2Bultmann, " } \dot{\alpha} \hat{y} \theta \varepsilon l \alpha, " \text { p. } 243 . \\
& \text { 3Ibid., p. } 244 . \\
& 4 \text { "Truth," NIDNIT (1986), 3:874-75, } 884 .
\end{aligned}
$$

5Ibid., p. 874. Thiselton points out ("Truth, " p. 875) that the traditional claim of nineteenth- and twentieth-century biblical scholarship regarding the concept of truth in classical Greek is valid up to a point. According to that claim, for the Greek way of thinking, "truth" denotes reality in contrast to mere appearance, hence belonging to the timeless, supra-material, and extrahistorical realm. Thiselton concedes that aletheia does indeed mean truth in contrast to mere appearance in much of Greek philosophy, particularly in Parmenides and Plato, but he observes that other views, such as those of the Sophists and Aristotle, hold a more positive relation of truth to the material world. He also cites examples of the use of alethela in the sense of honesty and reliability in Homer, in the sense of standing in oppostition to falsehood in Herodotus, Thucydides, and later Hellenistic writers, and in the sense of that which corresponds to the facts of the matter in Homer, Philo, and Josephus.

"Although it cannot be denied that "truth" for the Semitic mind, and thus in the OT, has much to do with the ideas of faithfulness, firmness, and rellability, we cannot either set aside Thiselton's observation that, "In perhaps three passages in the Psalms (Pss $43: 3 ; 45: 4 ;$ and $51: 6$ ) truth stands in contrast to concealment, 
particular, he affirms that Bultmann "too readily speaks of 'the Gk. use' of alethela as over against 'the Semitic use' (IDNT I 238)."I Thiselton also finds questionable the claim that in the Johannine usage of the term there is a fusion of the alleged Hebrew and Greek concepts of truth. ${ }^{2}$

What does seem clear, however, is that the term conveys, both in John and in the Scriptures in general, the Idea of falthfulness or rellability and that at times it denotes the truth of propositions as well.

Even though classical Protestant Scholasticism is not totally different, Mackinnon observes that "no group within the Christian tradition has ever lald as much stress on the truth of propositions as Roman Catholicism." 3 This fact must be seen in connection with the Catholics' emphasis upon the definition of doctrines and their insistence on the necessity of the bellevers' acceptance of the truth of these doctrines in order to remain in the church as members in good standing.

almost in a sense which many scholars claim to find exclusively in Greek Ifterature" (Thiselton, "Truth," pp. 880-81). Furthermore, Iniselton observes that in Prov $23: 23$ to "buy the truth" can hardly refer to falthfulness or rellability (1bid., p. 880). He suggests that "what can be 'acquired' is knowledge of the true facts of the matter" in contrast to either false or partial information (ibid.; emphasis supplied). The infuction in Prov 23:23 is to obtain discipline or, in general, Instruction and education (see Robert $B$. Y. Sco - Proverbs-Ecclesiastes, The Anchor Bible 18 [Garden City, New York: Doubleday, 1965], p. 143).

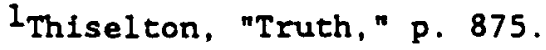

${ }^{2}$ Cf. ibid., pp. 874-75.

3 Mackinnon, Truth and Expression, p. 132. 
The notion that truth is eternal and that it can be expressed through clear propositions are two premises which give logical support to the Roman Cathollc claim of the infallible formulation of 1 ts dogmas. 1 As tt shall be shown later, Küng's notion of truth is aimed at questioning the philosophical support for the doctrine of the infallibility of the Roman Catholic magistertum.

Küng's Concept of Truth and Infallibility

Hans Kung has been described as a theologian with "a passion For truth." 2 He himself asserts his deep and central concern for

IOn this matter, see Pope Plus XII's Encyclical Humani generts (Aug. 12, 1950), especlally articles $29-34$ which deal with errors in the field of philosophy which are current among Catholics. This Encyclical teaches: "It is well known how highly the Church regards human reason, for it falls to reason to demonstrate with certalnty the existence of God, personal and one; to prove beyond doubt from divine signs the very foundations of the Christian faith; to express properly the law which the Creator has imprinted in the hearts of men; and finally to attain to some notion, indeed a very frultful notion, of mysteries." That "sound philosophy which has long been. . . a patrimony handed down by earlier Christian ages, and which moreover possesses an authority of even higher order, since the Teaching Authority of the Church. . . has weighed its fundamental tenets, . . . safeguards. . . the and'3 abllity to attain certain and unchangeable truth" (art. 29). "How deplorable It is then that this philosophy, recelved and honored by the Church, is scorned by some, who shamelessly call it outmuded in form and rationalistic. . . . Our traditional philosophy, then, with its clear exposition and solution of questions, its accurate definition of terms, its clear-cut distinctions, can be, they concede, useful as a preparation for scholastic theology, a preparation quite in accord with medieval mentality; but this philosophy hardly offers a method of philosophizing suited to the needs of our modern culture. They allege, finally, that our perennial philosophy is only a philosophy of immutable essences, while the contemporary mind must look to the existence of things and to life, which is ever in flux" (art. 32).

${ }^{2}$ Notice the title of Robert Nowell's book, A Passion for 
the Integrity of Christian truth. 1 It is in the context of this passion for truth that his preoccupation for what he regards as serious errors of the Roman Catholic Magisterium must be understood.

Past errors of the ecclesiastical teaching authorfty can no longer be concealed, 2 holds kung, nor explained away with the argument that they were not errors but incomplete perceptions of truth, or inadequate formulations of doctrine due to the ambiguity and historlcal mutability of human language. 3 The argument used on not a few occasions--especially when the error of a pronouncement could no longer be denied--that that pronouncement was neither an ex-cathedra statement nor a dogmatic teaching, and hence not infallible, is no longer convincing. ${ }^{4}$ In dealing with the problem of magistarlal errors, the essence of Kung's thesis is that the faith

Iruth: Hans Küng and His Theolegy (New York: Crossroad, 1981).

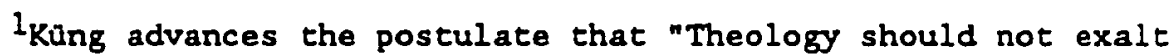
simple faith nor defend an 'ecclesiastical' system but strive for the truth without compromise in intense scholarly fashion" (Küng, "New Consensus," p. 13). This is principle No. 2 of his "ten guiding principles for contemporary theology."

${ }^{2}$ Küng observes that, in fact, what might be called "classical errors" of the ecclesiastical Magisterium are now "largely admitted" (Infallible?, p. 31).

${ }^{3}$ So "Declaration of the Conference of German Bishops," February 4, 1971 (See Küne Dfalorue, p. 40).

${ }^{4}$ See the examples pointed out by $E$. L. Mascall in his The Recovery of Unity: A Theolocical Approach (London, New York, and Toronto: Longmans, Green and Co., 1958), pp. 221-29. Regarding Kung's use of the Encylical Humanae vitae as a contemporary example of erroneous pronouncement, many have observed that the teaching of that encyclical as well as the teaching of Popes Pius XI and PIus XII on human contraception were not intended as dogmatic formulations (see, for Instance, Karl Rahner, "A Critlque of Hans Küng Concerning the Infallibility of Theological Propositions," HomPasR $71[1971]: 12)$. 
of the church does not depend on infallible propositions. 1 His usual line of argumentation--espectally in the volume Infalibible?-consists in exposing, first, the problems of propositions in general. Then küng applies his conclusions to both the church's dogmatic statements and to the words and sentences of the Scriptures, in that order.

The philosophical and scriptural backgrounds presented earlier in this chapter shouid prove helpful in considering Küng's plea for Christian truth. Regarding truth as such, we are especially interested in his attitude toward the two aspects which have been labeled the cognitive and the personal dimensions of truth. My reason for this should be easy to appreciate once ine analysis of Kung's arguments is made.

Truth as a quality of being: The personal dimension of truth

"What is truth?" is a question explicitly raised by küng in his book The Church-Maintained in Truth. ${ }^{2}$ His answer tries to make

InChristian faith is not a closed, quasi-mathematical system of propositions, as a theology infected with rationalism tried to make 1t, so that it ceases to be true as soon as one of the propositions is found to be incorrect (hence up to a point the anxiety to make sure that all propositions are correct)" (Küng, Malntalned, p. 46). The faith of the church "is indeed dependent on propositions if it is to be expressed, but it need nun be destroyed by false propositions" (lbid., p. 66). "It has not been proved that En t: ependent on infallible propositions" (Infallible?, pp. isoff.).

${ }^{2}$ Küng, Maincalned, p. 15 . The orfginal edition Kirche-. gehalten in der Wahrheit? was published in 1979, nine years after the first edition of the German original of Infallible? These two books, as well as portions of Dees God Exist? (1978), are the main sources for analyzing Küng's views on truth and infallibility. Maintained is also important from the perspective that it was the 
It clear from the beginning that truth means "more than true, or correct, propositions or statements."1 Since küng is basing the main assertion of this volume--namely, the indestructibility of the church in spite of secular prophecies to the contrary ${ }^{2}-$ on the theological justification given by the message of the Scriptures as whole, 3 his notion of eruth, particularly of the truth of the church, is to be drawn from the pages of the Blble. In the biblical sense, Küng observes, truth means "fidelity, permanence, jellablli. ty: the absolutely rellable fidelity of the God of the Covenant to his word, to his promise, and so to us."4 He affirms divine truth to be a quality of the being of God rather than the real state of affalrs as seen from, say, "God's Eye point of view." 5

only one of his volumes specifically cited by Vatican authorities in support of their action against him by which they stripped him of his mandate to teach Roman Catholic theology. The English translation includes a poscript written after the Vatican censure, "Why I Remain a Cathollc," in which kung responds to the formal accusation of having departed from "the integral truth of the Cathollc falth."

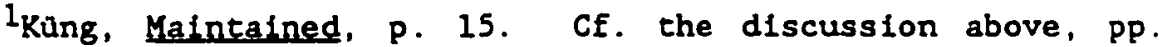
292-93. Elsewhere Küng emphasizes that "truth is not the same as facticity and in particular not equivalent to historical truth" (Being Chrtstian, p. 415).

2Maintained, pp. 9-11.

3Ibid., pp. 11-12, Kung is willing to listen to "the basic conviction running through all the New Testament writings" (ibid., p. 12).

${ }^{4}$ Kün, Maintained, p. 15. cf. Infallible?, pp. 220-21.

'What is between quotation marks is not Küng's but Putnam's wording (Putnam, Reason. Truth and History, P. 49). Küng further explains his position: "This is the truth of God: the absolute fidelity and reliability of God in regard to humankind, of a God who does not decelve himself or us; who never becomes a liar, however often he is cheated; who never refuses fellowship, even though it is 
Küng's interest in stressing the personal dimension of truth can be understood, in part, from the standpoint of the purpose of his book Maintained. Here he states that his Intent is to present a "theological meditation" upon the Christian message by means of which he attempts, as far as possible, to make intelligible "the persistence of the Church in truth despite all errors," while at the same time "considering fully the numerous practical consequences" 1 included in such a statement. The concept of truth which emphasizes its personal character over agalnst the cognitive, propositional one allows our author to maintain without logical contradiction that the church can remain in the truth even when it may be mistaken in some of its doctrinal formulations.

In addition to this emphasis on the personal dimension of the nature of truth, Küng elaborates on the humanity of the members of the Magisterium, 2 a humanity which affects their magisterial task. He contends that all the human beings who form the church may misunderstand to some extent the revelation of God. They may make mistakes, notes küng, because to err is as ecclesiastical as it is human. "To err--as we have recently added--is papal: simply because

constantly broken; who does not allow those who lapse to fall away forever. It is from this truth, fldelity, and reliablitty of God that the believer and the belleving community can, should, and may liven (Kung, Maintained, Pp. 15-16).

1Maintained, p. 7. This was also the essence of Kung's thesis in Infallible? (1970): "The Church w11l persist in the truth IN SPITE OF all ever possible errors!" (p. 175). This idea is repeated several times with slight variations in this book.

p. 29 .

2This is so as early as 1962. See his volume May Believe. 
Church and pope are also human and remain human. 1 To those uneasy at the thought of magisterlal errors, Küng replies that "there is no need at all for panic."2 Error on the part of the eccleslastical teaching office "in serlous definitions of falth or morals is in any case a fact--and we are still alive, ${ }^{3}$ he remarks.

Again, Kung's point is that though the church may have been wrong in the past 4 --as it can be today--in some of its teachings, policies, or actions, this does not necessarily mean that it no longer remains in the truth and, therefore, has no significant role to play in the modern world. Its remaining in truth depenos primarily on God's graclous promise 5 and, hence, on the shurch's permanent attitude of trust in God.

Infaliblele?. p. 186 .

2 Maintalned, p. 33 .

${ }^{3} \mathrm{Ib} 1 \mathrm{~d}$.

4nThe Church of Christ... Is certainly not distinguished from other human organizations by the fact that there is no error in her or that in her there is less or less great error, or that at least in certain flelds [we may understand "matters of falth"], with certain persons [we may understand "the bishops with the pope"] or in certain cases (we may understand "ex cathedra pronouncements of the pope] there is no error. One merely needs to run through once again the brief list of examples of error with which we introduced our first chapter or perhaps the Index of forbidden books to agree" (Kung, infallible?, p. 186). For the referred "list of examples of error," see ibid., pp. 31-33.

SWrites Kung: "The Church is distinguished from other human organizations. . . only in the fact that the promise is given to her as to the community of those who believe in Christ: that she will survive all wrong conclusions and mis-hits and also all sins and vices;. . . that in her the message of Jesus Christ will endure; that thus Jesus Christ himself will remain with her in the Spirit and thus keep her through all errors and confusions in the truth of Christ" (Infallible?, p. 186). 
Finally, his emphasis on the personal nature of truth leads Küng to affirm that the truth of the Scriptures "means more than simply truth as conformity of intellect with reality." I This view enables him to reconcile what he regards as errors in the Scriptures with their faithrul presentation of the gospel of Jesus Christ. "A deviation from the truth in historlcal and sclentfic questions in no way endangers the acthority of Scripture, 2 resserks Küng. Just as the church remains in the truth in splte of its particular errors, so the Bible falthfully attests the truth of the gospel in splte of its errors in some single statements. It is his conclusion that "Just as there is no a prforl infallible teaching offlce, so there is no a prtort infallible teaching book in Christendom. "I The eruth of the Scriptures means in the last resort "truth beyond all truse propositions." 4 as the term is used in both the OT and the NT. King Insists, truth means "over and above the truth of words and sentences, Eldelity, constancy, reliability: the fldelity, that is, of the God of the Covenant to his word and to his promise." 5

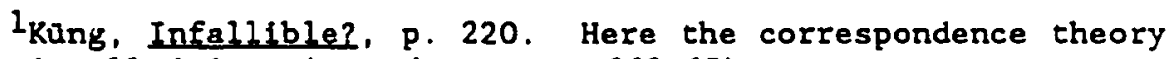
of truth is alluded to (see above, pp. 262-65).

2Ibid., p. 213. "Frreors of the Bible in natural science and history" can even help us to perceive--"not worse but better," thinks kung--through all the temporal relativity of its words, the real intention of God's revelation: "God. . . writes stralght even on crooked Iines" (ibid., p. 219).

3Ibid., p. 219. I shall return to the issue of the Infallibilty of biblical statements (see below, pp. 292ff).

${ }^{4}$ Ibid., p. 220.

5Ibid., pp. 220-21; emphas is in the original. 
Truth as propositional: The cognt: Eive dimension of eruth

Does all this mean that Küng denies all objective, cognitive dimension of truth? Are we to regard truth merely as a quality of being, never understanding it as conformity of Intellect with reality and expressed through propositions?

The question may be answered by reflecting, first, on Küng's concept of "error", 1 the category that is logicaliy the opposite of "truth." This methodological approach is suggested not only by Kung's explicit use of the antithesis "error-truth" with respect to

It is the opinion of Karl Rahner that in Infallible? Küng has not developed an adequate theory of error, 1.e., that he has not considered the difference between error and statements which, though inadequate and historically limited, are in the final analysis not wrong (see Rahner, "Kritlk an Hans Küng," Stf2t 186 [1970]: 361-77; Eng. trans. by Kenneth Baker, "A Critique of Hans Küng: Concerning the Infallibility of Theological Propositions," in HompastR, May 1971. Pp. 10-26; see In particular Pp. 17, 22, 25; hereafter referred to as Rahner, "A Critique"). States the German theologian: "Küng should have been able to develop a theologically deeper and more radical concept of truth in order to say what 'error' in theology really means. He really had the obligation to do this in his research" (Rahner, "A Critique," p. 22). However, as Küng also observes, Rahner recognizes that "a theory truly satisfying. . . of how error on the one hand and historical finiteness, inadequacy and misunderstandability of a human proposition on the other hand can be exactly distingulshed, does not yet exist" (ibld., p. 18; for Küng's observation, see his "Im Interesse der Sache: Ancwort an Karl Rahner," In Sti2t 96 [1971]: 43-64; trans. Kenneth Baker, "To Get to the Heart of the Matter: Answer to Karl Rahner," in HompastR, June 1971, p. 24). Though Rahner demands of Kung what nobody has accomplished, Küng grants that "obviously it would be a good thing to give more thought to error than I was able to do within the limits of my book" (Küng, "To Get to the Heart," p. 25). He points out, however, that "from the first page to the last one the book says a great deal about error, to Rahner's chagrin" (1bid., p. 24); then he adds: "I have not the slightest intention of providing a 'theory of error' developed elther by the scholsstics or by Rahner himself," i.e., to rescue some a frlori infallible propositions of the Magistertum "which apparently cannot stand up under the concentrated fire of exegetical, historical, philosophical and theological criticism" (ibid.). 
the tradition of the church ${ }^{1}$ but also, and espectally, by his claim thaci lite ilüurte. has committed both factual and propositional errors. ${ }^{2}$ obviously, if there were no possibility of expressing truth propositionally, there would be no possible propositional error elther.

It is Important for the understanding of Küng's concept of truth-error to inquire about the "classical errors" of the ecclesiastical Magisterium. Besides, why does he consider them to be errors? ${ }^{3}$ In ascertaining Kung's criteria of error we may at the same time, by implication, come to a clearer understanding of what his criteria of cognitive truth are.

In the first chapter of his volume Infallfble? ${ }^{4}$ and the third one of Maintained, 5 kung provides us with an answer to the

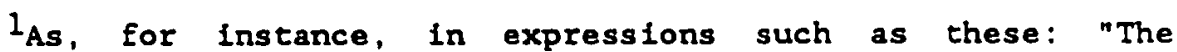
persistence of the Church in truth, despite all errors" (Malntained, p. 68), and, "In the last resort the Church does not live by its errors but by the truth of the gospel, which is able to prevail even alcngside numerous and serfous errors" (Ibid., p. 35).

2 "The errors of the ecclesiastical teaching office are numerous and serlous," remarks kung (Infallible?, p.31). He presents a list of what he labels "classical errors" of the church's Magisterium (ibid., pp. 31-33).

${ }^{3}$ Kung himself ralses a similar question as to why some statements should be coisldered to be true. "Even according to the usual teaching"-he says-."dogmas are not true because they have been defined; they are defined because they are true. Why then are they true?. . . What then is the criterion to be if we have to ailow for errors on the part of the ecclesiastical magisterium.. . ?" (Küng. Mafntained, p. 39; emphasis his).

$$
\begin{aligned}
& { }^{4} \text { See pp. 31-32. } \\
& { }^{5} \text { See pp. } 33-35 .
\end{aligned}
$$


first question. As cited there, 1 here is a list of the classical errors of the Catholic Magisterfum: (1) the excommunication of Photius, ${ }^{2}$ (2) the prohibition of interest at the beginning of modern times, $^{3}$ (3) the condemnation of the scientific theory of Galileo, 4 (4) the condemnation of new forms of worship in the Rites controversy in India, China, and Japan, ${ }^{5}$ (5) the definition of the Council of Trent on the transmission of original sin through procreation, 6 (6) the definition of the same council on the sacramental character

1The examples numbered (1) through (4), and (9) through (11) in my list proceed from Infallible?. The numbers (5) through ( 8 ). and (12) are mentioned in Maintained. $C f$. the errors mentioned in May Belleve, pp. 30.

2Photius (c.820-891), Patrlarch of Constantinople, was condemed and excommunicated by Popes Nicholas I (863) and Adrian II (869-70) in the midst of the theological and political conflicts between Rome and Byzantium. Later. Pope John VIII recognized the rehabilitation of Photius $(879-80)$ and demanded in return the latter's recognition of papal primacy, which he did, though not without defending the autonomy of the Greek church (see F. Dvornik, "Photlus, Patriarch of Constantineple, "NCathEnc [1967], 11:326-29). kung notes that the excommunication of Photius made formal the schism with the Eastern Church, a schism which regretfully is now almost a thousand years old (Infallible?, p. 3I).

${ }^{3}$ The ecclesiastical Magisterium changed its mind on this matter after a varlety of compromises, but much too late, remarks Küng (Infallible?, p. 31).

${ }^{4}$ The condemnation of Galileo and the measures adopted as a consequence of this action are essentially responstble for the estrangement between the church and the natural sciences, observes Küng, an estrangement which has not yet been overcome (1bid., pp. $31-32)$.

${ }^{5}$ This condemnation is one of the main reasons for the largescale breakdown of the Catholic missions of modern times in those nations, states küng (ibld., p. 32).

6 "Decree on Original Sin," June 17, 1546 (see Denz, 790, 791). 
of ordination as an indelible mark on the soul, 1 (7) the solemn condemnation (understood in a dogmatic sense) of freedom of religion and conscience, (8) the proclamation in church documents of the complete inerrancy of the Bible, ${ }^{2}$ from the time of Galileo to the twentieth century, (9) the maintenance, up to the First Vatican Council, of the secular power of the pope, (10) the numerous condemnations, at the beginning of the twentieth century, of the methods of critical-historical exegesis, 3 (11) in the dogmatic fleld, the condemnations of "Modernism" (mainly the theory of evolution and the historical-critical conception of development of dogma ${ }^{4}$ ) and those included in the encyclical Humant generis, 5 and

InCanons on the Sacraments in General," March 3, 1547 (see Denz, 852); and "Canons on the Sacrament of Order," July 15, 1563 (Denz, 964).

${ }^{2}$ For instance, Pope Leo XIII (1878-1903), in his Encyclical Providentissimus Deus (Nov. 1893), affirmed: "So far is it from the possibility of any error being present to divine inspiration, that it itself of itself not only excludes all error, but excludes it and rejects it as necessarlly as it is recessary that God, the highest Truth, be the Author of no error whatsoever" (see Denz, 1951).

In perticular, the historical-critical epproach to the authorship of the books of the Bible, to source criticism in the OT and NT, to historicity and literary forms, to the Comma Johanneum, and to the text of the Vulgate (Infallible?, p. 32).

\footnotetext{
${ }^{4}$ For the historical-critical conception of development of dogma, see above, pp. 91-94.
}

Issued August 12, 1950, Humant generts deals with "some false opinions threatening to viukimfise the foundations of the Catholic doctrine." (For the complete text of this Encyclical, see National Catholic Welfare Conference, Selected Documents of His Holiness. Pope Rius XII (Washington, D.C.: Merkle Press, n/d]). The Encyclical addresses some errors current outside the Catholic church, such as evolution as an explanation of the origin of all things, existentialist philosophy, and historicism (arts. 4-6). Articles 9-39 deal with errors current among Catholics. They are described as errors in the fleld of theology (arts. 14-28), 
(12) modern definitions of faith or morals such as Paul VI's on birth control in the encyclical Humanae vitae.

Even a cursory analysis of Küng's argumentation suggests that the answer to the second question--namely, why such actions, pronouncements, and definitions are to be considered ds errors.. appears rather obvious: They do not agree either with scientific truth $^{1}$ nor with the original Christian message. ${ }^{2}$ The view that Küng's main criterla of Christian truth are both the gospel of Jesus Christ and the modern historical-scientifical conception of reality seems clearly confirmed. ${ }^{3}$ In other statements, Küng denounces as

philosophy (arts. 29-34), and those stemming from the positive sciences (arts. 35-39). Sallent among them are the consideration of the Church's Magisterium as "an obstacle in the way of science" (art. 18), putting forward the opinion that "Immunity from error extends only to those parts of the Bible that treat of God or of moral and religious matters" (art. 22), the attempt to interpret the Scriptures "by the purely human reason of exegetes" without taking account of the Tradition of the Church (art. 22), doubting "the necessity of belonging to the true Church in order to attain eternal salvation" (art. 27), the claim that scholastic philosophy (the method of Aquinas) upholds "the erroneous notion that there can be a metaphysic that is absolutely true" (arts. 31-32), the defense of "polygenism" (art. 37), and so on.

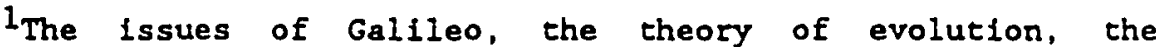
complete inerrancy of the Bible, and modern historical-critical exegesis, for instance.

2Thus, Kung declares that the Council of Trent's definition on the sacramental character of ordination as an indelible mark on the soul "cannot be justifled in the light of Christian origins" (Maintained, p. 33).

3We may conclude that, in general, the reason why Küng regards these teachings and actions of the Magisterium as errors is because they do not "correspond" to reality as modern man perceives 1t, or, In some cases, because they are not "coherent" with the criterion for "what is supposed to be true in the Christian Church," namely, "the Chrifiliall message, the gospel of Jesus Christ as originally recorded in the NT. . . and thus Jesus Christ himself" (see Küng, Maintained, p. 40; emphasis in the orfginal). 
errors those pronouncements or decisions which have proved to have negative "practical" consequences. 1

It should be obvious that the correspondence, coherence, and pragmatic theories of truth are all implied in Küng's citierla to identify errors made by the ecclesiastical Magisterium. As to the nature of truth as such, this would mean, by implication, that for him--even though he does not explicitly say so--truth is not only personal, a quality of the being of God; it has also an intellectually verifiable dimension.

Indeed, though he stresses the personal dimension of truth, Kung is careful not to exclude the possibility that truth may mean, at times and even in the biblical usage, correct propositions or statements. Thus, when he discusses "truth in the Scriptures," he does not claim that it "cannot" mean true propositions or conformity of invellect with reality. What he affirms is that, biblically speaking, truth means "essentally more than true, or correct propositions." 2 In order to exclude any misunderstanding, Küng

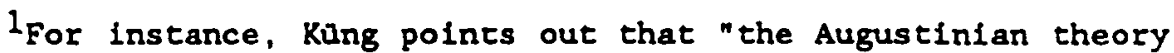
of original sin as transmitted by procreation" has had negative consequences "in regard to the disparagement of sexual pleasure and in regard to the salvation of unbaptized children" (Maintained, $p$. 34). Similarly, he sees the doctrine of the inerrancy of the Bible as having had negative consequences for "the Church's attitude to the natural sciences and history." The condemnation of freedom of consclence and religion has been ominous "for many persecuted Protestants and for the position of Catholics in modern soclety" (1bid.. p. 35). One could, perhaps, also include in this category the Photius affair which made formal the unfortunate thousand-yearsold schism with the Eastern Church (see Kung. Infallible?, p. 31).

${ }^{2}$ Küng, Maintained, p. 15 ; emphasis supplied. Cf. Infallible?, p. 220: "Truth of Scripture. . means more than simpiy truth as conformity of intellect with reality." 
explicitly states that he does not mean that propositions "cannot correspond to the reality which they claim to express."1 on the contrary, he concedes that propositions--"of which the Church's Eaith has to make usen2--even though problematic in nature ${ }^{3}$ are capable of stating the truth. 4

Finally, it should be noticed that the very possibility of expressing truth by means of propositions is what allows küng himself to expose his views meaningfully. As Karl Rahner observes

Isee Infallible?, p. 161. This means that Küng does not discard the validity of the correspondence theory of truth, at least not completely. Karl Rahner, however, points out that in his volume Infallible? Küng comes into conflict with the traditional understanding of propositional truth as "the conformity of the mind to the thing." According to Rahner, the relevance of theological propositions resides in the fact that the "real thing" of the theological proposition "is ultimately the self-communication of God in grace to men; on the one hand this self-communication makes its historical appearance in Jesus Christ and on the other hand is received in the radical acceptance of human existence (called faith, hope and love)." Propositional truth is not, Rahner remarks, just "a supplementary image of the original truth and reality, which itself remains unimportant and extrinsic to this 'raal' truth, even when both arc not identical" (Rahner, "A Critique," $p .22$ ).

2Infallible?, p. 158. See also ibid., P. 157: "Articles of faith are propositions. Formulas of falth, professions of faith, are propositions." Propositions of faith, though .ot directly God's word, are "God's word attested and mediated by man's word: perceptible and transmissible by human propositions."

${ }^{3}$ Ibid., pp. 157-62. Küng's explanation of the problematic nature of propositions in general is presented in some detail below, p. 289, n. 5 .

${ }^{4}$ Ibid., p. 161. I return to the issue of propositions when we further discuss Kung's view regarding the infallibility of both the dogmas defined by the ecclesiastical Magisterium and the statements of the Scriptures. See the following discussion, especially pp. 292-98 below. 
in his reply to Küng's view on infallibility; if there were no truth of propositions (i.e., no propositions which are incontestably erue), Küng's assertions themselves that "the church remains in the eruth in spite of all errors," for instance, would be "subject to the verdict rendered on propositions as such."I In effect. Küng would have fallen in his own trap had he affirmed that propositions are incapable of stating the truth, which, as already pointed out, he does not. 2

\section{Iruth is dynamic: The fallibility} of eropositions

Even though our author acknowledges that truth does have a cognitive dimension, as we have just discussed, he opposes any attempt to totally intellectualize its nature. 3 This is consistent with his view that truth, particula:l\% in theuiogy, has primarily a personal and existential dimension. Küng's position may be summarized in his assertion that theological statements cannot have the precision of mathematical eruths. 4

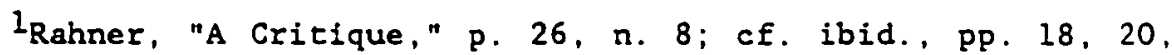
21. "Man lives in the truth only by means of true propositions," remarks Rahner (ibid., p. 18).

${ }^{2}$ See Küng, Infallible?, p. 161; cf. ibid., p. 220: "Even though there are no propositions in the Bible which are a priori frae from error, nevertheless there are in fact true propositions attesting the gospel" (emphasis in the original).

${ }^{3}$ Ibid. , pp. $162-69$.

${ }^{4}$ It must be noticed that Küng's thesis is at odds with the Catholic striving for expressing dogmas through precise definitions (see above, PP. 273-74, especially the quotation from Humani generis). 
It is, in fact, one of Küng's main contentions that theological propositions-for instance, his own thesis that "the church will remain in truth despite all errors"--cannot be scientifically verified. They are not based on evidence that we can observe. Nor are they demonstrable by pure reason as in mathematics. They are truths of faith. 1

Karl Rahner sharply criticizes küng at this point, charging him of "pietistic invocations" and "hymnic protestation."2 The Jesuit theologian makes the point that even "truths of faith" must be expressed in propositions which are true if they are to exist at al1. ${ }^{3}$ In defense of küng we should recall that he does not deny this. In fact, he declares that the church's faith has to make use of propositions, ${ }^{4}$ which, even though not free from tine problematic of propositions as such, 5 are by no means incapable of stating the

\section{Infallible?, p. 187 .}

${ }^{2}$ Rahner, "A Critique," p. 26, n. 8 .

${ }^{3}$ Ibid., pp. 18-21. Such propositions do exist, remarks Rahner, and if küng were to deny it, "then one could speak with him as one would with a skeptical philosopher" (ibid., p. 20).

${ }^{4}$ Küng, Infallible?, Pp. $157-58$.

In Küng's view, the problematic inherent in propositions as such includes the following five points: (1) Due to the fundamental inadequacy and deficiency of human language, propositions always fall short of reality. (2) Propositions are open to misunderstanding. This, again, is due basically to a linguistical inadequacy: the fact that words have different, fluid, often ambiguous meanings. (3) In translating from one language to another, propositions can be rendered only up to a point. Play upon words, for instance, can rarely be preserved in translation. (4) Since language is not a static shape but a dynamic event, propositions are always "in motion." Words and sentences can radically change their meaning in a new situation. (5) Propositions are ideology-prone. As in advertising, where words and sentences are at times nused, abused, 
truth. 1 Elsewhere he insists on the notion that even though propositions of falth, like all propositions, are prone to ambiguity and confusion, they obviously can be "true or false." 2

I have noted that in his attempt at coping with the problem of error in the Catholic Magisterium, 's while still affirming that the church remains in truth, Küng distinguishes between an existential "remaining in the truth" and the "truth of propositions. $" 4$

Regarding the specific issue of the truth of propositions, Küng stresses two points: (1) No proposition is a priorit infalible, Incapable of error. 6 Once again, this does not mean

and exploited," a particular ideology too may make cinem say the very opposite of what they originally meant. As examples, Küng mentions "democracy," "freedom," and "order" (see Infallible?, pp. 158-61).

I Ibid., P. 161 .

2Ibid., p. 169; emphasis is Küng's. See also p. 170.

3nThe errors in the Church must be acknowledged. No critically thinking person can fall to see this," remarks Küng (Infallible?, p. 174; emphasis his). To be true, even Rahner, who sharply criticizes Küng's book on infallibility, acknowledges that "there has been and today certainly still is much error in the Church and in her theology. . . . This error is also amalgamated much more than one usually thinks with truths and dogmas of the Church" (Rahner, "A Critique," p. 23).

4This is the principal thesis of his volume Infalifble?, as can be seen from its pp. 173-78. On Küng's distinction between existential and propositional truth (which I call the "personal" and the "cognitive" dimensions, respectively), see above, pp. 276-81.

5 Küng explains what he means by propositions which are a priort infalible: they are "sentences, propositions, definitions, formularies, and formulas, which are not only de facto not erroneous but in principle simply cannot be erroneous" (Infallible?, p. 150; emphasis his).

${ }^{6}$ Lutheran theologian George A. Lindbeck observes that at the 
that Küng denies to every proposition the possibility of expressing the truth. What he is questioning is the claim of the Roman

core of Kung's thesis is the idea that infallible propositions do not exist. If the Roman Catholic Magisterium is incapable of producing infallible propositions, it is "simply because there are no such things" ("Hans Küng's Infallible? An Inquiry: A Symposium. III: A Protestant Perspective," in America 124 [1971]:431). Though he finds Küng's conclusion admirable, Lindbeck points out some weaknesses in our author's argumentation. One of these is due. in Lindbeck's opinion, to the fact that "Küng has been betrayed by the equivacity of the German word 'Satz'--which means both sentence and proposition" (ibid., p. 432). As for "propositions" and "sentences" or statements, a differentiation can be made, philosophically, between them. Arcording to some philosophical theories, a proposition is an abstract object that serves as "the intentional object of mental acts." Another theoretical assumption sees propositions as "meaning of sentences." Propositions and sentences are thus seen as two separate and distinct things, namely, as "the what-is-said" having an independent reality, and "the declarative speech act" as such, respectively (see Richard M. Gale, "Propositions, Judgments, Sentences, and Statements," The Encyclopedia of Philosophy [1967], 6:494-504). In this way, a proposition could be defined as "that which is expressed by a typical indicative sentence" (Antony Flew, ed., A Dictionacy of Philosophy (London: Pan books and The Macmillan Press, 1979], p. 27ij).

This differentiation between proposition and sentence makes it possible to assert that different sentences can express the same proposition. Conversely, it is also possible for two instances of the same sentence (for instance, when uttered by two different persons) to have different meanings and thus express different propositions (see Gale, "Propositions," p. 500). Lindbeck's observation seems to suggest that küng would be better off if he dealt with the ambiguity and fallibility of statements ("written" propositions or sentences) rather than with the errancy of concepts as such ("mental" propositions). In a personal letter written to Kung, I asked him about his meaning of the word "Satz," specifically "In the context of your discussion of the infallibility of propositions in your Unfehlbar?" "Letter of Enrique Espinosa to Hans Kung, May 14, 1987. This letter may be found in the Adventist Heritage Center, James White Library, Andrews University, Berrien Springs, Michigan). In particular, I asked Küng whether he was speaking of the errancy of both written and mental propositions, in view of the possibility of translating "Satz" either as "sentence" or "proposition." Küng's answer makes it clear that, in principle, he does not differentiate between proposition and sentence: "Im Prinzip würde ich keinen Unterschied machen zwischen 'proposition' und 'sentence'" ("Letter of Hans Küng to Enrique Espinosa, June 2, 1987," also housed in the Adventist Heritage Center of Andrews University's James White Library). 
Catholic Magisterium that some of its pronouncements (specifically its dogmas--conciliar teachings and ex cathedra definitions) are guaranteed by the assistance of the Holy spirit to be free from error ${ }^{1}$ even before being pronounced. $\hat{\imath}$ Indeed, it is important that in dealing with Küng's questiuning of the infallibility of both magisterial and biblical statements his understanding of "infallibility" be clearly elucidated. He finds it difficult to accept that the apostles, for instance, claimed "an infallibility in the textbook sense (impossibility of error)." 3 He refuses to attribute infallibility, in the sense of "incapacity of error," 4 to anyone but God alone. As to "infallible propositions," he explicitly declares that by that expression he means "statements which must be considered as guaranteed a priori to be Eree from error." i.e., propositions which are "not only de facto not erroneous," but "in principle simply cannot be erroneous." 5

His thesis is that in fact all statements, including those pronounced by the Magisterium as well as those recorded in the

$1_{\text {Avery Dulles accurately remarks that in Infallible? Küng }}$ essentially "repudiates the very ideas of an infallible teaching office and of infallible dogmas" (Dulles, "Hans Küng's Infaliible? An Inquiry: A Symposium. I: The Theological Issues," America [124]:427).

2 John $J$. Hughes underlines this point, namely, that what Kung disputes is "the possibility of propositions guaranteed to be free of error in advance" (Hughes. "Infallitle? An Inquiry Considered," IS 32 [1971]:196).

${ }^{3}$ Infallible?, p. 81 .

${ }^{4}$ Ibid., p. 82.

5Ibid., p. 150 . 
Scriptures, are subject to constant revision due to their human formulation.

In other words, Küng contends that neither the ecclesiastical Magisteriur's spccial charism of truthi nor the inspiration of the Scriptures ${ }^{2}$ guarantee in advance the inerrancy of their

The Conference of German Bishops, in its "Declaration" of February 4, 1971, concerning Küng's Infallible?, includes among "some non-negotiable givens which no theology can deny if it is to remain Catholic" the point that dogmas do not draw their own proper normativeness "from the outcome of the theological debate, nor from the assent of a majority in the Church, but from the charism given to the Church to maintain the Word, once proclaimed in the force of its own truth, and to interpret it unerringly" (see Küng Dialogue, p. 40; emphasis supplied). The task of insuring that the church should remain in the truth of the gospel is entrusted in a special way to "the Magisterium," adds the Declaration (ibid.). Similarly, the Declaration of the CDF Mysterium ecclesiae dated June 24, 1973-which was issued as an indirect answer to küng's volume on infallibility--quotes Vatican II's Dogmatic Constitution on divine Revelation Def Verbum (article 8 ) which states that believers grow in the understanding of revealed truths, thanks in part to "the preaching of those who have received through episcopal succession the sure charism of truth" (see Küng Dialogue, p. 191). Hence in a letter to Kung dated March 30, 1974, the CDF insists: "You do know which are the presuppositions on which irfallibility rests. . . . The Catholic Church believes (see Vatican I) that, due to the assistance of the Holy Spirit, these presuppositions exclude the possibility of any error in a dogmatic definition (cf. Mysterium Ecclestae, 5)" (Küng Dialeque, p. 82).

${ }^{2}$ Roman Catholics have asserted clearly enough the divinely inspired nature of the Scriptures, meaning that they have God as their Author. The first explicit pronouncement on the matter by a general Council seems to have been Vatican I's "Dogmatic Constitution on the Catholic Faith," (April 24, 1870), chapcer 3: "The Church holds these books isf the 0ld and New Testament] as sacred and canonical, not because, having been put together by human industry alone, they were then approved by its authority; nor because they contain revelation without error; but because, having been written by the inspiration of the Holy Spirit, they have God as their author and, as such, they have been handed down to the Church itself" (see Denz, 1787). However, as Bruce Vawter points out, already the Council of Florence (1438-1445), where the term "Inspire" first entered into the conciliar language, reiterated the even previously devised "Deus auctor formula" (Vawter, Biblical Inspiration, p. 70). It is the teaching of this Council that the 
statements. His view is thus in direct contradiction with the teaching of the Roman Catholic Church, and, as far as the inspiration of the Scriptures is scricentid, with the beilief of conservative Protestants as well.

What is the criterion, in Kung's view, that distinguish between true and false propositions? If our theologian does not deny the possibility of expressing the faith of the church by means of true propositions--though in his eyes their truth cannot be regarded as guaranteed in advance by the assistance of the Holy Spirit--how can one know when a proposition expresses the truth? Which propositions are true? We are still dealing here with the criterion of Christian truth, the central question of our inquiry. While kung answers that the ultimace criterion of truth is the gospel of Jesus Christ and thus Jesus himself, we still need to find out what küng understands by "the gospel" and how one can know Jesus .

Apart from and in addition to objecting to the a priori infallibility of any proposition, küng holds also that propositions

church "professes one and the same God as the author of the old and New Testament, . . . since the saints of both Testaments have spoken with the inspiration of the same Holy Spirit" (see Denz, 706). So also the Council of Trent in its third session (February 4, 1546) affirmed that all the books of the OT and of the NT should be received and held in veneration "since God is the author of both" (see Denz, 783). After Vatican I, Pope Leo XIII's encyclical Providentissimus Deus (November 18, 1893) referred to the canonical books as having been written "at the dictation of the Holy Spirit; so far is it from the possibility of any error being present to divine inspiration, that it itself of itself not only excludes all error, but excludes it and rejects it as necessarily as it is necessary that God, the highest Truth, be the author of no error whatsoever" (see Denz, 1951). 
as such $^{1}$ can by no means be regarded as clear as mathematical truths. ${ }^{2}$ He has Ifttle room for equating knowledge with clear propositions, a view he describes ds naive and Cartesian, which concelves of knowledge as representation in one's mind of what reality actually is. ${ }^{3}$ This notion, he observes, assumes that the objects of knowledge are "so immovably static that the eye can simply seize on them, ${ }^{4}$ as it were.

Küng contends that, in seeing the sensible-spatial world is "simply extension. . . and thus identical with the object of geometry," Descartes extended, mistakenly, the mathematical ideal of knowledge to all sciences. Thus, "evidence--that is, clear and

$1_{\text {And, of course, theological propositions as well. }}$

Infallible?, pp. 161-62. The question remains, notes küng, whether mathematical truth provides a basis for the formation of the concept of truth as such. His answer is negative (see Does God Exist?, pp. 29-33).

${ }^{3} \mathrm{~A}$ theory whose "rationalistic origin" is found in Descartes, not in Thomas Aquinas, notes küng (Infallible?, Pp. 162. 164). Küng is not opposed to a "reflective striving for clarity, without which theology would be abandoned to confusion and destruction" (Infallible?, p. 168; emphasis his. Cf. Does God Exist?, pp. 22-26). On the contrary, among his "ten guiding principles for contemporary theology," our author affirms that "religion and rationality belong together!" (Küng, "New Consensus," p. 14, principle No. 5). Though there is a necessity for theology to aspire to clarity, theology "cannot expect to find the kind of clarity offered by mathematics and the cognate sciences" (Infallible?, p. 168). There remains a difference between theology "striving for the clarity and distinctness that is possible" in its propositions, and its claiming that its propositions "exhibit a definitive clarity and distinctness, that a quasi-mathematical evidence and certainty have been attained" (Does God Exist?, p. 31).

${ }^{4}$ Infallible?, p. 165. "In his demand for clarity and distinctness, Descartes started out from a naive, static conception of subject and object," observes küng (Does God Exist?, p. 30). 
distinct insight into the matter-was made the criterion of truth,

while truth iself was identified with certainty." I

Over against this idea küng affirms that "cognition never means that the object is known simply as it is." 2 In the process of knowledge some particular aspects of reality are stressed while others are left obscure. Cognition "includes and excludes, limits and deifmits." Thus, all knowledge is provisional and "in principle never complete."3 The epistemological criticism of Kant is evident here.

In brtet, Küng is opposed to what he regards as a static and rationalistic 4 view of truth. His point is that truth is dynamic 5 since both subject and object are always in motion in the frame of history, which itself is dynamic. Since rationalism depends on

I Ibid.

2 Does God Exist?, p. 30.

${ }^{3}$ Ibid. It is to the credit of Kant, and of Hegel after him, that the dynamism of the process of knowledge was understood, notes Küng (lbid.).

4 There is a difference, obsarves küng, as to whether philosophy and especially theology are committed "to the ciarity of rationality or to the pseudo clarity of rationalism" (Does God Exist?, p. 31).

5ruth is dynamic due to the dynamism of subject and object. writes Küng, following the Hegelian model of a dialectical knowledge of truth (see Infallible?. p. 166). The dynamism of the object means that what we know is itself in motion. The dynamism of the subject means that we are not static "like the camera on its tripod." Therefore, "perception and knowledge must be part of the whole movement and not dependent on apparently evident, fixed definitions and clear theses" (ibid.). 
fixed definitions and clear theses, it never can catch sight "of the living reality in its mobility, concreteness, and fullness." I

For Christian doctrine this dynamic notion of truth means that the church is always "on the road to truth." 2 The truth of the gospel of Jesus Christ, like the Spirit that the church has received, "is merely a pledge" which points into "that futuite wilich alone will bring the whole truth, the complete revelation, the kingdom of God." As the people of the old covenant in its journeying through the desert, so likewise the new people of God nay not settle down in "possession" of the truth. It must remain open to "the greater truth of the future." 3 It may not claim to know everything, shutting up the truth "in the golden cage of a closed system, tied to the present and soon to be tied to the past." 4 The Epistle to the Hebrews, states Küng, depicts the church as the pilgrim community of the faithful who possess the truth merely as a

Infallible?, p. 166; cf. Does God Exist?, pp. 29-33. See the denounciation of this position in Pope Pius XII's encyclical Humani generfs, above, p. 274 , n. 1.

${ }^{2}$ Infalible?, p. 178. In what follows, I am quoting from the section "The Church on the road to truth" (ibid., pp. 178-81).

${ }^{3}$ Küng, Does God Exist?, p. 31. Reacting to this view of Kung the CDF remarks in its Declaration Mysterium ecclesiae (June 24, 1973): "The faithful . . . must shun the opinion, first, that dogmatic formulas (or some category of them) cannot signify truth in a determinate way, but can only offer changeable approximations to it, which to a certain extent distort or alter it; secondly, that these formulas signify the truth only in an indeterminate way, this truth being like a goal that is constantly being sought by means of such approximations. Those who hold such an opinion do not avoid dogmatic relativism and they corrupt the concept of the Church's infallibility relative to the truth to be taught or held in a determinate way" (see Küng Dialoque, p. 194).

${ }^{4}$ Does God Exist?, p. 31. 
token of the great promise revealed in Christ. Also Paul stated--in Kung's opinton still more clearly than the author of Hebrews--"the provisional character" of all our knowledge by faith: "Now we are seeing a dim reflection in a mirror; but then we shall be seeing face to face" (see 1 Cor 13:9-10,12).1

In what has to do specificaily with the propositions of the Bible, Küng observes that even though they are not "a priori free from error," nevertheless, there are in fact in the Scriptures "true propositions attesting the gospel." 2 This, of course, leaves open the question as to which scriptural propositions belong to this category and on what basis.

At this point the bearing of Küng's dynamic understanding of truth upon his own model of orthodoxy-heresy seems obvious. For him, this dynamic view explains why truth cannot be petrified in fixed propositions. The living Christian message, Küng believes, cannot be absorbed neither into "infallible propositions of the ecclesiastical teaching office" nor into "infallible propositions of the Bible. ${ }^{3}$

\section{Truth lies in the total}

not in particulars

A consequence of his dynamic concept of truth is Küng's thesis that truth lies in the totality, "not in the particular

Isee Infallible?, Pp. 180-81.

2 Ibid., p. 220; emphasis in the original.

${ }^{3}$ Ibid., p. 210 . Cf. Christian, pp. 463-68; Maintained, pp. 44-57. 
steps, propositions, or elements of which it is made up." Hence one cannot actually "tell the truth by means of a single sentence in isolation. "1

As Hegel has shown, notes he, we need basically three sentences to give definiteness and precision to what we say: we need to affirm, then dialectically to deny, and eventually to surpass. ${ }^{2}$ In harmony with this pattern, the Swiss theologian suggests that our train of thought could be expressed in ordinary terms as follows: "That is how it is; no, it is not just like that; in fact there is more to it, this is what te is like." And so on. 3 Thus, along with Hegel's theory, "rigid conceptual thinking is turned into a living,

Isee Infallible?, p. 166. Cf. Does God Exist?, p. 31.

2 The dialectical thought of Hegel finds its central significance in the notion expressed by the German term "aufheber, " which basically means to lift up, and which in Hegel's usage says two dffferent, though in a sense identical things, namely, to cancel and to keep by transforming (see Kung, Menschwerdung, p. 245). The dialectical "Aufheben" means this: the truth which is affinued and regarded as absulute is denied and abandoned, given up ("faliengelassen"), yet in this giving up, it is at the same time resumed, taken up again ("wieder aufgenommen"), and elevared ("hinaufgehoben: tollere, conservare, elevare") into a superior unity (ibid., $p$. 250). Elsewhere Küng explains "what is the meaning ot this tern Aufheben, which has become so famous as a result of Hegel's use of it and which is scarcely translatable into other languages" (Does God Exist?, p. 146; emphasis his). The term has a triple meaning. Küng notes, and from it Hegel draws these conclusions: "The truth regarded as absolute must continually be discarded; but, in being discarded, it must at the same time be taken up afresh--as relative moment--and raised up into a higher unity" (ibid.; emphasis in the original). Küng comments that Hegel scarcely uses the words "thesis-antithesis-synthesis" so often ascribed to him. What he means is "the affirmation of a truth that turns into a denial and then again into a transcending of both affirmation and denial" (ibid.).

${ }^{3}$ See Infallible?, p. 166; and Does God Exist?, p. 31. 
mental dynanism." 1 Küng upholds, in essence, Hegel's concept that "Human consciousness. . . shares in the dynamism of the divine Absolute itself, which is. . . a subject and spirit moving vitally through all contradictions." 2

Küng is ther=fore able to provide a theoretical answer to the specific question why the errors of single pronouncements or actions of the church do not compromise fts total truth. Similarly, errors in single biblical statements do not affect the truth to which the Scriptures witness in their totality. Küng holds that neither the eruth of the church nor the truths of the Scriptures ${ }^{3}$ lie on single propositions or statements. Just as one can speak of the church's remaining in truth in spite of its individual errors, we may also speak of the truth of Scriptures "certainly in the sense of a testimony to Jesus Christ that, through all defects in detail. is sound and faithful as a whole." 4

\section{Iruth is historically relative}

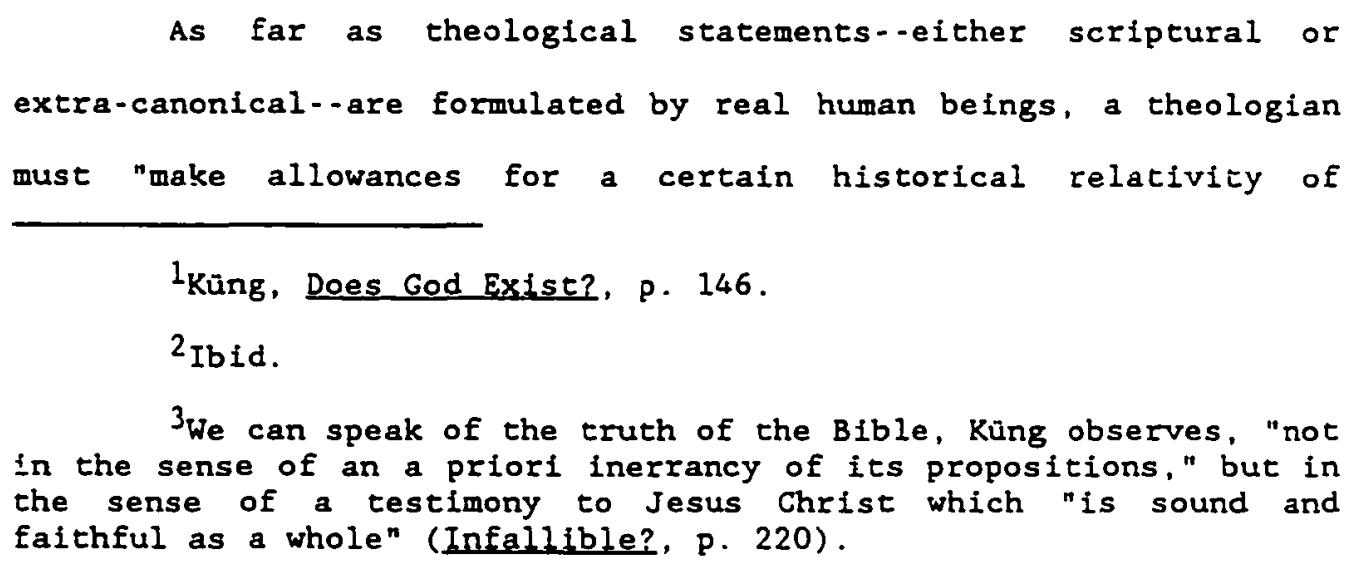

As far as theological statements-either scriptural or extra-canonical--are formulated by real human beings, a theologian must "make allowances for a certain historical relativity of

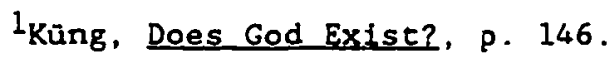

2 Ibid.

3we can speak of the truth of the Bible, Küng observes, "not In the sense of an a priori inerrancy of its propositions, "but in the sense of a testimony to Jesus Christ which "is sound and faithful as a wholen (Infallible?, p. 220).

4 Ibid. 
truth." 1 The historically conditioned nature of propositional truth is due in part to the fact that "words and sentences can completely change their meaning in a new situation." Language, Küng notes, is a "phenomenon of man's historicity." 2

In addition, our theologian points out that "a statement of Eruth polemically defined".-such as the classic example from the Catholic-Evangelical controversy, "the just man lives by faith".-is usually "o half-truth." By this he means that "what it states is correct; but what it does not state is also correct." 3 In Küng's view, what this specific statement affims is that faith is essential for one's life. What it does not state is also true, namely, that the just man is not exempt of doing works of love. However, since in a different historicsl context propositions and

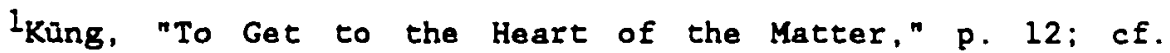
Rahner, "A Critique," p. 13. Gregory Baum, the Canadian theologian, holds that it is Rahner rather than kung who has reflected extensively on "the Inevitable historiclty of truth," though he grants that küng also recognizes truth's historicity (Baum, The Infallibility Debate, p. 27; see also p. 32, n. 16). According to Baum's analysis, Küng reveals his awareness of the historical relativity of truth in his concept that "every proposition can be true and false" (ibid., p. 32, n. 16; see also küng. Infallible?, p. 172). In my analysis of Kung's concept of truth, I separate the issues of "the inistoricity of truth" and "the dialectical nature of truth," since I regard them as two different things, as I attempt to show (see below, pp. 305ff). I study the referred Küngian statement under the latter ieading because the dialectical nature of a statement which can be "true and false" does not necessarily involve the historical or temporal dimension. Avery Dulles, for his part, even though critical of the way in which kung handles the problem of the church's abiding in the truth, acknowledges "the limits of infallibility and the historically conditioned character of all human apprehensions of the truth" (Dulles, "Hans Kung's Infall ble?," p. 428).

${ }^{2}$ Infalifible?, p. 160.

${ }^{3}$ Ibid., p. 171; emphasis his. See also p. 170. 
sentences can have "an unexpressed secondary meaning," the statement of this specific example might be understood nowadays as saying that "the just man lives by faith (and does no good works)." This is what Küng regards as "the shadow of error" that obscures the truth of the statement. 1 Hence the importance of recognizing the historical relativity of propositions of faith, namely, the fact that they address specific problems in concrete historical situations. Their wording cannot be regarded as expressing truths which exist out of the dimensions of time and space.

This leads us to review the way in which Küng refers to "defensive" propositions, ${ }^{2}$ i.e., theological propositions which in his opinion have to do with the problem of the church confronting heresy. The church, Küng observes, "is called upon constantly to proclaim the gospel afresh in continuously changing situations," 3 and at times it has to demarcate the gospel from what is unchristian by means of "defensive-defining propositions (definitions of faith

I Ib1d., p. 170; cf. Menschwerdung, pp. 612-13.

${ }^{2}$ Küng distingilishes at least three types of staiements of faith. "Defensive" propositions are one of them. The other two he calls, first, "abbreviating-recapitulating propositions (professions of faith or creeds)"; they are those formulas of faith which were not "statements of dogma in the modern sense," i.e." they were not meant to be "fixed, unsurpassable,. . . excluding new and different forms." Faith, küng holds, was not based on, but found expression in, such formulas. The second type of statements of faith consists in "tendentious-explicating propositions," namely, those statements which are not essential for the proclamation of the gospel, but that respond to "reasons of ecclesiastical or theological policy" (see Infallible?, Pp. 144-50; emphasis in the origina1).

$$
3 \text { Infalizible?, p. } 149 .
$$


or dogmas of faith)."1 He grants that the formulation of this kind of statements of faith, sometimes "in the negative," 2 is also present in the New Testament. Küng explains that, when in the course of time "the gospel had to be marked off more and more against heresies," occasions arose which required the formulation of propositions of faith. ${ }^{3}$ These were either to affirm a truth of the gospel or to reject heresies, and therefore acquired a binding force without meaning thereby that they were a priori free from error or closed to correction. ${ }^{4}$ These "defensive" propositions, remarks Küng, were a question of practical ruling. They were definitions which "may never be understood as a final judgment of damnation on men." They were formulated "on terminology conditioned by the situation. " 5

Besides, in what concerns the truths of the Scriptures, Küng's "historical" way of thinking ${ }^{6}$ is not unrelated to one

1 Ibid., pp. 146ff; emphasis in the orfginal.

2 According to kung, propositions of faith "in the negative" are particularly clear in 1 John $2: 22$ (the man who denies that Jesus is the Christ is the liar and the antichrist), and 1 John 4:2-3 (every spirit that does not acknowledge that Jesis Christ has come in the flesh is not from God). These are not positive propositions such as "Jesus is the Messiah" (see Infallible?, Pp. 146-47).

${ }^{3}$ Ibid., p. 147. This was a question of affirming or denying Jesus, notes king, "not of a faith in propositions, but of a proposition of faith" (ibid.; emphasis his).

${ }^{4}$ Kung's belief that formulations of faith are open to correction is consistent with his dynamic view of truth, in particular with the notion that there is always for the church a greater truth in the future (see above, PP. 297-98).

${ }^{5}$ See Infallible?, pp. 146-148.

6"Historicity" or historical consciousness, in Küng's 
particular dimension of his view on the nature of the church. Just as the church "is first and foremost a happening, a fact, an historical event"l (for the church "lives in this, not in another world"2), and thus in its "actual form" and "concrete reality"3 is made up of human beings ${ }^{4}$ with all their sin and historicity, so also the Scriptures were written by "real men in all their humanity, historicity and fallioility." 5 The humanity of the writers of the biblical documents mears that the latter were written in specific historical situations which affect the expression of Revelation. 6

understanding, regards reality as changeable and remporal, in contrast with the Platonic "immutability of essence" and "timeless. ness" of being (see Menschwerdung, p. 557). Cf. my discussion on the meaning of "historlcism" and on the historical way of thinking as a norm of orthodoxy above, pp. 102-08.

$1_{\text {Kung, The Church, p. } 23 .}$

2 Ibid., p. 21.

${ }^{3}$ Ibid. , p. 411.

4nour Church is very well aware that she is a Church of human belngs," remarked Küng five years before writing The Church (see May Believe, pp. 28-29; emphasis his). This means that "wrong decisions and wrong developments" are possible and are to be charged to "the human side of the Church" (ibid., p. 30). "It is human beings, not God, not the Lord, not the Spirit, who make up the Church" (The Church, p. 416).

The Church, p. 37. CE. Infallible?, p. 210: "Historicalcritical exegesis brought to light in an unexpected way the truly human character and historicity of the biblical authors." See also Christian, p. 465 .

${ }^{6}$ At the termination of the doctrinal proceedings of the CDF relative to Kung's volumes The Church and Infallible?, the Conference of German Bishops issued a Declaration (February 17 , 1975) in which it recognized both "the influence of historical clrcumstances upon linguistical formulations" and "the timeconditioned manner in which problems are raised," but pointed out that in spite of the former, "an absolutely valid and unalterable truth lives on in the dogma of the Church" (see Küng Dialogue, p. 
In küng's opinion te is this human historicity of the Scriptures

"which not only makes biblical eritisisim possible, but demands textual and literary critfism, historical and theological criticism." I

\section{Truth is dialecticial}

What we have seen thus far is closely related to the issue of the dialectical nature of truth. ${ }^{2}$ Küng's notion that the meaning of a statement cannot be understood apart from its historical context involves the recognition of a certain dialectical nature of propositionai truth, i.e., that the same specific proposition can.

97). Similarly, the CDF's Declaration Mysterium ecclesiae (June 24, 1973) had affirmed that "Difficulties arisa also from the historical condition that affects the expression of Revelation. With regard to this historical condition, it must first be observed that the meaning of the pronouncements of faith depend partly upon the expressive power of the language used at a certain point in time and in particular circumstances. Moreover, it sometimes happens that some dogmatic truth is first expressed incompletely (but not falsely), and at a later date, when considered in a broader context of faith or human knowledge, it receives a fuller and more perfect expression. . . Even though the truths which the Church intends tc teach through her dogmatic formulas are distinct from the changeable conceptions of a given epoch and can be expressed without them. nevertheless it can sometimes happen that these truths may be enunciated by the Sacred Magisterium in terms that bear traces of such conceptions" (see küng Dlalogue, pp. 193-94). Thus, though it implicitly grants Kung certain points, the CDF's declaration like that of the German Bishops' Conference underlines that. "As for the meaning of the dogmatic formulas, this remains ever true and constant in the Church, even when it is expressed with greater clarity or more developed" (ibid., p. 194; emphasis in the original).

Infalible?, p. 217.

2On the relationship between the historical and the dialectical natures of truth see above, p. 301, n. 1. 
at one and the same time, be true and false. 1 In fact, remarks Küng, "every proposition can be true and false," depending on its intended meaning and context. ${ }^{2}$

This view has been both resisted and misunderstood by some of Küng's critics. In his analysis of the Swiss theologian's volume Infallible?, George A. Lindbeck, for instance, is of the opinion that "the neuralgic point, the first premise, of his case against magisterial infallibility is highly questionable," namely, that a proposition can be true and false. This theory, notes Lindbeck, appears to deny the laws espoused by "the vast majority of both past and present logicians and philosophers" who say that a proposition must be either true or false, that "these two 'values' constitute a mutually exclusive and exhaustive dichotomy." Puzzled by Küng's position, Lindbeck observes that for küng "apparently all propositions are fallible." 3 Simllarly, Karl Rahner observes that in reading Küng's argumentation one often has the impression that for him "all particular propositions, though in different degrees, are always both true and false at the same time." 4 On the other hand, Gregory Baum notes that rather than undermining the logic of all human discourse, Küng's claim "is the simple acknowledgment that the

Infallible?, p. 170: Beyond the observation that propositions can be "true or false," Küng thinks that it must be added that "propositions can be true and false" (emphasis his).

2Ibid., p. 172; emphasis in the original.

${ }^{3}$ See Lindbeck, "Hans Küng's Infallible? An Inquiry: A Protestant Perspective," p. 431.

${ }^{4}$ Rahner, "A Critique of Küng," p. 17. 
meaning of a sentence cannot be determined apart from its context." 1 The same proposition "Jesus is man," Baum explains, can affirm the church's traditional teaching, while in a different context it can be a denial of Jesus' divinity. ${ }^{2}$

Perceiving that his view can be misunderstood, Küng explicitly states in Infallible?--though his clasification seems to be ignored by his critics--chat he does not mean that "all propositions are equally true and false." What he intends to say is that propositions, statements, even dogmatic pronouncements are "fundanentally ambiguous and consequently can be understood differently by different people. ${ }^{3}$ what he is saying, then, is that :t is not always easy to understand with absolute clarity the objective, the context, and the meaning intended by those who express themselves through human language. It is more difficult to discover how a proposition is intended than how it is said. ${ }^{4}$

In what sense, then, does küng affirm that a proposition can be true and false? As an illustration of his thesis he refers to the sixteenth-century controversy over justification. The Council of Trent, he notes, condemned a theory of justification "through faith alone" in the sense of "an empty, arrogant, obstinate belief that one is justified." It did not, however, define what can rightly be meant by "through faith alone,"--what the Reformers

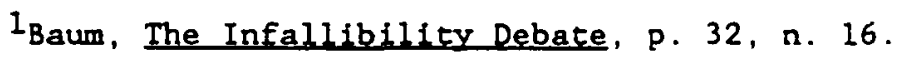

2 Ibid.

${ }^{3}$ Küng, Infallible?, p. 161.

${ }^{4}$ See ibid., p. 172.
} 
precisely meant, remarks Küng--namely, that true, sound faith places its trust solely in the Lord. Thus, what for one was the legitimate condemnation of the false notion of sola fide was for the other the wrong condemation of the true sola fide. 1

This shows that "there is no error without any core of truth."2 For this reason, Küng deems it important for the church to discern "the true concern behind the error, the truth within the error."3 In church history, he notes, it has occurred too often that "the true condemnation of the error" has seemed to the reproved party to be a condemnation of the truth. ${ }^{4}$ It is the task of Christian theologians, as well as the duty of the church as a whole. to constder serfously the truth in other's errors and the errors in one's own truth. 5

This "dlalectic of truth and error"6 must be taken

IIbid., pp. $171 \cdot 72$.

2Ibid., p. 170. For Küng's additional references to the difficulty "to distinguish absolutely between truth and error." errors in the church's doctrine, and "the element of truth in heresy" (see, for instance, May Believe, pp. 28-30; The Church, pp. 317-19, 329-32; Menschwerdung, p. 612).

3 Infal1ible?, p. 170 .

${ }^{4}$ Ibid., p. 171.

${ }^{5}$ See ibid., p. 172 ; cf. The Church, pp. 319-31, especially p. 330: "The Church, in addition to getting to know and understand heretics and their valid concerns, must weigh up these concerns carefully, and be prepared to take action on them to the extent that they are justified in the light of the Gospel of Jesus Christ."

${ }^{6}$ Infallible?, p. 172. Cf. Küng, Menschwerdung, p. 612. where the Swiss theologian notes that "One thing is true, error and truth are never distributed in clear-cut compartments; in the same way that there may be much error in orthodoxy, there may also be a great deal of truth in heresy." 
seriously, küng points out, in order to avoid falling into "dogmatism," which consists in "exaggerating and overvaluing the dogma, in isolating it and making it absolute." 1 As we saw earlier. in Küng's view dogmas have a functional character, ${ }^{2}$ being tied to the specific historical situation in which a particular heresy was being attacked.

The complext ty and unity of truch and reality

Thus far Küng's concept of truth has been shown to be both dynamic and complex. First, truth is more than merely correspondence between facts and the notions in the mind. It is essentially a quality of being (the "personal" dimension of truth). Second, in its propositional, "cognitive" dimension, Küng concelves truth as related both to human historicity and to the ambiguity inherent to all propositions, both in thought form and expressed through language. Thus, truth is defined as dynamic, historical, and dialectical. This means, respectively, that, first, there is always a more complete truth in the future. Second, truth, or rather the expression of $1 t$, must always be understood in context. Finally, there is no absolutely clear-cut separation between truth and error. All this means that truth is complex.

since truth is at bottom the conceptualization of reality. it would follow that küng sees reality as dynamic, historical, and

Infallible?, p. 172 .

2 See above, pp. 302-04. Küng believes that dogmas are "defensive propositions" which have the restricted function to define falth in particular doctrinal controversies. 
dialectical, too. In fact, in his discussion on the existence of God, he remarks that "the complex stratification of reality must be kept in mind Erom the outset," especially as opposed to "the ideology of rationalism"l which in the modern eza starts with Descartes' demand for clarity and distinctness ${ }^{2}$ and continues, for instance, with the Vienna Circle's representative Rudolf Carnap (1891-1970), who wanted to reduce reality to that which is empirical-rational, given in objective experience, and logically expressed in clear statements. ${ }^{3}$

In his demand for clarity and distinctness of knowledge, contends Küng, Descartes wrongly extended the mathematical ideal of knowledge to all sciences ${ }^{4}$ and started out from a naive, static, geometrical conception of all reality. 5 He demanded a radical methodical separation between the spatio-temporal-quantitative on the one hand, and the emotional-mental on the other. 6 This "Cartesian dualism," Küng poinis out, provides the starting point for both philosophical rationalism and philosophical empiricism,

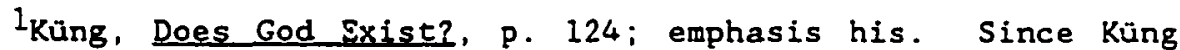
deals with this problem in a more detailed way in this volume, I rely mostly on it for my analysis. See also Küng, Christian, pp. 415 ff.

2Does God Exist?, p. 30. Cf. Infallible?, pp. 164-67.

${ }^{3}$ Does God Exist?, pp. $95-101$.

${ }^{4}$ Infalilible?, p. 165.

5Ibid. Cf. Does God Exist?, pp. 6-7, 30.

6 Does God Exist?, p. 27. 
311

materialism, and positivism. ${ }^{1}$ Thus, in Carnap's system the "requirement of scientific strictness" led to the banishment of all metaphysics, "since its theses cannot be rationally justified." 2 similarly, the phenomena of faith, for him, belong to the same "areas of Iife" in which intuition, poetry, and love must be grouped. They belong to "the nonrational areas" which are "altogether different from scierce" and cannot be called knowledge. These "nonrational areas, on the one hand, and science, on the other hand, can neither confirm nor disprove one another." 3

Arguing against this split concept of reality, ${ }^{4}$ which is

I Ibid., p. 29.

2Rudolf Carnap, Der lorische Aufbau der Welt (Berlin, 1928; reedited in Hamburg, 1961), p. xix; quoted in küng. Does God Exist?, p. 97. An Eng. trans. of Carnap's book exists: The Logical Structure of the World \& Pseudoproblems in Philosophy, trans. Rolf A. George (Berkeley and Los Angeles: University of California Press, 1967), P. xvi1.

At this juncture we may introduce Kung's position with respect to "metaphysics." He notes that the word itself has been "understood and misunderstood, used and misused," and so it is not important in itself. "What is important is to understand the thing properly," remarks he. Küng is not pursuing methaphysics if the latter is understood as human "projection" (Feuerbach), an ideological "superstructure" (Marx), an ideal "afterworld" (Nietzsche), an unreal "wishful world" (Freud), or even as "true reality" in the platonic sense of a realm set apart from present reality. On the contrary, küng understands "metaphysics" as that "meta-empirical" reality which does not lie "behind, beyond, above, outside this reality," but which, so to speak, "constitutes the inner aspect of present reality." It is in this sense that he pursues metaphysics or, as he says, "a word that may be preferred in order to avoid misunderstandings--ontology ('theory of being')" (see Küng, Does God Exist?, pp. 550-51; emphasis his).

${ }^{3}$ Carnap, The Logical Structure, p. 293. Cf. Küng, Does God Exist?, P. 98.

${ }^{4}$ Does God Exist?, pp. 26ff., and passim. Jürgen Moltmann refers to the cleavage in modern consciousness between faith and reason, or between theology and the natural sciences, as "the two- 
related to the thesis "that only propositions of mathematics and logic, together with those of the empirical sciences, can be meaningful." 1 küng affirms that not "ail dimeusiois of lhe human" can be grasped by the scientific method. 2 "Quantifying and formalizing are not adequate for the understanding of the world of the qualitative." notes he, nor for the apprehension of "such specifically human phenomena as smiling, humor, music, art, suffering, love, faith, in all their dimensions." All this means that reality is more than mathematics and physical phenomena. ${ }^{3}$

Genuine rationality, for küng, is not to be equated with "one-sidedness and one-dimensionality." This is so because of reality's multi-dimensional nature. It consists of various strata and planes, aspects and differentiations. ${ }^{4}$ He endorses philosopher Wilhelm Weischedel's assertion that "theie is not simply 'reality,' but very different planes of reality." 5 The complexity of reality

track thinking of the modern mind" which theology should try to overcome (see J. Moltmann, "Theology in the World of Modern Science," in J. Moltme.an, hope and Planning, trans. Margaret Clarkson (London: S.C.M. Press; New York: Harper \& Row, 1971], p. 204; see also pp. 201ff).

${ }^{1}$ Does God Exist?, p. 93.

2 Ibid., p. 119.

3Ibid., p. 120. Cf. Infallible?, pp. 165-67.

${ }^{4}$ Does God Exist?, pp. $124-25$.

$5_{W}$. Weischedel, "Was heisst Wirklichkeit?," in G. Ebeling, E. Jüngel, and G. Schunack, eds., Festschrift für Ernst Fuchs (Tübingen, 1973), pp. 343-44; quoted in Küng, Does God Exist?, p. 124. What is real, notes Weischedel, "can be encountered in wholly different ways and consequently can also bear a wholly different character. The reality of the atomic physicist is different from that of the Platonist, the reality of ordinary life is different 
means that "we cannot and may not make a particular aspect into absolute reality for then the other aspects will revolt." I

What is the relationship between this concept of reality and Küng's notion of Christian truth? Just as there are "different forms and strata of reality, so there are different forms of truth," notes he, ${ }^{2}$ and often "different strata of truth in one and the same reality." 3 We may therefore conclude that in the complexity of reality there is another argument in favor of Küng's thesis that Christian truth cannot be reduced to fixed propositional formulaElons which are frozen in time. It sannos be exhausted by human discourse, and it does not simply correspond to "facticity"4 or

from that of religious experience. Considered in its content, reality is fissured: it is differentiated on each occasion according to the aspect that comes into view" (ibid.).

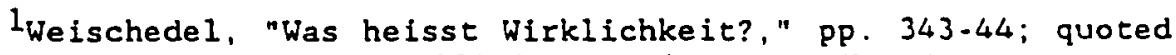
in Küng, Does God Exist?, pp. 124-25. To be sure, Küng's argumentation along these lines is aimed at disqualifying the claim of the positivists that God cannot bo krnw becalise the is not empirically verifiable and that all God-language is therefore meaningless.

${ }^{2}$ Christian, p. 415; emphasis Küng's.

${ }^{3}$ Ibid. This notion allows küng to justify the idea that beyond the interest of the historical-critical approach, which wants to test the historicity of the biblical statements ard of the events reported through them, our interest should be in the message which the biblical stories contain. "The Bible is interested primarily not in historical truth, but in truth relevant for our well-being, for our salvation, in the 'truth of salvation'" (Christian, p. 416). For this reason, Küng thinks that "the historian's question 'what actually happened?" is out of place" (ibid., p. 415). The differentiation of planes and strata of truth and reality allows Küng to claim that a story which is "historically true" may not affect us deeply, whereas an "invented story" like that of "the good Samaritan" may contain "more truth" since it "stirs us immediately." It contains a more "relevant ('existential') truth for me" (ibid.).

${ }^{4}$ Christian, Pp. 415-16. 
314

historical truth. This view of reality is also consistent with Küng's twofold notion that truth (including Christian truth) lies in the totality more than in particulars, and that our statements of truth are always provisional, incomplete, and thus open to reformulation and correction.

yosaver, for all its complexity and multiple dimensionality, Kūng remarks, "we may not overlook the unity in the various dimensions" of reality. 1 over against the two-floor theory, he holds that reality is "one." In fact, against the Thomist and Cartesian dualism criticized earlier, ${ }^{2}$ he contends that "the unity and truth of reality must once more be brought up for discussion."3 He supports Jürgen Molemann's assertion that even though Kant was correct when he warned that "a religion which, without hesitation, declares war on reason, will not, in the long run, be able to hold out against it." it also became evident that "even reason, in its enlightening victory over what it called faith, could not hold out alone, but developed highly unreasonable forms of naive credibility." 4 Küng and Moltmann agree that the $\varepsilon=\pi t$ inat "the tzuth is always one and must therefore be the truth of the whole" should move us to stress "the theological unity of reality" over against the

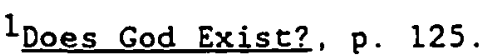

2 see ibid., pp. $3-41$ passim.

${ }^{3}$ Ibid., p. 125; emphasis in the original.

4 Moltmann, "Theology in the World of Modern Science," p. 207; quoted in Küng, Does God Exist?, p. 125. 
reductionisic, "naive positivism of science" with its one-sided approach to reality. 1

This "complexity and unity" of reality held by küng is reminiscent of his approach to the canon of the Scriptures, which he also regards as presenting a diversity of testimonies to the gospel which must nevertheless be understood as a whole. Likewise, his critique of the one-side:-.tess aru one-dimensionality of the positivist approach to truth and reality has striking correspondence with his concept of heresy as a one-sided, un-catholic, and selective treatment of the truths of revelation.

\section{Part Two: On Christian Trueh in a New Paradigm}

Since I have observed that the problematic of orthodoxy and heresy has to do in essence with the definition of religious truth and error, ${ }^{2}$ Küng's model of orthodoxy-haresy is better undetstood if we are able to grasp his concept of truth as comprehensively as possible. The historical, dynamic, dialectical, and, therefore, complex nature of truth which küng adrocates implies that both reality itself and our perception and understanding of it are always in flux. Change is therefore of the essence of his understanding of truth and reality. However, Küng's clinging to the normativity of the gospel of Jesus Christ for all that is Christian involves the advocacy of something which, being the essence of the Christian

lMoltmann, "Theology in the World of Modern Science," pp. 203, 207, 208. Cf. Küng, Does God Exist?, pp. 124-25.

${ }^{2}$ See above, "Introduction." 
religion, persists through all changes. We are here confronted with the continuity-and-change-in-theology phenomenon. In order to examine Küng's position on this issue, there is need to explore his "paradigm-change" theory. I I shall do so, in part 2 of this chapter, following two steps in compliance with the chronological sequence of Küng's own writing on the subject. ${ }^{2}$ The first step deals with the issue of "Paradigmenwechsel" in the context of the Swiss theologian's concept of God. The second step describes and analyzes his paradigm-change theory proper.

Two more reasons compel me to deal with Küng's doctrine of God in this context. For one thing, the historical and dynamic nature of truth which küng advocates is expected to affect his doctrine of God. One could say that his notion of the historicity and dynamic nature of God determines his concept of truth. Since God constitutes the ultimate reality, and his Being the ground of all being. Küng's understanding of the nature of God is in intimate relation with his concept of truth. In fact, he himself remarks that the questions of the unity of truth and the unity of reality "are obviously connected with the question of God." 3

\footnotetext{
$l_{\text {For a description of both the notion of "paradigm" as }}$ proposed by Küng and his "Paradigmenwechsel" (paradigm-change) theory, see below, pp. $339 \mathrm{ff}$.

${ }^{2}$ Before writing extensively about the change of paradigms in the history of theology and the church during the eighties, Kung briefly addressed the issue in his volume Does God Exist?, pp. 10625, 181-88 (Existiert Gott? was published in 1978). For references to Küng's more recent writings on Paradigmenwechsel, see below, pp. $340-42$.
}

${ }^{3}$ Küng, Does God Exist?, p. 125. 
Second, it is Küng's conviction that we are "in absolute need of a new, a modern understanding of God."l Since a new worldpicture has replaced the medieval, antiquated one, the antiquated image of God which belongs to it should also be changed. 2 In this way, in Küng's plea for a new concept of God, we have a cest case for his paradigm-change theory. Being related to both the historical concept of truth-and-reality and Paradigmenwechsel theory, the doctrine of God may be regarded as the pivotal point in dealing with Küng's modern interpretative criterion of orthodoxy.

\section{Truth, God, and Revelation}

In addition to what has just been expounded, I must point uui ihat my interast in analyzing Küng's view on the nature of God is not related merely to the issues of truth as such and the changes of paradigms. It has also to do with the subject of divine revelation, which in turn is related in a special way with the nature of the canonical Scriptures. This study of this issue should therefore shed some light on the question of Küng's use of the historical-critical methods in his reading of the Canon.

As for Küng's teaching regarding the nature of God, I pay special attention to two of his volumes in which this topic is

I Ibid. He thinks that "In view of the one world and of the one humanity, a new, meaningful, critical-dialogic collaboration" must be sought between theology and "both modern philosophy and modern thought as a whole" (ibid., $p$ 181; emphasis in the original). This means that "a radical course correction on the part of the Church and theology" are inevitable, a change which must include our understanding of God.

2 "Has not the change from the older paradigm already set in?" asks Küng (Does God Exist?, p. 181). 
addressed more extensively. These are Menschwerdung Gotes and Does God Exist?. For the purpose of this dissertation, let us briefly describe the main traits of his thought on this point.

\section{The modern understanding of God}

Küng's pastoral concern for presenting the gospel to modern mentality in a relevant, meaningful way compels him to express his conviction that "modern man need no longer imagine or think God in the same way as ancient or medieval man." I A "methodical rethinking" is necessary with reference to "the antiquated image of God" which is linked with the antiquated "Greek, medieval or earlymodern" world-picture. 2 The question as to "does God exist?" must be correctly stated, notes Küng; that is, "it must be stated for modern man.. . in a form that can be understood today, adapted to present-day modes of thinking." 3

In discussing old images of God, our theologian distinguishes the biblical God, "the God of Abraham, Isaac and Jacob," and a philosophical God, the "abstract God of ph:losophers and scholars." 4 Kung claims that Pascal is the chief historic representative of those who appeal to the biblical God, while he sees Descartes as the typical proponent of an abstract, philosophical God. These two understandings of God manifest the cleavage between faith and reason

IDoes God Exist?, p. 182.

2Ibid., pp. 181-82; emphasis in the original. Cf. Menschwerdung, pp. $524 \mathrm{ff}$.

${ }^{3}$ Does God Exist?, p. 181.

${ }^{4}$ Ibid., p. 182. 
which küng criticized in connection with his concept of the unity of reality and truth. Harmonizing these two positions is Hegel, I who, "contrary to both Descartes and Pascal" sought a reconciliation of

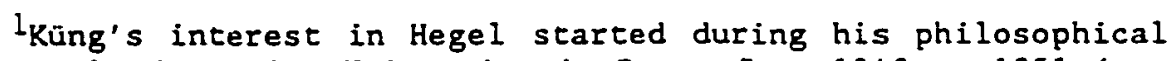
studies at the Gregorian University in Rome. From 1948 to 1951 (see Haring and Kuschel, "Interview," p. 155). It was Father Wilhelm Klein, Küng says, who focused at that time his attention both on Hegel and Barth (ibid., p. 135; cf. Kiwiet, Hans Küng, p. 18). His work on Hegel's Christology had originally been intended for a doctorate in philosophy at the Sorbonne. It was published ten years later, in 1970, after having undergone four revisions ("Interview," p. 154). The book bears the title Menschwerdung Gotces: Eine Einfurung in Hegels theologisches Denken als Prolegomena zu einer kunftigen Christologie.

In his constant interest for renewing the presentation of the Gospel for the present day, Küng considered Hegelian speculation as helpful ("Interview," p. 156). His specific purpose in studying Hegel was to provide a philosophical support for the "high" Christology which he, Kung, advocated in his early years. Häring and Kuschel remark that this "high" Christology, or Christology "from above," was presupposed in Küng's book Justification, and that the shift to a Christology from below occurred later in Tübingen when he began to work once more on the draft of Menschwerdung (see "Interview," pp. 155-56). Kung accepted the chair of Dogmatic and Ecumenic Theology at Tübingen in 1963. The first draft of Menschwerdung had been completed in 1960 (see Haring and Kuschel, W\&W, PP. 18, 16). Küng states that at Tübingen the influence of Ernst Kasemann, one of Bultmann's pupils, led him to accept the historical-critical principles of exegesis and to conciuce that it was very difficult to maintain the speculative Hagetian understanding of God and Christology ("Interview," p. 156). I have commented earlier on the fact that during the ten years that separate kung's first investigation on Hegel's philosophy and theology from the date of the publication of Menschwerdung an important shift took place in his theological views (see above, pp. 135-43). In the last section of the last chapter of Menschwerdung this change is evident, particulariy when Küng moves from a Chriscology "from above" on Hegel's lines to a Christology "from below." This shift moves Joseph fitzer to evaluate Küng's volume as being "nut one book at all, but at least two books, and maybe three. It does not hang together" (Joseph Fitzer, "Hegel and the Incarnation: A Response to Hans Küng," JRe1 52 [1972]:241. Fitzer observes that "The cleavage between what one feels was written nine years ago and what was written only recently occurs at the sixth and last section of chapter 7" (ibid.). At the beginning of chapter 8 Küng does attempt, without success, to gather the book together, notes Fitzer (ibid.). 
"a philosophical and a biblical God." Even though in this respect Küng agrees with Hegel in principle, he also questions the German philrsopher's attempt at reconciliation by "transforming faith into knowledge" and "the biblical God into a philosophical Absolute."2 Still, though he raises other objections to Hegel's theology, 3 especially in what has to do with his identification between the

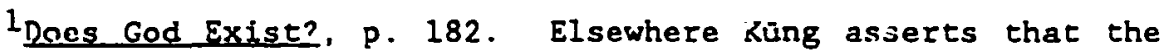
"post-Hegelian" concept of God is neither "naively anthropomorphic" nor simflar to the God of the Deism of the Enlightenment, the "God of modern philosophers." The post-Hegelian is a living God, is God in the world: "transcendence in the immanence," "otherworldliness in thisworldliness [Jenseitigkeit in der Diesseitigkeit]." See Menschwerdung, p. 296; emphasis is Küng's.

2 Does God Exist?, p. 182.

${ }^{3}$ For one thing, Küng questions the idealist monism of Hegel's philosophical system (see Menschwerdung, pp. 503-22, 553, 557). He is also uneasy about what seems to be Hegel's denial of God's freedom and power of decision as depicted in the Bible. Hegel's God is Creator and Revealer by a necessity of His nature and essence; He is gracious toward man because He could not have decided otherwise (see lbid., pp. 345-56, especially pp. 353-54. See also Does God Exist?, Pp. 166-69). Besides, kang wonders whether in Hegel's system "metaphysics is Christianized or the Christian message metaphysicized." Hegelian Christianity, Küng remarks, is "impenetrably amblquous" (Menschwerdung, pp. 495-96; emphas is is Küng's). It is the opinion of Joseph Fitzer that in Küng's Menschwerduns "hegel's views are compared with the New Testament faith witness and found wanting" (Joseph Iltzer, "Hegel and the Incarnation: A Response to Hans Kung," JRel 52 [1972]:241). Fitzer observes that "What Kung does is (a) state Hegel's views, (b) reject them, and then (c) state that contemporary theologians are concerned with essentialiy the same problems as Hegel was" (ibid., p. 242). Nobody, however, should conclude that küng mounts a frontal attack against Hegel's philosophy. As the discussion below shows, the Swiss theologian evaluates in a very positive manner Hegel's contribution to a modern understanding of the Christian message. Though he does not follow the German philosopher through all lines--and though he has abandoned the Hegellan speculation which he formerly endorsed in connection with a "high" Christology and his understanding of God (see Haring and Kuschel, "Interview," p. 156)--Küng has generally retained the Hegelian method of double negation and sublation as, for instance, in his volume Christian (cf. Matthew $L$. Lamb's "Review of On Being a Christian," RelsRev 4 [1978]:93). 
divine and the world, 1 Küng thinks that "the secularity and historicity of God must be freshly considered" today in the light of Hegel's writings. ${ }^{2}$

Hegel's conception of God is better appreciated when contrasted with the static notion of God of early Christianity, which adopted some concepts held by classical Greek metaphysics. ${ }^{3}$ According to küng, Hegel's main theological interest is "the dynamic unity in the living divinity. ${ }^{4}$ The living God is for him the one "who moves, who changes, who goes through history. The one who does not stay rigidly what he is, but who becomes what he is." 5

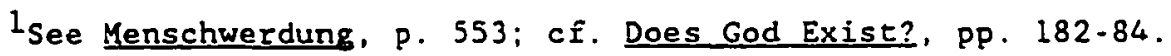

2 Does God Exist?, pp. 183-84. For this matter, Küng also finds helpful. though not without objecting to some aspects of their views, the insights provided by Teilhard de Chardin and Whitehead (see ibid., pp. 171-76: "The God of Evolution: Pierre Teilhard de Chardin;" and pp. 176-81: "God in Process: Alfred North Whitehead").

3One of the main theses of Küng's Meri=hiwerdung is that "a new appreciation of Hegel may liberate theology from some of the static categories to which it has become bound," notes Winfried Corduan i"Hegelian Themes in Contemporary Theology," JEvTS 22 [1979]:354).

${ }^{4}$ Küng, Menschwerdung, p. 526.

SIbid.; emphasis his. Elsewhere Küng explained that one of the main motives for him to study Hegel's theology was to attain with the help of this philosopher's diaiectical thought "a more dynamic understanding of God" and "a more profoundly based Christology that as far as possible avoided the weaknesses of the static, classical Christology as it has been handed down to us from the time of the great Christological councils of the first millennium" (Haring and Kuschel, "Interview," p. 155). In particular, Küng appreciated Hegel's understanding of Christology "as God becoming man" (ibid.). Though he has forsaken the Christological approach "from above" (see above, p. 320, n. 3) our author still wants to see, with Hegel, the reality of God's involvement with uan in such a way that He is not deprived of the possibility of suffering, of identifying Himself with the world, and of acting in human history in Scriptural fashion (see Küng. 
In addition to Küng's retaining the hegelian method of double negation and sublation as a characteristic of his theological reasoning, this dynamic and historical concept of God (and reality) must be counted among the major influences of Hegel's ontology upon Küng's theology. In Küng's opinion. Hegel's dynamic and historical concept of God overcomes two fundamental problems posed from the beginnings of western philosophy, i.e.. those concerning the antitiseses of "being and becoming" (Sein und Werden) and "unity and diversity" (Einheit und Vielfalt). ${ }^{1}$

The central issue regarding the philosophical question of being-and-becoming is the antithesis of immutability-changeability, which bears upon the historicist concept of God held by Küng over against the static, immutable God of Hellenistic theology. On the other hand, the central issue regarding the philosophical question of unity-and-plurality is the separation of reality in two floors, as it were, which affected the classical Greek understanding of the relation of God with the physical world where man lives.

The adoption by küng of the modern interpretative criterion expressed in the historical way of thinking as a norm of truth is clearly perceived in his discussion on the modern understanding of God contrasted with the antiquated Hellenistic conceptuality.

Menschwerdung, Pp. 522-57; cf. Does God Exist?, PP. 144-54, 181-88; see Corduan, "Hegelian Themes," p. 355).

$1_{\text {Menschwerdung, p. } 526 .}$ 
The Hellenistic and the modern

historicist views compared

The comparison of the Hellenistic conception of the rigid transcendence of an immutable God with the modern historicist notion must begin with a study, however brlef, of the essentials of classical Greek philosophy. Küng calls our attention to the preSocratic attempts at explaining the process of change in things, of their disturbing becoming and perishing. In this context, he contrasts the theories of Heraclitus of Ephesus and Parmenides of Elea. Heraclitus explained change by means of the theory that all things are in flux. 1 He was the first in developing a "radical philosophy of becoming, 2 remarks küng. On the other hand, Parmentdes, ${ }^{3}$ a younger contemporary of the Ephesian philosopher, was the first who "dared to explain all becoming as mere appearance" and to attribute to the "One Being" not only "underived being" (Ungewordensein) and "unchangeableness" (Unverănderlichkeit) but also "immoiiifty" (Unbeweglichkeit) and a "total immutability" (Unverănderlichkeit in absoluter starxheit). Parmenides' Being has neither

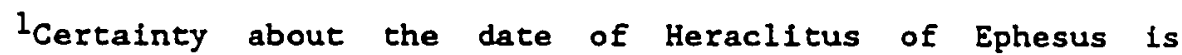
difficult. He may have been forty years old about 500 B.C. His philoshophical work is thought to have been completed by 480 (see W. K. C. Guthrie, A History of Greek Philosophy, 6 vols. [Cambridge: at the University Press, 1962], 1:408. He expressed his concept of constant change by saying that "you cannot step twice into the same river." This concept of flux, he thought, must apply not only to rivers but to all things (see Samuel Enoch Stumpf, Socrates to Sartig: A History of Philosophy (New York: McGraw-Hill Book Company, 1982], P. 12).

2 Menschwerdung, p. 527.

3Based on Plato's dialogue Parmenides, Guthrie assumes that Parmenides was born about 515-510 B.C. (Guthrie, A History of Greek Philosophy, 2:1). 
past nor future. For him, "the being is, and it cannot not be."l The influence of Parmenides is such, Küng observes, that after him and until the time of Spinoza (1632-1677), philosophy has to be understood mostly as Eullowing Parmenidan lines in "an open reaction against Heraclitus." 2 In this way, the ontology of Plato, for instance, with its dualist theory of the ideas, ${ }^{3}$ as well as the Aristotelian theory of "energy" which tends to explain movement in relation to the unmovable nous, and the dynamic emanation-philosophy of Plotinus 4 with its concept of the lifeless "original One" are all grounded in Parmenides. Rooted in all these is "the scholastic metaphysics of the Mlddle Ages," Küng observes. 5

The three chief representatives of classical Greek philosophy--that is to say Plato, Arfstotle, and Plotinus-."had an

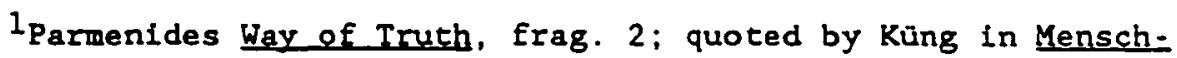
werdung Gottes, p. 527. For an Eng. trans. of Parmenides' work, see Francis MacDonald Cornford, Plato and Parmenides: Parmenides' "Way of Truth" and Plato's "Pamenides" translated with an Introduction and a Running Commentary (London: Routledge \& Kegan Paul, 1939, 1964), P. 30 .

2 Menschwerdung, p. 527.

${ }^{3}$ Elsewhere Kung observes: "It was Plato who mediared between Heraclitus' philosophy of becoming and Parmenides' philosophy of being by introducing into the history of Western thought that momentous dualistic division of reality that has confronted us so often: the partition between the untrue, bad, disintegrated, sensible world of becoming (in Heraclitus' sense) and the true, one, mental world of being (in Parmenides' sense), in a word, the metaphys Ical" (Does God Exist?, p. 184).

${ }^{4}$ Usually considered the founder of neo-Platonism, Plotinus lived between 205 and 270 A.D.

${ }^{5}$ Does God Exist?. p. 184. 
Eleatic ${ }^{1}$ conception if not of being, at least of the divine." 2 The eternity (in the sense of "unoriginated being"), immutability and absolute immobility which Parmenides attributed to being as such, was attributed by the former three philosophers to the supreme principle of all being. In this sense, notes Küng, "the Platonic idea of the Good, the Aristotelic unmovable Mover, and the One of Plotinus correspond to the Being of Parmenides." 3

As for Plato's ontology. what is its significance, according to Küng, for the understanding of God? The clear division made by Plato "between the divine world of ideas, with the supreme idea of the Good, and the phenomenal world of the senses, which consists of evil matter, "4 meant an unsurmountable separation ( $X^{\text {wplopós }}$ ) between the mutability of this "spatial and temporal world" and the eternal immutability of that other realm which is out of space and time, and above the firmament." 5 In his attempt at overcoming the naive, anthropcmorphic understanding of God, ${ }^{6}$ Plato stressed "the fundamental difference between being and becoming. " 7

1 The name traditionally given to the philosophisal school founded by Parmenides in Elea.

2 Menschwerdung, p. 529.

${ }^{3}$ Ibid.

${ }^{4}$ Does God Exist?, p. 184. Cf. Menschwerdung, p. 528.

5 Menschwerdung, p. 528 .

${ }^{6}$ Sharply criticizing the capricious and cemperamental gods of Homer, Plato saw the divine primordial principle as absolutely unmoving and unchanging, explains küng (Does God Exist?, p. 186).

${ }^{7}$ Ibid. 
What are, for Küng, the implications of Aristotle's philosophy for an understanding of God? Even though he succeeded in "bringing down from heaven the supramundane divine ideas of Plato and relocating them in the things of this world,"1 Aristotle made the divine mind "so rigidly unchangeable and so radically exclusive of any movement" 2 that the distance to the First Principle or prime Mover which is unmovable and immobile in himself remains difficult to bridge. This divine nous, being pure actuality, is petrified in his immobility in such a way that all that he can know is nothing

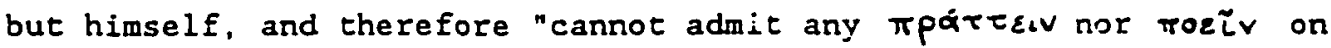
behalf of anything else." 3 Any movement would mean change, and any change would imply "a not-yet, an unactualized potentiality, a defect. . . Becoming is impertection. "4

What about the neo-Platonist Plotinus? Küng points out that even though he largely overcame the Platonic rigidity by a system of strata of being which emanate out of one another, for Plotinus, too, the supreme principle of all being, the divine One, remains in an "absolutely rigid unchangeability" so that even life has to be excluded from it. 5

The classic Greek notion of the immobility and unchangeability of God deeply affected Christian theology, Küng reminds us.

IIbid., p. 184; ef. Menschwerdung, p. 530.

2 Does God Exist?, p. 186.

3 Menschwerdung, p. 529.

${ }^{4}$ Does God Exist?, p. 186.

${ }^{5}$ See Menschwerdung, p. 529; and Does God Exist?, Pp. 186-87. 
One must keep in mind this Platonic and Aristotelian concept of God in order to truly appreciate the monumental significance of the Christian proclamation of a God who acts in history--a God whe creates, intervenes, knows, and loves the world. The mere notion of such a God was "in Elagrant contradiction with the Greek conception of the rigid transcendence of an immutable God."l But in the difficult task of introducing the Judeo-Christian faith in the Hellenistic world--a faith which had at its very center the belief in the divine Logos who became man!--it was inevitable, 2 in Küng's opinion, that both the New Testament and the apostolic fathers made connections with the philosophical thought concerning God. This applied specifically to "the negative predicates" about Him: "Invisible, imperishable, uncorruptible, not begotten, immutable, non-temporal, impassible." 3

Küng thinks it is necessary to acknowledge, however, that nat least in principle Greek metaphysics was subordinated to Christian faith." 4 In the $\mathrm{NI}$ in particular, redemption is expressed

\section{Ibid.}

${ }^{2}$ Küng writes that in describing the tranformation in primitive Christian theology, which to some extent constituted the hellenization of the Christian message, he is not willing to insinuate that it would have been possible to dispense with philosophical concepts compietely, or even that they should have been avoided. He is merely pointing to a historical fact (see Menschwerdung, pp. 535-36).

3 Ibid., p. 532 .

4Ibid., p. 533. He quotes Wolfhart Pannenberg's observation, against Ritschl and Harnack, that ancient Christian theology did not abandon the Christian concept of God to replace it by a "defst" one in its use of categories belonging to the Greek concept of God (see Wolfhart Pannenberg, "Die Aufnahme des philosophischen 
in historical categories, "not in purely ontological ones (nature, person, hypostasis, etc.)."1 Indeed, that idea which we today call "historicity" (Geschichtlichkeit), and which in modern times found expression in the philosophical system of Hegel, is present already in the Scriptures of the $01 d$ and New Testaments, remarks Küng. ${ }^{2}$ There is a striking contrast between the God described in the OT and NT, on the one hand, and the God of the classical Greek pililosophy, on the other. ${ }^{3}$ Hence, in his critique of the hellenization of early Christian theology, Küng contrasts the immutable God of the Christlan apologists ${ }^{4}$ with "the living God of the Bible;"5 the way in which the unity of jesus with God was explained on the basis of the Greek concept of God, with the more functional way in which that unity is "emphasized in the New Testament:"6 the testimony of the Gospels concerning Christ's suffering, with the way in which his suffering was sometimes questioned in later theology, 7 and so on. Küng is thus suggesting that, when compared with the ancient

Gottesbegriffs als dogmatiscines Probleme in der frühchristlichen Theologle," ZKG 70 [1959]:16-38. See also idem, Grundfragen systematischer Theologie: Gesammelte Aufsatze (Gottingen, 19671).

1Menschwerdung, p. 533 .

2 Ibid., p. 557.

${ }^{3}$ Ibid., pP. $534-36$.

${ }^{4}$ Aristides, Justin, Athenagoras, Theophilos, and Tatian took the concept of immutability from Greek mataphysics, notes küng (ibid., p. 534).

5Ibid., p. 535. See also p. 536.

6 Ibid., p. 536.

7 Ibid. , p. 538 . 
church's Hellenistic model of theology, the theology of the Scriptures appears as more correct since this is where "God's historicity"l is described.

In spite of the efforts of the early fathers to use the philosophical concepts of God critically ${ }^{2}$ in their proclamation of the gospel to a Hellenistic world, "the apologists of the second century" were the first to receive methodically and apply consequently the philosophical idea of God. ${ }^{3}$ As a result, "the eternity of God." for instance, "was understood too much under the sign of Placo's timelessness, and too little as the effective living coexistence in all time." 4 Likewise in their dialogues with the pagans, especially when attacking polytheism and pagan cusmologies, the apologists took over the immutability of God in the sense of Aristotle's theology. They "hardly appealed to the Scriptures; and if these ones were consulted at all, their voice was heard with Hellenistic ears." 5

I Ibid., p. 556; emphasis in the original.

$2 n$ Christian theology corrected the Greek idea of unchangeability up to a point," remarks king. "For the classical theology of the Fathers of the Church and the great patristic age, God is always the living God. This claim, however, is often implicitly contradicted as a result of the way in which this theology remains tied to the Greek idea of unchangeability: here, too, a real change would seem to imply a defect in God" (Does God Exist?, p. 187).

3 Menschwerdung, p. 532 .

${ }^{4}$ Ibid., p. 534. Küng refers likewise to God's omnipresence, goodness, justice, immutability, and incomprehensiveness, contrasting the historical-secular notion implicit in the Scriptures with the static-absolutely transcendent concept of God characteristic of classical Greek philosophy (see ibid., pp. 534ff).

SIbid., p. 535. 
Küng's advocacy of the historicist concept of God as over against the Hellenistic one is sumarized in the following points: ${ }^{1}$ (1) "God is not the absolutely immovable and unchangeable, who knows only himself." He cannot either be found in "an unchanging, eternal 'metaphysical' world set apart from the changing, temporal 'physical' world." There is no room today for a Greek-metaphysical concept of God, therefore "there is no nonhistoricity of God." God is not timeless, static being itself, "excluding any coming to be and any genuine future." Nor is the to be found "in a suprahistorical sphere, from which he would intervene miraculously in the history of the world of man." It is no longer possible to hold a "medieval-metaphysical concept of God," hence "chere is no suprahistoricity of God." (3) On the contrary, "God is the living God, always the selfsame, dynamically actual and continually active in history." He is thus "the eternal, who founds, sustains and completes history." He is "the historical primal reason and primal meaning of the whole reality of world and man."

This is how Küng sees "a power of God over history immanent to history: a modern, dynamic understanding of God."2 His suggestion that the historicity of God is inherent in the biblical conceptuality ${ }^{3}$ implies that the modern historicist way of thinking is not foreign to the Canon. Indeed, he notes that the "biblical

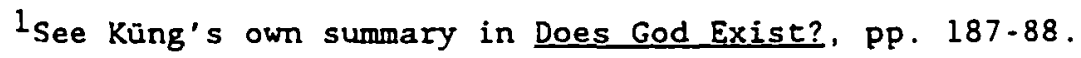

2 Ibid., p. 188 .

${ }^{3}$ Menschwerdung, p. 556 . 
messagen $^{1}$ of a God who is ailive and active in hiscory rather than persisting "unmoving and unchanging in an unhistorical or suprahistorical sphere" can be better understood in the light of today's historical thinking than "in the light of classical Greek or medieval metaphysics." 2

It must be underlined, however, that küng does not see the Ganon as the norm for an adequate understanding of lod in our tirse. He explicitly expresses his hope that Hegel will become the guarantee that today's understanding of God will not revert into "primitive anthropomorphic biblicism" or an "abstract Hellenism." 3 The two former conceptions of God's nature should rather be "sublated"4 ("aufhebt") in the best sense of Hegel's use of the word, remarks küng: to deny and to affirm at the same time, but in fact to affirm something superior to the two former premises ("negative, positive, supereminenter"). 5 The adoption by küug of Hegel's dialectical method of thinking is thus obvious.

'Does God Exist?, p. 188; emphasis is Küng's.

2 Ibid.

3 Menschwerdung, p. 556.

4"Sublation" and "to sublate" are the exact equivalents of the German terms "Aufhebung" and "aufheben," observes Edward Quinn (see translator's footnote in Küng, Does God Exist?, p. 140). Derived from the past participle of the Latin tollere (which means both to remove and to elevate), these English terms render quite closely the idea expressed by Hegel in his use of "aufheben," namely, "to cancel," "to preserve," "to elevate," and "to transfigure," all at once! (ibid.).

5 Menschwerdung, p. 556. 
As we have noticed, Küng points out that Plato, under the influence of both the Eleatic philosophy of being and the Pychagorean dualism, divided reality in two separate realms, a theory which was to have "very grave consequences." l Christian theology corrected this dualism in several ways, he notes. Thus, in the classical theology of the fathers of the church and the patristic age in general, "God is immanent in the world by the very fact of being transcendent to it." 2 still, he points out, it is also true that Christian theology through its history has generally remained "tled to dualism in many ways: according to this theology also, a real relationship to the world would make God dependent on the world."3 Küng asserts that Descartes sharpened this dualism to the point that he prepared the way for "the Deisu of the Enlightenment, which, again, completely separated God and the world." 4

As far as Aristotle is concerned, Küng notes that even though he brought down from heaven "the supramundane divine ideas of Plato," Aristotle's God remained absolutely separated from the world. "Apart from the divine impulse to set the world in motion, 5

I Ibid., p. 528 .

2 Does God Exist?, p. 184.

${ }^{3}$ Ibid., pp. $184-85$.

${ }^{4}$ Ibid., p. 185 .

5In a volume which explains Aristotle's philosophy in a nonscholarly though accurate manner. Mortimer Adler notes that the Greek philosopher's "prime mover" is not the efficient but the final cause of the universe's movement. In other words, the prime mover causes motion "by being attractive rather than propulsive" (Mortimer $\mathrm{J}$. Adler, Aristotle for Everybody [New York: Macmillan Publishing Co., 1978], PP. 185-86). Cf. Küng, Menschwerdung, Pp. 530-31. 
God and the world live from eternity merely in juxtaposition." 1 Aristotle's God does not know the world, nor does he love it. Nor is there any "causal activity" of this God. "No Providence, no establishment of a moral order and no system of laws.. . might be traced back to him." 2 In Aristotle's view, any real relationship of God to the world would imply a potentia, a becoming, an increase in his knowledge, a moving to a place not before occupied by him: in one word, a defect of this divine Being who was conceived by hila, by definition and due to his absolute perfection, as not possibly lacking anything. ${ }^{3}$ This dualism, which according to Küng was sharpened by Descartes and stressed by the Deism of the Enlightenment, was eventually overcome by Hegel. Despite the reservations that Küng expresses in regard to Hegel's identification of God and the world, ${ }^{4}$ he firmly believes that modern theological thinking must not be allowed to fall behind the conclusions reached by the German philosopher. The secularity of God must be stressed over against the dualistic philosophy which advocates His absolute transcendence. Küng's understanding of God's secularity means basically that "God is not a supramundane being, above the clouds, in the physical heaven." This "naive, antropomorphic idea is obsolete."5 By this statement küng wants to underline that God is not "unrelated

IMenschwerdung, p. 530. Cf. Does God Exist?, p. 184.

2 Does God Exist?, p. 184. Cf. Menschwerdung, p. 531.

${ }^{3}$ See Menschwerdung, p. 531.

${ }^{4}$ See above, pp. 320-21.

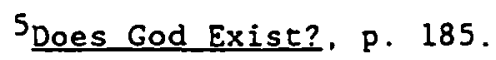


to man and the world in their historicity." 1 He is not "retired from the concrete life of the world and man." 2 He is not "in any mental or metaphysical sense 'outside' the world, existing. . . In an extramundane beyond." This "rationalistic-deistic idea" is also "obsolete." On the contrary, "God is in this world, and this world is in God." This does not mean, Küng clarifies, that God is finite. "He is in fact the infinite in the finite," He is "transcendence in inmanence." It is precisely as the absolute that God can enter into relationship with the world and man, a relationship not in the sense of weakness, of dependence, of relativity in the bad sense, but of strength, of unlimited freedom, of absolute sovereignty. God is therefore the absolute who includes and creates relativity, who, precisely as free, makes possible and actualizes relationship. ${ }^{3}$

Again, Küng affirms that in the light of this secularity of God, "the biblical message of a God who does not exist in isolation from the world but acts in the midst of the world"4 can be understood better than in the light of the metaphysical conceptuality of classical Greek philosophy or medieval theology.

Two final observations are necessary here. First, Küng's adoption of Hegel's dialectical pattern of reasoning is evident. 5

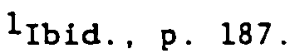

2 Ibid., p. 185.

${ }^{3}$ Ibid. , p. 185.

${ }^{4}$ Ibid., p. 186; emphasis is Küng's.

${ }^{5}$ It is particularly obvious in statements like this: "God as the absolute-relative, here-herediter, transcendent-immanent . . is the close-distant, secular-nonsecular God" (ibid., pp. 185-86). 
Next, in harmony with his dialectical way of thinking, Küng declares that it should be clear enough that his position in what touches upon his way of understanding God "has no intention of overlooking the perceptions of Greek metaphysics by appealing to the Bible," nor is he willing to defend "a metaphysical God." 1

The nature of revelation

My analysis of Küng's understanding of truth, God, and reality is intended to underline the dynamic and historical character that our author attributes to each of them. In what concerns God, he stresses the secularity and the historicity of the divine. God does not exist in a separate, extra- or suprahistorical realm, far-removed from the dimensions of time and space. This does not mean, however, that küng denies the transcendent, metaphysical dimension of God. I hope this has been clearly established. In questioning a two-floors theory of the structure of reality (a theory which proposes an ontological $x^{\omega} p(\sigma \mu$ ós between our realm of "becoming" and the divine realm of true "being"), Küng is trying to assert that the world in which we live belongs basically to the same reality in which God moves and acts. The dimension of space and time in which our history develops is not alien to the essence of God's being and existence. ${ }^{2}$

What, in this context, is Ying's understanding of the nature

IMenschwerdung, p. 556.

2This concept can be illustrated by Küng's assertion that for God the future is real. 
of divine revelation? I have addressed earlier l küng's belief in divine revelation as a phenomenon which "does not originate in subjective human experience and reflection" 2 but at the level of the divine. Still, he holds that since "God speaks through humans," 3 the inspiration of the hagiographers cannot mean "the exclusion. repression, or replacament" of their human activity. 4 Thus, we have revelation coming "from above," from God, but at the same time we have divine revelation "continually experienced, interpreted, verffied and then made the object of theological reflection 'from below' by humanity." 5 Divine revelation and human interpretation are not successive but simultaneous phenomena, underlines Küng. God's revelation is given from the outset through the medium of human interpretation and through it only."

Following this line of thought küng can hardly avoid the conclusion that since in different times and cultural setrings there are different "general interpretive frameworks or theoretical models of understanding (paradigms), of which we are more or less

$1_{\text {See above, Pp. } 178 \mathrm{ff} .}$

2 Küng, "New Consensus, " p. 5.

3 Ibid.

${ }^{4}$ Küng, Infallible?, p. 213. Cf. Christian, pp. 461-66, on inspiration; and ibid., Pp. 466-68, on the Scriptures as the word of God. Küng clings to the same view of revelation-inspiration in a more recent treatment of the issue (see "Schrift als Zeugnis der Offenbarung," in Küng, Theologie im Aufbruch, pp. 76-78).

5 "New Consensus," p. 5.

6 Ibid. 
conscious," 1 each community of hearers of the Christian message has to interpre: $i=$ anew when it no longer speaks to them directly. In the specific case of the biblical writings, their authors wrote "within the interpretive frameworks of their environment and the socio-cultural milieu of their age." 2 The gospel is thus clothed in culture and time-bound images, concepts, and frames of reference which at times were "to the detriment of the Christian faith itself." 3 The "interpretaments"4 of the New Testament are for this reason to be analyzed through historical-critical research, especially research into the life of Jesus who is "the source, standard and criterion of Christian faith." 5 This is all the more necessary since Christianity is not founded on myths, legends, or tales, but on "the historical personality of Jesus of Nazareth." 6 Even though Küng grants that the NT writings do not enable us "to reconstruct Jesus' biography," he is confident that we can, for the

I Ibid., Pp. 5-6. "No experience, even in the instance of biblical and ecclesiastical expressions of faith, is without an interpretive framework, model of understanding or implicit theory," remarks küng (ibid., p. 6).

2 Ibid., p. 6.

${ }^{3}$ Ibid.

"Used by Schillebeeckx the term is intended to designate the "specific conceptual or figurative statements of the interpretation" of revelation, i.e., the concrete verbalization of the content of revelation (see ibid., p. 5).

5 Ibid., p. 6.

${ }^{6}$ Ibid., p. 7. This also means that Christianity is not merely a doctrine. 
first time in the history of Christian theology. 1 "gain an insight into the original outlines of the message of Jesus as well as his personal lifestyle and destiny." 2 In addition, he thinks that it should be possible for contemporary believers to trace the "itinerafium mentis" of the first disciples, thus coming to a better understanding of why, after Jesus' death, he was proclaimed as "the living Christ and Son of God." 3

This consideration of Küng's thought helps one to understand why for him the testimony of the NT Canon, even when he deems it methodologically normative for all subsequent Christian theological reflection, does not succeed in presenting unerringly the essence of the gospel, at least not for our time. We must attempt to get to the core of Jesus' message and reinterpret it again, as well as the meaning of his whole life, from the perspective of our time and cultural setting. How sure can we be that in disposing of the "clothing" allegedly belonging to an antiquated paradigm we are not also discarding some elements which are of the essence of the Christian message itself is perhaps the central problem that this approach inevitably poses. Again, it is by identifying the norm or norms of discrimination between essence and form that the problem could perhaps be solved. Küng proposes as the norm and criterion of Christian faith "the living Jesus of history." However, since Jesus

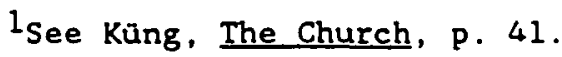

2 "New Consensus," p. 7.

${ }^{3}$ Ibid. 
is not with us any more, we have to rely on the Scriptures ${ }^{1}$ and, according to küng, on the historical-critical methods in order to reach him. This brings us back to our starting point. Küng's "paradigm-change" theory can perhaps offer us a concrete solution to what appears as a circular reasoning. ${ }^{2}$ It may also help us to find an additional, external norm for distinguishing the essence of the Christian faith from its culturally conditioned formuiations.

\section{"Paradigmenwechsel" in Theology}

The "change of paradigns" ("Paradigmenwechsel") in the history of theology and the church is a question "that has occupied me since the end of the seventies," observes küng. ${ }^{3}$ The analysis of paradigms, ${ }^{4}$ developed after Thomas S. Kuhn, ${ }^{5}$ is to some extent "an analysis of the breaks in the history of Christianity, "t though it is not "merely a study in history." It is more than this. Küng thinks that since paradigms of the past still endure in certain

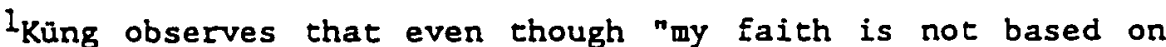
Scripture," because Jesus Christ, not the inspired book, is the ground of falth, "it is in Scripture that my faith in Jesus Christ originates, since this is the testimony of Jesus" (Infallible?. p. 218)

${ }^{2}$ The new concept of God advocated by our author is illustrative of the way in which the "change of paradigms" works.

${ }^{3}$ Küng, "On Being a Christian Theologian," p. 15.

"For a description of the notion of "paradigm" as particularly proposed by Küng, see below, pp. $341 \mathrm{ff}$.

5 See Thomas Samuel Kuhn, The Structure of Scientific Revolutions (Chicago: The University of Chicago Press, 1962; 2nd. enl. ed., 1970).

${ }^{6}$ Küng, "On Being a Christian Theologian," p. 15. 
Christian grcups and churches, "their analysis also permits a precise analysis of the present." 1

It was Kuhn, the American physicist and historian of sclence, Küng observes, who first made a comprehensive study of "the structure of scientific revolutions."2 Küng asserts that Kuhn's main thesis is that radically new theories arise netther by verification nor by falsification but by "the replacement of a hitherto accepted explanatory model (paradigm) by a new one." 3 As to the definition of "paradigm" in Kuhn's volume, Kuhn himself writes:

One sympathetlc reader.. . concluded that the term is used in at least twenty-two different ways. Most of those differences are, I now think, due to stylistic inconsistencies. . . . With that editorlal work done, two very different usages of the term would remain. 4

In one of these two usages, which Kuhn calls "the more global use," 5 paradigm stands for "the entire constellation of beliefs, values, cechniques, and so on shared by the members of a given community. " 6 It is this definition of Kuhn which küng quotes in his application of the concept of "paradigm-change" to theology."

$1_{\text {Ibid. }}$

${ }^{2}$ See Küng, Does God Exist?, p. 106.

3ibid. , p. 107.

${ }^{4}$ Kuhn, "Postscript--1969," in Idem, The Structure, pp. 181-82.

5 Ibid., p. 182.

6 Ibid., p. 175.

7 See Küng, Does God Exist?, p. 107; see also Hans Küng and David Tracy, eds., Theologie--wohin? Auf dem Weg zu einem neuen 
Küng's claim that the paradigm-change theory facilitates one's analysis of "what changed" and "what persisted" in the history of Christianity, 1 sheds light on our study of his position regarding the continuity-and-change component of the orthoroxy-heresy antithesis. Moreover, the Paradigmenwechsel theory describes how a "stubborn resistance" to everything that might result in a change or replacement of the established paradigm is likely to appear. ${ }^{2}$ Changes always provoke resistance. The "conversion" to a new paradigm occurs usually with "the second generation," which sees in a new light what for the former one was "heretical." In this way, the "revolutionary change of certain former basic assumptions," once accepted, transforms what was yesterday's heresy into today's orthodoxy. 3

Küng's first exposition on Kuhn's theory 4 appeared in Does God Exist? in the context of his discussion of the superiority of

Paradigma (Gütersloh: Gütersloher Verlagshaus Gerd Mohn; Einsiedeln: Benziger Verlag, 1984), pp. 21-22, 41.

I Ibid.

${ }^{2}$ Does God Exist?, p. 111.

3Ibld., p. 112. The importance of the paradigm-change theory for the understanding of Kung's concept of orthodoxy and heresy is asserted by our author himself. Reacting to a communication from me concerning the topic of this dissertation, Küng writes: "Wichtig freilich ware mir, dass sie die neuesten Arbeiten von mir zum Paradigmenwechsel in Ihrer Analyse miteinbeziehen. . . . Ich denke also, dass im Lichte der Paradigmenentwicklung sie meine eigene theologische Denkgeschichte, aber auch meine Analyse des Verhaitnisses von katholischer kirche und anderen christlichen Kirchen einerseits und Christenheit und Weltreligionen andererseits besser verstehen können" ("Letter of Hans Küng to Enrị̣ue Espinosa," June 2, 1987).

${ }^{4}$ see above, pp. $339-40$. 
rationality over rationalism. 1 Further explanations of the paradigm-change theory and its application to theology can be found in the most recent books edited by $\mathrm{Kung},{ }^{2}$ and in a volume to which he has contributed. ${ }^{3}$ The issue was also discussed at the International Ecumenical Symposium held in Tübingen, May 23-26, 1983, and attended mostly by theologians belonging to the faculties of the University of Chicago Divinity School and the University of Tübingen. 4

The change of paradigns in the natural sciences

In Küng's opinion, one of the main contributions of Kuhn's "new philosophy of sciencen5 is that it sets forth how we make

Isee the section "Scientific Revolution: Thomas S. Kuhn," in

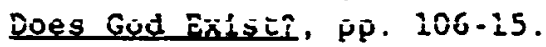

2 See especially Küng, "Was meint Paradigmenwechsel?," in küng and Tracy, eds., Theolegie--wohln? (1984), pp. 19-25; and kün, "Paradigmenwechsel in der Theologie: Versuch einer Grundlagenerklarung," in ibid., pp. 37-75. See also Küng, "Ein neues Grundmodell von Theologie? Divergenzen und Konvergenzen," In Hans Küng and David Tracy, eds., Das neue Paradigma von Theologie: Strukturen und Dimensionen (Einsiedeln: Benziger Verlag; Gütersloh: Gütersloher Verlaghaus Gerd Mohn, 1986), Pp. 205-16; and Küng, Theologie im Aurbruch (1987), pp. 153-250, 253-73.

${ }^{3}$ Kung, "Theologie auf dem Weg zu elnem neuen Paradigma," in Johannes B. Bauer, ed., Entwäfe der Theologie (Graz, Vienna, and Cologne: Styria Verlag, 1985), Pp. 181-207.

"See Küng's and Tracy's "Vorwort," in Theologie--wohin?, Pp. 7-8; see also the special report by one of the participants to that Conference, Martin E. Marty, "Tübingen Models for Theology, " CC 100 (1983):653-56. The symposium was sponsored by the "Institut für okumenische Forschung" of the University of Tubingen, the Institute for the Advanced Study of Religion of the University of Chicago, and the board of the international theological journal Conctifum.

SKuhn's theory has been criticized from different perspectives. In the scientific realm Karl $R$. Popper is one of its most 
"progress" in natural science. ${ }^{1}$ Quoting from Kuhn's The structure of Scientific Revolutions, ${ }^{2}$ Küng points out ${ }^{3}$ that in "normal science" there is progress attained by research which, in turn, is based upon past scientific achievements, all of which constitute "great theoretical constructions." The latter provide models for everyday scientific practice from which particular coherent traditions of scientific research emerge. In other words, they serve as paradigms. Ptolemaic and Copernican astronomy, Aristotelian and Newtonian dynamics are examples of sets of opposed "paradigms on a grand scale." It is important to notice that, in practice, "students accept such paradigms less as = result of proofs than because of the authority of the textbook and the teacher."

Next to the "greater paradigms," 4 one can also find concrete "puzzle solutions" which can be described as paradigms. "Normal scientific research," according to Kuhn's theory, consists in practice in "puzzle solving," i.e., in finding additional material to make the accepted model more precise. In other words, the real interests of "normal science" is more in a cumulative growth of

outspoken critics. On the discussion between Kuhn and Popper's followers, see Imre Lakatos and Alan Musgrave, eds., Criticism and the Growth of Knowledge (Cambridge: Cambridge University Press, 1970).

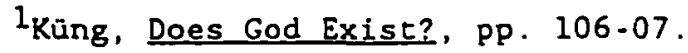

2 see above, p. 339, n. 5 .

${ }^{3}$ In what follows, we are quoting from Does God Exist?, p. 107.

${ }^{4}$ These paradigms on a grand scale are the ones which Kuhn defines as "an entire constellation of beliefs, values, techniques, etc., which are shared by the members of a given community" (Kuhn, The Structure, pp. 175, 181-91). 
knowledge than in producing anything radically new. If "anomalies --new, unsuspected phenomena"1...are detected in a given scientific field, an attempt is made to fit these into the existing paradigm. "Instead of falsifying the theory, an attempt is made to modify it, to correct it, to formulate it in a new way." 2 However, the increasing precision and expansion of the existing paradigm, and the growing complexity of the theory are the very things which at one point lead to its undermining rather than to the consolidation of the paradigm. When this occurs, the time has come for a paradigmchange. ${ }^{3}$

\begin{abstract}
Several characteristic points of Kuhn's paradigm-chaiige process must be stressed: (1) "A period of pronounced insecurity generally precedes the emergence of new theories, which in the end leads to the destruction of the paradigm. "4 The usual condition for the final rejection of an accepted paradigm is "crisis." (2) Kuhn observes that as soon as a paradigm has proved itself, scientists are rarely interested in seeking alternatives. Nevertheless, when
\end{abstract}

IDoes God Exist?, p. 107; emphasis Küng's.

2Ibid., pp. 107-108. "Scientists at first show no slight resistance to anything new. . . which might result in a change of the paradigm, of its categories or of its operation, "explains Küng (ibid., p. 107). He also notes that in their general resistance to change of the greater paradigms, the scientists often simply wait or even try to discredit the discoverer of anomalies as "a disturber of the peace" (ibid., p. 108).

${ }^{3}$ Küng cites the increasing knowledge about the movement of the stars which caused the Ptolemaic system to be replaced by the revolutionary theory of Copernicus as an example of this idea. The Efnsteinian revolution has produced a similar result.

${ }^{4}$ Does God Exist?, p. 108 . In what follows we are quoting from this page. 
the decision is made to reject a hitherto accepted paradigm, it always coincides with the acceptance of another. (3) The transition to a new paradigm does not come about gradually as in the "normal science" process of gathering information. It is a "sciencific revolution." (4) The two paradigms, the old and the new, become incompatible: The old must yield to the new. This means, in practice, that established and familiar concepis are changed, "norms and criteria are displaced." 1 The total world-picture, as in the cases of Galileo and Darwin, is changed. Paradigm changes, notes Kuhn, "cause scientists to see the world of their researchengagement differently. " 2

Küng draws several conclusions from Kuhn's scientific theory of paradigm-change: (1) Most important is the need for an "epistemological relativizing of scientific knowledge." 3 In fact, observes küng, in natural science "great care is taken today... . not to regard as absolute either the anethod applied or the truth perceived." 4 So, he notes, not even in physics may the assumption that "nature can be known as it really is" be held. (2) As a result of new discoveries in connection with the theory of relativity and quantum mechanics, "modern physics starts out from the assumption that the conclusions of classical physics hold not in themselves but

It surely can be perceived that the issue of change of "norms and criteria" of truth (in this case scientific truth) caused by the shift of paradigm is of central importance for our query.

${ }^{2}$ Kuhn, The Structure, p. 87.

${ }^{3}$ Does God Exist?, p. 110.

${ }^{4}$ Ibid. , p. 109. 
only under certain conditions." 1 (3) Hence today, in the natural sciences, one customarily speaks not of "universally valid truths copying reality" but of hypothatical "paiterns" that hoid true only by virtue of "certain conditions and within certain limits. "2

(4) In brief, "an absolutely objective truth is not envisaged but only one that is relatively objective." 3

In addition, the "hyper-Cartesian rationality of an abstract positivistic logic and linguistic analysis" has been appreciated as too narrow an approach to reality. It has now become abundantly clear, observes Küng, that there is little excuse for making "the mathematical method and mathematical truth absolute (monism of method)."4 In fact, notes he, the development of the theory of knowledge over the past fifty years has led back again to the dimensions of history, psychology, sociology, and even metaphysics. The pronounced antidogmatism of the logical-critical approach, remarks Küng, led to "a new dogmatism, which is not open to criticism." 5 The theory of paradigm-change allows us to appreciate that, conversely, "no simple criterion," "no single rigid theory," "no single great paradigm" is adequate to judge the whole reality or the entire process of scientific progress. 6

IIbid.

2 Ibid., pp. $109-110$.

3 Ibid., p. 110.

4 Ibid., p. 109.

${ }^{5}$ Ibid.

6 Ibid. 
347

In the paradigm-change theory küng finds further confirmation of the accuracy of his view on the complexity of truth and reality. In his opinion this scientific theory provides interesting parallels with the way in which he sees progress being made in theology.

Theology and changes in tha world picture

It is scarcely possible to deny that in philosophy and theology there are also "scientific revolutions," remarks Küng. 1 This is certainly true, for instance, of the Cartesian and Kantian turning points in the history of philosophy. What about the history of theology? Küng recognizes that the idea of theological revolutions is at odds with the emphasis by the official church on continuity, identity of teaching, 2 and even infallible teaching. However, Küng asks, did not the great Greek theologians Clement and Origen, and later Augustine, produce what in many ways was a new pattern of interpretation, a new paradigm? Was not the acceptance of Aristotle by Thomas Aquinas an equally significant revolution? What shall one say of Lucher in relation to the theology of the Middle Ages, and of the Enlightenment and historical-critical theology in relation to the theology of the Reformation? ${ }^{3}$ These,

IIbid., p. 111.

2 See above, pp. 90-91, about the semper eadem view.

${ }^{3}$ Does God Exist?, p. 111. In connection with the issue of the application of Kuhn's theory to the history of the church and its theology, Mark A. Noll observes that Kuhn's discussion of "normal science," "paradigm shift," and "revolutionary" situations has been "applied promiscuously to far too many historical 
holds küng, can be considered as "far-reaching changes in the history of theology and the church on a large scale." 1

In the light of this analysis, Küng proposes a tentative "periodization" 2 which he considers basically "In harmony with the Eamiliar world-, church-, and historical-theological periodization." 3 Küng's periodization ${ }^{4}$ of th? paradigm-changes in the history

developments." In his opinion the theory seems to fit, however, in what has to do with the shift from "a period in which normal science proceeded under a secure paradigm (the Bible is the Word of God to be interpreted by the conventions of common sense)," to a period when "anomalies in the old theories seemed to proliferace (new knowledge about world religions, new conceptions of historical development, new advances in research, new standards of professional study--and all exacerbated by social and economic changes in the community experiencing the anomalies)." Noll visualizes a brief period of dialogue between those working in the old paradigm and those struggling to impose a new one, taking place about 1880 to 1900. Under the new paradigm, "the Bible, however sublime, is a human book to be Investigated with the standard assumptions that one brings to the discussion of all products of human culture." The first generation which accepts the new paradigm, that is, the first generation after the "revolution," then looks upon those who cling to the old paradigm "as almost literally beneath contemp:." livii concludes that, "however helpful a consideration of paradigm shifts may be in describing what went on, it is far less useful for evaluating the truth-claims of the participants" (Between Faith and Criticism: Evangelicals, Scholarship, and the Bible in America (San Francisco: Harper \& Row, Publishers, 1986], p. 45).

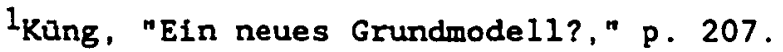

2Ibid.; emphasis is Küng's. This seems the best translation to the German word "Perlodisierung."

${ }^{3}$ Ibid.

${ }^{4}$ See the diagrams which explain graphically this "Periodisierung," in Küng, "Was meint Paradigmenwechsel?," p. 25; and idem, "Theologie auf dem Weg zu einem neuen Paradigma," p. 207. Both diagrams are identical and bear the title "Paradigmenwechsel in der Geschichte von Theologie und Kirche." Küng states that the papers dealing with Jrigen and Augustin. Thomas and Luther, and with old Protestant dogmatics and new Protestant doctrine of the faith, all of which were presented at the Tübingen International Ecumenical Symposium in 1983, have Inspired him to try to periodicize the 
of the church and theology distinguishes six basic models or "macroparadigms." 1 He lists them as follows:

(1) In the first century A.D. we have the period of Judeoctsastianisy with the "classical theological" authors. This period corresponds with the "early Christian-Apocalyptic paradigm" which shared an "apocalyptical-eschatological general constellation" of beliefs. 2 Küng holds that this paradigm is obviously obsolete. ${ }^{3}$ From a modern standpoint, in the "completely changed horizon of understanding of humanity today," we must admit that "the apocalyp. Eic framework of linderstanding" has been superseded by historical developments. 4 He sontends that it is well known that the course of history prophesied in the book of Daniel in the four-empires scheme "has been discredited by history itself and then also abandoned in modern times." 5 This apocalyptic horizon "cannot and should not be artificially resuscited today," warns Küng, as not only "Adventists and Jehovah's Witnesses, but sometimes also . . . political

paradigm changes of theology and church (see Küng, "Was meint Paradigmenwechsel?," p. 19). See also Küng, "Ein neues Grundmodell von Theologie?;" and idem. Theologie in Aufbruch, pp. $153 \mathrm{ff}$.

Infor reasons of explanation and distinction, I would like to call these great epochal paradigms or basic models macroparadigms," observes Küng. They include a large number of "mesoparadigms" (like the two-natures Christological doctrine and the soterlological doctrine of satisfaction of Anselm) and also "micro. paradigms" (see Küng, "Was meint Paradigmenwechsel?," p. 21).

2 "Was meint Paradigmenwechsel?," p. 20.

${ }^{3}$ Ibid., p. 23.

${ }^{4}$ Küng, Eternal Life?, p. 92.

SIbid., p. 90 . 
theologians" try to do. 1 The horizon of apocalyptic ideas was characterized by two main beliefs, namely the expectation of the imminent coming of God's kingdom and the belief in the resurrection at the end of rime. ${ }^{2}$

(2) The second macro-paradigm, according to Küng, corresponds to the period of the "early Catholisism" of the Greek and Latin fathers, especially the late first and second centuries. In this "ancient-church Hellenistic paradigm" the main figure is origen, and key words are "tradition" (paradosts) and "fathers" (patres). ${ }^{3}$

Kunng notes that even though such theologians as Irenaeus, Clement, Origen, Tertullian, Cyprian, Athanasius, and the Cappadocians differ in their theologies, they use jointly "an entire constellation of beliefs, values, techniques and so on, shared by the members of a given community. "4 The community in this case, Küng says, must be understood as the community of theologians and as the community of the church. The constellation of beliefs, values, and techniques of this period "was quite different from the

IIbid., P. 92.

2Ibid., pp. 89-92. Cf. Pannenberg, "Dogmatic Theses," p. 147.

${ }^{3}$ Küng, "Was meint Paradigmenwechsel?," p. 25. Cf. the historical-theological survey above, pp. 50-64.

${ }^{4}$ Ibid., p. 20. Küng quotes Thomas $S$. Kuhn's definition of paradigm. He also makes clear that, "In one paradigm several theologies are possible" (Ibid., p. 22). 
apocalyptic-eschatological entire constellation of the original Judeo-Christian church." 1

(3) The third macro-paradign küng calls the "medieval-Roman Catholic paradigm." The turning point for this paradigm shift is Augustin and the main figure of this medieval period is Thomas Aquinas. Key words which characterize this period are "ecclesia" and "papa. 2

Kung observes that even though Augustin, Anselm, Abelard, Thomas, Bonaventura, Scotus, and Ockham follow different methodological ways, they all reflected the overall basic model of understanding of heir medleval epoch, a model that was quite different from both the early Christian apocalyptic and the Greek and early Latin church fathers' models of understanding. ${ }^{3}$ This paradigm is characterized by the Gregorian reform. It is the "scholastic and canonistic" model of Roman Catholic theology which flourished particularly toward the eleventh century.

(4) After the reformatory councils of the fifteenth century, the following century saw the rise of a new paradigm which kung labels "the Protestant Reformation paradigm." Major figures here

I Ibid., p. 20. About some of the theological characteristics of this paradigm, see Kung's views on the Hellenization of Christian theology above, pp. 325-35.

${ }^{2} \mathrm{Cf}$. the historical-theological analysis of the components of orthodoxy-heresy above, chapter 1 , the sections on the ecclesiastical criterion of orthodoxy, on the emergence of the issue of infallibility, and on infallibility and the truth of the Christian doctrine.

${ }^{3}$ Küng, "Was meint Paradigmenwechsel?," p. 20. CE. idem, "Paradigmenwechsel in der Theologie," p. 45; and idem, "Theologie auf dem Weg," pp. 181-83. 
are Luther and Calvin. Key words are "Word of God" and "inerrancy" of the Scriptures. ${ }^{1}$ Again, Küng points out that even though Luther, Zwingli, and Calvin had their theological strifes, it remains true that theirs was a completely different model of understanding compared with the typical medieval Roman Catnolic model of theology and church. 2 The reformers' was a "revolutionary biblical-rhrisencentric new conceptio- of the whole theology." 3

Two secondary paradigms are described by küng as subsets of the "Protestant Reformation paradigm." They are the "medievalcounterreformatory-Neoscholastic Roman Catholic"4 and the "Protestant-orthodoxy" paradigms ${ }^{5}$-.though these in turn would suffer a crisis which the Swiss theologian describes as being generated by the Enlightenment and the historical-critical theology in their objecting to both the "systematic-speculative Scholasticism" of Roman Catholicism and the "biblicist" Protestant orthodoxy. 6

l"Was meint Paradigmenwechsel?," p. 25. CF. Küng, "Theolorie auf dem Weg," pp. 188-91; idem, "Paradigmenwechsel in der Theologie," p. 50 .

${ }^{2}$ Küng, "Was meint Paradigmenwechsel?," p. 20.

${ }^{3}$ Küng, "Paradigmenwechsel in der Theolngie," p. 50.

${ }^{4}$ See Kūng. "Theologie auf dem Weg zu einem neuen Paradigma," pp. 183-85; idem, "Was meint Paradigmenwechsel?," p. 25.

${ }^{5}$ Küng, "Was meint Paradigmenwechsel?," p. 25; see also idem, "Faradigmenwecissel in der Theologie," p. 50. Though these two models are ideologically opposed, they represent a hardening of the positions of both Catholics and Protestants as a result of the "revolution" of Luther and Calvin. Roman Catholics answered the Protestants with the Counter-Reform, while Protestant Orthodoxy stressed the inerrancy of tha Bible.

${ }^{6}$ Küng, "Paradigmenwechsel in der Theologie," pp. 50-51. 
(5) In the "modern-times-Enlightenment paradigm" of the seventeenth and eighteenth centuries, whose major exponent was Schleiermacher, "theology could no longer be conducted as in the times of the Reformation and of the Protestant orthodoxy." 1 The key word here is "reason." From the beginning of the modern times and under the influence of the new rationalistic-empirical philosophy and the natural sciences, the theologies of Scmler, Reimarus, Schleiermacher, Baur, Ritschl, Harnack, and Troeltsch, even though different from one another, shared the common trait of questioning both Protestant biblicism and Catholic neo-Scholasticism associated with the older paradigns.

(6) Finally, in our twentieth century and coexisting with Orthodox, Roman Catholic, and Protestant "traditionalisms,"2 as well as with the liberal theology detived from the modern-Enlightenment paradigm, we have the "contemporary paradigm" which includes the dialectical, existential, hermeneutical, political, and liberation (feminist, black, third-world) theologies.

The basic issue at stake raised by the International Ecumenical Symposium which gathered at Tübingen in 1983 was precisely whether there was such a thing as a new paradigm or basic

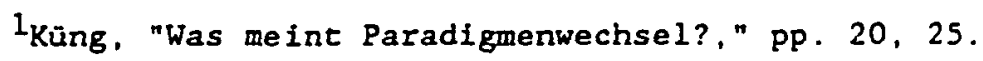

2 Referring to the five macro-paradigms mentioned above, Küng observes that "in all these cases-. in discontinufty and in continuity!--innovation finally turned into tradition. To be sure: when the great historical processes of transformation are ignored, then tradition turns into traditionalism. One tries to preserve the old model of understanding" ("Was meint Paradigmenwechsel?," p. 20; emphasis in the original). 
model of theology? "And if so, do we need it today?"l In spite of all the different theories, methods, structures, and theologies (such as those mentioned above), Küng asks,

[Are there! any unchangeable constants which run through this paradigm like a golden thread which any Christian theology must presuppose if it wants to he a scientific, responsible and justifiable record of the Christian faith? ${ }^{2}$

While an answer to this question is unquestionably related to the fact that "the criteria for a new paradigm would have to be discussed more thoroughly in the future, 3 one thing remains sure. thinks Küng; namely, that "we are in the midst of a transition from the modern to a post-modern paradigm." 4 This "post-Enlightenment or post-modern paradigm, which we cannot yet designate with a keyword," 5 is characterized by a crisis on several levels in the social, political, and economic world, not to mention the potential destruction of humankind and its environment. It is also characterlzed by social antagonisms such as exploitation, oppression, racism, and sexism. In the theological realm, the contemporary crisis reveals that a "shaking of the dominance of Christianity as the 'only true,' 'only saving.' 'absolute' religion" for the first time

${ }^{1}$ See Küng, "Ein neues Grundmodell von Theologie?," p. 205.

2 Ibid.

${ }^{3}$ Ibid., p. 210.

${ }^{4}$ Küng, "Theologie auf dem Weg," p. 199; emphasis in the original.

${ }^{5}$ Ibid., p. 208. 
has allowed an encounter of Christianity with "other religions on the level of 'approximate equality'. "l

All in all, those who attended the Tübingen symposium emphasized time and again that "the problem of continuity in a paradigm-change deserves special consideration in Christian theology."2 It is "the old gospel and none other" which must be interpreted afresh for our time. ${ }^{3}$ The one constant which in all paradigm-change of theology has to maintain its place is "the Christian tradition, the gospel, the faith in God and in Jesus Christ."4 In Küng's opinion, however, "the gospel and the New Testament have to be distinguished from each other." He remarks that his stay and research at the University of Tübingen has made this clear to him. 5

To conclude, the Swiss theologian asserts that in "a new ecumenical paradigm," two constants of theology must be kept in mind. First is "the basic norm of a critical ecumenical theology." This is the Christian message itself, "the gospel of Jesus Christ, which comes from Jewish tradition." This basic witness has found its expression "In the Scriptures of the Old and New Testaments" and Is "totally focused on the living Jesus of history, who is also the

I Ibid., pp. 210-11; emphasis kung's.

2Küng, "Ein neues Grundmodell von Theologie?," p. 212: emphas is his.

${ }^{3}$ Ibid. ; emphasis in the original.

4 Ibid.

${ }^{5}$ See "Theologie auf dem Weg," p. 192. 
norm and the criterion for my very personal, Christian faith." I The second constant in a new paradigm can be expressed as Ecllows: "In order to be a contemporary theology it must face the present world and open itself to the world'e needs and hopes." In other words, the new horizon of a "critical ecumenical theology is our present world of experience in all its ambivalence, contingency, and changeableness. " 2

The question raised at the end of chapter 3 seems to have found an answer: on the one tand, the historical and scientific ways of thinking, characteristic of the $1980^{\prime} \mathrm{s}$, adopted as the preeminent norms of truth, and, on the other hand, Küng's application of the paradigm-change theory to the history of theology and the church (to explain how today's heresy may become the next paradigm's orthodoxy) are both regarded as playing a determinant role in the way by which, in his view, Christian truth must be determined. In fact, it is the contemporary paradigm as "a whole constellation of beliefs, values, and techniques" which has, in practice, preeminence over the paradigm of the biblical times. At the end, it seems that from the original apostolic witness as recorded in the NT, we can rescue "the gospel" alone, which is reduced to a minimum core, i.e., not even the proclamation of the Jesus of history but those aspects of his proclamation in which he was not, due to his sharing in the paradigm of his time, mistaken.

Ibid., pp. 194-95; emphasis in the original.

2Ibid., pp. 196-97; emphasis is Küng's. 
The dynamic and historical notion of truth, reality, God, and revelation held by küng, as well as his use of Hegel's dialectical way of reasoning, help to support his views just Jescribed.

My task in the concluding chapter is to summarize the findings of this study and to appraise Küng's model of orthodoxy. heresy as described and analyzed thus far. Special actenzinn is given to his criteria and norms of Christian truth. Küng's notion that an one-sided and selective approach to the totality of revelation, in particular to the NT Canon, are in essence heresy--a view which he stili noids today ${ }_{-\ldots}$ is also addressed. Some critical questions are raised in the context of the paradigm-change theory as well. The dissertation concludes by pointing to some areas where further study is possible and necessary regarding both küng's concept of doctrinal truth-error (orthodoxy-heresy) and the antithesis of orthodoxy-heresy in general. 97-108.

1See Küng's Theolegie in Aufbruch (published in 1987), pp. 


\section{CHAPTER V}

SUMMARY, CRITIQUE, AND CONCLUSION

In the preceding chapters I have endeavored to describe and analyze Hans Küng's model of orthodoxy-and-heresy, paying special attention to his criterla and norms of Christian truth. The historical-theological outline of the development of the orthodoxyheresy antithesis presented in chapter 1 gave us a chance to consider both Küng's understanding of the principles, criteria, and norms of orthodoxy identified there and his position concerning the main theological issues related to the antithesis.

Chapter I had an additional purpose. It was aimed at discerning the connections existing among the constitutive elements of the orthodoxy-heresy structure. The attempt was thus made to come to a comprehensive and organic perception cf this complex issue in order to carry on a well-founded analysis and critique of Küng's views. I deemed such a comprehensive understanding helpful to clarify both the rationale and the implications of Kung's position on the question of Christian truth and error.

This survey not only provided the loci I needed for an appropriate study of Küng's model of orthodoxy-heresy but, in underscoring the historical and organic interconnection that exists among them, it also suggested a logical sequence for the treatment of Küng's views. 


\section{The Structure of the Orthodoxy-Heresy Antichesis}

Chapter 1 identified both traditional and modern criteria and norms of orthodoxy, 1 as they appeared throughout the history of the Christian church, among the constitutive elements involved in the structure of the orthodoxy-heresy antithesis. These were considered along with the principles undergirding them and some relevant theological issues, again traditional and modern, zalated to the general problem of the church's definition of doctrinal truth and error.

A definition of the manner in which the terms "principle," "criterion," and "norm" are used in this dissertation was necessary. By "principle" I referred to the fundamental, primary, and general context undergirding the criteria and norms of orthodoxy. In other words, principles were regarded as essential concepts which serve as a general frame or context to understand those criteria and norms. In a sense, it might be held that the criteria and norms of orthodoxy are derived from those principles. As for the terms "criterion" and "norm," though in vernacular discourse they may often be synonymous. In these pages a distinction was made between them as far as the issue of orthodoxy-heresy is concerned. By "criterion" I intended to designate that which enables one to decide

The separating line distinguishing between "traditional" and "modern" criteria, norms, and issues is approximately the time of the Protestant Reformation. The Renaissance, the Reformation, the Enlightenment, and the French Revolution may be considered as parts of the process by which authority and tradition (i.e., the two principles undergirding the traditional criteria and norms of orthodoxy) became questionable. 
whether a doctrinal proposition is true or false. I have used the term in the broad sense of the grounds, basis, or means for judging the legitimacy of Christian doctrines. The criteria of orthodoxy are thus related to the basis on which a particular doctrine is affirmed to be true or false (orthodox or heretical). In brief, criteria are understood here as those general and abstract areas of reality where the elements which guide the believers in their testing of Christian truth are grounded. On the other hand, the term "norm" has been used to designate specific and concrete standards of Christian truth over against the more general and abstract nature of a criterion. In this usage, norms 3 re regarded as concrete expressions of a given criterion. Norms are explicit models or patterns against which a particular doctrine can be measured in order to verify its orthodoxy.

As a particular example of this differentiation, I have considered authority as the general principle undergirding both the revelational and the ecclesiastical criterfa of orthodoxy, while the principle of tradition (or, more specifically, of successiontradition) stands behind the ecclesiastical criterion. As far as the revelational criterion is concerned, it means that the general basis on which early Christians accepted their dnctrines as legitimate was the bellef that they had been delivered through revelation. The teaching of the apostles and the New Testament Canonl were regarded as concrete expressions of the revelational

IThroughout this dissertation, Canon has been used as synonymous of Scriptures. 
criterion--to the extent that their content was believed to have been uttered by divine revelation-inspiration. They were, therefore, specific norms which made it possible to decide the authenticity of any alleged Christian belief or teaching.

In summary, chapter 1 made it plain that the conflicts over some specific doctrinal points, mainly Christological at the beginning, served as a catalyst for the gradual development of certain criteria by which the early church sought to distinguish legitimate from false bellef and teaching. The two outstanding criteria of Christian truth which appeared early in the scenario of Christiail theology were the revelational and the ecclesiastical criteria, in that chronological order. These I labeled the "traditional" 1 criteria of orthodoxy.

Both criteria found expression in some coricrete norms of orthodoxy. In the context of the revelational criterion, the teaching of the apostles came to be the first such norm. As a consequence of the recognized authority of the apostles and after their death, a corpus of neotestamentarian apostolic writings was regarded as a sound norm (the second norm of classical orthodoxy).

The original apostolic tradition was believed to have found embodiment also in an oxal form which was kept and passed on by the disciples of the apostles--the principle of tradition. Controversies about who possessed the authentic oral tradition necessary to interpret correctly the canonical Scriptures brought torth the idea that the former was preserved, by the grace of the spirit, in the

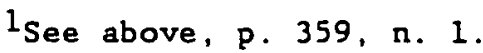


catholic (universal) ecclesia, specifically in those churches which stood in the succession of the apostles. This view constitutes what has been retained in this dissertation as the second traditional criterion of orthodoxy: the ecclesiastical criterion. The oral traditionst of the church constituted a soncrete norm (the third norm of classical orthodoxy) in which the ecclesiastical criterion found expression. Those traditions were considered to be orally summarized in the "rule of faith" or "canon of truth" which, in turn, was the forerunner of the writien creeds of the early church. ${ }^{2}$ From the ecclesiastical crterion of correct doctrine, added to the undisputed teaching authority of the apostles, was later derived the fourth norm of classical orthodoxy: The bishops came to be viewed as the successors of the apustles, and thus the pronouncements of the eplscopal Magisterium wera regarded as normative.

In this context, two theological issues appear as paramount in the Middle Ages. The institutional consolidation of the church after the conversion of the emperor Constantine led the authority of the post-apostolic ecclesiastical traditions and that of the pronouncements of the episcopal Magisterfum to overpower in practice the authortty of the canonical scriptures. Due to both religious and political reasons and thanks to the power achieved by the episcopacy, the notions of the catholicity and unity of the church

$1_{A}$ distinction is made here between tradition as a fundamental principle related to the transmission of the Christian message and the specific traditions of the church as a norm of orthodoxy. For further reference to the various nuances of the term tradition, see above, p. $38, n .1 ;$ p. $51, n .1$; and p. 59, n. 1 .

${ }^{2}$ CF. Gilles, The People of the Creed, pp. 48-49. 
were emphasized. Ecclesiastical unity was enforced, which resulted in an increasing monolithic unity of the doctrine of the official church. Variation from the approved version of Christian doctrine was regarded as herctitai. In addition to the importance of the unity of the church's doctrine, the charismatic infallibility of the Magisterium was stressed in an attempt to affirm the truthfulness of the ecclesiastical teachings.

The principles, criteria, norms, and theological issues reviewed thus far are the main constitutive elements of the orthodoxy-heresy structure which appear clearly delineated toward the end of the Middle Ages. During that period of time heresy was defined not merely as false teaching, when measured against the norms of classical orthodoxy, but as a sin against church and state, Indeed essentially as "non-church."

The Protestant Reformation constituted a revolutionary turning point in the history of the Christian church and theology. For one thing, the confrontation between the Catholic and the Protestant positions raised in a clear way the relativity of the concepts of orthodoxy and heresy. To Roman Catholics, the Reformers seemed to claarly fit the category of heretics since they adopted views contrary to the Roman Catholic worm of truth, 1.e., the teachings of the ecclesiastical Magisterium. To the Reformers, on the contrary, these views could hardly be described as heretical since they understood them to be in accordance with what they regarded as the norm of truth, the Bible. 
Apart from the issue of the relative application of the categories of orthodoxy and heresy, the Protestant Reformation brought about a crisis in the formerly potential tension between the revealed and the ecclesiastical norms of orthodoxy. In the confrontation between the normative authority of the Canon and the insights and truth-elaims of post-biblical traditions that developed in the Christian communities-co which an authoritative and normative status was also attributed by the church--one perceives a conflict between the "original deposit"l of Christian belief and the agent transmitting and interpreting the truths of revelation, i.e., the ecclesiastical Magisterium. Translated into epistemological terms, this was a confilct between the object of knowledge and its subject or agent.

Moreover, on the one side, the Protestant allegation that the Roman Catholic Church had departed widely from the original norms of Christian truth, and, on the other, the Roman Catholic insistence on the authority of the Magisterium brought the tension exlsting between these two norms of orthodoxy into a deadlock. The more Protestants contested the teaching authority of the Roman Catholic Church, the more Catholics stressed it. Evidently, the impasse had to do with the interpretation of the original deposit of faith by the church. Again in epistemological terms, it was an impasse involving the interpretation of the object of knowledge by

lsince in Roman Catholic theology the deposit of faith is defined as consisting of the canonical scriptures and sacred Tradition (see the Vatican II Constitution on Divine Revelation, art. 10, in Abbott, Docs, of Vatican II, p. 117), my designation "original" deposit refers to the Scriptures alone. 
the agent. Protestants stressed the infallibility of the original deposit alone, while Roman Catholics added to it the infallibility of the agent. Though both parties agreed as to the infallible authority of the canonical scriptures, they differed in their appreciation of the infallibility of the teaching authority of the church. The problem of defining doctrinal truth and error was thus being opened to the interpretative level. 1 There was need for a "hermeneutical" criterion able to address the problem of truth without restricting its solution to two factors--object and agent-of theological knowledge, 1.e., to the content of the original deposit and the teaching authority of the church.

A new hermeneutical criterion was offered to the theological community in the change of presuppositions or basic assumptions which emerged in the Western world from the eighteenth century on. Thi= change brought forth $a$ new world-view which challenged the classical and medieval transcendent, timeless, and static notion of ultimate reality and truth. In contrast with the two-tiers theory of the structure of reality ${ }^{2}$ prevailing until then, the dominant "Weltanschauung" of the post-Enlightenement period came to be historicism, i.e., the dynamic and temporalistic conception of the

1Any epistemological structure contains three elements or factors: The object of knowledge (what is to be known), the subject or agent (the one who knows), and the interpretative process itself. In the structure of the orthodoxy-heresy issue, these elements correspond to the original deposit of faith, the Magisterium of the church, and the interpretative criterion employed by the Magisterium, respectively.

${ }^{2}$ On the two-tiers theory, see above, pp. 97, 104, 130, 133135 passim. 
world which tended to view all knowledge and all forms of experience in a context of historical change and development. 1 The new historical consciousness ${ }^{2}$ involved a dynamic understanding of reality (i.e., a non-static ontology) which, in turn, entails a relativistic epistemology. 3

In this context, the theories of the development of dogma became an important issue in the theological fielt They urderlined the fact that many of the dogmas which the churches presented as eternal truths handed down essentially unchanged since the apostolic times had often had their origin in later historical circumstances. The concepts of doctrinal truth and error thus acquired a more relative value. As a result, the call for a nondogmatic and more pluralistic Christianity has brought to the foreground the idea of the inappropriateness of such concepts as orthodoxy and heresy.

Not surprisingly, the issue of the truth and infallibility (or fallibllity) of Christian doctrine and that of its continuity and change were Identified in this dissertation as the most salient

1so Karl Mannheim, "Historismus;" and Ernst Troeltsch, Der Historismus und seine Probleme. For a brief treatment of the shifts in the meaning of the term "historicism," see Mandelbaum, "Historicism," The Encyclopedia of philosophy (1967), 4:22-25.

2 Mandelbaum points out that the modern world is often characterized by its historical way of thinking (The Problem of Historical Knowledge, p. 1).

${ }^{3}$ Historical relativism, notes Bultmann, is primarily the product of Romanticism. The latter denies that a universal human reason which could conceive truths of absolute timeless value exists at all. The "historical school," being "the offspring of pomanticism," with its conception of reality as a historical process finds objecticnable the idea of absolute truth (Bultmann. The Presence of Eternity, Pp. 9-10). 
theological issues of the post-Reformation period as far as the orthodoxy-heresy antithesis is concerned.

As for the hermeneutical criterion of truth stressed in the context of the new historicist world-view, it was identified in this study as the "scientific" criterion. It means that the modern scientific mentality recognizes as true that which can be stated on the basis of an objective establishing of the facts. 1 Modernity is indeed characterized by the questioning of traditional authorities. the depreciation of tradition in general, and the articulation of a new norm of truth ${ }^{2}$ in accordance with the modern scientific criterion.

The modern scientific criterion found concrete expression in the historlcist approach. In contradistinction to early Christians, who believed they had found the truth in the revelation of an eternal and transcendent God, and classical Greek and Hellenist philosophers, who discovered the truth in the blossoming of the eternal in the spatio-temporal realm, modern man sees truth existing In the concrete dimension of history. ${ }^{3}$ Historicism is thus a 1Ernest Cuneo notes tnat the sclentific method of knowledge
consists essentially of observing the object to which it is to be
applied, inventing an hypothesis which tends to explain the
observation, and checking the hypothesis against further observation
(Science and History, p. 7 ). ${ }^{2}$ So M. A. Gillespie, Hegel Hefdegger and the Ground of History, P. 8; and R. Bultmann, The Presence of Eternity, P. 7 .

${ }^{3}$ Following Dilthey, Croce and their disciples, Gillespie describes historicism as the assumption that history is not merely one realm of being but all reality and that there is nothing behind, beneath or above history (Hegel. Heiddeger, and the Ground of History, P. 18). 
definite scientific-philosophical conception of reality. For that reason it was regarded in this dissertation as a concrete norm in which the scientific criterion finds expression. For the sake of convenience, without any intent of lessening the distinction I made between criteria and norms. I bring up the "scientific-historical criterion," thus referring both to the primary appreciation for the scientific criterion of truth and to the historical way of thinking characteristic of modern man. ${ }^{1}$ According to the historical way of thinking, any specific formulation of a Christian doctrine is only relatively true. In other words, doctrines express truth to the extent that they are understood in their time-conditioned and culturally conditioned context.

The consideration of the modern criterion and norm of truth and the theological issues related to orthodoxy-heresy just reviewed completed my outline of the main constitutive elements of the orthodoxy-heresy structure in chapter 1. The following step, in chapter 2, was to describe the main theological traits of Hans Küng. Chapters 3 and 4 described and analyzed Küng's understanding of the constitutive elements of the orthodoxy-heresy antithesis.

One finds in the remainder of the present chapter a summary of Küng's attitude toward the traditional and zedern prisciples, criteria, norms, and issues of orthodoxy, followed by a critical evaluation of his own criteria and norms of Christian truth.

1 "There are two great intellectual forces in the sodern world, science and history, and while they often seem mutually antagonistic they are in fact fundamentally complementary." So writes Gillespie (Hegel. Hefdegger, and the Ground, p. ix). 


\section{Küng's Criterla and Norms of Chrisclian \\ Iruth: A Review}

Chapter 2 underscored the leading concerns which constitute the starting point of Kung's theology. Pastoral in nature, these concerns were identified as his interest in contributing to the ecumenical understanding among all Christian traditions and his preoccupation for proclaiming the gospel in terms both intelligible and relevant to modurn humarkind. The latter concern may be regarded as explaining Küng's theological shift from a precritical to a historical-critical approach to exegesis and dogmatics, which includes his change of perspective from a theology "from above" to a theology "from below."l His "decision in favor of scientific theologym2 must also be understood in the context of this pastoral concern.

The outine of the history of the church and theolngy presented in chapter 1 from the perspective of the orthodoxy-heresy antithesis divided that history into three main periods. The first period, from the inception of Christianity down to the time of the Council of Nicaea, corresponds to the formation of classical orthodoxy. The second colncides with the consolidation of the ecclestastical criterion of orthodoxy during the Middle Ages. The last period starts with the crisis originated by the Reformation and includes the issues and criteria of truth which have appeared in the last two hundred years or so. In recent years küng has been

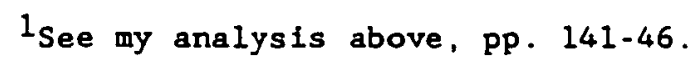

2Küng, "On Being a Christian Theologian," The Critic 41 (Summer 1987):12. 
analyzing the same historical developments from a different perspective, namely, that of the "Paradigmenwechsel" in theology.l He distinguishes $\mathbf{s i x}$ periods or macro-paradigms: the apocalyptical, Hellenistic, medieval, Reformation, Enlightenment, and post-modern. The paradigm-change theory bears upon the orthodoxy-heresy issue to the extent that, in Küng's view, it explains how "the whole constellation of presuppositions, beliefs, values, etc.," shared by the Christian community and particularly by the theoiogians, have fluctuated when "revolutions" occurred which replaced the old paradigm by a new one, thus making the old obsolete and at the same time introducing a new orthodoxy. In Küng's analysis, it is usually the defenders of past paradizms who tend to deem the new interpretation heretical.

Interestingly enough, Küng's paradigm-change theory may likewise be applied to his own theological development. In this context, Küng compares his decision in favor of scientific theology with a stone thrown into the water causing concentric circles to spread out. In his case, three concentric circles may be distinguished, corresponding to the decades of the sixties, seventies, and eighties, In which concentrations on first ecclesiological, then Christological, and finally more global flelds ${ }^{2}$ have taken place, in that order. 3

Ion the Paradigmenwechsel theory, see above, pp. $339 \mathrm{ff}$.

${ }^{2}$ Küng's interest in more global fields is revealed in his inter-religious and inter-disciplinary dialogues. Theologian".

${ }^{3}$ See Küng's own auto-analysis in "On Being a Christian Reproduced with permission of the copyright owner. Further reproduction prohibited without permission. 
In correlation with the gradual widening of Küng's areas of interest from issues mostly restricted to Roman Catholicism to those of interest to all of Christianity and, eventually, to all of humanity, his primary norm and standard of Christian truth has undergone some modiflcations. 1 In the context of his methodological stress on the normativity of the Scriptures over against tradition, ${ }^{2}$ Küng increasingly put his emphasis into "the gospel," 3 which, as we noticed, he distinguishes from the NT Canon. ${ }^{4}$ Indeed, it might be held that küng retains the scripture as "the locus" or primordial source of Christian bellefs and teachings, while the gospel constitutss the center of his personal falth. He has lastly emphasized a two-fold norm, i.e., "the living Jesus of history" and "our present world of experience" as the two constants of theology in a new paradigm. 5

My analysis in chapter 3 suggested that Küng's stress on the normativity of the Scriptures over against tradition took place in the context of his intra-Catholic discussion, which was centered mostly on ecclesiological matters. In his dialogue with Protes-

$1_{\text {Kung himself acknowledges that "the original center" of his }}$ theology (1.e., his "fundamental Christian conviction which is rooted in the gospels") "has not remained untouched" by the concentric circular development of his thought (see küng. "On Being a Christian Theologian," pp. 16, 12).

2 The preaching of the apostles "as it has come down to us in the writings of the New Testament" is "valid for all time," observes Küng (The Church, p. 456)

\footnotetext{
${ }^{3}$ See Küng, "New Consensus," p. 14.

${ }^{4}$ Küng, "Theologie auf dem Weg," p. 192.

SIbid., pp. 194-97.
} 
tants, however, Küng underlined the "catholicity" of the $\mathrm{NT}^{1}$ and questioned the selectivity and one-sidedness which, in his view, is characteristic of Protestantism. The latter's one-sided approach to the Canon, he noted, is of the essence of "heresy." In a typically dialectical fashion, during the second circle of his theological development, kung underlined the normativity of the gospel and of jesus Christ himself ${ }^{2}$ over against either a "traditionalistic" ${ }^{3}$ or a "biblicist" approach. In the same context, he emphasized that the Scriptures, in particular those of the NT, must be understood from a historical-critical perspective if one wants to know the message of the real, historical jesus. Finally, in his inter-religious dialogue and in his dealings with the concerns of the secular mind, kung continues to advocate the "old gospel, "5 this time, however, stressing the necessity of the latter to be interpreted afresh from the perspective of the totality of human experience.

${ }^{1}$ As, for instance, in his discussion with Protestant theologians KAsemann and Diem. See above, pp. 190-200.

${ }^{2}$ Catherine LaCugna observes that Küng has not chosen any doctrinal center for his hermeneutic (no canon within the Canon, like kasemann did with the doctrine of justification). Rather he has placed "a living person" at the center, Jesus Christ himself (LaCugna, Hethodology of küng, p. 213, n. 28). position.

3hich is, in Küng's view, the typical Roman Catholic

${ }^{4}$ Namely, the traditional Protestant position. I must add that, as described by Küng, this "biblicist" approach seems to be that of fundamentalist Protestants.

${ }^{5}$ Küng, "Ein neues Grundmodel1?," p. 212. 
The Traditional Criteria and Norms of Orthodoxy

It was within the first circle of his theological development, when he concentrated on ecclesiological matters in the historical context of the ecumenical awakening of the Roman Catholic Church, that küng dealt with the princlple of religious authorfty, regarded in my analysis as the fundamental ground undergirding the traditional criteria and norms of orthodoxy.

Küng's leading pastoral concerns (1.e., the reunion of Christianity and the credible presentation of the gospel to modernminded humanity) compelled him to confront the Roman Catholic model of authority advocating "a renewed authority," i.e., one aware of both what is involved in the "original Christian message" and required "at the present time." 1 Though he explicitly stated that "We are not speaking against authority in the Church, but for it, 2 Kung was also careful to potnt oul litis lise koman Catholic way of exercising religious authortty constituted the number one stumbling block to Christian unity. ${ }^{3}$ For one thing, our author proposed an

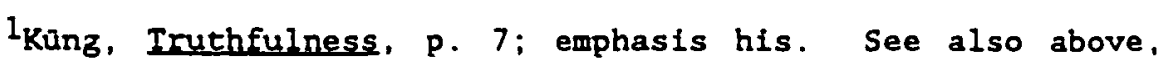
pp. 158ff. This two-fold concern of kung (namely, a "return to the sources" and a sensitivity for modern requirements) is clearly reflected in his dogmatic (systematic) thought. His doctrine of Christ, for instance, eventually questioned the "high" Christology built upon the theological thought of Barth and the philosophical views of Hegel. According to küng himself, this high Christology lacked adequate foundation in the historico-critical examination of the New Testament sources, as well as in the self-understanding of modern man in the light of contemporary reality" (Küng, "On Being a Christian Theologian," p. 13).

\section{Inuthfulness, p. 7.}

${ }^{3}$ See, for instance, Küng, The Council, pp. 128-29; idem, Council in Action, p. 197. 
attitude of the church's Magisterium which would reveal its evangelical and servant nature rather than an authoritarian one. 1 For another, he advocated the duty of theologians to assist the Magisterium in its teaching activity through the discernment, by scholarly means of modern research, of whether the church speaks correctly of God. 2 Küng's scientiflc criterion of Christian truth already showed up here, a criterion which he wanted to harmonize with the principle of authority: Even though in the church "theology cannot take the place of authorfty," neither can the latter be "a substitute for theology, ${ }^{3}$ remarked he. In implying that the teaching of theologians and the episcopal Magisterium stand in a relation of equality, our author came into direct confrontation with the Vatican. 4 At the bottom was the issue of Kung's questioning the special charism of infallibllity which Roman Catholics believe has been granted to the Magisterium of the church.

Always within the context of the principle of authority and within the bounds of his intra-Catholic discussion, Kung stressed the norms related to the revelational criterion of Christian truth over against those belonging to the category of the ecclesiastical criterion. Even though he may not have dealt at length with the doctrine of revelation nor with the relationship existing between

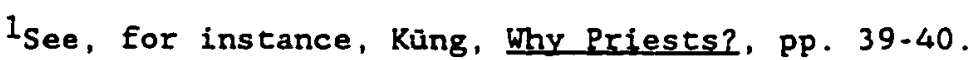

${ }^{2}$ Küng, Freedom TQday, p. 82. See above, pp. 160-65.

${ }^{3}$ Ereedom Today, p. 82.

${ }^{4}$ See the CDF's letter to Küng, dated March 30, 1974 (U.S. Catholic Conference, The Kung Dialogue, pp. 78-84). 
his own view of revelation and the traditional revelational criverion of orthodoxy, his confessed ultimate norm of Christian truth falls within the reaim of the latter criterion: it is the Bospel of Jesus Christ as originally proclaimed by the apostles and recorded in the NT Canon. When asked by Joseph Cardinal Höfner by which authority he professed his opinions, 1 Kung answered that it was "by the authority of the Word of God which I, an a theologian, must serve."2 striking a typically Protestant note, ${ }^{3}$ he consistently held that the church wust. always look for guidance in the orlginal gospel of Jesus Christ himself "as reflected in the Scriptures." 4 In his eyes the proclamation of the apostles is "the fundamental and, for all time, standard-setting testimony of Jesus Christ." 5 In the church's search for a measure of constant renewal. "the only concrete guide is the apostolic church."6 küng thus emphasized the foundational and normative nature of the apostles' proclamation and teaching, 7 as recorded in the NT Canon.

1Letter of Cardinal Höffner to Hans Küng, December 23, 1974 (see Küng Dialorue, pp. 90-91).

${ }^{2}$ Letter of Hans küng to Cardinal Hoffner, January 10,1975 (Ibid., pp. 91-92).

${ }^{3}$ Protestants and Catholics alike have observed that Küng's view on doctrinal authority is close to the traditional Protestant position (see, for instance, Kiwiet, Hans Kung, p. 12; and J. J. Hughes, "Hans Küng and the Magisterium," IS 41 [1980]:379).

${ }^{4}$ See, for instance, Kung, The Church, p. 456; 1dem, Mainrained, p. 40: and Idem, "New Consensus," p. 14.

5küng, Strfuctures, p. 177.

6 Küng, The Church, p. 439.

7 Ibid. , pp. $451-59$. 
As a corollary, Küng regarded the norms of orthodoxy which fall within the scope of the ecclesiastical criterion (namely, the post-biblical or sub-apostolic oral traditions and the pronouncements of the Magisterium) as the norma normata of Christian truth, i.e., as secondary to the normativity of the original sources of the Christian faith. True, both the original apostolic teaching and the Canon of the New Testament belong to the tradition of the church and came into existence within the Christian community.1 Yet, he stressed the fact that the post-apostolical or extra-biblical traditions derive their normative value from the normativity of the original sources. The Swiss theologian insisted that "Sacred Scripture is thus the nerma nermens of the Church's tradition, and tradition must be seen as the norma normata. " 2

Regarding the agent transmitting the Christian message, Küng contends that it is not just a few individuals in the church bicialichy but, as in the NT times, the whole assembled community that has the decisive word in matters of doctrine. The apostolic succession thus involves the whole people of God rather than the episcopate alone. As for the authority which the bishop receives through apostolic succession, in Küng's view it is related more to the bishop's spiritual accomplishment as magister than to his historical genealogy.

IIn this sense küng appreciates the value of ecclestastical tradition for the task of ascertaining true Christian bellef and teaching. In fact, he explicitly describes tradition as one of the main "criteria of Christian truth" (see Küng, Maintained, Pp. 39-46; see also above, chapter 3, part 2, [pp. 201ff.]).

2The Church, p. 36 . 
In addition, Küng observed that errors and false developments have indeed occurred within the Roman Catholic tradition. One of the bases for recognizing wrong deveiopments as such is precisely the original deposit of faith. He thus denounced, at times, the unscriptural basis of the ecclesiastical tradition.

Küng's attempt to bring fellow Roman Catholics to acknowledge the existence of errors in the church tradition as well as his effort at reinterpreting the coricept of the infaliibility of the church have been aimod, primarily, at removing what he sees as two stumbling blocks for contemporary men and women. (1) On the one hand, for a number of modern-minded Catholics (and non-tathclics alike) the errors of the Magisterium are a major hindrance to their acceptance of the message of the church. Kung Found it necessary to disclaim the infallibility, avowed by Roman Catholicism, which :as based both on the special charism conferred by Christ to the apostles and their successors and on the notion of the sacramentalmystical nature nf the apostolic succession. This strategy led him to show, on a neotestamentarian basis, that no special charism was granted to "the twelve" which made them incapable of error. He also argued from a philosophical perspective (particularly in his volume Infallible?) against the "a priori" infallibility of any human proposition. He applied these insights first to the pronouncements of the Magisterium and, in a subsequent step, to the biblical formulations. (2) On the other hand, Kung sees the dogma of the infallibility of the Magisterium as a scandal for Protestants who would otherwise be willing to live in closer communion with the 
Roman Catholic Church. Thus, his interest in ecumenism must also be counted among the principal causes compelling küng to examine critically the Catholic concept of magisterial infallibility which, from a Protestant perspective, was the chief stumbling-block for reunion.

As far as the issue of the unity of church doctrine is concerned, Küng again questioned the official teaching of Roman Catholicism. He noted that true unity of the body of Christ is not achieved by merely denouncing a dissenter's position and, after qualifying it as heresy, by proceeding to silence if not destroy him. The church should rather pay attention to the concerns of heretics and be prepared to correct whatever is necessary in the light of the gospel of Jesus Christ. In this way, the church would grow in its apprehension of truth and should be able to prevent unnecessary breaks in the body of Christ. Of particular significance is the fact that, in Küng's view, the antithesis churchheretics cannot be simply equated with the truth-error antithesis. There is truth and error in both positions whether of traditional "orthodoxy" or of various dissenters. In küng's view, therefore, "heresy" is not to be understood merely as error but also, and mainly, as selectivity and concentration in particular aspects of Christian doctrine. ${ }^{1}$

${ }^{1}$ Kung considers that "a selection from the totality of Revelation.. . is, precisely, heresy" (The Counc1l, p. 112; emphasis his). See also Council in Action, p. 172; The Church, pp. 40, 318-19; Theologie im Aufbruch, pp. 97-108. 
From what has been considered thus far, Küng's model of orthodoxy-heresy, succintly stated, presents two main features. First, as he noted more particularly in his dealing with a catholic approach to the Canon, the prime characteristic of heresy is selectivity, one-sidedness, and concentration on a farticuiar dimension of the Christian truth. This is basically opposed to the catholicity or universality which küng deems essential to the legitimate Christian teachings. Second, while affirming that heresy endangers the unity of the body of Christ 1 -a typical Roman Catholic concern-he states that heresy should not be measured against a "supposedly correct (orthos) system" of doctrine but against the gospel, "the true message of salvation." 2

In conclusion, even though küng recognized the normative value of ecclesiastical tradition for the task of ascertaining true Chrlstian bellef, he has questioned those developments in the tradition of the Roman Catholic Church which, in his view, are not in harmony with the scriptures. Still, since he thinks that the Bible "Is not without faults and errors, murky and muddled sections, IImitations and mistakes," 3 historical criticism is necessary, especially since we live at a time when "a completely new scientific world viston has come to prevail" and when "there is no longer any eternal truth that can evade the critical judgment of reason by

IUnlike some contemporary theologians, Küng recognized the validity of the category of heresy, though not exactly in the same terms as in the Roman Catholic Canon Law.

${ }^{2}$ Küng, The Church, p. 315.

${ }^{3}$ Küng et al., World Religions, p. 32. 
appeal merely to the authority of Bible, tradition or Church." 1 Therefore, even though küng does not deny the validity of the principles of authority and tradition--from which the traditional revelational and ecclesiasticai criteria of orthodoxy are derivedhe stresses the necessity of using the principle of criticism which stands behind the modern scientific-historicist criterion of truth.

The Criterion and the Norm of Truth

In a Modern Perspective

The dogmatic implications of an exegesis which follows the historical-critical approach came to light in a most clear fashion within "the second circle" of Küng's theological development. 2 This stage, whici occurred in the seventies, was marked by a concentration on Christological questions. ${ }^{3}$ Küng's aim at that time was the presentation of a constructive theological response to the challenge of atheism and secularism. 4 He realized that "It was not solely Catholicism that was at stake, but indeed Christian existence--in the context of a secularized, polycentric, multi-religious, and widely post-Christian world." 5

$1_{\text {Küng, Eternal Life? }}$, p. 6.

2One should keep in mind, however, that in Küng's ecclesiological work during the sixties, the historical-critical approach had already yielded specific dogmatic results.

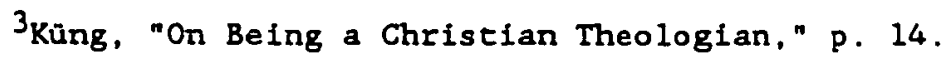

"Küng's most significant volume on that issue, Does God Exist?, was published in 1978 .

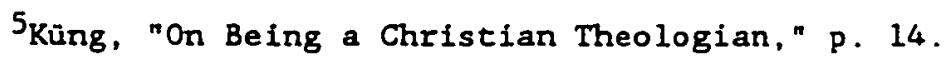


In this context--as may be seen precisely in his Christology--Küng's emphasis was more apologetical than dogmaifcal. Desirous to show why the Christian message is to be preferred to both contemporary secular humanism and other world religions, he deemed it necessary to clarify what is essentially specific to Christianity. 1 The essence of Christianism--that which, being the "soul" of the church, must remain throughout all changes--is not an idea, nor a principle, a fundamental assertion, or basic attitude. It is "a person, it is Jesus Christ himself." 2 Moreover, it is the "real" Christ, namely, Jesus of Nazareth, "the one wh.s lived in this real history: the historical Jesus." ${ }^{3}$ In his search for the authentic original message of the historical Jesus, 4 the historicalcritical methods of exegesis were regarded by küng as unavoidable. These methods helped him to distinguish between the "essence" and the "form" of dogma, and, at the same time, to derive some dogmatic conclusions which constituted küng's response "to the challenge of

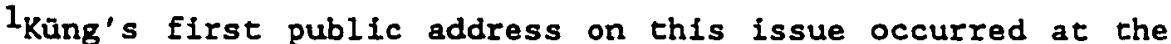
International Theological Congress of Brussels in 1970 (see Küng. Bleiben muss, p. 9). His position was published in a brief "theclogical aeditation" (the volume just quoted), and later in one of his major works, On Being a Christian, published in its original German version in 1974.

2 Küng, Bleiben muss, pp. 33-34; emphasis his.

3 Ibid., p. 37 ; emphasis in the original.

${ }^{4}$ As for the message which Jesus proclaimed, Küng points out that it was not identical with the message of the church. The church proclafmed Jesus as the Messiah and Son of God (Bleiben muss, p. 45). Jesus, on the contrary, proclaimed the approaching kingdom of God and the will of God as the supreme norm (ibid., pp. 39-40). 
historical criticism." 1 It is precisely from a dogmatic perspective that Küng's Christological views encountered, once more, much criticism and opposition: this time not solely from the Catholic but from the Protestant camp as well. Kung claimed that even though certain culturally and time-conditioned aspects of a dogma may be forsaken, the permanent truth of lts core affirmation can be rescued and retained. In the specific case of Christology, he holds that the core of the biblical message, which as such must be retained, consists in the belief that jesus is-functionally rather than essentluily or ontologically.-the definitive revelation of God in the flesh. He considers that

In the New Testament, Jesus Christ is primarily viewed not as an eternal, intradivine hypostasis, but as a human, historical person concretely related to God: the ambassador, Messiah, word of the eternal God in human form. 2

The tendency to put Jesus, as the Son of God, "on the same level of being as the Father" was the result of the spread of Christianity to the world of Hellenistic thought, remarks Küng. ${ }^{3}$ He explains that beyond the fact that Jesus proclaimed the kingdom of God, the will of God as the supreme norm, and the gospel--which kung simply defines as "the good news of the free forgiveness of God, "4 almost everything else which the Christian dogma affirms of Christ, starting from the Christology of the "later writings" of the New

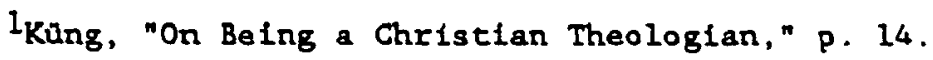

2 Küng et al., World Religions, p. 120.

${ }^{3}$ Ibid., p. 118 .

${ }^{4} \mathrm{Küng}$, Bleiben muss, pp. 39-41. 
Testament ${ }^{1}$ and following with the definitions of church councils (especially Nicaea and Chalcedon), belongs to that culturally conditioned "form" of Christian doctrine which is characteristic of ancient times and which may be replaced by contemporary formulations. In general terms, then, the question at stake-.s difficult one sndeed-is to decide what is the historically conditioned expression and what belongs to the unchangeable essence of the Christian message. In order to justify one's decision, whatever it may be, the criterion and the norm which prevails is the key question.

In the case of Kung, it turned increasingly evident that his hermeneutical criterion, namely, the modern scientific-historicist criterion, has become ultimately decisive for his definition of Christian truth. Though he has time and again stated, explicitly and implicitly, that the canonical Scriptures are the norma normans non normata for Christian doctrine, ${ }^{2}$ it should be clear that for hin the Scriptures have normative value only when used as a means of gaining access to the essence or substance of the Christian faith, namely, the actual Jesus of history and his original message. ${ }^{3}$ The NT Canon, then, no longer functions as canon in Küng's model of orthodoxy-heresy, at least not in the way it did for the early

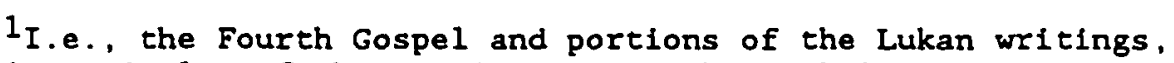
the Pauline epistles of the captivity, and the catholic epistles.

${ }^{2}$ This is one of the principal cenets in LaCugna, Methodology of Küng. See, for instance, Küng, "New Consensus," p. 17; and idem, Theologie im Aufbruch, p. 87.

${ }^{3}$ See Küng, "New Consensus," pp. 6-8; cf. Avery Dulles, Models of Revelation, p. 196. 
church. For küng not all whIch is contained in the NT documents can be retained today as the measure for assessing Christian truth. This is so not merely regarding the culturally determined way of expressing theological ideas, 1 but, as in the case of the Christology of the fourth Gospel whlch kung questions, regarding some aspects of the very theology of the New Testament as well. This view makes it difficult to distinguish, throughout the history of the church and theology, heresy from orthodoxy in a clear-cut manner.

A word must be said now regarding the third and outermost circle of Küng's theological development which began to form itself at the beginning of the eighties focusing on the problems of humanity in general. During this decade, our author has been particularly occupied with the question of the religions of the world and the interreligious dialogue. ${ }^{2}$ Not entirely unrelated to this "global-ecumenic" concern ${ }^{3}$ is Küng's dealing with the paradigmchange theory, another major motif in his writings since the end of the seventies. ${ }^{4}$ His main concern in this area has been how to

In the biblical writings, holds Küng, we find the essence of God's message clothed in culturally and time-conditioned forms ("New Consensus," p. 6).

2One of Küng's concerns in this sense is that "Without religious peace, there is no world peace" (see kung et al., World Religions, Pp. 440-43; "On Being a Christian Theologian," p. 14).

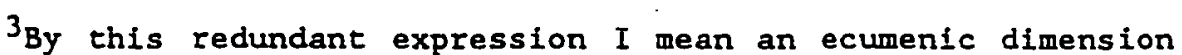
which goes beyond the realm of Christianity to include other worldreligions.

${ }^{4}$ See Küng's own statement in this sense, in "On Being a Christian Theologian," p. 15. 
interpret in a global perspective the present crises in the economic, political, social, ecological, and other fields of general interest, as well as their relation to the religious situation of our time. 1

Küng believes that, in accomplishing the task of anncuncing the gospel in our contemporary times.

Today's theologian will have to think in a global perspective if he is to do justice to an epoch of growing international. interconfessional, and interreligious dependency, and of an awakening global consciousness in matters of Church and ecumenism. 2

In this context, it is not difficult to understand why "the living Jesus of history" and "our present world of experience," which according to küng are the two constants of theology in a new paradigm, ${ }^{3}$ constitute his two-fold norm of Christian truth. Küng seems to present in dialectical synthesis his confessed ultimate norm of Jesus Christ himself (and his gospel) and what I have identified as the criterion represented by the modern scientifichistoricist world-view.

From the perspective of the paradigm-change theory, Küng's description of what he calls the "early Christian-apocalyptic paradigm"4 provides us with another test case ${ }^{5}$ for assessing his

InHow can we describe our own time? Post-enlightenment? Post-modern?," asks Küng (lbid.; cf. Küng. "Theologie auf dem Weg," pp. 199,208 ).

2 "On Being a Christian Theologian," p. 16.

${ }^{3}$ See Kung, "Theologie auf dem Weg," pp. 194-97; also "New Consensus," PP. 5, 11.

${ }^{4}$ see above, pp. 349-50. 
declared position regarding the normativity of the NT Canon. Küng notes that the apocalyptic-eschatological horizon of understanding pecullar to the NT times became obsolete in the Hellenistic paradigm (the second paradigm of his periodization), and so remains today. The apocalyptical-eschatological world-view, therefore, would not belong to the essence of the Christian message. Indeed, Küng evaluates the eschatological-apocalyptical expectation as a mistaken bellef belonging to an obsolete paradigm. ${ }^{1}$ According to him. some specific beliefs which were acceptable within the horizon of apocalyptic ideas, have been superseded by modern developments in the "completely changed torizon of understanding of humanity today." 2 Among these bellefs were, primarily and foremost, the expectation of the imminent coming of God's kingdom and the belief in the resurrection at the end of time. ${ }^{3}$ for one thing, "we no longer live in imminent expectation of the end of the world," observes Küng. ${ }^{4}$ For another, he holds that the belief in the resurrection of the Messtah, which belongs to the apocalyptical

$5_{A}$ test case briafly considered earlier in this chapter is Kung's view regarding the nature of Cirist.

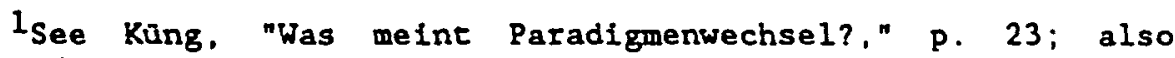
Eternal Life?, PP. 89-92.

2 Eternal Life?, p. 92. 147.

${ }^{3}$ Ibld., pp. 89-92; so also Pannenberg, "Dogmatic Theses," p.

"Küng et al., World Relifions, p. 30; emphasis Küng's. That the end of the world will eventually come can be held also on the basis of curzent scientiflc theories, observes king (Elernai Life?, PP. 206-07). 
horizon of understanding, must be recognized today as erroneous to the extent that the resurrection was not "a historical event." 1

In this context, Küng's ultimate norm of orthodoxy, again, cannot be said to be the literal text of the canonical Scriptures. Nor is it the proclamation of Jesus Christ as recorded in the NT, since Küng regards the eschatological proclamation of Jesus Christ, along with the early church's eschatological expectancy of the kingdom of God, as mistaken. ${ }^{2}$ This seems to confirm that the decisive criterion of truth, for küng, is of a hemeneutical nature and corresponds in his particular case to the present sclentifichistorfcist horizon of understanding.

The model of orthodoxy-heresy advocated by Küng thus seems to present a difficulty which can be expressed in the following rerms: Heresy, which according to him can be basically defined as a selective approach to the Christian message, is to be measured against the gospel of Jesus Christ as originally witnessed to in the

1Efernal Life?, p. 105. Nevertheless, Küng assures us, the resurrection of the Lord is "a real event." On the difference between the historicity and the reality of the resurrection, see my discussion below.

${ }^{2}$ Kung explains that since Jesus shared in the hortzon of apocalyptic ideas of his time, he lived, like many of his contemporaries, in "a state of apocalyptically depicted imminent expectation: the kingdom was to come." Küng remarks that with Christ "an entire apocalyptic generation was expecting in the immediate future the kingdom of God . . . and was mistaken" (Eternal Ifife?, p. 92; emphasis his). Jesus and his contemporarles were mistaken in the sense and only in the sense that generations of human beings vere 'mistaken' in their belief in the Ptolemaic world picture before Copernicus" (ibid.). By this kung means that they were mistaken as far as their world-view was concerned, which would imply that the hope of the kingdom of God should be reinterpreted (demythologized) for our time in the context of our own horizon of understanding (ibid., PP. 92.95 passim). 
New Testament writings. Küng himself, however, holds that these writings share in the "time- and culture-bound images, concepts and frames of referencen 1 characteristic of their time. To bridge the gap between the conceptual frame of the biblical times and our own, and to recover "the orlginal outlines of the message of Jesus, $n 2$ Küng has come to trust the historfaal-critical approach to the biblical text. Since, by definition, historical criticism works with the central assumption that the accounts of the Scriptures do not necessarily describe things as they factually happened, ${ }^{3}$ it is necessary for the exegete who relies on these methods to constant 1 y discriminate between scriptural statements. This discernment Implies a "selection" within the Canon of Scriptures, a principle which, though in a different sense, Küng regards as heretical and thus condemnable. This, of course, would mean a crucial inconsistency in Küng's model of orthodoxy-heresy. The following critique of Küng's criteria and norms of Chrlstian truth addresses, among other things, this particular problem.

\section{Küng's Criteria and Norms of Christian}

Iruth: A Cettique

The task of criticizing Kung's theological views on the issue of orthodoxy and heresy is far from simple. As it has become increasingly clear throughout the dissertation, Küng's viewpoint is

$1_{\text {Küng, "New Consensus, " p. } 6 .}$

2 Ibid., p. 7.

${ }^{3}$ So Raymond E. Brown, Biblical Exegesis and Church Doctrine (New York/Mahwah: Paulist Press, 1985), p. 11. 
many-sided and, for this reason, often resists reductionism. Truth, holds Küng, is dynamic, dialectical, and multiform. What makes a critique of küng so elusive is precisely his dialectical way of understanding truth and reality. In his own definition, "dialectics, with its inherent contradictions and incongruities is the manner of movement characteristic of history and of the structure of human consciousness." It would not be surprising, therefore, if sometimes Küng sounds inconsistent with his own statements on a given topic. An additional and simpler explanation for some discrepancies between statements in his corpus of writings may be found in the fact that his viuws have at times undergone a radical shift, as indicated earlier in this dissertation. 2

Küng's dialectical way of thinking shows up in his understanding of the traditional norms of Christian truth. When faced with a methodological choice between the original sources of Christian doctrine and the latter's continuity through the living tradition of the church as the ultimate norm of orthodoxy, he recognized the value of tradition as a guideline for the church's falth, but questioned its ultimate normativity when contrasted with the original deposit of faith. ${ }^{3}$ still, in kung's view, the original apostolic tradition, as it has reached us in the literal text of the NT, does not have the ultimate word when interpreted in the context

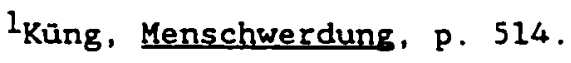

2 See above, pp. $135 f f$.

${ }^{3}$ Küng remarks that tradition "cannot be a dividing line beyond which orthodoxy ends and heterodoxy begins" (The Church, p. 610). 
of the modern horizon of understanding either. It might be soncluded that in Küng's model of orthodoxy-heresy, the authority of the living tradition and that of the canon is affirmed, then dialectically denied, and finally surpassed in a typical Hegelian fashion. 1 More specifically, the ultimate normativity of the Scriptures is affirmed and denied at the same cime, then elevated to a superior unity which in Küng's model is represented by the gospel of Jesus Christ understood through a scientific hermeneutical criterion.

In relation with Küng's criteria and norms of Christian truth, some critical questions must be asked. First, I address what I pointed out as a possible inconsistency in Küng's model of orthodoxy-heresy, mamely, the tension between his basic definition of heresy as a selection from the totality of Revelation and his own selective approach to the New Testament. In doing so I have an opportunity to evaluate critically what criteria and norms are decisive in Küng's interpretation of the Christian message. Second, I evaluate Küng's theory of paradigm-change in theology. This theory is crucial to comprehend how Küng views the manner in which the change-and-continuity of the Christian message occurs, in particular, how the change in the horizon of understanding of the past makes certain beliefs obsolete. pp. $305 f f$.

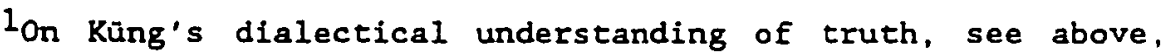
Reproduced with permission of the copyright owner. Further reproduction prohibited without permission. 
Selective? An Inquiry

Even though he has unambiguously affirmed that the Holy Scriptures are the norme nemans of Christian truch, 1 küng has zuestioned some of the fundamental beliefs of the early church as recorded in the NT Canon. As examples, I mentioned earlier Küng's attitude toward the divine pre-existence of Christ, ${ }^{2}$ the historicity of the Lord's resurrection, and the eschatological-apocalyptis expectancy shared by Christ and the neotestamentarian church. His critical interpretation of these biblical doctrines which involves the rejection of their literal meaning, strikes one as a case of discrimination within the Canon, an attitude which he himself at an earlier stage described as fundamentally "heretical" when he shallenged the approach of Kasemann and Diem to the New Testament and accused them of selectivity.

The critical questions which must be made at this function are the following: (1) We should find out whether küng considers that he is treating the NT Canon selectively and thus falling into

Isee, for Instance, The church (1967), p. 36; "New Consensus" (1979), p. 17; and Theologie im Aufbruch (1987), p. 87.

2Notice Küng's remarks concerning the pre-existence of Christ as recorded in the New Testament: "New Testament scholarship has. . . shown how different are the Christologies one finds even In the New Testament. . . . The late, fourth Gospel, which shows signs of Hellenistic influence, has Jesus speak of the glory he had with God before the world was made (John 17:3), a passage that even conservative exegetes do not accept as spoken by the historical Jesus. The first three Gospels, on the other hand, know nothing of Jesus' preexistence. . . [and] Luke uses old, traditional material that completely subordinates Jesus to God." These Lucan statements, Kung notes, "with their 'adoptionist' coloring" represent what was "the faith of Christians--of Jewish Christians" (see Küng et al.. World Religions [1985, Eng. trans. 1986], p. 122). 
the same error as his Protestant colleagues. Does there eaist, in his view, an inner inconsistency in his model of orthodoxy-heresy? (2) If an inconsistency is judged to exist, Would it mean that küng has forsaken his concept that selectivity is of the essence of heresy, and that, in consequence, his critique of Kasemann, Diem, and Protestantism in general finds itself invalidated? If this is not the case, Would it be that, according to küng's definition, his own interpretation of the Scriptures should be considered heretical? (3) The question needs to be raised also as to the rationale for Kung's (supposedly) selective approach to the canonical Scriptures. Is it due to his stress on hermeneutical criterion? Is Küng's selectivity due to the particular hermeneutical criterion of truth used by him, namely the scientific-historicist? Is the use of the historical-critical methods of exegesis the cause of the theologlan's apparent selectivity, as some have suggested?

In relation to the last question, the Conference of German Bishops reacting to Kang's theology in its Declaration of February 17. 1975.1 suggested that the Swiss theologian's discrimination between texts of the NT was due to his historical-critical approach. Already there, the bishops pointed out that inistorical-critical exegesis, though indispensable as a help, involves the potential danger of being selective in the use of the biblical data. Catholic

1 The Declaration was issued at the termination of the doctrinal proceedings of the CDF relative to Küng's volumes The Church and Infallible?. For the complete text of this Declaration, see Künz Dialogue, pp. 94-98. 
faith, recalls the Conference, lives out of "the whole of Scripture." In what sounded as a statement drawn from one of Küng's own books, the bishops noted that a truly Catholic approach does not permit a "onesided or even an exclusive preference for some, most 'earlier' layers, nor does it permit discrimination against later scages of development" within the New Testament Canon.

Also detecting a problem of methodological nature in Küng's use of the historical-critical exegesis, Catherine LaCugna suggests that the Swiss theologian indeed makes historical criticism replace tradition as the authoritative interpreter of the scriptures. 1 Moreover, In LaCugna's view, Küng seems to put historical criticism above the Scriptures as well, despite his alleged intention not do so. 2

In addressing this problem, it must be kept in mind that in one of his early volumes küng wrote about those undertaking a "reform of doctrine" as people who all too often

. . thought themselves called to give a new form to the Christian revelation, according to their own needs and prejudices and without reference to any Church or tradition, so as to formulate, in accord with the spirit of the times, some sort of incorrupt "essence of Chrietienity." "Reform of doctrine" in this case means, in practice, a selection from the totality of Revelation; which is, precisely, heresy. ${ }^{3}$

In another essay of his, dealing with "Early Catholicism" in the NT, ${ }^{4}$ küng criticizes the abandonment of the "wholeness" of the

1LaCugna, Methodology of Küng, pp. 173, 177-79, 203-04.

2 Ibid., pp. 173, 174-77, 182-95.

3 kung, The Council, p. il2; emphas is his.

${ }^{4}$ Namely, "Early Catholicism in the New Testament as a 
New Testament in favor of the concentration afforded by "selecting." Finding his colleague Ernst Kasenann an exponent of "selection as a matter of principle," küng notes that

It is not, obviously, that Kasemann wants simply to eliminate certain texts, or even books, from the Canon of the New Testament; rather, they are to remain in the Canon and, in their fashion, to be given serious consideration. Kasemann does not stand for any selection in this sense. But he wants to 'discern' between the spirits of the New Testament. 1

It is precisely this discernment of spirits within the NT that Kung finds unacceptable. He considers as imperative a "Catholicity in the interpretation of the New Testament."2 Being "one thing," with all its diversity, the NT Canon must be understood comprehensively, rather than "using the lack of unity in the Canon to make a selection from the Canon." 3 To give up the wholeness of the NT in favor of the concentration afforded by selecting, implies, in his view, the abandonment of catholicity in the understanding of the Scriptures in favor of heresy. ${ }^{4}$ The catholic attitude which Küng defends "strives to preserve a full openness and freedom

Problem in Controversial Theology," included in council in Action, pp. 159-189, and incorporated again, with no substantial modifications, in theologie im Aufbruch, pp. 87-109. For my analysis of Küng's position in that essay, see above, pp. 190-98.

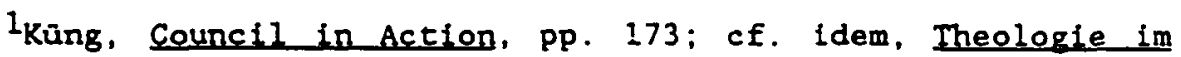
Aufbruch, p. 99 .

${ }^{2}$ council in Action, p. 170; Theologie in Aufbruch, pp. 102 108 .

${ }^{3}$ Council in Action, p. 172; Theologie im Aufbruch, p. 98 , emphasis is Küng's.

${ }^{4}$ This was not merely his position in 1962 (in Council in Action), but is still his view today (see Theologie im Aufbruch [1987], p. 98). 
towards the whole of the New Testament. "1 This catholic attitude is to be open "in every direction that the New Testament leaves open; not to exclude. . . any line that belongs to the New Testament." 2 In view of these statements, Küng's controversial interpretation of the biblical doctrines contrasts sharply--at first sight even queerly--wich his concept of heresy as a selection from the totality of revelation.

It must be noticed that Kung's holistic approach to the NT Canon cannot be explained as part of the pre-critical stage of his theological development. ${ }^{3}$ As early in 1962 and in the same essay which I just referred to, 4 he makes use of historical criticism. 5 He acknowledges the theological development found within the Canon, as well as the tenstons existing between its "earlier" and "later" documents or testimonies. ${ }^{6}$ Hence he sees no problem in explaining that in the Second Epistle of Peter we have not "one of the original

${ }^{1}$ Council in Action, p. 176.

2Ibid., p. 182; Theologie im Aufbruch, p. 102, emphasis in the orfiginal.

${ }^{3}$ For this particular matter, see above, chapter 2.

"Namely, "Early Catholicism," in Council in Action, PP. 159. 189. Cf. Theologie im Aufbruch, PP. 87-109.

5n fact, Küng stated that this very essay on "early Catholicism" was the first fruit of his use of the historical. critical principles of exegests "discovered" by him at Tübingen (see Haring and Kuschel, "Interview," p. 158).

${ }^{6}$ See, for instance, Counc11 in Action, PP. 180, 185-86. Among the earller strata of the NT, Kung quotes the Gospels of Mark and Matthew (see Eternal Life?, p. 243, n. 32). He alludes to the Gospel of John when referring to the later strata of the NT (ibid.). 
but one of the derived testimonies in the New Testament." 1 Yet, in defending the presence of "early Catholicism" already in the NT Canon (reflected in the practice of ordination, in the principle of succession, and in the leadership of office), Kung appeals precisely to such later documents as the Pastoral epistles and 2 Peter. The historical-critical approach to modern exegesis, with which he was at that time already well acquainted, did not preclude him from defending an all-inclusive understanding of the NT Canon. In this way, the conclusion which stems from the fact that in Küng's plea for early Catholicism in the NT the historical-critical study of the Siriptures and a holistic (non-selective) approach to the Canon did not prove incompatible, is that the teachings which one draws from the Scriptures seem not to depend principally on the exegetical procedure one uses, but rather on one's presuppositions and even on one's confessional bias. In Kung's particular case, the ecclesiological developments reflected in the "later layers" of the NT Canon do not clash with his conception of the structure of reality as, for instance, the Chistological developments in the same later layers do. Thus, Kung's presuppositions regarding the nature of reality seem to be the cause of his accepting the later ecclesiological developments while questioning similar developments in Christology. Thus, in answer to the question as to whether the use of the historical-critical methods of exegesis is "the cause" of our theologian's selectivity, as some have suggested, I submit that Küng's selectlvity would be indebted not to the historical-critical

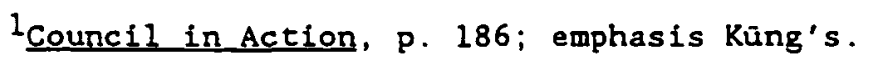


approach as such but rather to the presuppositions which constitute his hermeneutical criterion, namely, the contemporary scientifichistoricist world-view and, more specifically, his particular historicist view of reality.

The Important question which arises at this point is whether a sclentific criterion and a historicist world-view necessarlly would lead one to treat the biblical text selectively. Be that as it may, it seems appropriate as a means of avoiding subjectivity as much as possibie that one follow Küng's advise to take all the neotestamentarian lines serfously rather than making of the diversity existing in the NT an occasion for arbitrary and a priori selection.

In this context, a brlef consideration of Küng's dealing with the issue of the facticity of the Lord's resurrection may suffice to illustrate his application of the scientific-historicist hermeneutical criterion to the text of the Scriptures and to address the remaining questions raised above. This particular doctrine of the New Testament is retained here because the resurrection of the Messiah falis within the apocalyptic world-view which I address later.

Küng's contention that the resurrection of Jesus Christ "is not a historical eventil obviously cannot be held on the basis of the literal record of the New Testament. On the contrary, the testimony of the apostles in the canonical scriptures affirms the facticity of the resurrection (Matt 28:1-10; Mark 16:1-11; Luke

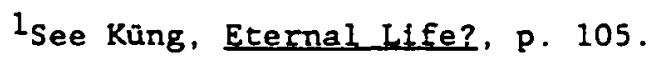


24:1-12; John 20:1-18). The four Gospels are careful to record the evidence of the empty tomb as well as the manifestation of the risen Lord to the disciples. According to the NT; the resurrection of Jesus Christ took place in space (his body disappeared from the tomb) and time (on the first day of the week). Kung's remark that the resurrection of the Lord did not happen "In space and time" but "bursts through and transcends the limits of history"l is the result, unquestionably, of the application of a specific hermeneutical criterion to the NT Canon. Still, the question as to the cause standing behind his application of the modern scientifichistoricist criterion to this particular doctrine must be asked.

The answer to this question seems to reside in kunng's understanding of the nature of reality. His conception of reality, which differs from that of the biblical writers, is indeed unveiled In his affirmation that Jesus Christ's resurrection, though "not a historical event" is still not merely "a fictitious but in the deepest sense a real event." 2 Explaining the difference between "historical" and "real," Küng remarks that even though the resurrection is not "a supernatural intervention that can be located and dated in space and time," 3 it is not either a merely imagined event but a real one in the deepest sense.

Two conclusions, at least, may be drawn from these statements. The first has to do with the particular conception of

I Ibid.

2 Ibid.

${ }^{3}$ Ibid. 
the structure of reality which küng seems to hold. Even though he otjects to the "two-tiers" model of the structure of reality, ${ }^{1}$ his historicist world-view is not one which assumes that history is the whole realm of being and that there is nothing besides or above spatio-temporal history. ${ }^{2}$ For Küng, a transcendent dimension does exist. True, he states that the resurrection means the "assumption into the absolutely final and absolutely first reality" which is neither "up there" or "over there," nor in an "outside" or "above" world, in the "beyond." 3 Nor is that reality "in our space or in our time,. . . 'here' and 'now' 'on this side'. ${ }^{4}$ Küng advocates a transcendence which differs from the conception of Plato, the Hellenists, and medieval men who located it in an extratemporal, suprahistorical, and static "upper deck." Transcendence is located by Küng, as it were, in an inner dimension, in the "innermost primal ground and primal meaning of world and man" which is the "ineffable mystery of our reality. "5 The transcendent, "meta-empirical" side of reality does not Ife "behind, beyond, above, outside" our

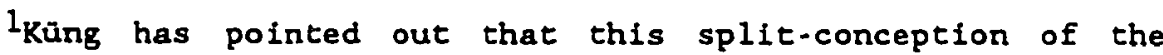
structure of reality started with the ontology of Plato and continued in its essential lines through Neo-Platonism and medieval Scholasticism down to the philosophy of Descartes and, more recently, that of the positivist Rudolf Carnap (see above, pp. 309. $315,323-335$ ). p. 18 .

${ }^{2}$ See Gillespie, Hegel. Heiddeger, and the Ground of History,

${ }^{3}$ Eternal Life?, pp. 113-14.

${ }^{4}$ Ibid., p. 113.

5Ibid., p. 114; emphasis Küng's.
} 
reality, but, "so to speak, constitutes the inner aspect of present reality." I In brief, Küng concelves the structure of reality in Hegelian terms as transcendence in immanence.

Another conclusion which may be drawn from Küng's interpretation of the NT account of Jesus' resurrection is that for him the resurrection of the Lord is a reality of faith, 1.e., "only for someone who is not a neutral observer, but who commits himself to it in reasonable trust." 2 The dialectical tension between history and faith characteristic of Küng's hermeneutics is obvious here. ${ }^{3}$ As with other doctrinal affirmations--the existence of God, for instance--our theologian's clinging to the reality of the resurrection must be counted as ultimately substantiated by faith alone.

In this way, we seem to have found an answer to the question as to the ratiosale for Kün's application of the scientifichistoricist criterion to the doctrine of the resurrection of Jesus Christ. It resides in his particular understanding of the structure of reality. Yet, it remains difficult to avoid the conclusion that an additional reason may also be identffied. In the issue of the resurrection, we are dealing with an event which the secular mind finds difficult to accept. In the words of Rudolf Bultmann, "an historical fact which involves a resurrection from the dead is utterly inconceivable. "4 Kung's concern for the proclamation of the

${ }^{1}$ Does God Existe?, p. 551.

2 Eternal Life?, p. 114.

${ }^{3}$ On this particular issue, see above, pp. 146-52.

"Bultmann, "New Testament and Mythology," in Hans Werner 
401

gospel in terms relevant and credible to the modern man finds an obstacle in "the incredibility of a mythical event like the resuscitation of a corpse-for that is what the resurrection means." 1 So, Küng deems it necessary to admit the unhistorical nature of the resurrection of Christ. The modern scientifichistorical horizon of understanding compels him to qualify the apostolic and scriptural testimony as orroneous in its iiteral terms. So stated, this verdict, to be sure, undermines the very fundament of the Christian faith as well as the integrity of the content of the gospel. Küng undoubtedly understands it so. It is here, then, that his remark that even though the resirrection is not localizable in space nor datable in time but is a "real event" acquires real importance.

Yet, Küng's interpretation of the biblical account of the Lord's resurrection, namely, his moving the reality of the resurrection from the spatio-temporal realm into an abstract dimension where the resurrection cannot be disproved nor confirmed, might sound to more than one skeptical child of our age as an attempt on Kung's part at avoiding to confront the possibility of an alleged forgery by the first disciples of Jesus. To be sure, Kung makes an effort to provide a cogent theory of the multi-dimensional nature of reality. Still, his solution to the problem of the facticity of the resurrection seems unable to totally preclude its

Bartsch, ed., Kerygma and Myth: A Theological Debate, 2 vols. (London: S.P.C.K., 1957), 1:39.

$I_{\text {Ibid. }}$ 
being counted as a double-track way of thinking involving history and faith, a solution which some may regard as aimed at achieving a peaceful coexistence of the biblical and the contemporary worldviews.

This observation strikes one as particularly relevant when it is recalled that küng criticizes Descartes precisely on this point. ${ }^{1}$ Küng questions the French philosopher's split-reality model ${ }^{2}$ and with it the rationalistic tendency to separate the spatial existence of things from the abstract realm of consciousness. A "distinction" between these two realms may be necessary and helpful, grants küng, but not an ontological and epistemological "separation." In his view, among the negative results of this "Cartesian dualism" or "disruption of reality" must be counted the "very questionable separation . . and double-tracking of thinking and faith, philosophy and theology, study and plety," etc. ${ }^{3}$ Hence, Küng commends Moltmann's observation that the cleavage existing in modern consclousness between theology and the natural sciences, that "two-track thinking of the modern mind," should be overcome by contemporary theology. ${ }^{4}$ As a specific example of this two-track ray of thinking, Küng quotes Rudolf Carnap's assertion that the "nonrational areas" of life where religious faith, intuition, feelings,

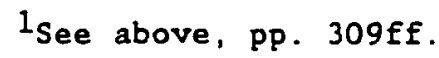

2 Does God Exist?, Pp. $26-29$.

${ }^{3}$ Ibid. , p. 29.

4Moltmann, Hope and Planning, pp. 201-204; see Küng, Does God Exist?, p. 125. 
and emotions belong, on the one hand, and science, on the other. "can neither confirm nor disprove one another." 1 In küng's words, this suggestion constituted Carnap's compromise for "peaceful coexistence" of the two very different fields. It was a form of "skeptical neutrality" which later turned to a "cold war" on the part of Carnap against metaphysical reality. 2

The question as to whether küng considers that he is treating the NT Canon selectively and thus falling in the same error as his Protestant colieagues might perhaps be addressed at this point. In the same way as the Protestant search for a canon within the Canon strikes one as arbitrary and selective from the perspecElve of a catholic hermeneutics, so from the perspective of the traditional revelational criterion it seems unavoidable to conclude that in the particular case of the resurrection of the Lord, Küng lefi un one side as a guantité negligeable such parts of the NT message which would not fit in his own new system. ${ }^{3}$ However, Küng's reinterpretation of the resurrection of Christ may be seen as consistent with his philosophical-theological presuppositions. He does not regard his approach as working dogmatically from established preconceptions but exegetically from the NT texts. ${ }^{4}$ In other

1Carnap, The Logical structure of the World, P. 293; quoted in Küng, Does God Exist?, p. 98.

2 Does God Exist?, p. 98 .

${ }^{3}$ I am using here Küng's own words of criticism toward the Roman Catholic interpretation of the Scriptures on the issue of the ecclesiastical office (see The Church, p. 530).

"I am using Küng's own words which, though written in another context, express in both contexts his same view (see The 
404

words, Küng might hold that he is letting the Scriptures to be their own interpreters, for he claims to be taking basically the historicist norm from the Bible itself rather than imposing on the Canon a norm external to it. In my opinion, that the historical understanding of being in contradistinction to the static Hellenistic conception is the basic assumption which belongs to the Scriptures may indeed be proved. What is debatable is that the particular historicist understanding of kung is the same as the biblical one.

In addition, it should be taken into consideration that küng has asserted that the ultimate norm of Christian truth, the one which must remain through all changes, is Christ himself and his gospel. I It is an essential part of Kün's concept of heresy that the latter is not to be condemned by reference to an orthodox system but by reference to the gospel. ${ }^{2}$ Heresy consists in questioning "the whole basic faith of the ecclesia $b_{y}$ presenting 'another gospel'," remarks he. ${ }^{3}$ From this perspective, it seems obvious that Kung can hardly regard his selectivity as heretical since it does not proclaim a new or different gospel. The key question which

Church, p. 41).

In one of his most recent publications, Küng asserts that in the Tubingen symposium of 1985 on the issue of the changes of paradigm in theology those who attended emphasized time and again that what must remain through all changes and needs to be interpreted afresh for our time is nothing else that the "old gospel" of Jesus Christ ("Ein neues Grundmodell von Theologie?," p. 212).

2The Church, p. 315.

${ }^{3}$ Ibid. 
needs to be raised now is: What does küng mean by "the gospel"? He has not said much on the subject beyond his identification of the gospel with the basic message of the forgiveness and salvation offered by God. In that way, the gospel may be considered as the center of Küng's personal falth. In order, however, to function as a concrete norm of Christian truth, the content of the gospel should be clearly defined, i.e., Küng should be able to indicate what zaactiy that concept includes and what it does not. Unless he does so, an evaluation of the gospel as his norma normans seems hardly possible .

All in all, it seems evident that the different interpretations of the Christian message which can be found among Christians, as well as the latter's discrepancies as to what is ultimately normative, are due to different sets of presuppositions which govern each one's judgment. In Küng's terms, those discrepancles are due to one's working within different paradigms. To an evaluation of his paradigm-change theory I now turn.

The Changes of Paradigm in Theology:

An Assessment

In the preceding section, I addressed the question of whether Küng considers that he is treating the NT Canon selectively and thus falling in the same error as his Protestant colleagues. In his view, does an inner inconsistency in his model of orthodoxyheresy really exist? That question was answered negatively. The answer is different, however, when the issue of selectivity is appreciated from a perspective different from Küng's, namely, from 
the standpoint of the tradition of the apostles and the church as well as from the perspective of the slassical revelational criterion.

The question was also asked whether Küng's selectlvity is due to the particular hermeneutical criterion of truth used by him, namely, the modern sclentifichistoricist criterion. It was mentioned in passing that this question could be answered affirmatively. I have also stated earlier in this chapter that the contemporary scientific-historicist world-view functions as Küng's decisive criterion of truth. Further consideration of the issue is addressed below. As to whether the use of the historical-critical methods of exegesis is the cause of Küng's selectivity, my answer was negative. His all-inclusive approach to the NT concerning the question of "early Catholicism" in spite of the historical-critical understanding of the composition of the Canon orsich he already had at that time, was regarded as tile test case in reaching tiris conclusion.

The remaining questions raised above are addressed in what follows. New questions are also raised, specifically regarding the applicability to the theological discipline of the paradigm-change theory elaborated by Thomas Kuhn in the context of the natural sciences. 1 More particularly, there is the question of the

InIs there such a thing as a new paradigm or basic model of theology?" This was the starting question at the International Ecumenical Symposium held in Tübingen in 1983 (see above, p. 342), where a group of theologians frcw different parts of the world dealt with the paradigm-theory as applied to theology. Küng presents a review of the main ideas held at this conference, which "was not without controversies," in the chapter "Ein neues Grundmodell von 
compatibility between Küng's dialectical understanding of how progress has been made in Christian theology and the model of Kuhn as to how progress is made in the natural sciences.

A review of both Kuhn's theory and Hans Küng's understanding of the interaction between two paradigms, should permit us to address the question as to the applicability of the paradigm-change theory to theology.

Thomas Kuhn's theory of the changes of paradigm in the natural sciences holds that a "crisis" in the generally accepted scientific model is usually at the origin of scientific "revolutions" and of a subsequent replacement of the old paradigm by a new one. ${ }^{1}$ At least three points must be underlined in this theory. (1) The transition to a new paradigm simply does not come about step by step; the process is not cumulative, as in "normal science," but "revolutionary." (2) The change of paradigm in science means "replacement," not dialectical synthesis. Commenting on Thomas Kuhn's paradigm-theory Hans Küng notes:

The established and the future paradigms are mutually incompatible: the old must yleid to the new. Now we can perceive what was behind both the case of Galileo and that of Darwin. Established and famillar concepts are changed. Norms and criteria are displaced. Theories and methods are shaken. . . The tctal world view is changed. ${ }^{2}$

Theologie?" which he contributed to the volume edited by himself and David Tracy, Das neue Paradiama von Theologie, pp. 205-216.

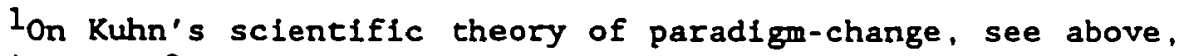
chapter 4, part 2 .

2 Does God Exist?, p. 108. 
In fact, Galileo's and Darwin's views unambiguously pointed to the error in the old paradigm which thus was to be definitely and completely rejected. (3) The crises which bring about the changes of paradigm are prompted by new discoveries in the scientific realm, more specifically, through the cumulative process of obtaining new data by the "normal science."

In reference to the third point, something similar occurs with the philosophical changes of paradigm. ${ }^{1}$ It must be noticed that in philosophy, as could be expected, the revolutions which have prompted a change of paradigm have generally originated within the domain of philosophical reflection. What can be said of theology? Have the main theological revolutions been caused by theological reflection? In most of the cases, this is not so. The crises which prompted theological revolutions have been brought about by either a new scientific or a new philosophical paradigm, which clearly expresses the lack of independence of the theological science. ${ }^{2}$ This was the case, for instance, for the new paradigms developed first by Clement and Origen, then by Augustine, and finally by Albertus Magnus and Thomas Aquinas. ${ }^{3}$ Their theological revolutions

InAre there 'scientific revolutions' in philosophy?," asks Küng. Calling one's attention to the turning points represented by Descartes and Kant, he answers positively (Does God Exist?, p. 111).

2In his doctoral dissertation Fernando Canale points out that, generally, theologians have accepted the results of a criticism of reason done within the philosophical realm as a ready-to-use package which, without further investigation or criticism, has been applied to the theological enterprise. See his "Toward a Criticism of Theological Reason: Time and Timelessness as Primordial Presuppositions" (Ph.D. dissertation, Andrews University, 1983), p. 6.

${ }^{3}$ These are the names suggested by Küng himself (see Does God 
were the result of the acceptance of the philosophical models of Hellenism, neo-Platonism, and Aristotle, respectively. Likewise, an extra-theological cause may be seen in the reaction of the Enlightenment and historical-critical theology to the Reformation. The latter, i.e., the paradigm of the Reformation, may well be the only macro-paradigm among those identified by küng which originated from a mostly iheological concern.

A review of Kung's understanding as to how two paradigms interact, might be helpful to answer the two questions related to the compatibility between his view and the theory of Kuhn. A consideration of Küng's position concerning the first paradigm of his own periodization of the history of the church and theology seems aderuate to this purpose. Focusing our attention on this particular paradigm, 1.e., the "early Christian-apocalypticai paradigm," not only enables us to deal with the paradigm which saw the birth of the documents of the NT-..which is of interest to me in the context of my evaluation of Küng's selective approach to the Canon. It will also make it possible to review the manner in which Kung sees the biblical and the Hellenistic paradigms to have interreacted, a topic on which he has written extensively, as we saw earlier in this dissertation. 1

In my opinion, Küng's denomination of the biblical paradigm as "apocalyptical" is most appropriate. Not only does it point to

Exist?, p. 111).

In connection with the modern understanding of the historiclty and secularity of God (see above, pp. 318-35). 
the escilictological-apocalyptical perception rather widespread among Christians in the first century A.D., but also it expresses the revelational ("apocalyptic") crfterion of truth which this dissertation has identified as predominant at that time.

There is little doubt, Indeed, that the eschatologicaiapocalyptic expectancy of the neotestamentarian church constituted one of lts characteristic traits. John Macquarrie has eloquently observed that "If we are to believe the New Testament scholars," eschatology was "of major importance for the New Testament writers themselves." 1 Wolfhart Pasncaberg, for his part, remarks that the primitive Christian mission among the Gentiles made both the expectation of the end and the resurrection of the dead "part of lts mission kerygma ( 1 Thess 1:9ff.; Heb 6:2)."2 Macquarrie goes even farther than Pannenberg, asserting that "surely a partial explanation of the amazing energy of the early Christian community is to be sought in its intense conviction of the approaching end." 3

Küng's designation of the first paradign of the history of the Christian church as "early Christian-apocalyptic paradigm"4

IJohn Macquarrie, "Eschatology and Time," in Jürgen Moltmann et al., The Future of Hope: Theolory as Eschatology, ed. Frederick Herzog (New York: Herder and Herder, 1970), p. 114. In fact, eschatology is so prominent in most of the NT writings, notes Macquarrie, that "any alleged interpretation which simply omitted it would hardly be a valid interpretation" (ibid., p. 119).

${ }^{2}$ Wolfhart Pannenberg, "Dogmatic Theses on the Doctrine of Revelation," in Revelation as History, ed. Wolfhart Pannenberg et al. trans. David Granskou (New York: Macmillan Company; London: Collier-Macmillan, 1968), p. 147.

${ }^{3}$ Macquarrie, "Eschatology and Time," P. 115.

${ }^{4}$ See above, pp. 349-50. 
411

likewise underlines the fact that the apocalyptical-eschatological expectation recorded in the NT was no side issue but a central locus of the theology, life, and mission of the early church. The validity of his assertion that this expectation is no longer central to the experience of today's man can only be recognized.

Coming closer to the issue of the definition of doctrinal truth and error, Küng evaluates the eschatological-apocalyptical expectation of an Imminent coming of God's kingdom as a mistaken bellef belonging to an obsolete paradigm. 1 He observes that some specific beliefs which were acceptable within the horizon of apocalyptic ideas have been superseded by modern developments in the "completely changed horizon of understanding of humanity today." 2 As we saw earlier, ${ }^{3}$ among these bellefs is the expectation of the imminent coming of God's kingdom. "We no longer live in imminent expectation of the end of the world," observes Küng. ${ }^{4}$ He also notes that the apocalyptic expectation of the kingdom of God in the immediate future--which "was mistaken"--is "too well documented in the earliest strata of the synoptic tradition to be disputed." 5 Because of "the scandal" of this mistaken and frustrated hope, "It

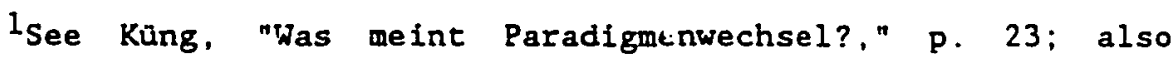
Eternal Life?, pp. 89-92.

2 Eternal Life?, p. 92.

${ }^{3}$ See above, p. 386

${ }^{4}$ Küng et al., World Relfieions, p. 30; emphasis is Küng's. That the end of the world will eventually come can be held also on the basis of current scientific theories, observes Kung (Eternal Iffe?, pp. 206-07).

${ }^{5}$ Eternal Life?. p. 92. 
was softened down in the later writings and strata of the New Testament. " 1

In view of these considerations, it seems obvious that küng would not regard a factual irruption of God's kingdom "from above" and a literal return of Christ as necessary to fulfill the promise of the Lord. These supernatural events are indeed hardly possible in his conception of reality. In fact, Küng submits that "the apocaiyptic horizon cannot and should not be artificially resuscitated today. ${ }^{2}$ In his view, the apocalyptic framework of imagery and understanding of the NT times, "now alien to us," would only "conceal and distort what was meant" and would "rouse false expectations for the Immediate present." 3 Küng's exegesis of the eschatological preaching of Jesus tries to recover what the Lord really meant; indeed, not what he said, but the "extremely urgent matter" with which he was concerned in his preaching of the advent of God's kingdom. ${ }^{4}$ What one reads between lines, teyond the actual words of Jesus or of the biblical writers, is, of course, open to

$1_{\text {Ibid. }}$

2 Ibid.

3Ibid. At this point, Pannenberg's concern might well be taken into consideration. He calls upon those who no longer live in the expectation of the end of the world, pointing out that "the church is always tempted to play down the still-impending future of the eschatological life and to forget that all forms of Christian life in this world are provisional" (Pannenberg, "Dogmatic Theses," p. 144). Acroracing joci a Biscoricai resurrection ó cinstst and a future-oriented eschatology, Pannenberg belleves that "the end of the world will be on a cosmic scale what has already happened in Jesus" (ibid., p. 142).

${ }^{4}$ Eternal Life?, p. 92 ; emphasis in the original. 
debate. Indeed, it seems that the problem of the interpretation of the biblical text is at the core of the majority of the controversies that occurred throughout the history of Christian theology. In past senturias, however, this hermeneutical dimension of the orthodoxy-hereg; satithesis does not seem to have existed at a conscious level. In fact, till the time of the Protestant Reformation the controversies of doctrine were mostly viewed in the context of the tension existing between the original deposit of faith and the teachings either of the church or of a particular theologian. In other words, those controversies were restricted to the object and the subject of theological knowledge, respectively. In modern times a shift has occurred which emphasizes the hermeneutical criterion--i.e., the interpretative factor of knowledge--as the locus where the orthndoxy-heresy entithesis is to be addressed.

Returning to the case of Küng, this results in making it increasingly difficult to question whether his way of interpreting the Scriptures is determined by the current world-picture. The latter functions as his criterion and norm of truth, though he affirms that his ultimate criterion and norm is Christ and his gospel. 1 In what concerns specifically the apocalyptic preaching of Christ and the tension existing in the NT between what some label the "realized eschatology" of John and the "future-oriented eschatology"n of the synoptic Gospels, Küng's refnterpretation is grounded

II have suggested that the gospel must be regarded as the center of Küng's personal faith rather than a concrete norm of orthodoxy (legitimate Christian belief and teaching).

2 The term "future-oriented" eschatology is used by John 
on the current world-view to which the apocalyptic-eschatological

beliefs seem so strange.

From the perspective of a catholic (holistic) interpretation of the NT, the question might still be asked, however: How can one today question the validity of the apocalyptical-eschatological hope without being exposed to the charge of reading the NT selectively? Küng's answer, I assume, would be that he is not arbitrarily selecting from the NT Canon, nor arbitrarily choosing a canon within the Canon, but approaching the latter as it should be approached when appreciated from the standpoint of a contemporary paradigm. This is readily acknowledged. The fact remains, however, that arbitrarily or not, he rejects a "catholic" approach to the Canon, and thus no longer regards it as canon. In other words, the content of the New Testament documents taken as one body no longer constitute the ultimate norm in his search for Chrisian truth. Still, Küng's selective approach to the NT Canon is not to be confounded with the hermeneutical approach sdopted by such Protestants as Luther and Kasemann, who look for a canon within the Canon. Küng's hermeneutical criterion is to be found in the horizon

\footnotetext{
Macquarrie to describe Moltmann's understanding of the end in "historical terms" in contrast with Rudolf Bultmann's "demythologized eschatology" which tries to bring eschatology into the present, "Into the here and now of our actual existence" (see Macquarrie, "Eschatology and Time," pp. 118, 120). Moltmann's position is presented in his volume Theology of Hope: On the Ground and the Imolications of a Christian Eschatology (New York and Evanston: Harper \& Row, Publishers, 1967). Moltmann holds that Christian expectation is directed to "something that has not yet happened so far," namely, "the fulfilmest of the resurrection of the dead that is promised in his [Jesus] resurrection, the fulfilment of the lordship of the crucified one over all things that is promised in his exaltation" (Theology of Hope, p. 228).
} 
of understanding of his own contemporaries. In a sense, then, he is not doing too differently from the apologists of the early church who struggled to present the gospel to their contemporaries within the horizon of understanding relevant to them, and, in that case, shaped by the categorles of the Hellenistic paradigm.

In sum, it must be concluded that for Küng, the replacement of the apocalyptic imagery and framework of understanding by the Hellenistic world-view made the early Christian paradigm to become obsolete toward the second or third centuries A.D. At the same Elme, the current world-view rejects any apocalypticism. However, we have seen that küng also objects to the hellenization of Christfan theology as a deformation of the biblical understanding of God. God's historical dynamism as well as His involvement in the affairs of the human world are seen by küng, in my opinion correctly, as belonging to the very essence of Scriptural conceptuality. This means, and it is of more than passing significance, that in Küng's eyes not everything which belongs to the second paradigm (the Hellenistic) constitutes an advance in theological knowledge. On the contrary, something which in his understanding belongs to the old paradigm (the early-Christian), namely, the historical conception of reality, deserves to be deemed as superior to the two-tier conception of the later Hellenistic paradigm. The question which one seems entitled to ask at this point is why küng extols the historicism of the apocalyptic-eschatological paradigm while rejecting the eschatological expectancy and the belief in the historical resurrection of Christ belonging to the same paradigm. 
Whatever the answer to this question may be, the fact is that this ambigulty suggests that the manner in which progress is made in theology differs from the way in which progress is made in the natural sciences, where the new paradigm simply supersedes the whole world picture of the old one.

We seer ta be in condition to answer the two questions raised earlier: whether the scientific paradigm-theory is apolicab!s. to theology and whether Küng's dialectical understanding of theological progress is compatible with his recenty adopted paradigm-change theory. The answer to the first question is a "yes" and "no." There is a certain correspondence indeed between the natural sciences and theology, especially as far as the revolutionary changes in one's world-view are concerned. Indeed, it can hardly be questioned that at specific points throughout history there have been "drastical," "epochal," and "far-reaching changes"l in the over-all constellation of beliefs and basic assumptions shared by the members of both the scientific and the theological communities. However, the fundamental difference which I have pointed out above, suggests that the application of the paradigmtheory to the history of theology canuot be made without some qualifications.

The second question still remains to be answered, namely, that which refers to the compatibility between Küng's dialectical understanding of theological progress and the paradigm-change theory. In the review of Kuhn's scientific theory and of Kün's

1see Küng, "Ein neues Grundmode11," p. 207. 
understanding of the interaction between the early Christian and the Hellenistic paradigms, one point has become clear: In the scientific paradigm-theory the relation between paradigms is one of replacement $^{1}$ of the old by the new. "The established and the future paradigms are mutually incompatible: the old must yield to the new," noted Küng. 2 Conversely, in Küng's model of theological change, as it was seen at work in the case of the biblical and the Hellenistic paradigms and particularly in what concerns their understanding of God, the realationship between paradigms is one of dialectical synthesis: Küng proposes that today's understanding of God should revert neither into "primitive anthropomorphic biblicism" nor into an "abstract Hellenism." 3 The relatively recent adoption by Küng of the paradigm-change model of theological progress thus seems to clash with his formerly adopted dialectical model.

\section{An Evalustion of Küng's Mose Relevant Contributions to the Understanding of Orthodoxy-Heresy}

Even though some of the Swiss theologian's views on the elements which constitute the structure of the orthodoxy-heresy dntithesis are not without certain problems, I must remark here that as a Christian believer and a theologian, I have personally learned much from Hans küng. Indeed, I am far from being alone in acknowledging his remarkable qualities. Küng's passion for truth as

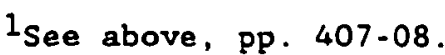

2 Does God Exist?, p. 108.

3Menschwerdung, p. 556. See my analysis above, pp. 323-35. 
well as his clarity of expression have been highly praised. ${ }^{1}$ Admiration has likewise been expressed regarding his multiple talents which make of him at the same time "a theologian and a scholar, a pastoral worker and a writer, a preacher and a professor, a priest and a controversialist, a Catholic and an ecumenist." 2 With rare ability he writes about issues which have almost everyone's interest. ${ }^{3}$ His amazing handing of information belonging to the fields of numerous disciplines in the humanities as well as in science also deserves commendation. His prolific literary production is second to none. His concern for preserving Christian unity is deeply moving. His intent to remain a Roman Catholic in spite of his official dismissal as a trustworthy Catholic theologian is to be admired, especially when In contemporary Christianity one can count no few examples of dissenters who turn schismatics. And the list could be enlarged.

Several of Küng's views deserve speclal commendation here. I have appreciated the insistence with which he underlines the normative priority of the biblical Canon over sub-apostolical ecclesiastics! szadtion. Not surprising, some will say, given the fact that my personal Christian heritage stems from the Protestant Reformation. Yet, one cannot overlook the fact that even within Protestant circles ecclesiastical tradition may tend indeed to supersede the ultimate authority of the Scriptures.

\footnotetext{
${ }^{1}$ So, for instance, Nowe11, A Passion for Truth, p. 16.

$2_{\text {Hăring and Kuschel, W\&W, p. } 8 .}$

${ }^{3}$ Kiwiet, Hans Küng, p. 147.
} 
Likewise, I highly value Küng's warning in the sense that Protestants seem to handle the biblical information in a one-sided fashion. His hermeneutical catholic (holistic) approach to the Canon, as well as his eagerness to accept it as one body in all its diversity is of invaluable significance if one wants to avoid the selectivity which küng deems typical of heresy. In this context, his remarks concerning catholicity and the role of the church in the transmission of the Christian faith, including the formation of the Canon, have enlightened my own theological reflection.

The same is true of Kung's preoccupation with the proclamation of the gospel in today's world in a relevant and meaningful way. In this respect, one can hardly deny the responsibility of the Christian believer of famfllarizing him or herself with the concerns and standpoints of those who do not share her or his Christian falth. At the same time, a critical examination of one's traditional beliefs should be counted among the moral duties of all Christians. We should not belleve juzt because others do it. Nor should we doubt simply because many do so. While unremittingly accepting the teacinings of Scrlptures as the word of God, an honest, methodical, and serious examination of the sources of Christian doctrine may indeed prevent faith from turning into superstition.

The most solemn attention should also be paid, in my opinior., to Küng's plea for an honest search for growing in the church's apprehension of Christian truth. This plea has a bearing not only on one's concept of truth but on one's understanding of the principle of religious authority as well. Indeed nobody who is in a 
position of ecclesiastical power (and there is "theological" power in the church besides administrative power) may claim to be free of the temptation of manipulating truth. Küng does well in reminding us that in the Christian church no "ruling party 'possesses' all truth, ${ }^{1}$ and that for the sake of Christian truth any repressing the possibility of free discussion of doctrinal issues in a Christian spirit should be avoided. In this connection, two insights of küng regarding the nature of truth seem most appropriate. First. since it is not always easy "to distinguish absolutely between truth and error." 2 and because heresies always draw their strength from part of the truth, ${ }^{3}$ the church would do well in listening to the concerns and demands of heretics and act accordingly after wessuring their concerns in the light of the original witness to the gospel of Christ. Second, in vlew of the fact that God alone is a priori infallible, 4 the church should not take the position that all its expositions of the content of revelation are without error. Not even the fact that certain teachings have been held as truth in the church for many centuries constitutes a proof that they are necessartly sorrect. In the words of Ellen G. White, "Age will not make error into truth."5 Hence, the church ought to be open to the

$1_{\text {Truthfulness, }}$ p. 142.

2 The Church, p. 332 .

$3^{3}$ Ibid. , pp. $318-19$.

${ }^{4}$ Infallible?, p. 219.

SEllen G. White, "Christ Our Hope," Review and Herald 69 (1892): 785 . 
possibility of continuously growing in its apprehension of the revealed truth, which implies that at times some views will have to be forsaken.

My Adventist understanding of the way in which the church defines the content of its doctrines leads me to express a word of appreciation for Küng's regard toward the consensus fidelium. 1 According to the testimony of the New Testament, Küng notes, it is not some individuals in the church but the whole community of faith that has the decisive word to say in mattars of doctrine. ${ }^{2}$ This means that no particular individual or group within the church should be regarded as holding ultimate authority to define the church's understanding of the suths of reveiacion. That is the task of the assembled community.

\section{Einal Considerations}

It secms appropriate to conclude this study with some observaticns addressed first to Hans Küng and then to those who will continue to show interest in the general question of truth and error In Christian doctrine, which was defined in the "Introduction" as the very issue undergirding the orthodoxy-heresy antithesis. ${ }^{3}$

As far as Küng's model of orthodoxy-heresy is concerned, this dissertation sheds light on the fact that his decisive norm of Christian truth falls within the realm of the modern scientific-

\footnotetext{
${ }^{1}$ see above, pp. $82-83$.

2 See above, pp. 234-35.

${ }^{3}$ See above, p. 2 .
} 
historicist horizon of understanding. Essentially, in his confrontation with the Roman Catholic Magisterium and in his dealing with the NT Canon Küng has proposed a new hermeneutical criterion for today's interpretation of the Christian tradition--a criterion which relies on the world-view of contemporary man. Instead of the apocalyptic conception of history presented in the Bible, and in place of the two-tier conception of the structure of reality supported by traditional Roman Catholicism, Küng advocates what might be labeled a "transcendence-in-immanence" historicist conception of reality. Thus, he judges the basic principles of classical orthodoxy, i.e., revelation and tradition, from the standpoint of a contemporary scientific-historicist perspective. In that context, kung has called the attention of the church to the human factor present in its proclamation of the Christian message. In his eyes, that factor affects not merely the continuity of the Christian message (tradition) but its origin as well (revelation). Specifically, Küng notes that there is no revelation outside of human experience. 1 This insight is as valid as it is helpful for the work of theological reflection. However, since revelation is not only central to the Christian faith but has a fundamental bearing upon the definition of Christian orthodoxy and heresy, one would like to see a more extensive elaboration on Küng's part upon the doctrine of revelation. This is particularly true regarding. the process whereby God manifests himself to the human mind so as to $1_{\text {See }}$ New Consensus, " p. 5. 
convey a clear portralt of himself and to deliver a clear message of guidance.

The complexity of this task must be readily acknowledged, especially at a time when the concept of revelation as a permanently valid body of truths communicated by God in biblical times and preserved by the church is widely questioned. The predicament of all contemporary Christians is well expressed by Carl E. Braaten:

Roman Catholic tileology today is catching up with Protestant theology; it is ni longer sure of what it means by revelation. Ever since the decline of Protestant orthodoxy, theology has been in search of a category by which to define revelation. The search continues today. 1

Other problems remain which also might require greater attention on the part of ysing. While there is no attempt here to ennumerate them, the mention of those which seem most comprehensive and relevant may help our theologian to further clarify the expression of his views. One of these issues is related to the paradigm-change theory. We noticed a fundamental difference between the "replacement model" of paradigm-change in the natural sciences and the manner in which progress is made in theology. 2 This observation suggests that as küng continues working with tine Raradianenwechsel theory, the difference just mentioned should be the object of careful attention.

Closely related to the latter is an issue which seems to
require clarffication. It concerns the inner consistency of Kung's

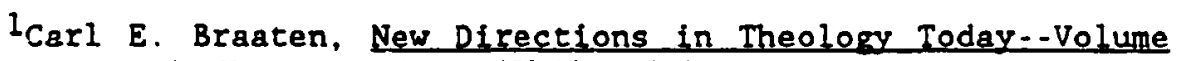
II: History and Hermeneutics (Philadelphia: Westminster Press, 1966), P. 11.

${ }^{2}$ See above, pp. $402-12$. 
own system as to how progress is made in theology. An inner tension between Küng's adoption of the paradigm.change theory (which postulates the mutual incompatibility of different paradigms and the replacement of the obsolete) and his formerly adopted dialectical model of theological development was pointed out a few pages ago. 1 As küng himself remarked recently, the work of studying the paradigm-theory in the context of christian theology is just beginning and it must become more precise. ${ }^{2}$ One does indeed wish that this inner tension be addressed by the Swiss theologian with greater theological precision.

It is precisely in the area of the paradigm-change theory that those who will continue studying the theology of Hans kung may find a fruitful field for investgation, especially in view of his observation that it will not be until this theory is fully applied to the intra-Christian and inter-religious ecumenical movements that its true flluminating power will be seen. ${ }^{3}$ The issue is all the more relevant for his theology since he has also announced his plan of writing a systematic theology in the context of the world's religions. 4

Let us now turn, beyond kung, to the very issue of orthodoxy-heresy in the general experience of the Christian church. 215-16.

$1_{\text {See above, p. } 413 .}$

2Küng, "Ein neues Grundmodell von Theologie?" (1986), pp.

${ }^{3}$ Ibid. . p. 216.

4nOn Being a Christian Theologian" (1987), p. 15. 
Although it is beyond the scope of the presant dissertation to occupy itself with a constructive proposal as to the question of orthodoxy-heresy as such, my analysis of Küng's approach to the issue and of his dealing with the components of the orthodoxy-heresy structure has led me to suggest several areas worthy of further investigation as well as a possible approach for dealing with the issue.

To begin with, the orthodoxy-heresy antithesis has, in many circles, retained much of its relevancy and can hardly be ignored. 1 It will remain a relevant issue, it seems, as long as there are dissenters and church authoricies opposing them, each side being convinced of the rightness of its own position and the wrongness of the other.

\begin{abstract}
Furthermore, Küng's experfence shows that even those who advocate pluralism uver unfformity, and ecumenism in place oz a spirit of controversy, cannot help being denunclatory and adversative when their own convictions are at stake. It appears that the categorles of orthodoxy and heresy, in their basic sense of the doctrinal truth-error antithests, will be obsolete only when doctrinal indifferentism wil be characteristic of most Christians.
\end{abstract}

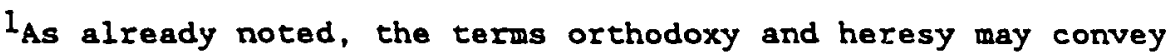
more than one meaning (see above, pp. 5-8). This study is not primarily interested in orthodoxy and heresy as understood in the historical terms of approved and condemned teachings. It is concerned, rather, with the theological issue of defining true and false teachings; namely, with the question of "truth" which is the concern of the believers when they are engaged in the dynamics of defining legitimate Christian teaching. 
In this context, it seems pertinent to raise the question as to the future state of the antithesis in matters doctrinal. Along which lines should the antithesis be addressed? Our study of two thousand years of church history suggests that we cannot return to the state of affairs of the period of the Protestant Reformation, when the tension between the Scriptures and tradition was brought into an impasse. 1 At that time, an ecclesiastical criterion of orthodoxy with its related norms could not evade the questions posed by the Reformers. Nor could the s:: slational criterion and the original norms of orthodoxy in which the criterion found expression solve all problems by themselves. Mis dissertarion points to the fact that it was only in modern times that the hermeneutical factor of knowledge came expiicitly to man's consciousness for the first time. Consequently, in the context of the doctrinal cuntroversies within Christianity, the discussions were not consciously moved into the hermeneutical level until very recently.

In view of this development, it seems appropriate to suggest here that the hermeneutical factor of theological knowledge must still be regarded as the locus when the orthodoxy-heresy antithesis is addressed in the future. However, scme questions remain. One of them is whether a scientific-historicist hermeneutical approach must necessarily lead one to treat the theological views of the NT selectively as kung does. It would be beneficial if a serious study could be made of this question. It would require consideration of, $200-215$.

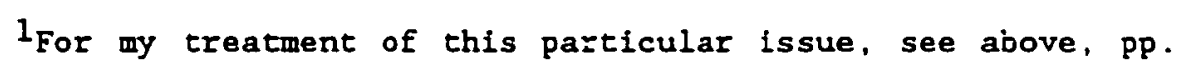




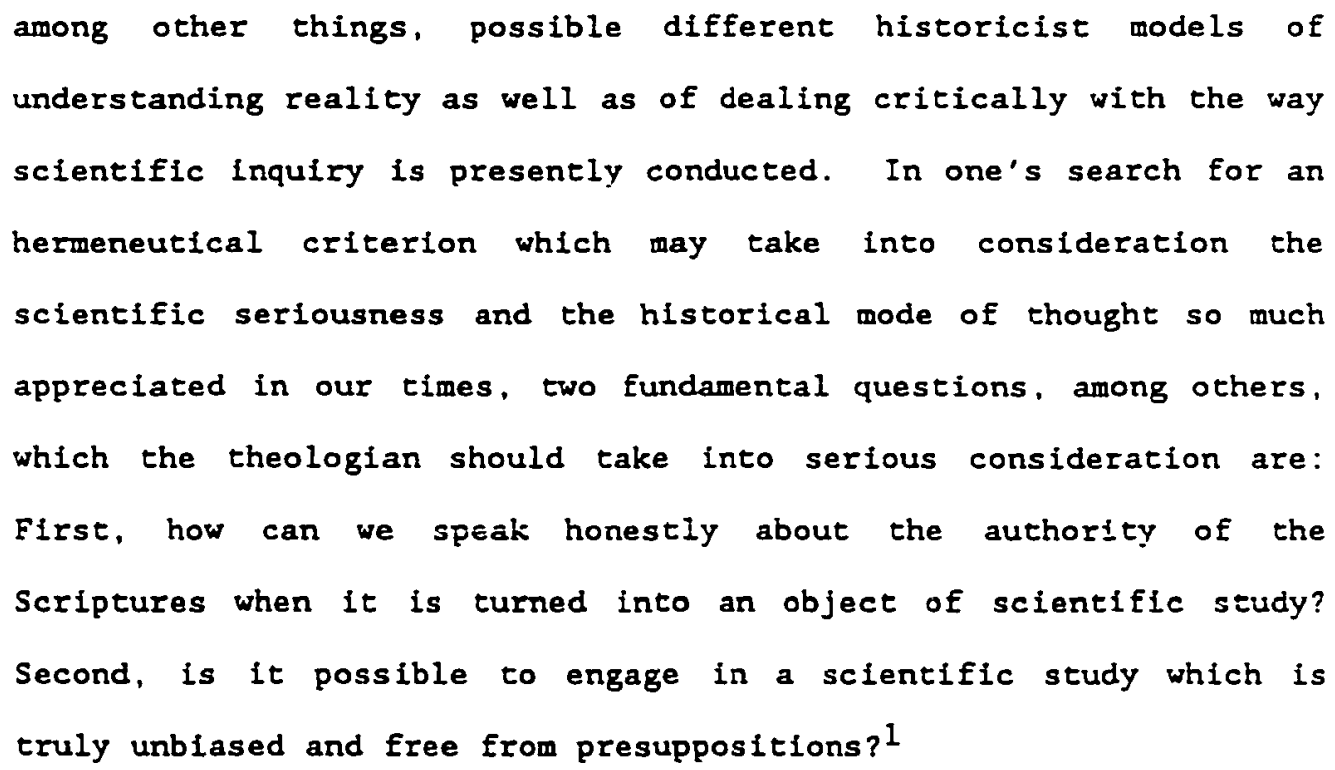

Along the same lines, another question which Christian theologians must ask themselves is whether a theological reflection more independent of philosophical and scientific presuppositions should not be seriously considered. 2 At first sight this may very well seem to be at odds with Küng's proposal of an intentionally sought, closer relationship between theology and other disciplines. ${ }^{3}$ What is suggested here is not that such a relationship be avoided,

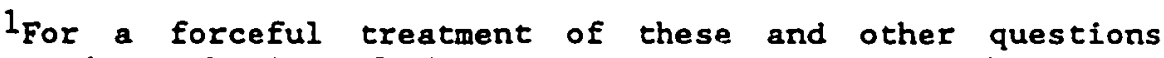
related to the authority of the Scriptures, see G. C. Berkouwer, $\underline{A}$ Half Century of Theology: Movements and Motives (Grand Rapids, Bilchlgan: Wililam B. Eerdmans Publishing Co., 1977), pp. 107-43, and passim. See also Raymond E. Brown, Blblical Exegesis and Church Doctrine; and Braaten, New Directions in Theology Today, pp. 33-52.

${ }^{2}$ See my discussion above, pp. 404-05. For instance, Canale has suggested the possibility of an independent theological criticism of theological reason (Fernando Canale, A Criticism of Thenlogical Reason: Time and Timelessness as Primordial Presuppositions [Berrien Springs, Michigan: Andrews University Press, 1987]).

${ }^{3}$ See "New Consensus," pp. 13-14. 
but rather that in the relationship between theology, philosophy, and the natural sciences, the dependence of theology on the presuppositions provided by the other two be critically addressed. This would constitute a basic change from the trend of dependence of theology upon philosophical and scientific presuppositions identified in this study as persisting, mostly unnoticed for a long time, throughout the history of Christian theology to the present.

Under the leading of the Holy Spirit the church's understanding of its theological sources will continue to change, as they have throughout the centuries. Change and continuity in Christian theological thinking are not options but facts. The hallmark of all orthodoxy is its looking back at the original sources of the Christian falth. Theologians of coming generations will undoubtedly propose new hermeneutical models to address the truths which God has entrusted to the church through revelation. If they perform their task not simply for their own personal satisfaction or in the service of a particular audience but of the whole comminity of falth, they may rightly point the way toward a rich diversity which, like that found in the Scriptures is harmoniously unified by the faith in a gractous God who revealed Himself throughout history to the Patriarchs, to the people of ancient Israel, and in Jesus Christ. 


\section{SELECTED BIBLIOGRAPHY}

\section{Primary Sources}

Küng, Hans. Art and the Question of Meaning. Translated by Edward Quinn. New York: Crossroad, 1981.

- The Church. Garden City, New York: Image Books, 1976.

. The Church--Maintained in Truch. Translated by Edward

Quinn. New York: Vintage Books, 1982.

"The Council--End or Beginning?" The Comnonweal 81

$(1965): 631-637$.

- The Council in Action: Theological Reflections on the Second Vaftcan Council. Translated by Cecily Hastings. New York: Sheed and Ward, 1963.

. The Council. Reform, and Reunion. Translated by Cecily Hastings. New York: Sheed and Ward, 1961.

- Does God Exist? An Answer for Today. Translated by Edwared Quinn. Garden City, New York: Doubieday \& Co.. 1980.

- Etenal Iffe? Life After Death as a Medical Philosophical and Theological Problem. Translated by Edward Quinn. Garden City, New York: Image Books, 1985.

- "Father Küng's Reflections on the Council." Theology Digest 11 (1963):65.

, ed. Eehlbar? Eine Bilanz. Zurich, Einsiadeln, and Cologne: Benziger Verlag, 1973.

. Ereedom Today. Translated by Cecily Hastings. New York: Sheed and Ward, 1966.

- Freud and the Problem of God. Translated by Edward Quinn. New Haven: Yaie University Press, 1979.

"Der Frühkatholizismus im Neuen Testament als kontroverstheologisches Problem." Theologische Quartalschrift 142 $(1962): 385-424$. 
. Gott und das Leid. Einsiedeln, Zurich, and Cologne:

Benziger, 1967.

. Infallible? An Inquiny. Translated by Edward Quinn. New

York: Doubleday, 1971.

- Justification: The Doctrine of Karl Barth and a Catholic ReElection. Translated by Thomas Collins, Edmund E. Tolk, and David Granskou. Philadelphia: Westminster Press, iḡil.

. The Living Church: Reflections on the Second Vatican Council. Translated by Cecily Hastings. London and New York: Sheed and Ward, 1963.

. "Looking Back." In Hermann Haring and Karl-Josef Kuschel, eds. Hans küng: His Work and His Way, Pp. 51-54. Garden City, New York: Image Books, 1980.

- Menschwerdung Gottes, Eine Einfurung in Hegels theologisches Denken als Prolegomeno zu einer kunfeigen Christologie. Fribourg: Herder, 1970.

- "Ein neues Grundmodell von Theologie? Divergenzen und Konvergenzen." In Das neue Paradisma unn Theologie; Strukturen und Dimensfonen, pp. 205-216. Edited by Hans Küng and David Tracy. Zurich: Benziger Verlag; Gütersloh, West Germany: fütersloher Verlaghaus Gerd Mohn, 1986.

. On Being a Christian. Translated by Edward Quinn. New York: Wallaby Books, Simon \& Schuster, 1978.

"On Being a Onristian Theologian." Translated by Heinz R. Kuehn. The Critfe 41 (Summer 1987):11-16.

"A Short Balance-Sheet of the Debate on Infallibility." In Truth and Certainty. Edited by Edward Schillebeeckx and Bas van Iersel. New York: Herder and Herder, 1973.

. Sienposts for the Future. Garden City, New York: Doubleday \& Co., 1978.

Structures of the Church. Transiated by Salvator Attanasio. New York, Edinburgh, and Toronto: Thomas Nelson \& Sons, 1964.

. That the World May Believe. Translated by Cec? $-;$ Hastings. New York: Sheed and Ward, 1963.

. "Theologie auf dem Weg zu einem neuen Paradigma." In Entwirfe der Theologie, Pp. 181-207. Edited by Johannes B. Bauer. Graz, Vienna, and Cologne: Styria Verlag, 1985. 
. Theologie im Aufbruch: Eine okumenische Grundlegung.

Munich and Zurich: Piper Verlag, 1987.

"Toward a New Consensus in Catholic (and Ecumenical)

Theology." In Leonard Swidler, ed. , Consensus in Theology? A

Dialogue with Hans küng and Edward Schillebeeckx, pp. 1-17.

Philadelphia: Westminster Press, 1980.

Truthfulness: The Future of the Church. Translated by

Edward Quinn. New York: Sheed and Ward, 1968.

. Was in der Kirche bleiben mussi. Zurich: Benziger

Verlag. 1973.

. Why I Am Still a Chrisctian. Translated by David Smith et

al. Edited by E. C. Hughes. Nashville: Abingdon Press, 1987.

- Why Priests? A Proposal for a New Church Ministry.

Translated by Robert C. Collins. Garden City, New York:

Doubleday and Co., 1972.

Küng, Hans, and Moltmann, Jürgen, eds. The Right to Dissent.

Concilium 158. Edinburgh: T. \& T. Clark, 1982 .

Kürig, Hans, and Tracy, David, eds. Das neue Paradigme von

Theologie: Strukturen und Dimensionen. Zurich: Benziger Verlag; Gutersloh, West Germany: Gätersloher Verlaghaus Gerd Mohn, 1986.

Küng, Hans; van Ess, Josef; von Stietencron, Heinrich; and Bechert, Heinz. Christianity and the World Relletons: Paths of Dialogue with Islam. Hinduism, and Buddhism. Translated by Peter Heinegg. Garden City, New York: Doubleday \& Co., 1986.

Küng, Hans, to Enrique Espinosa. Letter, June 2, 1987. Adventist Herftage Center. James White Lfbrary. Andrews University. Berrien Springs, Michigan.

\section{Secondary Sources}

Baum, Gregory et al. The Infallibility Debate. Edited by John J. Kirvan. New York, Paramus, and Toronto: Paulist Press, 1971.

Buggert, William F. "The Christologies of Hans Küng and Karl Rahner: A Comparison and Evaluation of Their Mutual Compatibility." D.Th. dissertation, The Catholic University of America, 1978.

Butterworth, Robert. "Questions to Hans Küng." The Heythrop Journal 18 (1977):436-446. 
Carey, John J. "Hans Kin: ind Tübingen: Compromise and Aftermach." ChrCent 97 (1980):791-796.

Costanzo, Joseph F. The Historical Credibility of Hans Kung [Sic]. North Quincy, Massachusetts: Christapher Publishing House, 1979.

Duggan, G. H. Hans Küng and Reunion. Westminster, Maryland: Newman Press, 1964.

Dulles, Avery. "Hans Küng's Infallible? An Inquiry: A Symposium. I: The Theological Issues." Americe 124 (1971):427-428.

Ehrlich, Rudolf J. "Review of Konzil und Wiedervereinigung: Emeuerung als Ruf in die Efnheit, by Hans Küng." Scottish Journal of Theology 15 (1962):207-208.

Espinosa, Enrique, to Hans Küng. Letter, May 14, 1987. Adventist Heritage Center. James White Library. Andrews University. Berrien Springs, Michigan.

Fenton, Joseph Clifford. "The Council and Fathei Küng." The American Ecclesiastical Review 147 (1962):178-200.

Fitzer, Joseph. "Hegel and the Incarnation: A Response to Hans Küng." The Journal of Religion 52 (1972):240-267.

Garrett, James L. "Review of The Council, Reform, and Reunion." Review and Expositor 60 (1963):441-443.

Greinacher, Norbert, and Haag, Herbert, eds. Der Fall Küng: Eine Dokumentation. Munich: Piper Verlag, 1980.

Haring, Hermann, and Kuschel, Karl-Josef, eds. Hans Küng: His Work and His Way. Translated by Robert Nowell. Garden City. New York: Image Books, 1980.

Haring, Hermann, and Nolte, J. Diskussion um Hans Küng "Die Kirche". Fribourg: Herder Verlag, 1971.

Hayes, Vincent de Paul. "Review of That the World May Believe." America 108 (1963):446.

Hebblethwaite, Peter. The New Inquisition? The Case of Edward Schillebeeckx and Hans Küng. San Francisco: Harper \& Row, Publishers, 1980.

Hughes, John Jay. "Infallible? An Inquiry Considered." Theological Studies 32 (1971): 196.

Jens, Walter, ed. Um Nichts als die Wahrheit, Deutsche Bischofskonferenz contra Hans Küng--Eine Dokunentation. Munich: Piper Verlag. 1978. 
Keane, Thomas F. "Review of Strukturen der Kirche." Worldmission (Winter 1962-63):125.

King, James Mattison. "Hans Küng's Concept of Authority." Ph.D. dissertation, Southern Baptist Theological Seminary, 1981.

Kirvan, John J., ed. The Infallibility Debate. New York: Paulist Press, 1971.

Kiwlet, John. Makers of the Modern Theological Mind: Hans Küng. Waco, Texas: Word Books, 1985.

LaCugna, Catherine Mowry. "The Theological Methodology of Hans Küng." Ph.D. dissertation, Fordham University 1979.

- The Theological Methodology of Hans gung. Chico, Calıfornia: Scholars Press, 198?.

Lamb, Matthew L. "Review of On Being a Christian." Religious Studies Review 4 (1978):92-99.

Langton, F. E. P. S. "Rome and Reunion." The Church Ouarterly Review 163 (1962):392-393.

Laws, Ernst. Küng und das Glaubensbekenntnis der Kirche. Cologne: Verlag Wort und Werk, 1978.

Lindbeck, George A. "Hans Küng's Infallible? An Inquicy: A Symposium. III: A Protestant Perspective." America 124 (1971): $431-433$.

Mylonas, Efstathios Vasilios. "An Evaluation of Hans Küng's Contribution to the Debate on Papal Infallibility." Ph.D. dissertation, Boston University, 1985.

Nowe 11, Robert. A Passton for Truth: Hans Küng and His Theology. New York: Crossroad, 1981.

Pozzo, Guldo. Magistero e teologia in $H$. Küng e $P$ Schoonenberg: Droblemi e riflesstoni. Rome: Cltta Nouva Editrice, 1983.

Rahner, Karl. "A Critique of Hans Küng Concerning the Infallibility of Theological Propositions." Homiletical and Pastoral Review 71 (May 1971): 12 377 .

. "Kritik an Hans Küng." Stimmen der Zeit 186 (1970): 361-

, ed. Zum Problem Unfehlbarkeit. Antworten auf die Anfrage von Hans Küng. Fribourg: Herder, 1971. 
Redfern, Martin, ed. Theologians Today: Hans Küng. London and New York: Sheed and Ward, 1972.

Rlchardson, James Earl. The Küng-Rahner Debate over Infallibility. Pasadena, California: Fuller Theological Seminary, 1973.

Swldler, Leonard, ed. Consensus in Theology? A Dialogue with Hans Küng and Edward Schillebeeckx. Philadelphia: Westminster Press, 1980.

, ed. Küng in Conflict. Garden City, New York: Image Books, 1981.

United States Catholic Conference. The Küng Dialogue: A Documentation on the Efforts of the Consregation for the Doctrine of the Faith and of the Conference of German Bishops to Achieve an aporopriace clarification of the Concroversial Views of Dr. Hans Küng lTübingenl. Washington, D.C.: Publications Office of the U. S. Catholic Conference, 1980.

Von Balthasar, A. O. Diskussion wher Hans Küng's "Christ Sein." Mainz, West Germany: Matthias-Grunewald-Verlag, 1976.

\section{General Bibliography}

Abbott, Walter M., ed. The Documents of Vatican II: In a New and Definitive Translation with Commentaries and Notes by Catholic. Protestant and 2rthodox Authorfties. Translated by Joseph Gallagher. Introduction by Lawrence Cardinal Shehan. New York: Herder and Herder and Association Press, 1966.

Adler, Mortimer J. Aristotle for Everybody. New York: Macmillan Publishing Co., 1978.

Althaus, Paul. Die christliche Wahrheit, Lehrbuch der Dogmatik. Gutersloh: Gerd Mohn, 1969.

Anderson, Floyd, ed. Counctl Daybook: Vatican II (Sessions 1 through 4l. 3 vols. Washington, D.C.: National Catholic Welfare Conference, 1965-1966.

Aquinas, St. Thomas Summa Theologiae: Latin Text and English Translation. Introduction. Notes, Appendices and Glossaries, 60 vols. New York: McGraw-H111 Book Company; London: Eyre \& Spottiswoode, 1964.

Aristotle Metaphysics. Translated by W. D. Ross. Great Books of theWestern World. Vol. 8: The Works of Aristotle, Volume I. Edited by Robert Maynard Hutchins. Chicago, London, and Toronto: Encyclopaedia Britannica, 1952. 
Aubert, Roger. "Modernism." Sacramentum Mundi. 1969 ed. 4:99. 104.

Augustine, St. Soliloquiorum, liber secundus. J.-P. Migne, Patrologiae cursus completus. Series latina. 32:885-904.

- De vera religione. J.-P. Migne, Patrologiae cursus completus Series latina. 34:121-172.

Baillie, Donald M. The Idea of Revelarion in Recent Thought. Nes York: Columbia University Press, 1956.

Bainton, Roland $\mathrm{H}$. Concerning Heretics. New York: Columbia üniversity Press, 1935.

Baraúna, Guilherme and Congar, Yves M.-J., eds. L'Élise de Vatican II: Etudes autour de la Constitution conciliaire sur l'Église. 3 vols. Paris: Les Editions du Cerf, 1966-1967.

Barr, James. The Semantics of Biblical Language. Glasgow: Oxford University Press, 1961.

Bartsch, Hans-Werner, ed. Keryoma and Myth i A Theological Debate. 2 vols. London: S.P.C.K., 1962.

Bauer, Walter. Orthodoxy and Heresy in Earliest Christianity. Edited by Robert A. Kraft and Gerhard Krodel. Translated by a team from the Philadelphia Seminar on Christian Origins. Appendices by Georg Strecker. Philadelphia: Fortress Press, 1979.

- Rechtgläublakeit und Ketzeref im altesten Christentum. Tübingen: Mohr/Siebeck, 19?!.

Baum, Gregory. "Commentary." In "De Ecclesfa:" The Constitution on the Church of the Vatican council II, pp. 31-39. Edited by Edward H. Peters. Glen Rock, New Jersey: Paulfst Press, 1965.

Bäumer, Remigius. "Die Erforschung des Konstanzer Konzils." In Das Konsianzer Konzi1, pp. 3-34. Edited by Remigius Baumer. Darmstadt: Wissenschaftliche Buchgeselischaft, 1977.

Bayne, Jr., Stephen F. Theological Freedom and Social Responsibil1ty: Report of the Advisory Committee of the Episcopal Church. New York: The Seabury Press, 1967.

Bea, Augustin Cardinal. The Word of God and Mankind. Chicago: Franciscan Herald Press, 1967.

Beckwith, Clarence Augustine. "Orthodoxy and Heterodoxy." The New Schaff-Herzog Encyclopedia of Religlous Knowledge. $1910 \mathrm{ed}$. $8: 278-279$. 
Beegle, Dewey M. Scripture. Tradition, and Infallibility. Grand Rapids, Michigan: W. B. Eerdmans Publ. Co., 1973.

Berkouwer, G. C. A Half Century of Theology: Movements and Motives. Translated and edited by Lewis $B$. Suedes. Grand Rapids, Michigan: William B. Eerdmans Publ. Co., 1977. . The Second Vatican Council and the New Catholicism. Translated by Lewis B. Smedes. Grand Rapids, Michigan: Wm. B. Eerdmans Publ. Co., 1965.

Betz, Hans Dieter. "Orthodoxy and Heresy in Primitive ChristianIty. " Integpretation 19 (1965):299-311.

Bindley, T. Herbert, ed. Tertulliani. "Praescriptione Haereticorum ad Martyras: Ad Scapulamn. Oxford: At the Clarendon Press, 1893.

Bloesch, Donald G. Essentials of Evangelical Theology. Vo1. 1: God. Authority and Salvation. San Francisco: Harper and Row, Publishers, 1978.

Bolich, Gregory G. Authorlty and the Church. Washington, D.C.: University Press of America, 1982.

Boman, Thorleif. Hebrew Thought Compared with Greek. Translated by Jules L. Moreau. New York and London: W. W. Norton \& Co., 1970

Bosc, Jean et al. Roints de vue de théologiens protestants: Études sur les décrets du Conclle Vatican II, Unam Sanctam 64. Preface by Cardinal J.-M. Martin. Paris: Les Éditions du Cerf, 1967.

Braaten, Carl E., and Harrisville, Roy A., eds. Kerygma and Histery: A symposium on the Theoiogy of Rudolf Bultmann. New York and Nashville: Abingdon Press, 1962.

. New Directions in Theology Today--Volume II: History and Hermeneutics. Philadelphia: Westminster Press, 1966.

Brown, Harold. Heresies: The Image of Christ in the Mirror of Heresy and Orthodoxy from the Apostles to the Present. Garden City, New York: Doubleday \& Co., 2984.

Brown, Raymond E. Biblical Exegesis and Church Doctrine. New York and Mahwah: Paulist Press, 1985.

Brown, Robert McAfee. Observer in Rome: A Protestant Report on the Vatican Council. Garden City, New York: Doubleday \& Co., 1964.

Bruce, F. F. Tradition $01 d$ and New. Exeter: The Patermoster Press, 1970. 
Peter, Stephen. James, and John: Studies in Early NonPauline Christianity. Grand Rapids, Michigan: Wm. B. Eerdmans Publishing Co., 1980.

Brümmer, Vincent. Theology and Philosophical Inquify: in Introducfton. Philadelphla: Westminster Press, 1982.

Brunner, Emil. Revelation and Reason. Translated by olive Wyon. Philadelphia: Westminster Press, 1946.

Bryant, Robert $H$. The Bible's Authority Today. Minneapolis: Augsburg Publishing House, 1968.

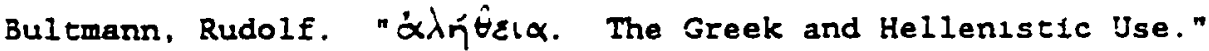
Theological Dictionary of the New Testament. Edited by Gerhard Kittel. Grand Rapids, Michigan: Wm. B. Eerdmans Publishing Co.. 1976. 1:238-251.

"New Testament and Mythology." In Hans Werner Bartsch,
ed. Keryema and Myth:A Theological Debate. 2 vols. London: S.P.C.K., 1957. 1:39.

- The Presence of Ecernicy: History and Eschatology. The G1fford Lectures 1955. New York: Harper \& Brothers, 1957.

. Theolegy of the New Testament. 2 vols. Translated by Kendrick Grobel. New York: Charles Scribner's Sons, 1955.

Burger, Karl. "Orthodoxy and Heterodoxy." The New Schaff-Herzog Encyclopedia of Religlous Knowledge. 1910 ed. 8:277-278.

Butler, Christopher, ed. The Vatican Counc11, 1869-1870: Based on Bishop U1lathorne's Letters. London: Collins and Harvill Press, 1962.

Campbe11, Dennis $M$. Authority and the Renewal of American Theology. Philadelphia: United Church Press, 1976.

Campenhausen, Hans F. von. Kirchliches Amt und geistliche Vollmacht in den ersten drei Jahrhunderten. Tübingen: Verlag J. C. B. Mohr, 1953.

- The Fathers of the Latin Church. Translated by Manfred Hoffmann. London: Adam \& Charles Black, 1964.

. The Formation of the Christian Bible. Translated by $J$. A. Baker. Philadelphia: Fortress Press, 1972.

Canale, Fernando. A Critictsm of Theological Reason: Iime and Timelessness as Primordial Presuppositions. Berrien Springs, Michigan: Andrews University Press, 1987. 
- "Toward a Criticism of Theological Reason: Time and Timelessness as Primordial Presuppositions." Ph.D. dissertation, Andrews University, 19:3.

Carnap, Rudolf. The Logical structure of the World \& Pseudoproblems in Phtlosophy. Translated by Rolf A. George. Berkeley and Los Angeles: University of California Press, 1967.

Casserley, J. V. Langmead. The Retreat from Christianity in the Modern World. London, New York, and Toronto: Longmans, Green and Co., 1953.

Catholic Bishops of the United States. The Church in Our Day: A Collective Pastoral of the American Hierarchy on the Mystery of the Church, on Her Nature and Function. Prepared in the Light of the Dosmatic Constitution on the Church Adopted by Vatican Councll II. Washington, D.C.: United States Cathollc Conference, 1968.

Cauthen, Kenneth. The Impact of American Relfolous Liberalism. New York and Evanston: Harper \& Row, Publishers, 1962.

Clement of Alexandria Stromata. The Ante-Nicene Fathers. Alexander Roberts and James Donaldson, eds. Grand Rapids, Michigan: Eerdmans, 1962. 2:299-567.

Colombo, Carlo. "The Hierarchical Structure of the Church." In Vatican II. An Interfaith Appraisal. Interna ional Theological Conference, University of Notre Dame: March 20-26, 1966 , pp. 208-218. Edited by John H. Miller. Notre Dame, Indiana: University of Notre Dame Fress, 1966.

Congar, Yves M.-J. Le Concile au jour le jour: trolsteme session. Paris: Les Éditions du Cerr, 1965.

. "A Semantic History of the Term Magisterium." In Beadings in Moral Theolory No, 3 . The Magisterium and Moralit: Pp. 297-313. Edited by Charles E. Curran and Richard A. McCormick. New York: Paulist Press, 1982.

"Towards a Catholic Synthesis." In Jurgen Moltmann and Hans küng, eds. Who Has the Say in the Church? Edinburgh: $T$. \& T. Clark; New York: Seabury Press, 1981.

- Vraie et fausse réforme dans 1'église. Paris: Éditions du Cerf, 1950.

Cornford, Francis MacDonald. Plato and Parmenides: Parmenides' "Way of Truth" and Plato's "Parmenides" Translated with an Introduction and a Running Commentary. London: Routledge \& Kegan Paul, 1939,1964 . 
Croce, Benedetto. La storla come pensiero e come azione. Bari:

Gius. Laterza \& figli, 1943.

C:IImann, Oscar. Christ and Time: The Primitive Christian

Conception of Time and History. Translated by Floyd V. Filson. Philadelphia: Westminster Press, 1950.

- The Early Ghurch: Studies in Eacly Christian History and Theolooy. Edited by A. J. B. Higgins. Translated by A. J. B. Higgins and S. Godman. Philadelphia: Westminster Press, 1956.

- Vaticair Council II. The New Direction. Edited by James D. Hester. New York, Evanston, and London: Harper \& Row, 1968.

Cuneo, Ernest. Sclence and History. New York: Duell, Sloan and Pearce, 1963.

Cinliffe-Jones, H. The Authority of the Biblical Revelation. London: James Clarke \& Co., 1945.

Cyprian De unitate ecclessiae. The Ante-Nicene Fathers. Alexander Roberts and James Donaldson, eds. Grand Rapids, Michigan: Eerdmans, 1957. 5:421-29.

. Eplstles. The Arte-Nicene Fathers. Alexander Roberts and James Donaldson, eds. Crand Rapids, Michigan: Eerdmans, 1957. 5:275-409.

D'Arcy, M. C. The Sense of History. Secular and Sacred. Westport, Connecticut: Greenwood Press, Publishers, 1959.

Davies, Rupeit $\Sigma$. The Problem of Authority in the Continencal Reformers. A Study in Luther 2 wingli, and Calvin. London: Epworth Press, 1946.

- Religious Authority in an Age of Doubt. London: Epworth Press, 1968.

De Vooght, Paul. Les pouvoirs du concile et l'autorité du pape au conctle de Constance: Le décret Haec Sancta Synodus du 6 avril 1415. Unam Sanctam 56. Paris: Les Editions du Cerf, 1965.

Denzinger, Henry. The Sources of Catholic Dogma. Translated by Roy $\mathrm{J}$. Deferrari from the 30th ed. of Denzinger's Enchiridion Symbolorum. Revised by Karl Rahner. Saint Louis: B. Herder Book Co., 1957.

Deutsch, Ellot. On Truth: An Ontological Theory. Honolulu: The University Press of Hawail, 1979.

DeWolf, L. Harold. The Case for Theology in Liberal Perspective. Philadelphia: Westminster Press, n.d. 
Dfem. Hermann, Dogmatics. Translated by Harola Knight. Philadelphia: Westminster Press, 1960.

Dietzfelbinger, Wolfgang. "The Council Continues: Third Session." In George A. Lindbeck, ed. Dialogue on the Way: Protestants Report from Rome on the Vatican Council, pp. 72-94. Minneapolis: Augsburg Publishing House, 1965.

Dodd, Charles H. The Authority of the Bible. New York: Harper and Row. 1929.

The Apostolic Preaching and Its Developments. New York and London: Harper \& Brothers Publishers, 1944.

"Dogma, Freedom, Change and Continuity." Herder Correspondence 5 (1968): 265-270.

Döllinger, Johann Joseph Ignaz von. Letters from Rome on the Council. London, Oxford, and Cambridge: Rivingtons, 1870.

Dominian, Jack. Authority. Huntington, Indiana: Our Sunday Visitor, 1976.

Dulles, Avery. "The Church." In The Documents of Vatican II, pp. 9-50. Edited by W. M. Abbott. New York: Herder and Herder. 1966.

- Models of Revelation. Garden City, New York: Image Books, 1985 .

"Successio apostolorum--Successio prophetarum--Success io doctorum." In Jürgen Moltmann and Hans Küng, eds. Who Has the Say in the Church? Edinburgh: T. \& T. Clark; New York: Seabury Press, 1981 .

- The Survival of Dogma. New York: Doubleday \& Co., 1971.

Dunn, James D. G. Untty and Diversity in the Ner: Testament: An Inquiry into the Character of Earliest Christianity. Philadelphia: Westminster Press, 1977.

Dvornik, F. "Photius, Patriarch of Constantinople." New Catholic Encyclopedia. 1967 ed. 11:326-29.

Ebeling, Gerhatd. Theology and Proclamation: Dialogue with Bultmann. Translated by John Riches. Philadelphia: Fortress Press, 1966.

Word and Faith. Translated by James W. Leitch. Philadel. phia: Fortress Press, 1963. 
441

Edward, Henry (Archbishop of Westminster). Vatican Council and Its Definitions: A Pastoral Letter to the Clergy. New York: D. \& J Sad1ier, 1871 .

Empie, Paul C., Murphy, T. A., and Burgess, J. A., eds. Teaching Authority \& Infallibility in the Church: Lutherans and Cacholics in Dialogue VI. Minneapolis: Augsburg Publishing House, 1980.

Eusebius Ecclesiastical History. Translated and Introduction by G. A. Williamson. Eusebius, The History of the Church from Christ to Constantine. New York: New York University Press, 1966.

Ewing, A. C. The Fundamental Questions of Philosophy. London: Routledge \& Kegan Paul, 1951.

Fangmeler, Jürgen and Stoevesandt, Heinrich, eds. Karl Barth-Letters 1961-1968. Translated by Geoffrey W. Bromiley. Grand Rapids, Michigan: William B. Eerdmans Publ. Co, 1981.

Farley, Edward. Ecclesial Man: a Sncia! Pheñumenulogy of Faith and reality. Philadelphia: Fortress Press, 1975.

Flannery, Austin, O. P. Vatican II on the Church. Dublin: Scepter Books, 1967.

Flew, Antony, ed. A Dictionaty of Philosophy. London: Pan Books and Macmillan Press, 1979.

Forsyth, P. T. The Principle of Authority in Relation te Cercalnty, Sanctity and Society. 2nd. ed. London: Independent Press, 1952 .

Franzen, August. "Das Konstanzer Konzil: Probleme, Aufgaben und Stand der Konzilsforschung." In Das Konstanzer Konzil., Pp. 165. 207. Edited by Remigius Baumer. Darmstadt, West Germany: Wissenschaftliche Buchgesellschaft, 1977.

Fremantle, Anne, ed. A Treasury of Early Christianity. New York: Viking PLess, 1953.

Fries, Heinrich and Finsterhölzl, Johann. "Infallibility." Sacramentum Mundi. 1969 ed. 3:132-138.

Gale, Richard M. "Propositions, Judgments, Sentences, and Statements." The Encyclopedia of Phliosophy. 1967 ed. 6:494-504.

Gallie, W. B. Philosophy and the Historical Understanding. New York: Schocken Books, 1968.

Ganoczy, Alexandre. Calvin et Vatican II: L'Église servante. Paris: Les Éditions du Cerf, 1968. 
Geldenhuys, J. Norval. Supreme Authority: The Authority of the Lord. His Apostles and the New Testament. Grand Rapids. Michigan: Wril. B. Eerdmans Publishing Co., 1953.

Gerhardsson, Birger. Tradition and Transmission in Early ChristianLEy. Lund, Sweden: C. W. K. Gleerup, 1964.

Gilles, Anthony E. The People of the Creed: The Story Behind the Early Church. N.P.: St. Anthony Messenger Press, 1985.

Gillesple, Michael Allen. Hezel Heidegrer, and the Ground of History. Chicago \& London: The University of Chicago Press. 1984.

Glorieux, Palémon. "Gerson (Jean)." Dictionnaire de spirltualité. Paris: Beauchesne, 1965. 6:314-331.

Grent, Robert M. The Formation of the New Testament. New York: Harper \& Row, Publishers, 1965.

ed. Gnosticism: A Source Book of Heretical Writings from the Early Goristian Period. New York: Harper \& Brothers, 1961.

Grootaers, Jan. Primauté et colléplalité: le dossier de Gérard Philips sur la Nota Explicativa Praevia (Lumen gentium, Chap, III). Preface by G. Thils. Louvain, Belgium: University Press, 1986.

Guthrle, W. K. C. A History of Greek Philosophy. 6 vols . Cambridge: At the University Press, 1962.

Harnack, Adolf von. History of Dogma. 7 vols. Translated by Neil Buchanan. New York: Dover Publications, 1961.

- The Origin of the New Testament and the Most Important Consequences of the New Creation. Translated by J. R. Wilkinson. New York: Macmillan Co., 1925.

Harrington, Daniel J. "The Reception of Walter Bauer's Orthodoxy and Heresy in Earliest Christianity During the Last Decade." Harvard Theological Review 73 (1980):289-298.

Hasler, August Bernhard. How the Pope Became Infallible: Pius IX and the Politics of Persuasion. Introduction by Hans Küng . Translated by Peter Heinegg. Garden Clty, New York: Doubleday \& Co. , 1981 .

Hatch, Edwin. The Influence of Greek Ideas and Usages upon the Christian Church: The Hibbert Lectures, 1888 . 2nd. ed. Edited by A. M. Fairbairn. London: Williams and Norgate, 1891. 
Hawthorne, Gerald F., ed. Current Issues in Biblical and Patristic interpretation. Grand Raplds, Michigan: William B. Eerdmans Publishing Co., 1975.

Hebblethwaite, Peter. The Council Fathers and Atheism: The Interventions at the Fourth Session of Vatican Council II. New York: Paulist Press Deus Books, 1967.

Hegel, Georg Wilhelm Friedrich. Lectures on the Philosophy of World History. Introduction: Reason in History. Translated by H. B. Nisbet. Introduction by Duncan Forbes. Cambridge: Cambridge University Press, 1975.

Hégy, Plerre. L'autorité dans le catholicisme contemporain, du Syllabus a Vatican II. Theologie historique 30 . Paris: Editions Beauchesne, 1975.

Heidegger, Martin. History of the Concept of Time: Proleromena. Translated by Theodore Kisiel. Bloomington, Indiana: Indiana University Press. 1985.

Heinemann, Heribert. "Heresy: Concept." Sacramentum Mundi. 1969 ed. $3: 16$.

Henry, Patrick. Schools of Thought in the Christian Iradition. Philadelphia: Fortress Press, 1984.

Hilgenfeld, Adolf. Die Ketzergeschichte des Urchristentums. Hildesheim, West Germany: Georg Olms Verlagsbuchbandlung, 1966.

Hippolytus Refutation of All Heresies. The Ante-Nicene Fathers. Alexander Roberts and James Donaldson, eds. Grand Rapids, Michigan: Eerdmans, 1957. 5:9-153.

Hollis, Christopher. The Achievements of Vacican II. Twentiech Century Encyclopedia of Catholicism, vol. 1. New York: Hawthorn Books, 1967.

Hordern, William E. Aayman's Guide to Protestant Theology. Rev. ed. New York: Macmillan Publishing Co., 1968.

Houtepen, Anton. "A Hundred Years after Vatican I: Some Light on the Concept of Infallibility." In Truth and Certainty. p. 119. Edited by Edward Schillebeeckx and Bas van Iersel. New York: Herder and Herder, 1973.

"How the Pope Made up His Mind." N.a. Herder Correspondence 5 (1968): $336-337$.

Hunter, Archibald Macbride. The Message of the New Testament. Philadelphia: Westminster Press, 1944. 
Irenaeus Adversus haereses. The Ante-Nicene Fathers. Alexander Roberts and James Donaldson, eds. Grand Rapids, Michigan: Eerdmans, 1956. 1:315-567.

- Demonstratio apostolicae praedicationis. Edited by Joseph P. Smith. St. Irenaeus, "Proof of the Apostolic Teaching Ancient Christian Writers. The Works of the Fathers in Translation, No. 16. New York: Newmar. Press, 1952.

James, William. The Meaning of Trurh: A Sequel to "Pragmatism". New York: Longmans, Green, and Co, 1909

Jedin, Hubert. "Conciliarism." Sacramentum Mundi. 1968 ed. $1: 401-402$.

- Ecumenical Councils of the Catholic Church: An Historical Qucline. Translated by Ernest Graf. Fribourg: Herder; Edinburgh and London: Nelson, 1959.

Jepsen, Alfred. "'emeth, "Theological Dictionary of the old Testament (1974), 1:313

Johnston, Robert Morris. "Orthodoxy and Heresy in the Biblical Period: Some Reflections on an Elusive Category," 1981. Adventist Heritage Center. James White Library. Andrews University. Berrien Springs, Michigan.

Jones, A. H. M. Were Ancient Heresies Disguised Social Movements?. Philadelphia: Fortrass Press, 1966.

Jones, Rufus M. The Church's Debt to Heretics. New York: George H. Doran Company, 1924.

Justin Martyr First Apology. The Ante-Nicene Fathers. Alexander Roberts and James Donaldson, eds. Grand Rapids, Michigan: Eerdmans, 1956. 1:159-187.

- Dialogue with Tryoho. The Ante-Nicene Fathers. Alexander Roberts and James Donaldson, eds. Grand Rapids, Michigan: Eerdmans, 1956. 1:194-270.

Karrer, Otto. Das zweite Vatikanische Konz1l: Reflexionen zu seiner geschichtlichen und gelstlichen Wirklichkeit. Munich: Köselverlag, 1966.

Kasemann, Ernst. The Testament of Jesus: A Study of the Gospel of John in the Light of Chapter 17. Translated by Gerhard Krodel. Philadelphia: Fortress Press, 1968.

Kelly, J. N. D. Early Christian Doctrines. Rev. ed. San Francisco: Harper \& Row, 1978. 
Kirvan, John J., ed. The Infallibility Debate. New York: Paulist Press, 1971.

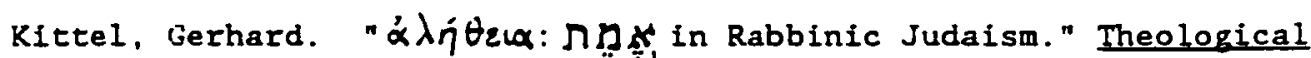
Dictionary of the New Testament. Edited by Gerhard Kittel. Grand Rapids, Michigan: Wm. B. Eerdmans Publishing Co., 1976. $1: \bar{z} \overline{3}$

Kloppenburg, Boaventura. The Ecclesiology of Vatican II, Pp. 169 217. Translated by Matthew J. O'Connel1. Chicago: Franciscan Herali Fress, 1974.

Knox, John. Criticism and Faith. New York: Abingdon-Cokesbury Press, 1952.

Koester, Helmut. "Gnomai Dfaforol. The Origin and Nature of Diversification in the History of Early Christianity." Harvard Theological Review 58 (1965):279-318.

Körner, Stephan. What Is Philosophy?. London: Penguin Press, 1969.

Kraft, Robert A. "The Development of the Concept of 'Orthodoxy' in Early Christianity." In Gerald F. Hawthorne, ed. Current Issues in Biblical and Patristic Interpretation. Studies in Honor of Merril $C$. Tenney Presented by His Former Students. Grand Rapids, Michigan: William B. Eerdmans Publishing Company, 1975.

Krämer, Peter. Dienst und Vollmacht in der Kirche; Efne rechtstheologische Untersuchung zur Sacra Potestas-Lehre des II Vatikanischen Konzl1s. Trierer Theologische Studien 28. Trier: Paulinus-Verlag, 1973.

Krumm, John M. Modern Heresies. Greenwich, Connecticut: Seabury Press, 1961.

Kuhn, Thomas Samuel. The Structure of Scientific Revolutions. 2nd. ed., enl. Chicago: The University of Chicago Press, 1970.

Kümmel, Werner Georg, ed. Introduction to the New Testament. 14th rev. ed. Translated by A. J. Mattill, Jr. Nashville and New York: Abingdon Press, 1966.

Lagrange, Marie-Joseph. Histoire ancienne du canon du Nouveau Testament. Introduction a l'étude du Nouveau Testament, part 1. Paris: J. Gabalda et Cie., 1933.

Lakatos, Imre and Musgrave, Alan, eds. Criticism and the Growth of Knowledge. Cambridge: Cambridge University Press, 1970.

Lambert, Malcolm D. Medieval Heresy: Popular Movements from Bogomil to Hus. London: Edward Arnold Publishers, 1977. 
Lampe, G. W. H. A Patristic Greek Lexicon. Oxford: At The Clarendon Press, 1961-68.

Laurentin, René. Bllan du Concile Vaflean II: Histoire textes, sommentaires. Paris: Editions du Seuil, 1967.

Lindbeck, George A. "A Protestant Point of View." In Vatican II: An Interfaith Aporaisal, Pp. 219-230. Edited by Iohn H. Hiiler. Notre Dame, Indiana: University of Notre Dame Press, 1966.

Le Brun, Jacques. Bossuet, Les écrivains devant Dies. Paris: Desclée De Brouwer, 1970.

Lecler, Joseph, and Valkhoff, Marius-Erançois. Les premiers défenseurs de la liberté religieuse. 2 vols. Paris: Les Editions du Cerf, 1969.

Leff, Gordon. Heresy in the Latter Middle Ages: The Relation of Heterodoxy to Dissent $c, 1250-c, 1450.2$ vols. Manchester: Maschester University Fress, 1967.

Le Goff, Jacques, et al. Hérésies et societés dans l'Europe preindustrielle, 1le, $-18 \mathrm{e}$ siecles. Paris and La Haye: Mouton \& Co., 1968 .

Leicester, Ronald. "Opening Speech." In Authortty and the Church: Papers and Discussions at a Conference Between Theologians of the Church of England and the Gerinan Evange i.ical Church. PP. vif-x. Edited by Ronald Ralph Williams. London: S.P.C.K, 1965.

Lerner, Robert $\mathrm{E}$. The Heresy of the Free Spirit in the Latcer Middle Ages. Berkeley, Los Angeles, and London: University of California Press, 1972.

Lonergan, Bernard J. F. Method in Theolery. New York: Seabury Press, 1972.

Lourdeaux, $w$. and Verhelst, D., eds. The Concept of Heresy in the Middle Azes (1lth-13 th_c.). Louvain, Belgium: Leuven University Press, 1976.

Lynch, C. J. "Franciscans." New Catholic Encyclopedia. 1967 ed. $6: 41$.

Maccarone, M. Rivista da Storia da Chiesa in Italia 3 (1949):309343.

Mackey, J. P. Tradition and Change in the Church. Dayton, Ohio: Pflaum Press, 1968 .

Mackinnon, Edward M. Truth and Expression: The 1968 Hecker Lectures. New York, Paramus, and Toronto: Newman Press, 1971. 
447

Macquarrie, John. "Eschatology and Time." In Moltmann Jürgen, et al. The Fiture of Hope: Theolory as Eschatolory, pp. 110-125. Edlted by Frederick Herzog. New York: Herder and Herder, 1970.

- Thinking about God. New York, Evanston, San Francisco, and London: Harper and Row. Publishers, 1975.

viandeibaum, Maurice. "Historicism." The Fncyclopedia of Philosophy. 1967 ed. 4:22-25.

- The Problem of Historical Knowledge: An Answer to

Relativism. Freeport, New York: Books for Libraries Press, 1938, 1966, reprinted 1971.

Mannheim, Karl. "Historismus." Acchiv für Sozialwissenschaft und Sozialpolitik 52 (1924).

Manschreck, Ilyde L. "Presuppositional Directions for the Problem of Authoricy." Review and Eüpositer 75 (1978):181-193.

Marsha11, I. Howard. "Orthodoxy and Heresy in Earlier Christianity." Themelios 2 (1976):5-14.

Marston, George W. The Voice of Authority. [Nutley, New Jersey]: Presbyterian and Reformed Publishing Company. 1960.

Martelet, Gustave. Les idées maltresses de Vatican II: Initiation à l'esprit du Foncile. Paris: Desclee De Brouwer, 1959.

Martin, Victor. "Comment s'est formée la doctrine de la supériorité du concile sur le pape." Revue des sciences religieuses 17 (1937): $212-43,261-89,404-27$.

Marty, Martin E. "Tübingen Models for Theology." The Christian Century 100 (1983):653-56.

Mascall, E. L. The Recovery of Unity: A Theological Approach. London, New York, and Toronto: Longmans, Green and Co., 1958.

Mazlish, Bruce. The Riddle of History: The Great Sreculators from Vico to Freud. N.p.: Minerva Press, 1966.

McCormick, Richard A. "L'Affaire Curran." America 154 (1986):264267.

McNamara, Kevin, ed. Vaflcan II. The Constitution on the Church, a Theological and Pastoral Commentary. Chicago: Fiantsican Herald Press, i968.

Meinecke, Friedrich. Histortsm: The Rise of a New Historical Outlook. New York: Herder and Herder, 1972. 
Metzger, Bruce M. The Early Versions of the New Testament: The ir crigin. Transmission, and Limitacions. Oxford: Clarendon Press, 1977 .

Miller, Donald E. The Case for Liberal Christianity. San Francisco: hurper añ Row, Publishers, 1381.

Möhler, John Adam. Symbolism: Or Exposifion of the Doctrinal Diffeticuses between Cacholics and Procestants, as Evidenced by The fr Symbolicat Wricings. Translated by James Burton Robertson. New York: Edward Dunigan, 1844.

Meltmann, Jürḡen. Hǚpe and Planning. Translated by Margaret Clarkson. London: S.C.M. Press. New York: Harper \& Row, 1971.

Theolory of Hope: On the Ground and the Implications
Christian Eschatology. New York and Evanston: Harper \& Row,
Publishers, 1967.

Moltmann, Jurgen and Küng, Hans, eds. Who Has the Say in the Church?. Conciltun 148 (August 1981). Edinburgh: T. \& T. Clark; New York: The Seabury Press, 1981.

Moore, R. I. The Birth of Popular Heresy. London: Edward Arnold (Publishers), 1975.

Press, 1977 . The Origins of European Dissent. New York: St. Martin's

Moorhouse, James. Danrers of the Apostolic Age. New York: Thomas Whittaker, 1891 .

Moorman, John. Vatican observed: An Anglican Impression of Vatican II. London: Darton, Longman \& Todd, 1967.

Moule, Charles F. D. The Birth of the New Testament. 3rd. ed. San Francisco: Harper \& Row, Publishers, 1982. 1962 ed. $4: 54$.

Mullins, Edgar Young. Ereedom and Authority in Religion. Philadelphia: Griffith \& Rowland Press, 1913.

Nash, Ronald H., ed. Ideas of History. 2 vols. New York: E. P. Dutton \& Co., 1969.

National Catholic Welfare Conference. Selected Docunents of His Holiness, Pope Pius XII. Washington, D.C.: Merkle Press, n.d. 
No11, Mark A. Between Falth and Criticism: Evangelicals, Scholar. ship, and the Bible in America. San Francisco: Harper \& Row, Publishers, 1986.

O'Brien, John A. The Faith of Milions: The Credentials of the Catholic Religion. Huntington, Indiana: Our Sunday Visitor. 1974.

O'Connor, Daniel J. The Correspondence Theory of Truth. London: Hutchinson \& Co., Publishers, 1975.

Origen Contra Celsus. The Ante-Nicene Fathers. Alexander Roberts and James Donaldson, eds. Grand Rapids, Michigan: Eerdmans, 1956. 4:395-669.

- On First Principles. Translated and edited by G. W. Butterworth. Origen "On Fiest Principles". Introduction by Henrl De Lubac. Gloucester, Massachusetts: Peter Smith, 1973.

Oitlar, Albert C. "A Response." In The Documents of Vatican II, pp. 102-106. Edited by W. M. Abbott. New York: Herder and Herder, 1966.

Packer, J. I. Ereedom, futhority and Scripture. Leicester, England: Inter-Varsity Press, 1982.

Pannenberg, Wolfhart. "Die Aurnahme des philosophischen Gottesbogriffs als dogmatisches Probleme in der früchristlichen Theologie." Zeitschrift für Kirchengeschichte 70 (1959):1-45.

\footnotetext{
"Dogmatic Theses on the Doctrine of Revelation." In Revelation as History, pp. 123-158. Edited by Wolfhart Pannenberg et al. Translated by David Granskou. New York: Macmillan Company; London: Collier-Macmillan, 1968.

- Faith and Reality. Translated by John Maxwell. Philadelphia: Westminster Press, 1977. - Grundfragen systematischer Theologie: Gesammelte Aufsatze. Götingen, 1967.

Paterson, W. P. The Rule of Faith: the Baird Lecture for 1905. London, New York, and Toronto: Hodder and Stoughton, 1912.

Péano, Pierre. "Olieu [Olivi, Pierre Jean]." Dictionnaire de spirttualité. Paris: Beauchesne, 1982. 11:751-62.

Pelikan, Jaroslav. Development of Christian Doctrine: Some Historical Prolegomena. New Haven and London: Yale University Press, 1969.
} 
The Emergence of the Catholic Tradition (100-600). The Cinristian Tradition: A History of the Development of Doctrine Series, vol. 1. Chicago and London: The University of Chicago Press, 1971.

Perkins, Pheme. "Gnosticism as a Christian Heresy." The Encyclopedia of Religion. 1987 ed. $5: 579$.

Peters, Edward, ed. Heresy and Authority in Medieval Euroze, Documents in Translation. Philadelphia: University of Pennsylvania Press, 1980.

Plato Sophist. Tzanslated by Benjamin Jowett. The Dialogues of Plato. Great Books of the Western World, vol. 7. Edited by Robert Maynard Hutchins. Chicago, London, and Toronto: Encyclopaedia Britannica, 1952.

Popper, Karl R. The Poverty of Historlcism. Boston: Beacon Press, 1957.

Prior, A. N. "Correspondence Theory of Truth." The Encyclopedia of Philosophy. 1967 ed. 2:223-232.

Ptolemaeus Ad Floram epistola. J. P. Migne, Patrologiae cursus completus. Serfes graeca. 7,2:1281-1292.

Putnam, Hilary. Reason. Truth and History. Cambridge: Cambridge University Press, 1981 .

Quanbeck, Warren A., ed. Challenge, , and Response: A Protestant Perspective of the Vatican Council. Minneapolis: Augsburg Publishing House, 1966.

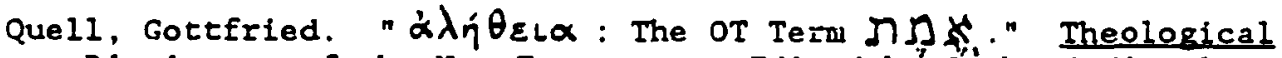
Dictionary of the New Testament. Edited by Gerhard kittel. Grand Rapids, Michigan: Wm. B. Eerdmans Publishing Co.. 1976. $1: 232-235$.

Quesne11, Quentin. The Authority for Authority: The 1969 Pere Marquette Theology Lecture. Milwaukee: Marquette University Theology Departament, 1973.

Quispel, Gilles. Ptolémée, Lettre à Flora: analyse texte crtelque, traduction. commentaire et index grec. Paris: Les Editions du Cerf, 1966.

Rahner, Karl. "The Hierarchical Struvture of the Church, with Special Reference to the Episcopate--Articles 18-27." Translated by Kevin Smyth. In Commentary on the Documents of Vatican II. 5 vols. Edited by Herbert Vorgrimler. London: Burns \& Oates; New York: Herder and Herder, 1967. 1:186-218. 
- Inspiration in the Bible. 2nd, rev. ed. Fribourg:

Herder; London: Burns \& Oates, 1964.

- "Magiscerlum." Sacramentum Mundi. 1969 ed. 3:351-358.

"Observations on the Concept of Revelation." In Karl

Rahner and Josef Ratzinger, Revelation and Tradition. New York:

Herder and Herder, 1966.

. On Heresy. Quaestiones Disputatae. Translated by W. J.

O'Hara. Fribourge Herder; London: Burns \& Oates, 1964.

- Theological Investigations: Volume VI Concerning Vatican

Council II. Translated by Karl-H, and Boniface Kruger.

Baltimore: Helicon Press; London: Darton, Longman \& Todd, 1969.

. "Theology and Anthropology." In T. P. Burke, ed., The Word in History. New York: Sheed \& Ward, 1966.

Rahner, Karl, and Lehmann, Karl. Keryoma and Dogma. Translated by william Glen-Doepel. New York: Herder and Herder, 1969.

Rahner, Karl, and Lehmann, Karl. In Mysterium salutis: Grundriss Heilgeschichtifcher Degmatik. 5 vols. Edited by Johannes Feiner and Magnus Löhrer. Einsiedeln: Benziger Verlag, 1965.

sahrer, Karl, and Schürmann, Heinz. "Kerygma." Lexikon für Theologle und Kirche. 1961 ed. $6: 122-26$.

Ramm, Bernard. The Pattern of Authority. Grand Rapids, Michigan: Wm. B. Eerdmans Publishing Co., 1957.

Ratzinger, Josef. "Primacy, Episcopate, and Apostolic Succession." In The Episcopate and the Primacy, Pp. 37-63. Edited by Karl Rahner and Josef Ratzinger. Translated by Kenneth Barker et al. New York: Herder and Herder, 1963.

Ratzinger, Josef, with Messori, Vittorio. The Ratzinger Report: An Exclusive Interview on the State of the Church. Translated by Salvator Attanasio and Graham Harrison. San Francisco: Ignatius Press, 1985 .

Rawlinson, A. E. J. Authority and Freedom. The Bishop Paddock Lectures for 1923. London, New York, and Toronto: Longmans, Green and Co., 1933.

Refoule, R. F., and P. De Labriolle. Tertullien. "Traité de la prescription contre les hérétiques. Paris: Les Éditions du Cerf, 1957. 
Reiser, William Edward Reiser. "What Calls Forth Heresy?: An Essay on the Development of Dogma within a Heideggerian Concext." Ph.D. dissertation, Vanderbilt University, 1977.

Reschur, Nicholas. The Coherence Theory of Truth. Oxford: At The Clarendon Press, 1973.

Reventlow, Henning Graf. The Authoricy of the Bible and the Rise of the Modern World. Translated by John Bowden. Philadeiphia: Fortress Press, 1985.

Richardson, Alan. A Preface to Bible Study. Philadelphia: Westminster Press, 1944.

Richardson, Cyril C., ed. Early Christian Fathers. New York: Macmillan Publishing Co., 1970.

Riga, Peter J. The Church Renewed. New York: Sheed and Ward, 1966.

Rohinson, James $M$. The Future of Our Religious Past: Essays in Honor of Rudolf Bulemann. London: SCM Press, 1971.

Robinson, James M. and Koester, Helmut. Trajectories through Early Christianity. Philadelphia: Fortress Press, 1971.

Russel1, Bertrand. The Problems of Philosophy. Home Universicy Library of Modern Knowledge Serles, 35. New York: Henry Holt and Coupany; Londion: Thornton Butterworth, n.d.

Russel1, Jeffrey Burton. Dissent and Reform in the Early Middle Ages. Berkeley and Los Angeles: University of California Press, 1965.

ed. Religious Dissent in the Middle ires. New York, London, Sydney, and Toronto: John Wiley \& Sons, 1971.

Ryan, Michael D. The Contemporary Explosion af Theoleoy: Lanfion Gilkey. Hans Kung. Teilhard de Chardin. Metuchen, New Jersey: Scarecrow Press, 1975.

Ryan, Seamus. "The Hierarchical Structure of the Church." In Vatican II: The constitution on the Church: A Theologiral and Pastoral Commentary, pp. 199-211. Edited by Kevin McNamara. Chicago: Franciscan Herald Press, 1968.

Rynne, Xavier. Vatican Council II. New York: Farrar, Straus and Giroux, 1968 .

Sabatier, Auguste. Qutlines of a Philosophy of Religion Based on Psychology and History. Translated by T. A. Seed. London: Hodder and Stoughton, 1902. 
Religions of Authortty and the Religion of the Spirit.

New York: McClure, Phillips \& Co., 1905.

. The Religions of Authority and the Religions of the

Splrit. London and New York: Williams and Norgate, 1910.

Scharlemann, Robert P. The Being of God: Theology and the

Experience of Truth. New York: Seabury Press, 1981.

Schillebeeckx, Edward. Christ: The Christlan Experience in the Modem World. Translaced by John Bowden. London: SCM Press, 1980.

- Jesus: An Expertment in Christology. Translated by Hubert Hoskins. London: Collins, 1979.

The Real Achlevement of Vacican II. Translated by $H . J$. J. Vaughan. New York: Herder and Herder, 1967.

Schleiermacher, Frederich. The Christian Faith. New York: Harper Torchbooks, 1963.

Schnelder, Hans. Der Konzillarismus als Problem der Neueren Katholischen Theolegie: Die Geschichte der Ausleoung der Konstanzer Dekrete von Febronius bis zur Gerenwart, Arbeiten zur Kirchengeschichte 47. Berlin and New York: Walter De Gruyter, 1976.

Schoof, T. Mark, O.P. A Survey of Cacholic Theology: 1800-1970. Translated by N. D. Smith. Glen Rock, New Jersey: Paulist Newman Press, 1970.

Schultz, Hans Jürgen. Die Wahrhe1t der Ketzer. Berlin and Stuttgart: Kreuz-Verlag, 1968.

Schweizer, Eduard. The Guod News According to Mark. Translated by Donald H. Madvig. Rintwund, Virginia: John Knox Press, 1970.

- Luke. A Challenge to Present Theolegy. Atlanta: John Knox Press, 1982 .

Schwital, Johannes. Grosskirche und Sekte: Eine Studie zum Selbstverstandnis der sekte. Hamburg: Saatkorn-Verlag, 1962.

Scott, Robert B. Y. Proverbs-Ecclesiastes. Anchor Bible. Vol. 18. Garden City, New York: Doubleday \& Company, 1965.

Serapion Libro de Evangelio Petri fragmenta. J.-P. Migne, patrologiae cursus complecus, Serles graeca. 5:1373-1376. 
Shelley, Bruce. By what Authority? The Standards of Truth in the Early Church. Grand Rapids, Michigan: William B. Eerdmans Publishing Company, 1965.

Sider, Ronald J., ed. The Chicago Declaration. Carol stream, IIlinois: Creation House, 1974.

Simons, Eberhard. "Kerygma." Sacramentum Mundi. 1969 ed. 3:245248.

Skydsgaard, Kristen E. "The Church as Mystery and as People of God." In George A. Lindbeck, ed. Dialogue on the Way: Protes tants Report from Rome on the Vatican Councii, Pp. 145-174. Minneapolis: Augsburg Publishing House, 1965.

Sc:i:=z, Alcainder. The Text and Canon of the New Testament. 2nd. ed. Revised by C. S. C. Williams. London: Gerald Duckworth \& Co., 1954 .

Steck, Karl Gerhard, Die christliche Wahrheit zwischen Haresie und Konfession. Munich: Chr. Kaiser Verlag, 1974.

Stone, Michael Edward. Scriptures. Sects and Visions: A Profile of Judaism from Ezra to the Jewish Revolts. Philadelphia: Fortress Press, 1980 .

Stover, Robert. The Nature of Historical Thinking. Chapel Hill, North Carolina: University of North Carolina Press, 1967.

Stumpf, Samuel Enoch. Socrates to Sartre: A History of Philosophy. New York: McGraw-Hill Book Company, 1982.

Subilia, Vittcrio. La nouva cattolicità del Cattolicesimo: Una valutazione protestante del Concilio Vaticano II. Torino: Editrice Claudiana, 1967.

Sullivan, Francis A. Magisteriumi Teaching Authority in the Catholfc Church. New York: Paulist Press, 1983.

Tavard, George H., A.A. De Divina Revelatione: The Dogmatic Constitution on Divine Revglacion of Vatican Council II. Glen Rock, New Jersey: Vatican II Documents, Paulist Press, 1966.

- Holy Writ or Holy Church: The Crisis of the Protestant Reformation. New York: Harper and Brothers, Publishers, 1959.

Tertullian De Praescriptione haereticorum. The Ante-Nicene Fathers. Alexander Roberts and James Donaldson, eds. Grand Rapids, Michigan: Eerdmans, 1957. 3:243-265. 
De Virginibus velandis. The Ante-Nicene Fachers. Alexander Roberts and James Donaldson, eds. Grand Rapids. Michigan: Eerdmans, 1956. 4:27-37.

- Adversus Praxeam. The Ante-Nicene Fathers, Alexander Roberts and James Donaldson, eds. Grand Rapids, Michigan: Eerdmans, 1957. 3:597-628.

- Contra Marcion. The Ante-Nicene Fathers. Alexander Roberts and James Donaldson, eds. Grand Rapids, Michigan: Eerdmans, $1957.3: 271-474$.

Thiselton, Anthony C. "Truth." New International Dictionary of New Testament Theology. Edited by Colin Brown. Grand Rapids, Michigan: Zondervan Publishing House, 1986. 3:874-901.

Thouzellier, Christine. Hérésje et hérétiques: Vaudois, Cathares, Patarins. Albigeois. Rome: Edizioni di Storia e Letteratura. 1969 .

Tierney, Brian. Foundations of the Concillar Theory: The Contribution of the Medieval Canonists from Gratian to the Great Schism. Cambridge: At The University Press, 1955.

- Origins of Papal Infallibility, 1150-1350: A Study on the Concepts of Infallibility. Sovereignty and Tradition in the Middle Ares. Leiden, Netherlands: Brill, 1972.

Tillinghast, Pardon E. Approaches to History: Selections in the Philosophy of History from the Greeks to Hegel. Englewood Cliffs, New Jersey: Prentice-Hall, 1963.

Tillich, Paul. The Interpretation of History. Translated by N. A. Rasetzki and Elsa L. Talmey. New York and London: Charles Scribner's Sons, 1936.

Todd, John M., ed. Problems of Authority. Baltimore: Helicon Press, 1964.

Torrance, Thomas F. "Truth and Authority: Theses on Truth." Irish Theological Quarterly 39 (1972):215-242.

Troeltsch, Ernst. Der Historismus und seine Probleme. Tübingen: $C$. B. Mohr, 1922 .

Turner, Henry E. W. The Patreen of Chrisian Truth: A Study in the Relations between Orthodoxy and Heresy in the Early Church. Bampton Lectures 1954. London: A. R. Mowbray \& Co., 1954. 
Twomey, Vincent. Apostolikos Thronos: The Primacy of Rome as

Reflected in The Church History of Eusebius and the HistoricoApologetic Writings of St. Athanasius the Great. Münster, West Germany: Aschendorff Münster, 1982.

Van Dusen, Henry P. The Vindication of Liberal Theology: A Iract for the Times. New York: Charles Scribner's Sons, 1963.

Vawter, Bruce. Blblical Inspiration. Philadelphia: Westminster; London: Hutchinson, 1972.

Villiger, Johann Baptist. "Schism: Western Schism." Sacramentum Mundi. 1970 ed. $6: 16-19$.

Vincent of Léri:s Commonitorium primum. J.-P. Migne, Patrologiae cursus completus. Series latina. 50:637-678.

Vorgrimler, Herbert. Understanding Karl Rahner: An Introduction To His Life and Thought. Translated by John Bowden. New York: Crossroad, 1986.

Vos, Geerhardus. "'True' and 'Truch' in the Johannine Writings." In Redemptive History and Biblical Interpretation: The Shorter Writings of Geerhardus Vos. Edited by Richard B. Gaffin, Jr. Phillipsbirg, New Jersey: Presbyterian and Reformed Publishing Co., 1980 .

Wakefield, Walter L. Heresies of the High Middle Ages; Selected Sources Translated and Annotated. New York and London: Columbia University Press, 1969.

Walgrave, Jan Hendrik. Unfolding Revelation: The Nature of Doctrine Development. London: Hutchinson; Philadelphia: Westminster, 1972.

Weber, N. A. "Nicholas III." The Cacholic Encyclopedia. $1911 \mathrm{ed}$. $11: 56-57$.

Weischedel, Wilhelm. "Was heisst Wirklichkeit?" In restschrift für Enst Fuchs. Edited by G. Ebeling, E. Jügel, and G. Schunack. Tubingen: n.p., 1973.

Welter, G. Histoire des sectes chrétiennes des origines à nos jeurs. Paris: Payot, 1950.

White, Alan R. Truth. Problems in Philosophy Series. Garden City, New York: Anchor Books, Doubleday \& Co., 1970.

White, Ellen G. Counsels to Writers and Editors. Nashville, Tennessee: Southern Publishing Association, 1946. 
W'Ies, Maurice. The Making of Christian Doctrine: A Study in the Principles of Early Doctrinal Development. Cambridge: At the University Press, 1967.

Wilken, Robert L. The Myth of Christlan Beginnings: History's Impact on Belief. Garden City, New York: Doubleday, 1971.

Williams, Christopher J. F. What Is Iruth?. Cambridge: Cambridge University Press, 1976.

Williams, Cornelius. "The Church Is Hierarchical, Commentary on Chapter Three." In Vatican II on The Church, Pp. 46-61. Edited by Austin Flannery. Dublin: Scepter Books, 1967.

Williams, R. R. Authority in int Apostolic Age. London: SCM Press, 1950 .

Wojtyla, Karol (Pope John Paul II). Sources of Renewal: The Implementation of the Second Vatican Council. Translated by $P$. S. Falla. San Francisco: Harper \& Row, Publishers. 1979.

Xiberta, Bartholomaeus M. Guidonis Terrent quaestio de magisterio infallibili Romani pontificis, opuscula et textis. Series scholastica et mystica, fasc. 2. Münster, West Germany: Aschendorff, 1926 .

Yardeni, Myriam, ed. Modernité et non-conformisme en France à travers les ages. Leiden, Netherlands: E. J. Brill, 1983.

Yarnold, Greville Dennis. By What Authority? Studies in the Relations of Scripture. Church, and Ministry. London: A. R. Mowbray \& Co., 1964.

Zahn, Theodor. "Canon of Scripture." The New Schaff-Herzog Encyclopedia of Religious Knowledge. 1908 ed. 2:388-400.

"Muratorian Canon." The New Schaff-Herzor Encyciopedia of Religious Knowledge. 1910 ed. 8:53-56.

Zdrodowski, Francis J. The Concept of Heresy According to Cardinal Hosius. Washington, D. C.: The Catholic University of America Press, 1947. 